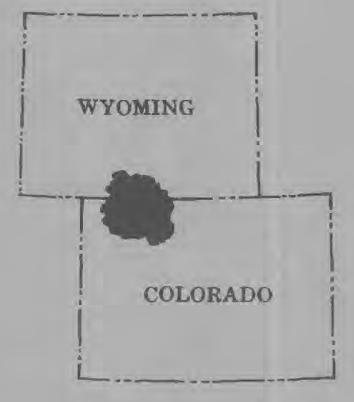

UNITED STATES

DEPARTMENT OF THE INTERIOR

GEOLOGICAL SURVEY

\title{
ANALYSIS OF STREAM QUALITY IN THE YAMPA RIVER BASIN, COLORADO AND WYOMING
}

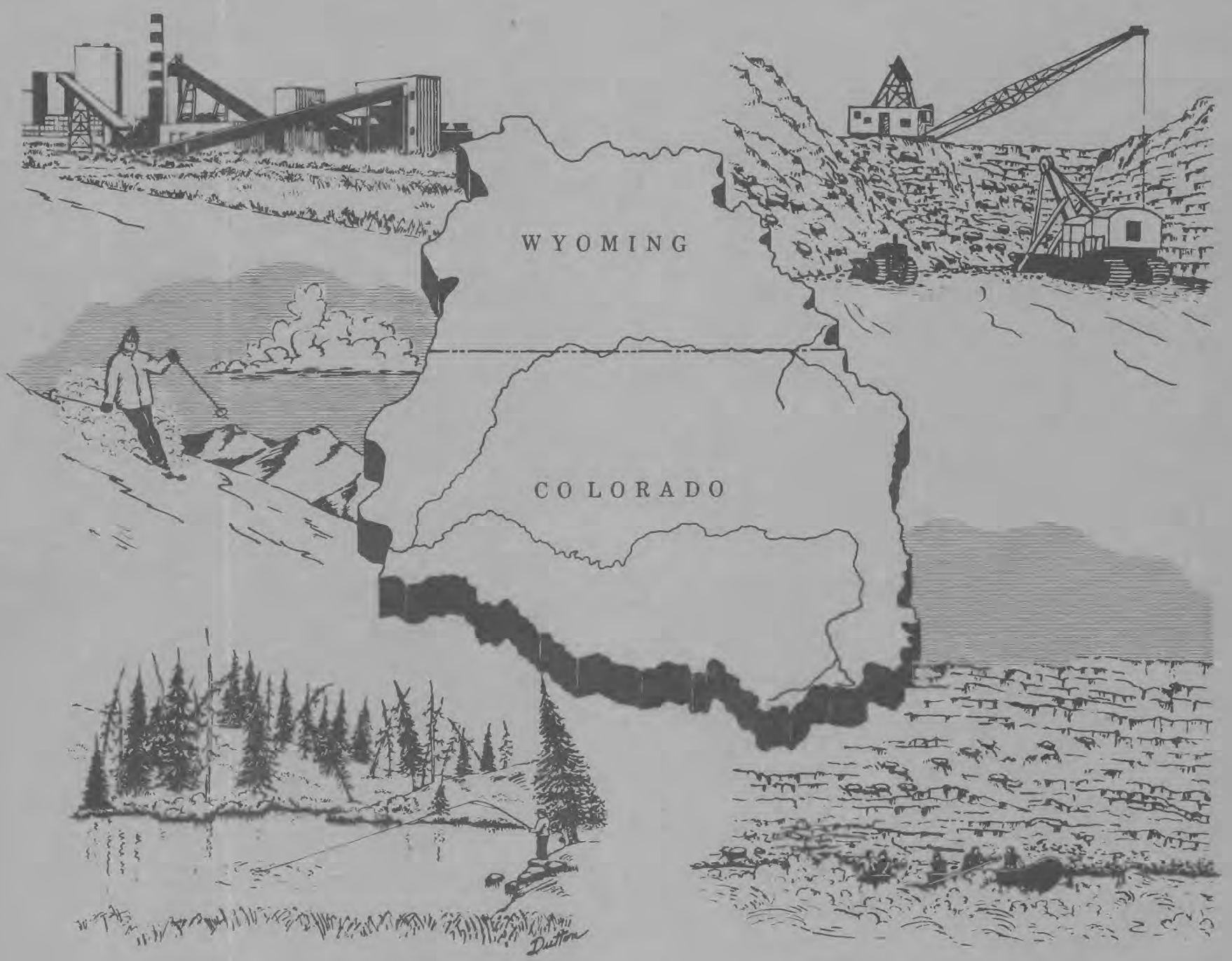




\begin{tabular}{|c|c|c|}
\hline $\begin{array}{l}\text { REPORT DOCUMENTATION } \\
\text { PAGE }\end{array}$ & 1. REPORT NO. & 3. Recipient's Accession No. \\
\hline \multirow{2}{*}{\multicolumn{2}{|c|}{$\begin{array}{l}\text { 4. Title and subtitle } \\
\text { ANALYSIS OF STREAM QUALITY IN THE YAMPA RIVER BASIN, } \\
\text { COLORADO AND WYOMING }\end{array}$}} & $\begin{array}{l}\text { 5. Report Date } \\
\text { Apr i } 11980\end{array}$ \\
\hline & & \multirow{2}{*}{$\begin{array}{l}\text { 6. Performing Organization Rept. No. } \\
\text { USGS/WRI } 30-08\end{array}$} \\
\hline 7. Aythor(s) & d Timothy Doak Steele & \\
\hline \multirow{2}{*}{\multicolumn{2}{|c|}{$\begin{array}{l}\text { 9. Performing Organization Name and Address } \\
\text { U.S. Geological Survey, Water Resources Division } \\
\text { Box } 25046 \text {, Denver Federal Center, Mail Stop } 415 \\
\text { Lakewood, c0 } 80225\end{array}$}} & 10. Project/Task/Work Unit No. \\
\hline & & $\begin{array}{l}\text { 11. Contract(C) or Grant(G) No. } \\
\text { (C) }\end{array}$ \\
\hline \multirow{2}{*}{\multicolumn{2}{|c|}{$\begin{array}{l}\text { 12. Sponsoring Organization Name and Address } \\
\text { U.S. Geological Survey, Water Resources Division } \\
\text { Box 25046, Denver Federal Center, Mail Stop } 415 \\
\text { Lakewood, c0 } 80225\end{array}$}} & 13. Type of Report \& Period Covered \\
\hline & & 14. \\
\hline
\end{tabular}

15. Supplementary Notes

16. Abstract (Limit: 200 words) Historic data show no significant water-temperature changes since 1951 for the Little Snake or Yampa Rivers, the two major streams of the Yampa River basin. Regional analyses indicate that harmonic-mean temperature is negatively correlated with altitude. Ho change in specific conductance since 1951 was noted for the Little Snake River; however, specific conductance in the Yampa River has increased 14 percent since that time and is attributed to increased agricultural and municipal use of water. Site-specific relationships between major inorganic constituents and specific conductance for the Little Snake and Yampa Rivers were similar to regional relationships developed from both historic and recent (1975) data. These relationships provide a means for estimating concentrations of major inorganic constituents from specific conductance, which is easily measured.

Trace-element and nutrient data collected from August 1975 through September 1976 at 92 sites in the Yampa River basin indicate that water-quality degradation occurred upstream from 3 sites. The degradation resulted from underground drainage from pyritic materials that probably are associated with coal at one site, discharge from powerplant cooling-tower blowdown water at a second site, and runoff from a small watershed containing a gas field at the third site. Ambient concentrations of dissolved and total iron and manganese frequently exceeded proposed Colorado water-quality standards. The concentrations of many dissolved and total trace elements and nutrients were greatest during March 1976. These were associated with larger suspended-sediment concentrations and smaller pH values than at other $t$ imes of the year.

17. Document Analysis a. Descriptors

Water quality, Water chemistry, Water-resources development, Regional analysis, Chemical analysis, Hydrologic data, Statistical methods, Regression analysis, Time-series analysis, Colorado, Wyoming, Computer programs, Surface water, Irrigation.

b. Identifiers/Open-Ended Terms

Yampa River basin (Colo.-Wyo.), Water quality-streamflow relationships, Harmonic analysis, Frequency distribution

c. COSATI Field/Group

18. Availability Statement

Ho restriction on distribution

\begin{tabular}{|l} 
19. Security Class (This Report) \\
UNCLASS I F I ED \\
\hline $\begin{array}{l}\text { 20. Security Class (This Page) } \\
\text { UNCLASS I F IED }\end{array}$ \\
\hline
\end{tabular}


ANALYSIS OF STREAM QUALITY IN THE

YAMPA RIVER BASIN, COLORADO AND WYOMING

By Dennis A. Wentz and Timothy Doak Steele

\section{U.S. GEOLOGICAL SURVEY}

Water-Resources Investigations 80-8

Lakewood, Colorado 


\section{U.S. DEPARTMENT OF THE INTERIOR \\ CECIL D. ANDRUS, Secretary}

GEOLOGICAL SURVEY

H. William Menard, Director

For additional information write to:

District Chief

U.S. Geological Survey

Box 25046, Mail Stop 415

Denver Federal Center

Lakewood, CO 80225 


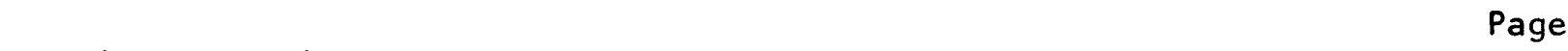

Metric conversion table. . . . . . . . . . . . . . . . . . . VIII

Abstract . . . . . . . . . . . . . . . . . . . . . . 1

Introduction . . . . . . . . . . . . . . . . . . . . . . . . 1

Approach . . . . . . . . . . . . . . . . . . . . . . 3

Historic data... . . . . . . . . . . . . . . . . . . . 4 4

Basinwide reconnaissance--1975. . . . . . . . . . . . . . . . 5

Quarterly sampling program--1975 to 1976. . . . . . . . . . . 5

Related studies..... . . . . . . . . . . . . . . 5

Results and discussion... . . . . . . . . . . . . . . . 10

Stream temperature. . . . . . . . . . . . . . . . . . . 10

Major inorganic constituents and specific conductance... . . . . 26

Stream quality during low flow. . . . . . . . . . . . . . . 40

Trace elements and $\mathrm{pH}$. . . . . . . . . . . . . . . 40

Nutrients. . . . . . . . . . . . . . . . . . . 67

Dissolved oxygen . . . . . . . . . . . . . . . . . 68

Biology. . . . . . . . . . . . . . . . . . . . 68

Ambient stream quality. . . . . . . . . . . . . . 75

Seasonal variations in stream quality. . . . . . . . . . . . 75

Frequency distributions. . . . . . . . . . . . . . . 78

Outlier analys is... . . . . . . . . . . . . . . 95

Changes in ambient stream quality. . . . . . . . . . . . 99

Toxic organic and radiochemical constituents . . . . . . . . 99

Effects of coal mining on stream quality. . . . . . . . . . . 102

Summary. . . . . . . . . . . . . . . . . . . . . . . . 104

References cited . . . . . . . . . . . . . . . . . . . . . . 106

Supplemental information . . . . . . . . . . . . . . . . . . . 111

Stream quality during low flow. . . . . . . . . . . . . . . . 111

Precision of chemical-constituent concentrations . . . . . . . 111

Trace elements in water. . . . . . . . . . . . . . . 113

Trace elements in stream-bottom sediments. . . . . . . . . . . 119

Nutrients. . . . . . . . . . . . . . . . . . . . 123

Seasonal variations in stream quality . . . . . . . . . . . . . 127

Trace elements in water. . . . . . . . . . . . . . . 127

Trace elements in stream-bottom sediments. . . . . . . . . 145

Nutrients. . . . . . . . . . . . . . . . . . . 153

Calculation of evaporative-cooling concentration factor . . . . . 161 


\section{ILLUSTRATIONS}

Figure 1. Map of the Yampa River basin showing location of sampling

Page

$$
\text { sites..................... } 2
$$

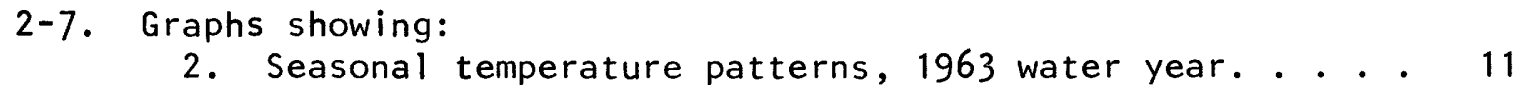

3. Diel variation of stream temperature at selected sites along the Yampa River, September 23-24, 1975. . . . 15

4. Relationships between stream-temperature harmonicanalysis coefficients and altitude for streams in the Yampa River basin, 1960-75. . . . . . . . . .

5. Observed and simulated annual mean discharge-weighted dissolved-solids concentrations, Yampa River near

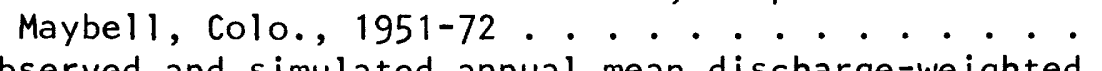

6. Observed and simulated annual mean discharge-weighted calcium concentrations, Yampa River near Maybell, Colo., 1951-72. . . . . . . . . . . . .

7. Observed and simulated annual mean discharge-weighted dissolved-solids concentrations, Little Snake River near Lily, Colo., 1951-69 . . . . . . . . . . . .

8. Map showing location of stream sites where samples for analy-

sis of major inorganic constituents were collected during

the basinwide reconnaissance, August-September 1975 . . . 34

9-16. Graphs showing:

9. Specific conductance in the Yampa and Little Snake Rivers, August-September 1975 and August 1976 . . .

10. Seasonal patterns of streamflow and specific conductance, Yampa River below diversion near Hayden, Colo. (site Y-47), August 1975-September 1976..... 38

11. Streamflow and specific conductance, Yampa River at Steamboat Springs, Colo. (site Y-64), April-September 1977. . . . . . . . . . . . . . . . .

12. Relationships between streamflow and specific conductance during low flow and snowmelt runoff, Yampa River at Steamboat Springs, Colo. (site Y-64), AprilSeptember 1977.

13. Frequency distributions of specific conductance in streams of the Yampa River basin, August-September 1975 through August-September 1976. . . . . . . . . .

14. Frequency distributions of total selenium and dissolved copper in streams of the Yampa River basin, AugustSeptember 1975. . . . . . . . . . . . • • . .

15. Probability plots of total zinc in streams of the Yampa River basin, August-September 1975. . . . . . . 4 


\section{CONTENTS}

Figures 17-19. Maps showing:

17. Sites where dissolved and total trace-element concentrations in streamflow indicate upstream sources of water-quality degradation in the Yampa River basin, August-September 1975. . . .

18. Sites where iron concentrations in streamflow exceeded the water-supply standard, AugustSeptember 1975. . . . . . . . . . . . . .

19. Sites where mançanese concentrations in streamflow exceeded the water-supply standard, August-September 1975 . . . . . . . . . . . .

20. Graph showing stream-reach profiles of total- and dissolved-iron concentrations, August-September 1975. . . 56

21. Map showing sites where mercury concentrations in streamflow exceeded the aquatic-life standard, AugustSeptember 1975 . . . . . . . . . . . . . . 58

22-80. Graphs showing:

22. Diel variation of stream $\mathrm{pH}$ at selected sites along the Yampa River, September 23-24, 1975.

23. Frequency distributions of iron and chromium in stream-bottom sediments of the Yampa River basin, August-September 1975. . . . . . . .

24. Relationships between iron in suspended and stream-bottom sediments of the Yampa River

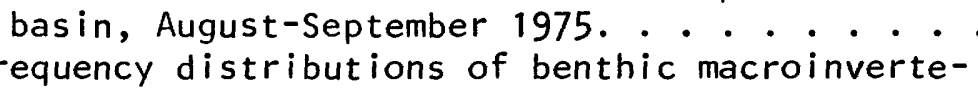

25. Frequency distributions of benthic macroinver
brates in streams of the Yampa River basin, August-September 1975 . . . . . . . . . .

26. Stream-reach profiles of benthic macroinvertebrates in the Yampa River, August-September 1975. . . . . . . . . . . . . . . .

requency distributions of periphyton in streams of the Yampa River basin, August-September 1975

28-41. Frequency distributions, Yampa River basin, August-September 1975 through August-September 1976, of :

28. Total mercury in streams... . . . . 80

29. Dissolved cadmium in streams...... 81

30. Total manganese in streams . . . . . 82

31. Dissolved lead in streams. . . . . . 83

32. Total iron in streams. . . . . . . . 84

33. Dissolved vanadium in streams. . . . . 85

34. Suspended sediment in streams. . . . . 86

35. $\mathrm{pH}$ in streams. . . . . . . . . . . 87

36. Arsenic in stream-bottom sediments.. . 91

37. Copper in stream-bottom sediments. . . . 92

38. Total Kjeldahl nitrogen in streams . . 93 


\section{CONTENTS}

Figures 22-80. Graphs--Continued

Page

28-41. Frequency distributions, Yampa River basin,

August-September 1975 through August-

September 1976, of--Continued

39. Dissolved organic carbon in streams. 94

40. Dissolved oxygen in streams .... . 96

41. Water temperature in streams. . . . 97

42-49. Frequency distributions, Yampa River basin,

August-September 1975, of:

42. Cadmium, cobalt, and copper in streams . . . . . . . . . . 114

43. I ron and lead in streams. . . . . 115

44. Manganese and mercury in streams. . 116

45. Nickel, selenium, vanadium, and zinc in streams. . . . . . . . . . . . . 117

46. Antimony, arsenic, chromium, and copper in stream-bottom sediments. . 120

47. Iron, lead, mercury, and nickel in stream-bottom sediments . . . . 121

48. Nitrogen in streams ...... . . . 124

49. Organic carbon and of phosphorus in streams ............ 125

50-80. Frequency distributions, Yampa River basin, August-September 1975 through AugustSeptember 1976, of:

50. Dissolved and total antimony in streams ........... 128

51. Dissolved arsenic in streams. ... 129

52. Total arsenic in streams. . . . . 130

53. Dissolved and total cadmium in streams ............ . 131

54. Dissolved and total cobalt in streams 132

55. Dissolved and total copper in streams 133

56. Dissolved iron in streams . . . . 134

57. Total iron in streams . . . . . . 135

58. Dissolved and total lead in streams. 136

59. Dissolved manganese in streams. . . 137

60. Total manganese in streams. . . . 138

61. Dissolved and total mercury in streams .......... . 139

62. Dissolved and total nickel in streams 140

63. Dissolved selenium in streams ... 141

64. Total selenium in streams ..... 142

65. Dissolved vanadium in streams .... 143

66. Dissolved and total zinc in streams. 144

67. Antimony in stream-bottom sediments . 146

68. Arsenic in stream-bottom sediments. . 147 


\section{CONTENTS}

Figures 22-80. Graphs--Continued

Page

50-80. Frequency distributions, Yampa River basin, August-September 1975 through August-

September 1976, of--Cont inued

69. Chromium in stream-bottom sediments. 148

70. Copper in stream-bottom sediments.. 149

71. I ron in stream-bottom sediments . . 150

72. Mercury in stream-bottom sediments. 151

73. Nickel in stream-bottom sediments . 152

74. Dissolved Kjeldahl nitrogen in streams ........... . 154

75. Total Kjeldahl nitrogen in streams. 155

76. Dissolved nitrite plus nitrate in streams . . . . . . . . . 156

77. Total nitrite plus nitrate in streams 157

78. Dissolved and dissolved plus suspended organic carbon in streams. . . 158

79. Dissolved phosphorus in streams .. . 159

80. Total phosphorus in streams .... 160

\section{TABLES}

Table 1. Description of sampling sites in the Yampa River basin. . .

2. Harmonic analysis of daily stream temperatures in the Yampa River basin . . . . . . . . . . . . . . .

3. Harmonic analysis of daily minimum and maximum stream temperatures near station 09244410, Yampa River below diversion, near Hayden, Colo. (near site Y-47), March 10 to Decem-

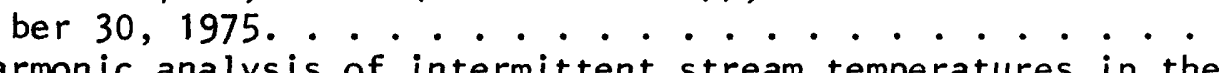

4. Harmonic analysis of intermittent stream temperatures in the Yampa River basin, 1960-75. . . . . . . . . . 18

5. Water-quality standards for water use in Colorado ...... 22

6. Regional regression relationships for major inorganic constituents in streams of the Yampa River basin, as computed from historic data. . . . . . . . . . . . . . .

7. Site-specific regression relationships for major inorganic constituents in streams of the Yampa River basin. . . . .

8. Regional regression relationships for major inorganic constituents in streams of the Yampa River basin, as computed from data collected during the basinwide reconnaissance, August-September 1975 . . . . . . . . . . . .

9. Number of sites where trace-element concentrations and $\mathrm{pH}$ in streamflow did not meet water-supply, aquatic-life, and agricultural standards, Yampa River basin, August-September 1975. 


\section{CONTENTS}

Table 10. Possible relationships between trace elements in stream sediments and in water, Yampa River basin, August-September 1975. . . . . . . . . . . . . . . . . . 65

11. Possible relationships between trace elements in streambottom sediments, Yampa River basin, August-September 1975. 66

12. Comparison of benthic-macroinvertebrate data collected from the Yampa River during August-September 1975 and data reported by Eddy (1975) . . . . . . . . . . . . . . .

Page

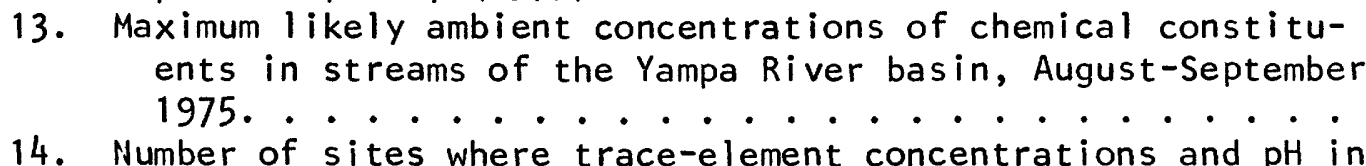

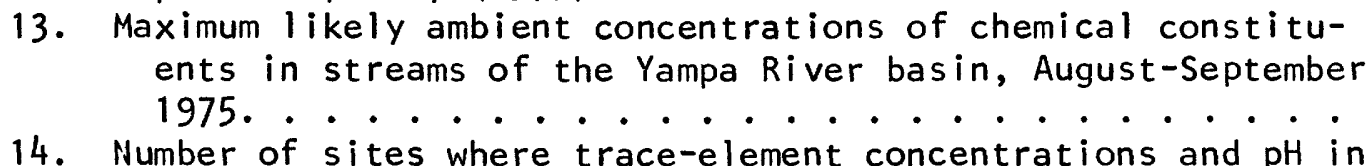

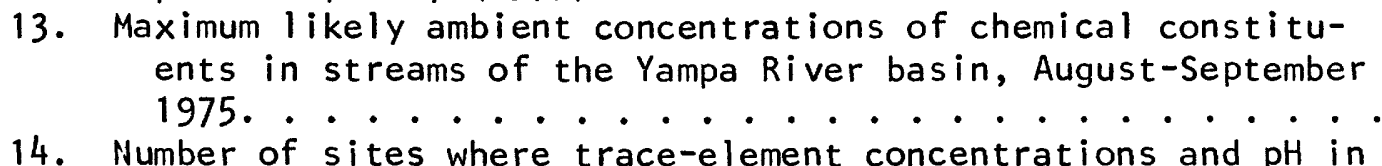
streamflow did not meet water-supply, aquatic-life, and agricultural standards, Yampa River basin, December 1975 through August-September 1976 ........... . . .

15. Results of outlier analysis, Yampa River basin, December 1975 through August-September 1976 . . . . . . . . . .

16. Seasonal changes in maximum likely ambient concentrations of chemical constituents in streams of the Yampa River basin, December 1975 to August-September 1976. . . . • . . . .

17. Precision of chemical-constituent concentrations in streams
of the Yampa River basin, August-September 1975....

17. Precision of chemical-constituent concentrations in streams
of the Yampa River basin, August-September 1975 . . .

\section{METRIC CONVERSION TABLE}

The units in the inch-pound system used in this report may be converted to metric units by the following conversion factors:

To convert inch-pound unit

cubic foot per second $\left(\mathrm{ft}^{3} / \mathrm{s}\right)$

foot $(f t)$

mile $(\mathrm{mi})$

square mile $\left(m i^{2}\right)$

ton (short)

gallon per minute (gal/min)
Multiply by

0.02832

0.3048

1.609

2.590

0.9072

0.06309
To obtain metric unit

cubic meter per second $\left(\mathrm{m}^{3} / \mathrm{s}\right)$ meter ( $m$ )

kilometer $(\mathrm{km})$

square kilometer $\left(\mathrm{km}^{2}\right)$

metric ton $(t)$

liter per second (L/S) 


\section{ANALYSIS OF STREAM QUALITY IN THE YAMPA RIVER BASIN, COLORADO AND WYOMING}

By Dennis A. Wentz and Timothy Doak Steele

\section{ABSTRACT}

Historic data show no significant water-temperature changes since 1951 for the Little Snake River or the Yampa River, the two major streams of the Yampa River basin. Regional analyses indicate that harmonic-mean temperature is negatively correlated with altitude, thus allowing stream temperatures to be estimated at unmeasured sites in the basin. No change in specific conductance since 1951 was noted for the Little Snake River; however, specific conductance in the Yampa River has increased 14 percent since that time and is attributed to increased agricultural and municipal use of water. Sitespecific relationships between major inorganic constituents and specific conductance for the Little Snake and the Yampa Rivers were similar to regional relationships developed for the entire basin from both historic and recent (1975) data. These relationships provide a means for estimating concentrations of major inorganic constituents from specific conductance, which is easily measured.

Trace-element and nutrient data collected from August 1975 through September 1976 at 92 sites in the Yampa River basin indicate that waterquality degradation occurred upstream from 3 sites. The degradation resulted from underground drainage from pyritic materials that probably are associated with coal at one site, discharge from powerplant cooling-tower blowdown water at a second site, and runoff from a small watershed containing a gas field at the third site. In the latter instance, it is not known if the effect was natural or man-induced. Although not critical problems, ambient concentrations of dissolved and total iron and manganese frequently exceeded proposed Colorado water-quality standards. The concentrations of many dissolved and total trace elements and nutrients were greatest during March 1976 . These trace-element and nutrient concentrations were associated with relatively larger suspended-sediment concentrations and relatively smaller pH values than occurred at other times of the year. Seasonal fluctuations in specific conductance were controlled primarily by and were inversely related to stream discharge.

\section{INTRODUCTION}

Energy resources, primarily coal, are being developed at increasing rates in the $8,080-\mathrm{mi}^{2}\left(20,900-\mathrm{km}^{2}\right)$ Yampa River basin of northwestern Colorado and south-central Wyoming (fig. 1). For example, annual coal production 


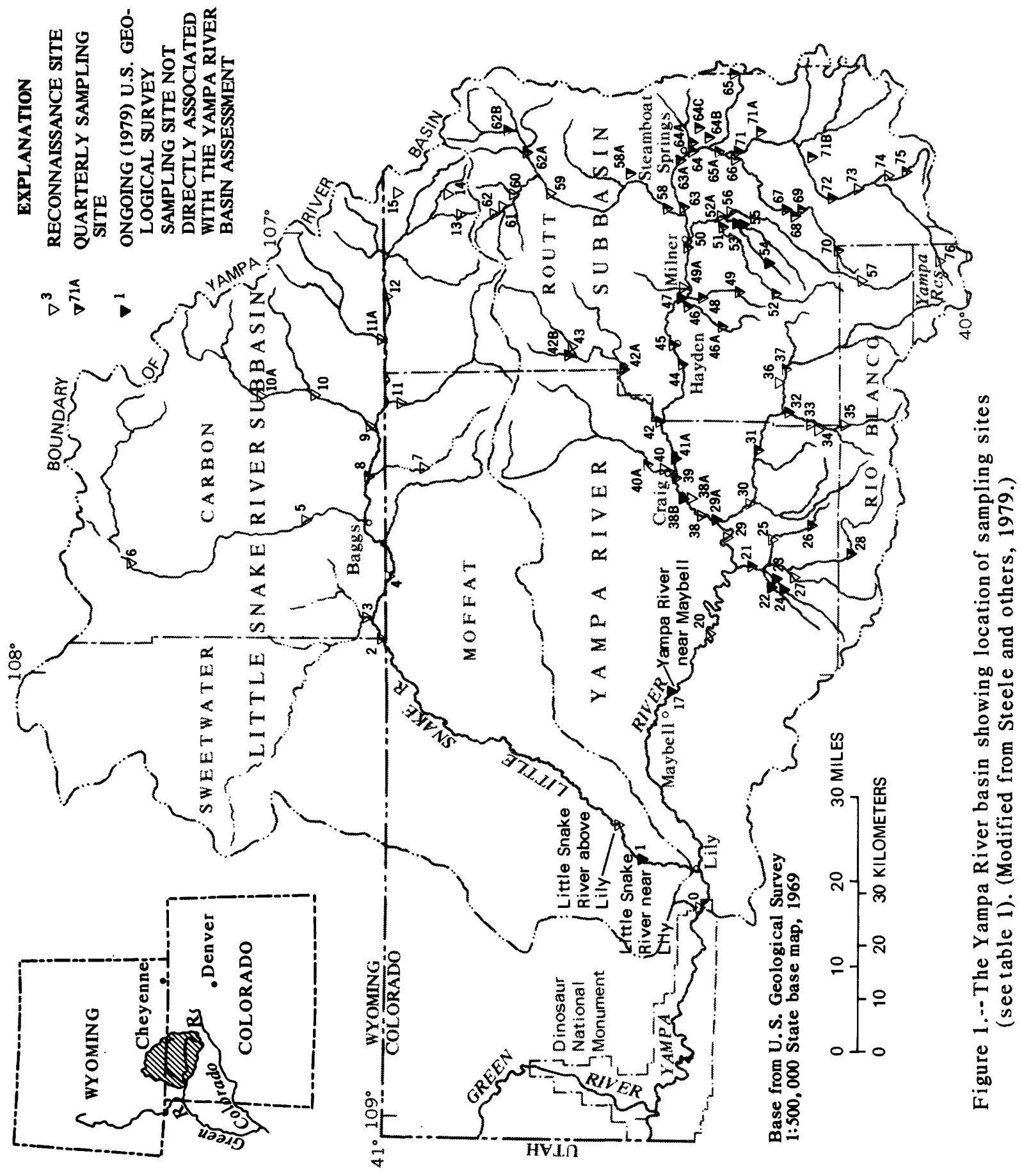


in northwestern Colorado was $4.6 \mathrm{million}$ tons $(4.2 \mathrm{million} \mathrm{t}$ ) in 1975 when this study was begun. Production is expected to increase from more than $9.4 \mathrm{million}$ tons $(8.9 \mathrm{million} \mathrm{t})$ in 1978 to more than $20 \mathrm{million}$ tons (18 million $t)$ by 1990. Other energy resources in the basin include oil and gas, oil shale, uranium, and geothermal springs; however, all but oil and gas are relatively unimportant in economic terms compared to the basin's coal reserves.

Various plans for development of coal resources in the bas in were described initially by Steele (1976) but have been modified substantially (Udis and others, 1977; Steele and others, 1979). The anticipated coal-resource development will affect environmental quality by contributing increased discharges of wastes to air, water, and land. Attempts to modify or reduce the waste discharges will affect both the quantity and quality of the basin's water resources.

The Yampa River basin assessment project (Steele and others, 1976a; 1976b; 1979) is evaluating the environmental effects of energy development in the basin. The two main objectives of the assessment are: (1) To describe the hydrology of the basin prior to substantial coal-resource development (phase 1); and (2) to evaluate environmental and economic consequences of coal-resource development, particularly in terms of the water resources of the basin (phase 11 ). Details regarding the specific goals and objectives of the basin assessment are given in the above reports.

This report relates to the first of the above objectives by describing stream quality in the Yampa River basin through 1976, with particular emphasis on conditions from August 1975 through September 1976. The content of this report is, at times, relatively technical. This is intentional. The report is aimed not at planners and decisionmakers but rather at those persons assigned the task of having to design, implement, and interpret a riverbasin assessment. The techniques and procedures used to determine ambient stream quality in the Yampa River basin have been presented in detail so that their applicability to other river basins can be determined. For the planner and decisionmaker, the results presented in this report are summarized in less technical terms in phase-l (Steele and others, 1979) and phase-11 summary reports.

The authors wish to thank Phillip E. Stark and his staff, Routt County Department of Environmental Health, and Robert Russell and his staff, Routt National Forest, U.S. Forest Service, for assistance in planning the waterquality data-collection program and collecting data in Routt County.

\section{APPROACH}

Two techniques were used to assess ambient stream quality in the Yampa River basin. The first was to evaluate information accumulated as part of past and ongoing studies; the second was to design and implement a datacollection program to complement this prior knowledge. These aspects of the stream-quality assessment are discussed in detail below. 
Stream temperatures are measured intermittently by the U.S. Geological Survey at most stream-gaging sites at the same time discharge measurements are made, generally every 4 to 6 weeks. Such data were available for 34 sites throughout the Yampa River basin for 1960-75. Iorns, Hembree, Phoenix, and Oakland (1964) have published data on specific conductance and major inorganic constituents collected during 1944-58 in the Yampa River basin; a total of 102 samples was collected from 35 sites.

In addition to the above regional data, long-term, site-specific data on stream temperature, specific conductance, and major inorganic constituents are available for sites near the mouths of the Yampa and the Little Snake Rivers, as given below:

\begin{tabular}{|c|c|c|c|c|}
\hline \multirow{2}{*}{$\begin{array}{l}\text { Station } \\
\text { identi- } \\
\text { fication }\end{array}$} & \multirow[b]{2}{*}{ Station name ${ }^{1}$} & \multicolumn{3}{|c|}{ Data available } \\
\hline & & Stream temperature & $\begin{array}{l}\text { Specific } \\
\text { conductance }\end{array}$ & $\begin{array}{l}\text { Major inorganic } \\
\text { constituents }\end{array}$ \\
\hline 9251000 & $\begin{array}{c}\text { Yampa River near } \\
\text { Maybell, Colo. }\end{array}$ & $\begin{array}{l}\text { Daily, } 1951-73 \text { water } \\
\text { year; continuous, } \\
1976 \text { water year } \\
\text { to present. }\end{array}$ & $\begin{array}{l}\text { Daily, } 1951-73 \text { water } \\
\text { year; cont inuous, } \\
1976 \text { water year } \\
\text { to present. }\end{array}$ & $\begin{array}{l}1951 \text { water year } \\
\text { to present. }\end{array}$ \\
\hline 09259950 & $\begin{array}{l}\text { Little Snake River } \\
\text { above Lily, Colo. }\end{array}$ & $\begin{array}{l}\text { Daily, 1951-69 water } \\
\text { year. }\end{array}$ & $\begin{array}{l}\text { Daily, } 1951-69 \text { water } \\
\text { year. }\end{array}$ & $\begin{array}{l}1951-69 \text { water } \\
\text { year. }\end{array}$ \\
\hline 09260000 & $\begin{array}{l}\text { Little Snake River } \\
\text { near Lily, Colo. }\end{array}$ & $\begin{array}{l}\text { Continuous, } 1976^{\circ} \\
\text { water year to } \\
\text { present. }\end{array}$ & $\begin{array}{l}\text { Continuous, } 1976 \\
\text { water year to } \\
\text { present. }\end{array}$ & $\begin{array}{l}1970 \text { water year } \\
\text { to present. }\end{array}$ \\
\hline
\end{tabular}

ISee also figure 1 .

The daily and continuous stream-temperature and the daily specific-conductance data have been analyzed in this report; the continuous specific-conductance data have not been considered.

The two above sites on the Little Snake River are within $6 \mathrm{mi}(10 \mathrm{~km})$ of each other. These two sites have been considered equivalent for all data analyses of major inorganic constituents and specific conductance beginning on page 26; the two combined sites are referred to as the Little Snake River near Lily. Approximately 36 samples per year were collected through 1969 at the sites on the Little Snake and the Yampa Rivers; each sample was composited daily for the period of collection. Since 1969, individual monthly samples have been analyzed. 
Basinwide Reconnaissance--1975

After evaluating the historic data, a complementary basinwide reconnaissance was planned to collect samples at 85 sites during low-flow conditions. The locations of these sites are shown on figure 1 and are listed in table 1. All sites were visited during July 1975 to insure accessibility. The streams were sampled during the last week of August and the first week of September 1975. There was no streamflow at sites $Y-3, Y-5$, and $Y-38 A$ during this sampling period. Streamflow, water temperature, $\mathrm{pH}$, dissolved oxygen, and specific conductance were measured at the remaining 82 sites; samples for laboratory analyses of other physical, chemical, and biological characteristics also were collected. The data from the basinwide reconnaissance have been published by Giles and Brogden (1978).

\section{Quarterly Sampling Program--1975 to 1976}

Based on the results of the basinwide reconnaissance, additional samples were collected at 42 sites ( $\mathrm{fig} .1$ and table 1 ) to determine the response of stream quality to seasonal changes and to variations in stream discharge. Sampling was conducted during December 1975, and during March, June, and August-September 1976. Thirty-two of the sites were the same as those sampled during the basinwide reconnaissance; samples were collected at 10 new sites to determine sediment and nutrient concentrations in streams draining the Routt National Forest (table 1). The data from the quarterly sampling program have been published by the U.S. Geological Survey (1978).

\section{Related Studies}

At the present time (1979), samples are being collected monthly at 12 sites (table 1) which were included in the August-September 1975 reconnaissance but which were not continued in the quarterly sampling program. These samples are being collected as part of ongoing studies not directly associated with the Yampa River basin assessment (U.S. Geological Survey, 1976).

Water-quality data also have been collected at the following sites by the Colorado Department of Health for the periods indicated (see fig. 1): (1) Yampa River below Little Snake River (about $4 \mathrm{mi}$ or $6 \mathrm{~km}$ upstream from site Y-0) since 1968; (2) Little Snake River above Lily (about $6 \mathrm{mi}$ or $10 \mathrm{~km}$ upstream from site $Y-1$ ) since 1968; (3) Yampa River near Maybell (site $Y-17$ ) since 1968; (4) Yampa River at Milner (immediately upstream from Trout Creek) since 1968; and (5) Yampa River above Oak Creek confluence (about $1 \mathrm{mi}$ or $2 \mathrm{~km}$ downstream from site $\mathrm{Y}-71$ ) since 1970. Published analyses for Sage Creek, Grassy Creek, and the Yampa River in the vicinity of the water intake for the Hayden Powerplant for the period 1971-76 also are available (StearnsRoger, Inc., 1973-76). Because of variations in techniques used in the collection and analyses of water samples, only stream-temperature data from the above sources have been used in this study. However, results of aquaticbiological studies by Eddy (1975), Ames (1977), and Canton and Ward (1977) have been considered in the analyses of data presented in this report. 
Table 1.--Description of sampling

[R, reconnaissance site, August-September 1975; Q, quarterly sampling site, December 1975 directly associated with the Yampa River basin assessment. Ten sites marked only by $Q$ draining the Routt National Forest (p. 5)].

\begin{tabular}{|c|c|}
\hline $\begin{array}{l}\text { tation number } \\
\text { on figure } 1\end{array}$ & Station name \\
\hline $\begin{array}{l}Y-0 \\
Y-1 \\
Y-2 \\
Y-3 \\
Y-4\end{array}$ & $\begin{array}{l}\text { Yampa River at Deerlodge Park } \\
\text { Little Snake River near Li Lly } \\
\text { Little Snake River near Baggs } \\
\text { Sand Creek near Baggs } \\
\text { Little Snake River above Thornburgh Gulch, near Baggs }\end{array}$ \\
\hline $\begin{array}{l}Y-5 \\
Y-6 \\
y-7 \\
Y-8 \\
Y-9\end{array}$ & $\begin{array}{l}\text { Muddy Creek above Baggs } \\
\text { Muddy Creek below Sulphur } \\
\text { Wil low Creek near Dixon } \\
\text { Little Snake River near Dixon } \\
\text { Savery Creek at Savery }\end{array}$ \\
\hline $\begin{array}{l}Y-10 \\
Y-10 A \\
Y-11 \\
Y-11 A \\
Y-12\end{array}$ & $\begin{array}{l}\text { Savery Creek near Savery } \\
\text { Savery Creek at upper station, near Savery } \\
\text { Slater Fork near Slater } \\
\text { Battle Creek near Slater } \\
\text { Little Snake River near Slater }\end{array}$ \\
\hline $\begin{array}{l}Y-13 \\
Y-14 \\
\gamma-15 \\
Y-17 \\
Y-20\end{array}$ & $\begin{array}{l}\text { Independence Creek near Columbine } \\
\text { King Solomon Creek tributary near Columbine } \\
\text { Whiskey Creek above Whiskey Park, near Columbine } \\
\text { Yampa River near Maybell } \\
\text { Yampa River at Government Bridge }\end{array}$ \\
\hline $\begin{array}{l}Y-21 \\
Y-22 \\
Y-23 \\
Y-24 \\
Y-25\end{array}$ & $\begin{array}{l}\text { Milk Creek near mouth, near Axial } \\
\text { Jubb Creek near Axial } \\
\text { Wilson Creek near Axial } \\
\text { Taylor Creek at mouth, near Axial } \\
\text { Stinking Gulch at Iles Grove- }\end{array}$ \\
\hline $\begin{array}{l}Y-26 \\
Y-27 \\
Y-28 \\
Y-29 \\
Y-29 A\end{array}$ & $\begin{array}{l}\text { Stinking Gulch near Thornburgh } \\
\text { Good Spring Creek at Axial } \\
\text { Milk Creek near Thornburghe } \\
\text { Yampa River above Bell Rock Gulch, near Hamilton } \\
\text { Will iams Fork at mouth, near Hamilton }\end{array}$ \\
\hline $\begin{array}{l}Y-30 \\
Y-31 \\
Y-32 \\
Y-33 \\
Y-34\end{array}$ & $\begin{array}{l}\text { Williams Fork below Morapos Creek, at Hamilton } \\
\text { Williams Fork below Jeffway Gulch, near Hamilton } \\
\text { South Fork of Will iams Fork at mouth, near Pagoda } \\
\text { Cedar Creek at mouth, near Pagoda } \\
\text { Coal Creek at mouth, near Pagoda }\end{array}$ \\
\hline $\begin{array}{l}Y-35 \\
Y-36 \\
Y-37 \\
Y-38 \\
Y-38 A\end{array}$ & $\begin{array}{l}\text { South Fork of Williams Fork, near Pagoda } \\
\text { Hayden Gulch near Pagoda } \\
\text { East Fork of Will liams Fork, near Pagoda } \\
\text { Yampa River above Will iams Fork, near Hamilton } \\
\text { Johnson Gulch near Craig }\end{array}$ \\
\hline $\begin{array}{l}Y-38 B \\
Y-39 \\
Y-40 \\
Y-40 A \\
Y-41 A\end{array}$ & $\begin{array}{l}\text { Yampa River below Craig } \\
\text { Yampa River at Craig } \\
\text { Fortification Creek below Craiger } \\
\text { Fortification Creek above Craig } \\
\text { Yampa River below Elkhead Creek, near Craig }\end{array}$ \\
\hline
\end{tabular}


sites in the Yampa River basin

through August-September 1976; 0, ongoing (1979) U.S. Geological Survey sampling site not are sites added primarily to determine sediment and nutrient concentrations in streams

\begin{tabular}{|c|c|c|c|c|c|}
\hline State & County & $\begin{array}{l}\text { Town- } \\
\text { ship }\end{array}$ & Range & $\begin{array}{c}\text { Station } \\
\text { identification } \\
\end{array}$ & $\begin{array}{l}\text { Site } \\
\text { Code } \\
\end{array}$ \\
\hline $\begin{array}{l}\text { Colo. } \\
\text { Colo. } \\
\text { Wyo. } \\
\text { Wyo. } \\
\text { Colo. }\end{array}$ & $\begin{array}{l}\text { Moffat } \\
\text { Moffat } \\
\text { Sweetwater } \\
\text { Carbon } \\
\text { Moffat }\end{array}$ & $\begin{array}{r}6 N \\
7 N \\
12 N \\
12 N \\
12 N\end{array}$ & $\begin{array}{l}99 W \\
98 W \\
94 W \\
93 W \\
93 W\end{array}$ & $\begin{array}{r}09260050 \\
09260000 \\
09259700 \\
410224107515600 \\
405937107462500\end{array}$ & $\begin{array}{l}R \\
R, 0 \\
R \\
R \\
R\end{array}$ \\
\hline $\begin{array}{l}\text { Wyo. } \\
\text { Wyo. } \\
\text { Colo. } \\
\text { Wyo. } \\
\text { Wyo. }\end{array}$ & $\begin{array}{l}\text { Carbon } \\
\text { Carbon } \\
\text { Moffat } \\
\text { Carbon } \\
\text { Carbon }\end{array}$ & $\begin{array}{l}13 N \\
17 N \\
11 N \\
12 N \\
12 N\end{array}$ & $\begin{array}{l}91 W \\
92 W \\
90 W \\
90 W \\
89 W\end{array}$ & $\begin{array}{r}09258900 \\
412613107452100 \\
09258000 \\
09257000 \\
09256500\end{array}$ & $\begin{array}{l}R \\
R \\
R \\
R, Q \\
R\end{array}$ \\
\hline $\begin{array}{l}\text { Wyo. } \\
\text { Wyo. } \\
\text { Colo. } \\
\text { Wyo. } \\
\text { Colo. }\end{array}$ & $\begin{array}{l}\text { Carbon } \\
\text { Carbon } \\
\text { Moffat } \\
\text { Carbon } \\
\text { Routt }\end{array}$ & $\begin{array}{l}13 \mathrm{~N} \\
14 \mathrm{~N} \\
12 \mathrm{~N} \\
12 \mathrm{~N} \\
12 \mathrm{~N}\end{array}$ & $\begin{array}{l}89 W \\
89 W \\
89 W \\
88 W \\
87 W\end{array}$ & $\begin{array}{l}09256000 \\
09255500 \\
09255000 \\
09253500 \\
09253000\end{array}$ & $\begin{array}{l}R \\
R \\
R \\
R \\
R\end{array}$ \\
\hline $\begin{array}{l}\text { Colo. } \\
\text { Colo. } \\
\text { Colo. } \\
\text { Colo. } \\
\text { Colo. }\end{array}$ & $\begin{array}{l}\text { Routt } \\
\text { Routt } \\
\text { Rout t } \\
\text { Moffat } \\
\text { Moffat }\end{array}$ & $\begin{array}{r}11 N \\
11 N \\
12 N \\
6 N \\
6 N\end{array}$ & $\begin{array}{l}85 W \\
85 W \\
85 W \\
95 W \\
94 W\end{array}$ & $\begin{array}{r}405200106575800 \\
405340106543400 \\
405855106543500 \\
09251000 \\
402650107541900\end{array}$ & $\begin{array}{l}R \\
R \\
R \\
R, 0 \\
R\end{array}$ \\
\hline $\begin{array}{l}\text { Colo. } \\
\text { Colo. } \\
\text { Colo. } \\
\text { Colo. } \\
\text { Colo. }\end{array}$ & $\begin{array}{l}\text { Moffat } \\
\text { Moffat } \\
\text { Moffat } \\
\text { Moffat } \\
\text { Moffat }\end{array}$ & $\begin{array}{l}5 N \\
4 N \\
4 N \\
4 N \\
5 N\end{array}$ & $\begin{array}{l}92 W \\
93 W \\
93 W \\
93 W \\
92 W\end{array}$ & $\begin{array}{r}402154107453100 \\
09250610 \\
09250600 \\
09250510 \\
402005107411900\end{array}$ & $\begin{array}{l}R, Q \\
R, 0 \\
R, 0 \\
R, 0 \\
R\end{array}$ \\
\hline $\begin{array}{l}\text { Colo. } \\
\text { Colo. } \\
\text { Colo. } \\
\text { Colo. } \\
\text { Colo. }\end{array}$ & $\begin{array}{l}\text { Moffat } \\
\text { Moffat } \\
\text { Rio Blanco } \\
\text { Moffat } \\
\text { Moffat }\end{array}$ & $\begin{array}{l}3 N \\
4 N \\
3 N \\
5 N \\
6 N\end{array}$ & $\begin{array}{l}92 W \\
93 W \\
92 W \\
92 W \\
91 W\end{array}$ & $\begin{array}{r}401601107395300 \\
09250400 \\
09250000 \\
402456107413500 \\
09249750\end{array}$ & $\begin{array}{l}R, Q \\
R \\
R, Q \\
R \\
R, O\end{array}$ \\
\hline $\begin{array}{l}\text { Colo. } \\
\text { Colo. } \\
\text { Colo. } \\
\text { Colo. } \\
\text { Colo. }\end{array}$ & $\begin{array}{l}\text { Moffat } \\
\text { Moffat } \\
\text { Routt } \\
\text { Routt } \\
\text { Routt }\end{array}$ & $\begin{array}{l}5 N \\
5 N \\
4 N \\
3 N \\
3 N\end{array}$ & $\begin{array}{l}91 W \\
90 W \\
89 W \\
89 W \\
89 W\end{array}$ & $\begin{array}{l}402221107365200 \\
402152107301300 \\
401857107243500 \\
401546107260700 \\
401530107262300\end{array}$ & $\begin{array}{l}R \\
R, Q \\
R, Q \\
R \\
R\end{array}$ \\
\hline $\begin{array}{l}\text { Colo. } \\
\text { Colo. } \\
\text { Colo. } \\
\text { Colo. } \\
\text { Colo. }\end{array}$ & $\begin{array}{l}\text { Rio Blanco } \\
\text { Routt } \\
\text { Routt } \\
\text { Moffat } \\
\text { Moffat }\end{array}$ & $\begin{array}{l}3 N \\
4 N \\
4 N \\
6 N \\
6 N\end{array}$ & $\begin{array}{l}90 \mathrm{~W} \\
89 \mathrm{~W} \\
88 \mathrm{~W} \\
91 \mathrm{~W} \\
91 \mathrm{~W}\end{array}$ & $\begin{array}{r}09249200 \\
401913107204100 \\
09249000 \\
402627107390700 \\
402845107364300\end{array}$ & $\begin{array}{l}R \\
R \\
R, Q \\
R \\
R\end{array}$ \\
\hline $\begin{array}{l}\text { Colo. } \\
\text { Colo. } \\
\text { Colo. } \\
\text { Colo. } \\
\text { Colo. }\end{array}$ & $\begin{array}{l}\text { Moffat } \\
\text { Moffat } \\
\text { Moffat } \\
\text { Moffat } \\
\text { Moffat }\end{array}$ & $\begin{array}{l}6 N \\
6 N \\
6 N \\
7 N \\
6 N\end{array}$ & $\begin{array}{l}91 W \\
91 W \\
90 W \\
90 W \\
90 W\end{array}$ & $\begin{array}{r}09247600 \\
09247500 \\
403038107321800 \\
403251107314200 \\
09246550\end{array}$ & $\begin{array}{l}R, 0 \\
R, Q \\
R \\
R, Q \\
R, 0\end{array}$ \\
\hline
\end{tabular}


Table 1.--Description of sampling sites

\begin{tabular}{|c|c|}
\hline $\begin{array}{l}\text { Station number } \\
\text { on figure } 1 \\
\end{array}$ & Station name \\
\hline $\begin{array}{l}Y-42 \\
Y-42 A \\
Y-42 B \\
Y-43 \\
Y-44\end{array}$ & $\begin{array}{l}\text { Elkhead Creek near Craig } \\
\text { Elkhead Creek above Elkhead Reservoir } \\
\text { North Fork Elkhead Creek near Elkhead } \\
\text { Elkhead Creek near Elkhead } \\
\text { Yampa River below Hayden }\end{array}$ \\
\hline $\begin{array}{l}Y-45 \\
Y-46 \\
Y-46 A \\
Y-47 \\
Y-48\end{array}$ & $\begin{array}{l}\text { Yampa River at Hayden } \\
\text { Sage Creek near Hayden } \\
\text { Sage Creek near Mount Harris } \\
\text { Yampa River below diversion, near Hayden } \\
\text { Grassy Creek near Mount Harris }\end{array}$ \\
\hline $\begin{array}{l}Y-49 \\
Y-49 A \\
Y-50 \\
Y-51 \\
Y-52\end{array}$ & $\begin{array}{l}\text { Grassy Creek at Grassy Gap } \\
\text { Wolf Creek near Hayden } \\
\text { Yampa River below Trout Creek, at Milner } \\
\text { Fish Creek at mouth, near Milner } \\
\text { Fish Creek near Milner }\end{array}$ \\
\hline $\begin{array}{l}Y-52 A \\
Y-53 \\
Y-54 \\
Y-55 \\
Y-56\end{array}$ & $\begin{array}{l}\text { Trout Creek below Foidel Creek, near Milner } \\
\text { Foidel Creek at mouth, near Oak Creek } \\
\text { Foidel Creek near Oak Creek } \\
\text { Middle Creek near Oak Creek } \\
\text { Trout Creek above Foidel Creek, near Milner }\end{array}$ \\
\hline $\begin{array}{l}Y-57 \\
Y-58 \\
Y-58 A \\
Y-59 \\
Y-60\end{array}$ & $\begin{array}{l}\text { Trout Creek near Phippsburg } \\
\text { Elk River near Trull } \\
\text { Mad Creek near Steamboat Springs } \\
\text { Elk River at Clark } \\
\text { Beaver Creek near Hahns Peak }\end{array}$ \\
\hline $\begin{array}{l}Y-61 \\
Y-62 \\
Y-62 A \\
Y-62 B \\
Y-63\end{array}$ & $\begin{array}{l}\text { Ways Gulch at Hahns Peak } \\
\text { Deep Creek at Hahns Peak } \\
\text { Elk River below South Fork, at Hinman Park } \\
\text { North Fork Elk River near Hinman Park } \\
\text { Yampa River above Elk River, near Milner }\end{array}$ \\
\hline $\begin{array}{l}Y-63 A \\
Y-64 \\
Y-64 A \\
Y-64 B \\
Y-64 C\end{array}$ & $\begin{array}{l}\text { Yampa River above sewage-treatment plant, below Steamboat Springs } \\
\text { Yampa River at Steamboat Springs } \\
\text { Fish Creek near Steamboat Springs } \\
\text { Burgess Creek below ski area, near Steamboat Springs } \\
\text { Burgess Creek above ski area, near Steamboat Springs }\end{array}$ \\
\hline $\begin{array}{l}Y-65 \\
Y-65 A \\
Y-66 \\
Y-67 \\
Y-68\end{array}$ & $\begin{array}{l}\text { North Fork Walton Creek near Rabbit Ears Pass } \\
\text { Yampa River below Oak Creek, near Steamboat Springs } \\
\text { Oak Creek near Steamboat Springs } \\
\text { Oak Creek above Routt } \\
\text { Oak Creek drain near Oak Creek }\end{array}$ \\
\hline $\begin{array}{l}Y-69 \\
Y-70 \\
Y-71 \\
Y-71 A \\
Y-71 B\end{array}$ & $\begin{array}{l}\text { Oak Creek above Oak Creek drain, near Oak Creek } \\
\text { Oak Creek near Oak Creek } \\
\text { Yampa River above Oak Creek, near Steamboat Springs } \\
\text { Harrison Creek at mouth, near Blacktail Mountain } \\
\text { Little liorrison Creek near Stagecoach }\end{array}$ \\
\hline $\begin{array}{l}Y-72 \\
Y-73 \\
Y-74 \\
Y-75 \\
Y-76\end{array}$ & $\begin{array}{l}\text { Yampa River at Phippsburg } \\
\text { Yampa River below Yampa } \\
\text { Philli ips Creek near Yampa } \\
\text { Chimney Creek at Trapper } \\
\text { Bear River near Toponas }\end{array}$ \\
\hline
\end{tabular}


in the Yampa River basin--Continued

\begin{tabular}{|c|c|c|c|c|c|}
\hline State & County & $\begin{array}{l}\text { Town- } \\
\text { ship }\end{array}$ & Range & $\begin{array}{c}\text { Station } \\
\text { identification } \\
\end{array}$ & $\begin{array}{l}\text { Site } \\
\text { Code } \\
\end{array}$ \\
\hline $\begin{array}{l}\text { Colo. } \\
\text { Colo. } \\
\text { Colo. } \\
\text { Colo. } \\
\text { Colo. }\end{array}$ & $\begin{array}{l}\text { Moffat } \\
\text { Routt } \\
\text { Routt } \\
\text { Routt } \\
\text { Routt }\end{array}$ & $\begin{array}{l}7 N \\
7 N \\
8 N \\
8 N \\
6 N\end{array}$ & $\begin{array}{l}90 \mathrm{~W} \\
89 \mathrm{~W} \\
88 \mathrm{~W} \\
88 \mathrm{~W} \\
88 \mathrm{~W}\end{array}$ & $\begin{array}{r}09246500 \\
403530107191300 \\
09245500 \\
09245000 \\
402930107174200\end{array}$ & $\begin{array}{l}R, Q \\
R, Q \\
Q \\
R \\
R, Q\end{array}$ \\
\hline $\begin{array}{l}\text { Colo. } \\
\text { Colo. } \\
\text { Colo. } \\
\text { Colo. } \\
\text { Colo. }\end{array}$ & $\begin{array}{l}\text { Routt } \\
\text { Routt } \\
\text { Routt } \\
\text { Routt } \\
\text { Routt }\end{array}$ & $\begin{array}{l}6 N \\
6 N \\
5 N \\
6 N \\
6 N\end{array}$ & $\begin{array}{l}88 W \\
37 W \\
88 W \\
87 W \\
87 W\end{array}$ & $\begin{array}{r}403006107154800 \\
402918107094400 \\
402522107134100 \\
09244410 \\
09244300\end{array}$ & $\begin{array}{l}R, Q \\
R, Q \\
R, Q \\
R, Q \\
R, Q\end{array}$ \\
\hline $\begin{array}{l}\text { Colo. } \\
\text { Colo. } \\
\text { Colo. } \\
\text { Colo. } \\
\text { Colo. }\end{array}$ & $\begin{array}{l}\text { Routt } \\
\text { Routt } \\
\text { Routt } \\
\text { Routt } \\
\text { Routt }\end{array}$ & $\begin{array}{l}5 N \\
6 N \\
6 N \\
5 N \\
4 N\end{array}$ & $\begin{array}{l}87 W \\
87 W \\
86 W \\
86 W \\
87 W\end{array}$ & $\begin{array}{r}402330107082000 \\
402832107080200 \\
402854107020500 \\
402530106585700 \\
09244100\end{array}$ & $\begin{array}{l}R, Q \\
R \\
R, Q \\
R, Q \\
R, Q\end{array}$ \\
\hline $\begin{array}{l}\text { Colo. } \\
\text { Colo. } \\
\text { Colo. } \\
\text { Colo. } \\
\text { Colo. }\end{array}$ & $\begin{array}{l}\text { Routt } \\
\text { Routt } \\
\text { Routt } \\
\text { Routt } \\
\text { Routt }\end{array}$ & $\begin{array}{l}6 N \\
5 N \\
5 N \\
5 N \\
5 N\end{array}$ & $\begin{array}{l}85 W \\
86 W \\
86 W \\
86 W \\
85 W\end{array}$ & $\begin{array}{r}402536106582700 \\
09243900 \\
09243800 \\
09243700 \\
402416106580800\end{array}$ & $\begin{array}{l}R \\
R, 0 \\
R, 0 \\
R, 0 \\
R\end{array}$ \\
\hline $\begin{array}{l}\text { Colo. } \\
\text { Colo. } \\
\text { Colo. } \\
\text { Colo. } \\
\text { Colo. }\end{array}$ & $\begin{array}{l}\text { Rio Blanco } \\
\text { Routt } \\
\text { Routt } \\
\text { Routt } \\
\text { Routt }\end{array}$ & $\begin{array}{l}2 N \\
6 N \\
7 N \\
9 N \\
9 N\end{array}$ & $\begin{array}{l}87 W \\
85 W \\
85 W \\
85 W \\
85 W\end{array}$ & $\begin{array}{r}09243000 \\
09242500 \\
09242000 \\
09241000 \\
404610106545600\end{array}$ & $\begin{array}{l}R \\
R, Q \\
Q \\
R \\
R\end{array}$ \\
\hline $\begin{array}{l}\text { Colo. } \\
\text { Colo. } \\
\text { Colo. } \\
\text { Colo. } \\
\text { Colo. }\end{array}$ & $\begin{array}{l}\text { Routt } \\
\text { Routt } \\
\text { Routt } \\
\text { Routt } \\
\text { Routt }\end{array}$ & $\begin{array}{r}10 N \\
10 N \\
9 N \\
9 N \\
6 N\end{array}$ & $\begin{array}{l}85 W \\
85 W \\
84 W \\
84 W \\
85 W\end{array}$ & $\begin{array}{l}404756106555100 \\
404845106571400 \\
404506106492800 \\
404620106462200 \\
l_{1} 02932106564900\end{array}$ & $\begin{array}{l}R \\
R \\
R, Q \\
Q \\
R, Q\end{array}$ \\
\hline $\begin{array}{l}\text { Colo. } \\
\text { Colo. } \\
\text { Colo. } \\
\text { Colo. } \\
\text { Colo. }\end{array}$ & $\begin{array}{l}\text { Routt } \\
\text { Routt } \\
\text { Routt } \\
\text { Routt } \\
\text { Routt }\end{array}$ & $\begin{array}{l}6 N \\
6 N \\
6 N \\
6 N \\
6 N\end{array}$ & $\begin{array}{l}84 W \\
34 W \\
84 W \\
34 W \\
84 W\end{array}$ & $\begin{array}{r}402934106505400 \\
09239500 \\
09239000 \\
402720106481500 \\
402802106471000\end{array}$ & $\begin{array}{l}Q \\
R, Q \\
Q \\
Q \\
Q\end{array}$ \\
\hline $\begin{array}{l}\text { Colo. } \\
\text { Colo. } \\
\text { Colo. } \\
\text { Colo. } \\
\text { Colo. }\end{array}$ & $\begin{array}{l}\text { Grand } \\
\text { Routt } \\
\text { Routt } \\
\text { Routt } \\
\text { Routt }\end{array}$ & $\begin{array}{l}5 N \\
6 N \\
5 N \\
4 N \\
4 N\end{array}$ & $\begin{array}{l}82 W \\
84 W \\
84 W \\
85 W \\
85 W\end{array}$ & $\begin{array}{r}09238300 \\
402544106493600 \\
402356106503000 \\
401741106574600 \\
401729106575400\end{array}$ & $\begin{array}{l}R, Q \\
Q \\
R \\
R, Q \\
R, Q\end{array}$ \\
\hline $\begin{array}{l}\text { Colo. } \\
\text { Colo. } \\
\text { Colo. } \\
\text { Colo. } \\
\text { Colo. }\end{array}$ & $\begin{array}{l}\text { Routt } \\
\text { Routt } \\
\text { Routt } \\
\text { Routt } \\
\text { Routt }\end{array}$ & $\begin{array}{l}4 N \\
3 N \\
5 N \\
5 N \\
4 N\end{array}$ & $\begin{array}{l}85 W \\
86 W \\
84 W \\
84 W \\
84 W\end{array}$ & $\begin{array}{r}401725106575600 \\
09238000 \\
402356106500000 \\
402056106571600 \\
401634106502200\end{array}$ & $\begin{array}{l}R, Q \\
R, Q \\
R, Q \\
Q \\
Q\end{array}$ \\
\hline $\begin{array}{l}\text { Colo } \\
\text { Colo. } \\
\text { Colo. } \\
\text { Colo. } \\
\text { Colo. }\end{array}$ & $\begin{array}{l}\text { Routt } \\
\text { Routt } \\
\text { Routt } \\
\text { Routt } \\
\text { Garfield }\end{array}$ & $\begin{array}{l}3 N \\
3 N \\
2 N \\
2 N \\
1 N\end{array}$ & $\begin{array}{l}85 \mathrm{~W} \\
85 \mathrm{~W} \\
85 \mathrm{~W} \\
85 \mathrm{~W} \\
86 \mathrm{~W}\end{array}$ & $\begin{array}{r}401418106562200 \\
401048106544800 \\
400759106532500 \\
400612106524800 \\
09236000\end{array}$ & $\begin{array}{l}R, Q \\
R \\
R \\
R, Q \\
R\end{array}$ \\
\hline
\end{tabular}




\section{RESULTS AND DISCUSSION}

The results of various statistical analyses of the stream-quality data for the Yampa River basin are discussed in the following sections. The data also are evaluated in terms of current Colorado water-quality standards. One measure of stream quality not included in the following discussion is transport of suspended and total sediment in streams of the basin. That aspect of the stream quality has been studied by Andrews (1977; 1978).

\section{$\underline{\text { Stream Temperature }}$}

Typical seasonal stream-temperature patterns for the Yampa River near Maybell, Colo. (site Y-17), and the Little Snake River above Lily, Colo., are shown on figure 2. Similar seasonal variations persist from year to year. Because the seasonal pattern is cyclic and approximates a sine function, the annual increments of the periods of record at these two sites were analyzed using a harmonic-analysis procedure as proposed by Ward (1963) and Collings (1969). This procedure uses a least-squares regression to fit a sine function of the form

$$
T(t)=M+A \cdot[\sin (b t+C)]
$$

where $T(t)=$ stream temperature, in degrees Celsius, on day $t$;

$M=$ harmonic-mean temperature, in degrees Celsius;

$A=$ ampl itude, in degrees Celsius;

$b=0.0172$ radians per day $=2 \pi \div 365$ days; and

$C=$ phase angle, in radians.

The procedure has been documented in a computer program by Steele (1974).

The results of the harmonic analyses as applied to the daily streamtemperature data for the Yampa River near Maybell (site $Y-17$ ), the Little Snake River above Lily, and the Little Snake River near Lily (site Y-1) are given in table 2. Instantaneous daily stream temperatures generally are measured randomly during daylight hours. During the warmer months, stream temperatures undergo a diel fluctuation (fig. 3) such that temperatures measured during daylight hours are biased toward the maximum values. Thus, harmonic coefficients determined from instantaneous daily stream temperatures might be expected to be somewhere between those determined from daily mean temperatures and those determined from daily maximum temperatures. A procedure for time-trend analysis used by Steele, Gilroy, and Hawkinson (1974) was applied to the stream-temperature characteristics in table 2. Using a significance level of 0.01 , no changes in harmonic-mean temperature, amplitude, or phase angle were revealed at either of the two sites for the period of record. 


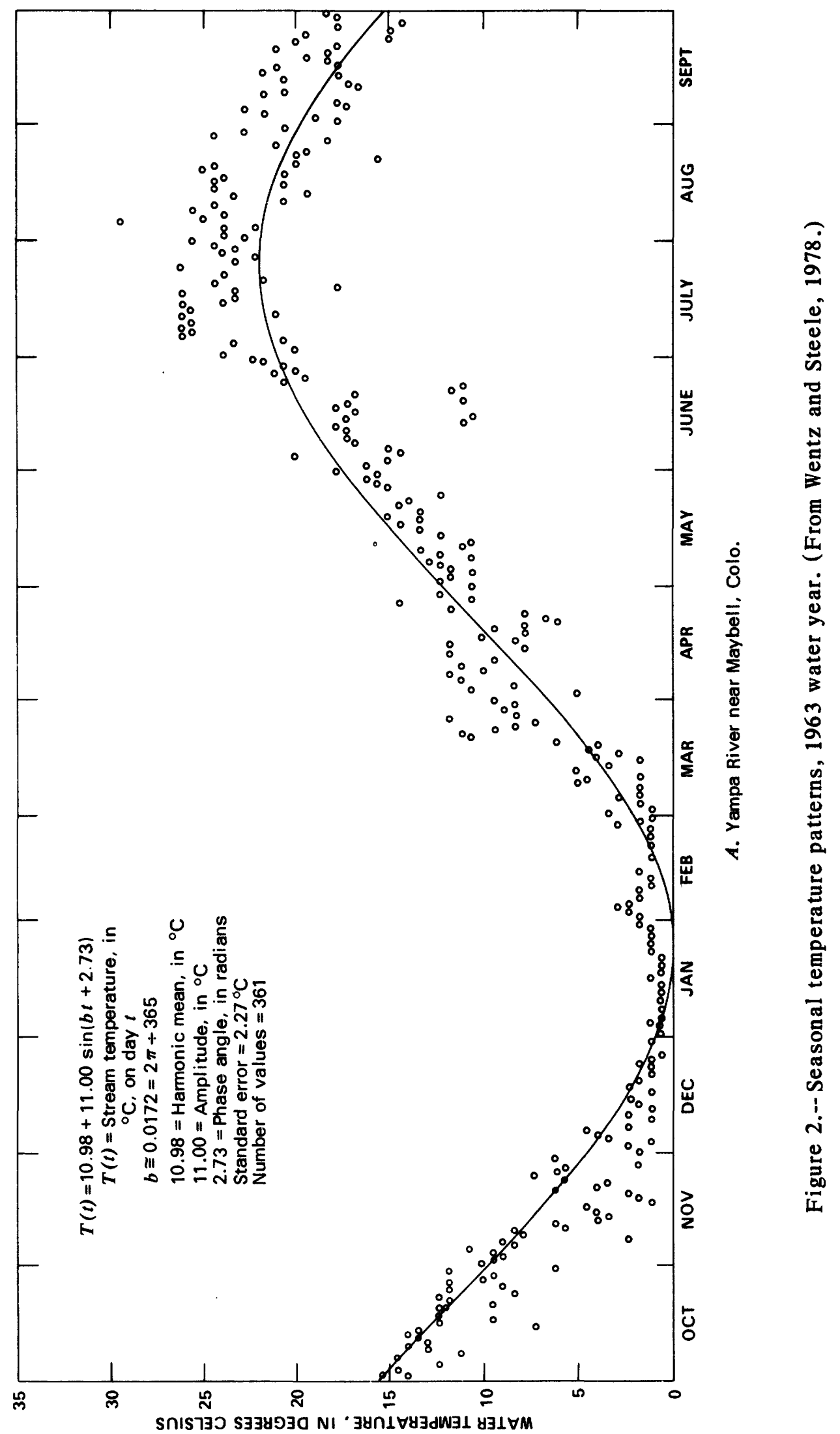




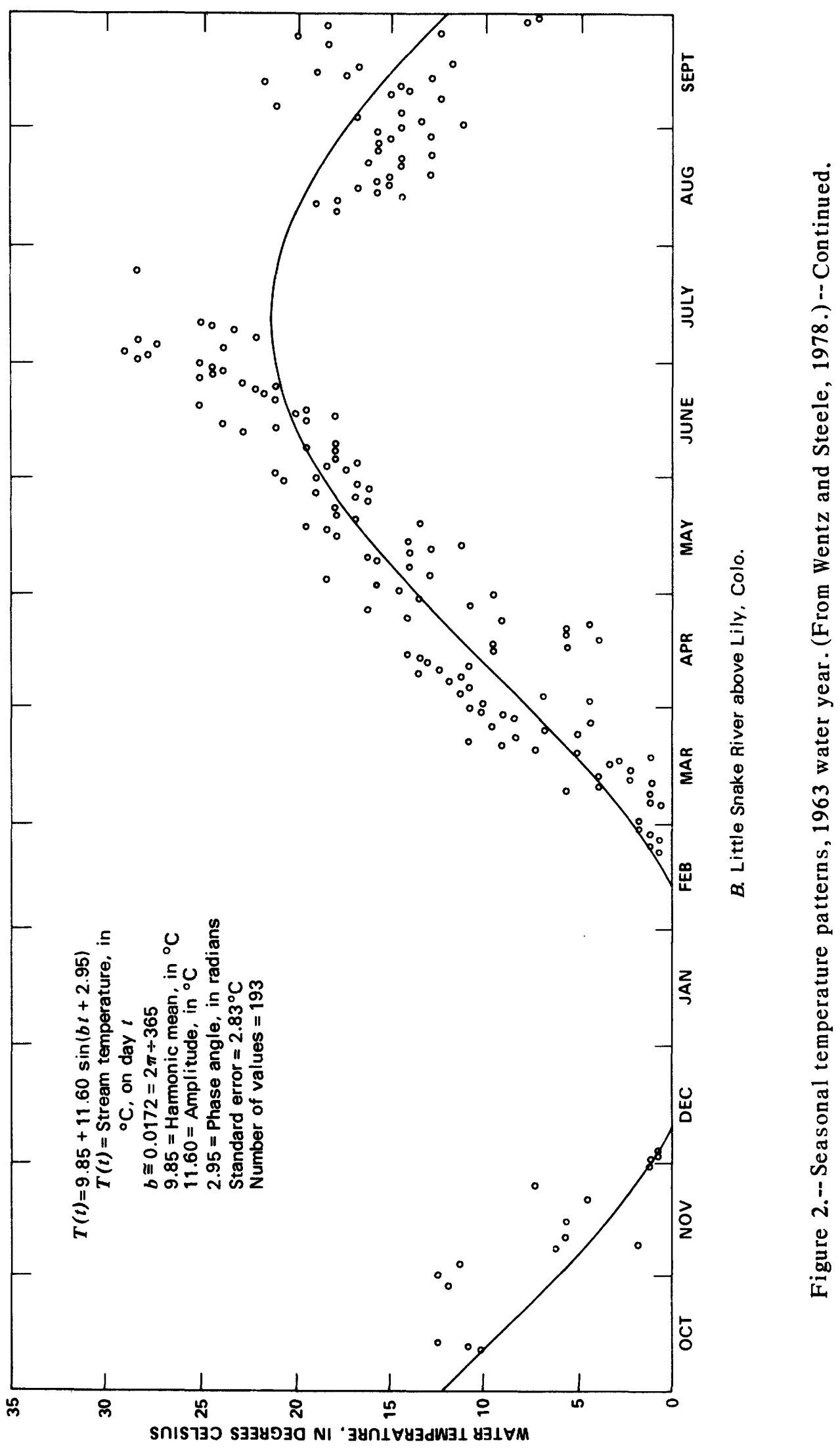


Table 2.--Harmonic analysis of daily stream temperatures in the Yampa River basin

\begin{tabular}{|c|c|c|c|c|c|c|}
\hline $\begin{array}{l}\text { Water } \\
\text { year }\end{array}$ & $\begin{array}{c}\text { Number } \\
\text { of } \\
\text { meas- } \\
\text { urements }\end{array}$ & $\begin{array}{l}\text { Mean } \\
\left({ }^{\circ} \mathrm{C}\right)\end{array}$ & $\begin{array}{l}\text { Amp l i tude } \\
\left({ }^{\circ} \mathrm{C}\right)\end{array}$ & $\begin{array}{c}\text { Phase } \\
\text { angle } \\
\text { (radians) }\end{array}$ & $\begin{array}{l}\text { Standard } \\
\text { error of } \\
\text { estimate } \\
\text { of mean } \\
\left({ }^{\circ} \mathrm{C}\right)\end{array}$ & $\begin{array}{c}\text { Percentage } \\
\text { of } \\
\text { variation } \\
\text { explained }\end{array}$ \\
\hline
\end{tabular}

09251000 Yampa River near Maybell, Colo. ${ }^{1}$ (site Y-17)

\begin{tabular}{lrrrrrl}
\hline 1951 & 293 & 10.5 & 10.5 & 2.6 & 2.2 & 93 \\
1952 & 340 & 9.7 & 11.6 & 2.7 & 2.0 & 95 \\
1953 & 354 & 10.8 & 12.1 & 2.6 & 2.6 & 92 \\
1954 & 313 & 10.6 & 12.9 & 2.7 & 2.0 & 95 \\
1955 & 361 & 9.9 & 12.3 & 2.6 & 2.2 & 94 \\
1956 & 354 & 10.0 & 11.8 & 2.7 & 2.1 & 94 \\
1957 & 280 & 9.0 & 10.6 & 2.7 & 3.0 & 83 \\
1958 & 287 & 10.3 & 11.9 & 2.7 & 2.5 & 90 \\
1959 & 282 & 10.5 & 9.9 & 2.7 & 2.5 & 87 \\
1960 & 281 & 9.7 & 11.2 & 2.7 & 2.9 & 87 \\
& & & & & & \\
1961 & 238 & 10.5 & 11.3 & 2.7 & 2.7 & 88 \\
1962 & 293 & 9.4 & 11.1 & 2.7 & 2.3 & 91 \\
1963 & 361 & 11.0 & 11.0 & 2.7 & 2.4 & 91 \\
1964 & 357 & 8.9 & 9.8 & 2.4 & 2.5 & 89 \\
1965 & 281 & 8.6 & 9.4 & 2.5 & 2.6 & 85 \\
1966 & 301 & 9.1 & 8.3 & 2.5 & 3.5 & 70 \\
1967 & 338 & 10.0 & 10.0 & 2.6 & 3.0 & 84 \\
1968 & 363 & 8.4 & 8.9 & 2.6 & 2.8 & 83 \\
1969 & 349 & 10.4 & 12.0 & 2.7 & 2.9 & 90 \\
1970 & 364 & 10.1 & 10.9 & 2.5 & 2.8 & 89 \\
& & & & & & \\
1971 & 363 & 10.6 & 11.6 & 2.4 & 2.6 & 91 \\
1972 & 358 & 10.0 & 10.8 & 2.8 & 3.4 & 84 \\
1973 & 304 & 9.4 & 9.8 & 2.7 & 2.4 & 88 \\
1976 & 114 & 8.6 & 13.4 & 2.8 & 1.6 & 95 \\
1977 & 177 & 9.6 & 15.2 & 2.8 & 2.2 & 91
\end{tabular}


Table 2.--Harmonic analysis of daily stream temperatures in the Yampa River basin--Continued

\begin{tabular}{|c|c|c|c|c|c|c|}
\hline $\begin{array}{l}\text { Water } \\
\text { year }\end{array}$ & $\begin{array}{c}\text { Number } \\
\text { of } \\
\text { meas- } \\
\text { urements }\end{array}$ & $\begin{array}{l}\text { Mean } \\
\left({ }^{\circ} \mathrm{C}\right)\end{array}$ & $\begin{array}{l}\text { Ampl itude } \\
\left({ }^{\circ} \mathrm{C}\right)\end{array}$ & $\begin{array}{c}\text { Phase } \\
\text { angle } \\
\text { (radians) }\end{array}$ & $\begin{array}{l}\text { Standard } \\
\text { error of } \\
\text { estimate } \\
\text { of mean } \\
\left({ }^{\circ} \mathrm{C}\right)\end{array}$ & $\begin{array}{c}\text { Percentage } \\
\text { of } \\
\text { variation } \\
\text { explained }\end{array}$ \\
\hline
\end{tabular}

09259950 Little Snake River above Lily, Colo. ${ }^{2}$

\begin{tabular}{rrrrrrl}
\hline 1951 & 180 & 9.3 & 9.3 & 2.8 & 2.0 & 92 \\
1952 & 128 & 6.5 & 9.5 & 2.9 & 1.9 & 83 \\
1953 & 241 & 6.4 & 10.1 & 3.0 & 2.3 & 84 \\
1954 & 238 & 7.1 & 9.3 & 3.0 & 2.1 & 86 \\
1955 & 234 & 6.6 & 12.8 & 2.8 & 3.2 & 80 \\
1956 & 235 & 7.3 & 15.0 & 2.8 & 3.1 & 86 \\
1957 & 255 & 10.4 & 11.1 & 2.7 & 3.4 & 82 \\
1958 & 269 & 10.3 & 11.6 & 2.8 & 3.4 & 80 \\
1959 & 279 & 10.6 & 12.2 & 2.8 & 3.2 & 86 \\
1960 & 207 & 10.5 & 13.5 & 2.8 & 3.1 & 86 \\
& & & & & & \\
1961 & 239 & 10.7 & 11.4 & 2.7 & 4.2 & 75 \\
1962 & 175 & 9.0 & 10.2 & 2.8 & 2.8 & 79 \\
1963 & 193 & 9.9 & 11.6 & 3.0 & 3.1 & 81 \\
1964 & 182 & 9.1 & 14.5 & 2.7 & 3.6 & 82 \\
1965 & 190 & 9.0 & 12.5 & 2.7 & 3.5 & 72 \\
& & & & & & 85 \\
1966 & 172 & 10.9 & 12.3 & 2.8 & 2.7 & 76 \\
1967 & 210 & 10.4 & 10.6 & 2.8 & 3.3 & 89 \\
1968 & 176 & 9.2 & 12.6 & 2.8 & 3.2 & 3.2 \\
1969 & 145 & 9.7 & 12.5 & 2.8 & 3.2 & \\
\hline
\end{tabular}

09260000 Little Snake River near Lily, Colo. ${ }^{3,4}$ (site $Y-1$ )

\begin{tabular}{lllllll}
\hline 1976 & 160 & 9.2 & 10.6 & 2.8 & 1.9 & 89 \\
1977 & 189 & 9.8 & 8.4 & 2.8 & 2.3 & 80 \\
\hline
\end{tabular}

IInstantaneous daily values, 1951-73 water years; daily mean values, 1976-77 water years.

2 Instantaneous daily values.

${ }^{3}$ Not included in the time-trend analysis.

${ }^{4}$ Daily mean values. 


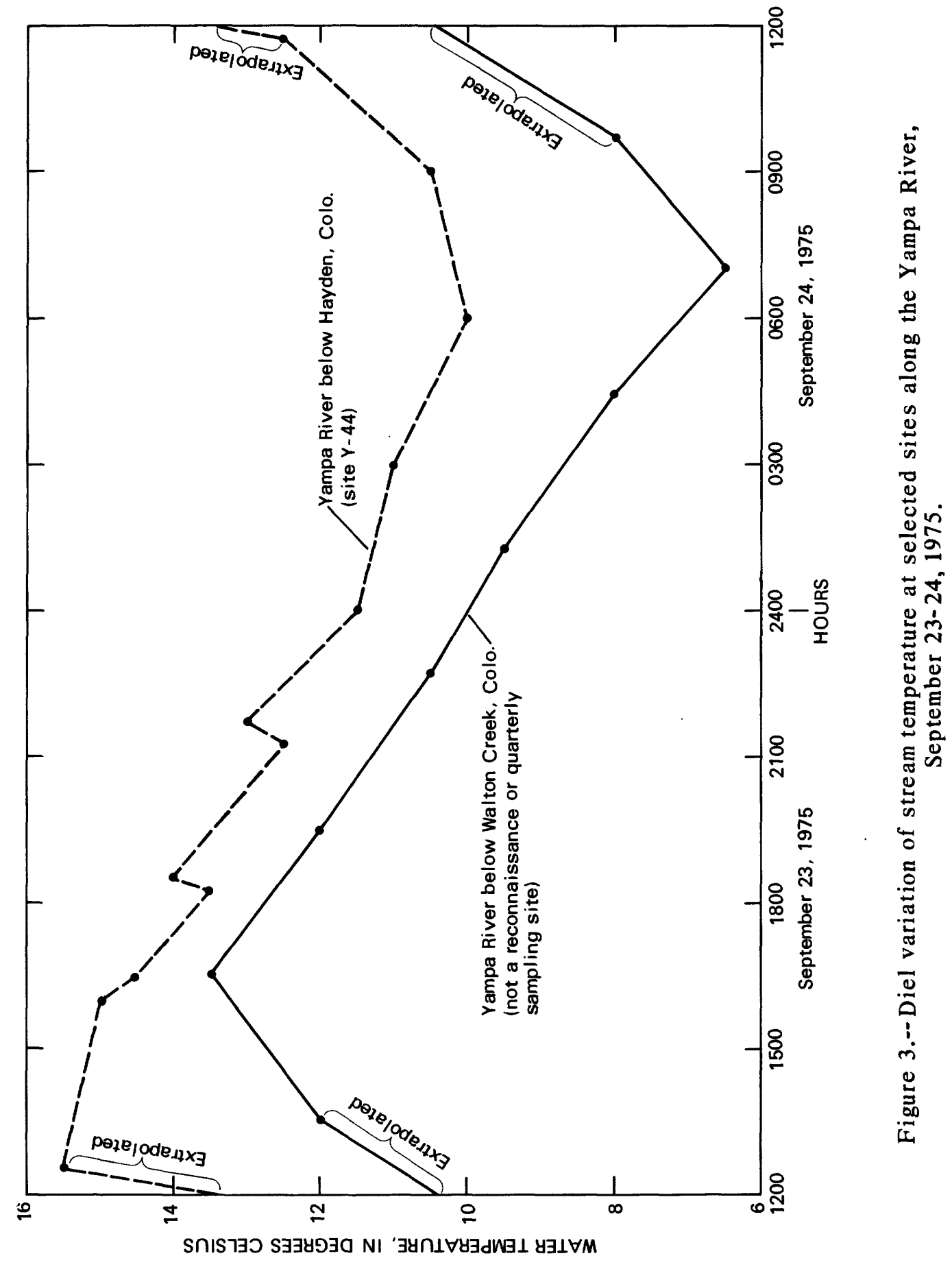


Stream-temperature data have been collected by Stearns-Roger, Inc. (written commun., 1976), on the Yampa River upstream from the water intake for the Hayden Powerplant (fig. 1). This site is comparable to the U.S. Geological Survey's station 09244410, Yampa River below diversion, near Hayden, Colo. (site $\mathrm{Y}-47)$. Harmonic analysis of the data collected by Stearns-Roger, Inc., from March 10 to December 30, 1975, resulted in the coefficients given in table 3 .

To assess the effect of measuring stream temperatures at less than daily frequencies on the results of the harmonic analysis, successively smaller subsets of the data shown in the top row of each section of table 3 were selected and analyzed. The results are shown in rows 2 through 7 of each section of table 3; they indicate minimal loss of information in terms of seasonal stream-temperature characterization. This supports a conclusion reached earlier by Gilroy and Steele (1972) and by Shampine (1977), and shows that relatively few measurements evenly spaced during a year will provide adequate estimates of the annual harmonic-temperature coefficients.

The results of the harmonic analysis applied to intermittent streamtemperature data collected from 1960 through 1975 at 34 U.S. Geological Survey stream-gaging sites are summarized in table 4 . The absence of time trends in the stream-temperature characteristics of these sites was assumed, and temperature data for several years were composited for each site. Intermittent stream temperatures generally are measured randomly during daylight hours and are subject to the same bias indicated for instantaneous daily stream temperatures (p. 10). Harmonic-analysis results for the five sites where intermittent temperature measurements are made by the Colorado Department of Health (see p. 5) are included in table 4 for comparison.

A general downstream increase in harmonic-mean temperature was noted for both the Yampa River (sites $Y-76, Y-64, Y-47$, and $Y-17$, fig. 1 and table 4) and the Little Snake River (sites $Y-12, Y-8, Y-2$, and $Y-1, f i g .1$ and table 4). The harmonic-temperature coefficients for the U.S. Geological Survey sites, which provide a general areal characterization of seasonal stream-temperature variations in the basin, were correlated with selected basin characteristics to see if regional patterns were discernible. For example, plots of the harmonic-mean temperature, amplitude, and phase angle versus altitude at each site are given on figure 4. The lines defined by the linear least-squares regression equations all show a general inverse correlation between the variables, the scatter generally being greater at higher altitudes. Harmonic-mean temperature is related to altitude according to the equation:

$$
M=20.8-0.0022 \cdot(\text { altitude, in feet) }
$$

Amplitude and phase angle, on the other hand, can be estimated effectively from average values of amplitude $(\bar{A})$ and phase angle $(\bar{C})$, as indicated by comparison of the standard error of estimate of the regression line with the standard deviation (fig. 4). 
Table 3.--Farmonic analysis of daily minimum and maximum stream temperatures near station 09244410, Yampa River below diversion, near Hayden, Colo. (near site Y-47), March 10 to December 30, 1975

[Data from Stearns-Roger, Inc., written commun., 1976]

\begin{tabular}{cccccc}
\hline $\begin{array}{c}\text { Number of } \\
\text { measure- } \\
\text { ments }\end{array}$ & $\begin{array}{c}\text { Mean } \\
\left({ }^{\circ} \mathrm{C}\right)\end{array}$ & $\begin{array}{c}\text { Amplitude } \\
\left({ }^{\circ} \mathrm{C}\right)\end{array}$ & $\begin{array}{c}\text { Phase } \\
\text { angle } \\
(\text { radians })\end{array}$ & $\begin{array}{c}\text { Standard } \\
\text { error of } \\
\text { estimate } \\
\text { of mean } \\
\left({ }^{\circ} \mathrm{C}\right)\end{array}$ & $\begin{array}{c}\text { Percentage } \\
\text { of }\end{array}$ \\
\hline
\end{tabular}

Daily minimum temperature

\begin{tabular}{rrrrrr}
\hline 233 & 6.9 & 8.9 & 4.1 & 2.3 & 83 \\
117 & 7.0 & 8.6 & 4.1 & 2.5 & 80 \\
77 & 6.6 & 9.1 & 4.1 & 2.1 & 86 \\
35 & 7.5 & 7.8 & 4.0 & 3.5 & 65 \\
16 & 6.4 & 9.7 & 4.1 & 2.3 & 85 \\
11 & 7.3 & 8.2 & 4.1 & 1.7 & 90 \\
7 & 6.7 & 10.1 & 4.1 & 2.7 & 81 \\
\hline
\end{tabular}

Daily maximum temperature

\begin{tabular}{rrrrrr}
\hline 237 & 7.8 & 10.7 & 4.1 & 2.4 & 87 \\
117 & 7.6 & 10.9 & 4.1 & 2.2 & 89 \\
78 & 8.1 & 10.2 & 4.0 & 2.7 & 83 \\
36 & 7.8 & 10.9 & 4.1 & 2.4 & 88 \\
16 & 7.7 & 10.8 & 4.1 & 1.8 & 92 \\
11 & 7.7 & 10.5 & 4.0 & 2.5 & 87 \\
7 & 7.6 & 11.0 & 4.0 & 2.4 & 97 \\
\hline
\end{tabular}

${ }^{\text {I All }}$ available data were used in the top row of each section; the effect of using fewer data is shown in successive rows. The data used were (beginning with the second row of each section) every other value, every $3 \mathrm{~d}$ value, every 7 th value, every 15 th value, every $22 \mathrm{~d}$ value, and every 29 th value.

${ }^{2}$ This assumes an annual increment beginning on January 1 and ending on December 31 . 


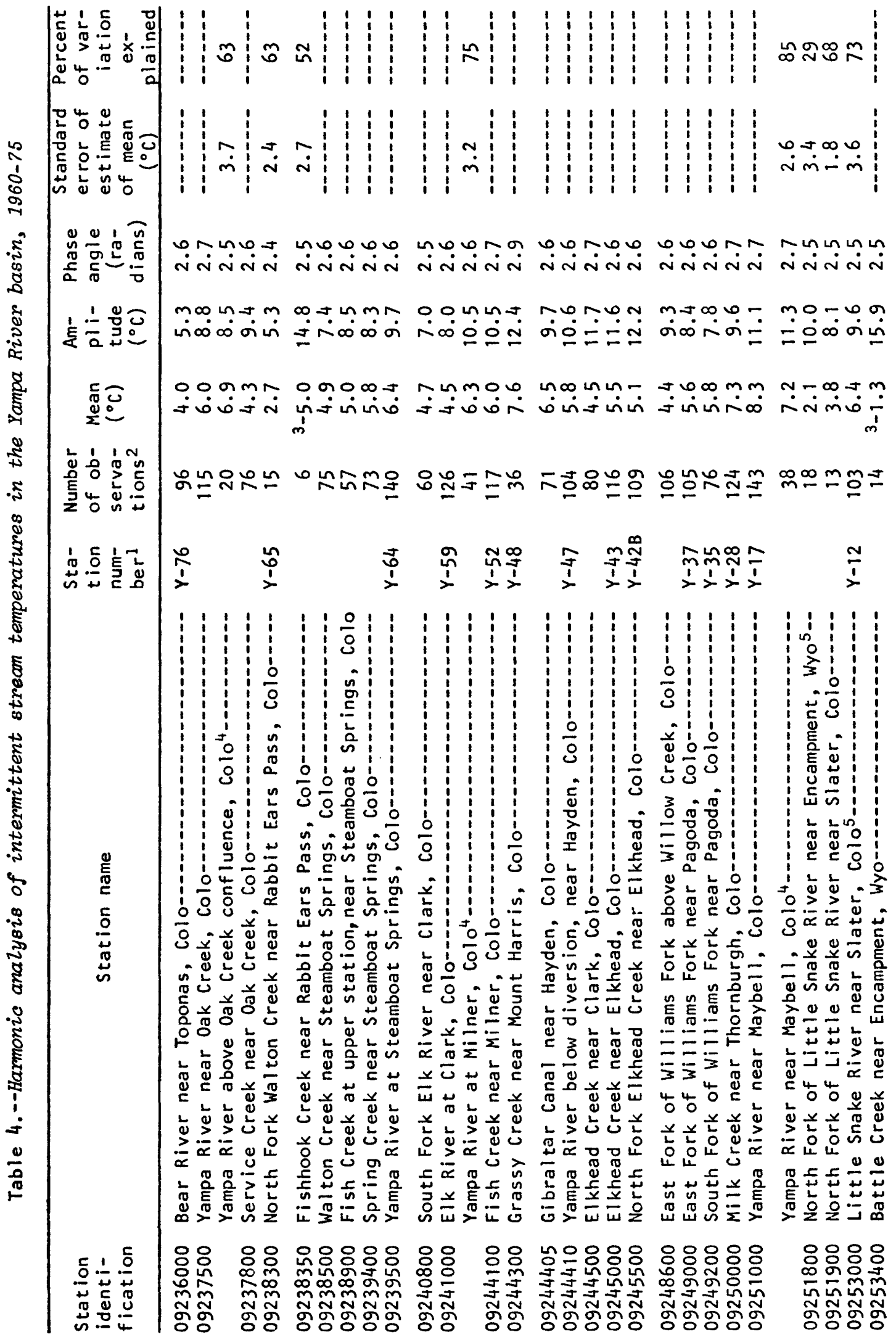




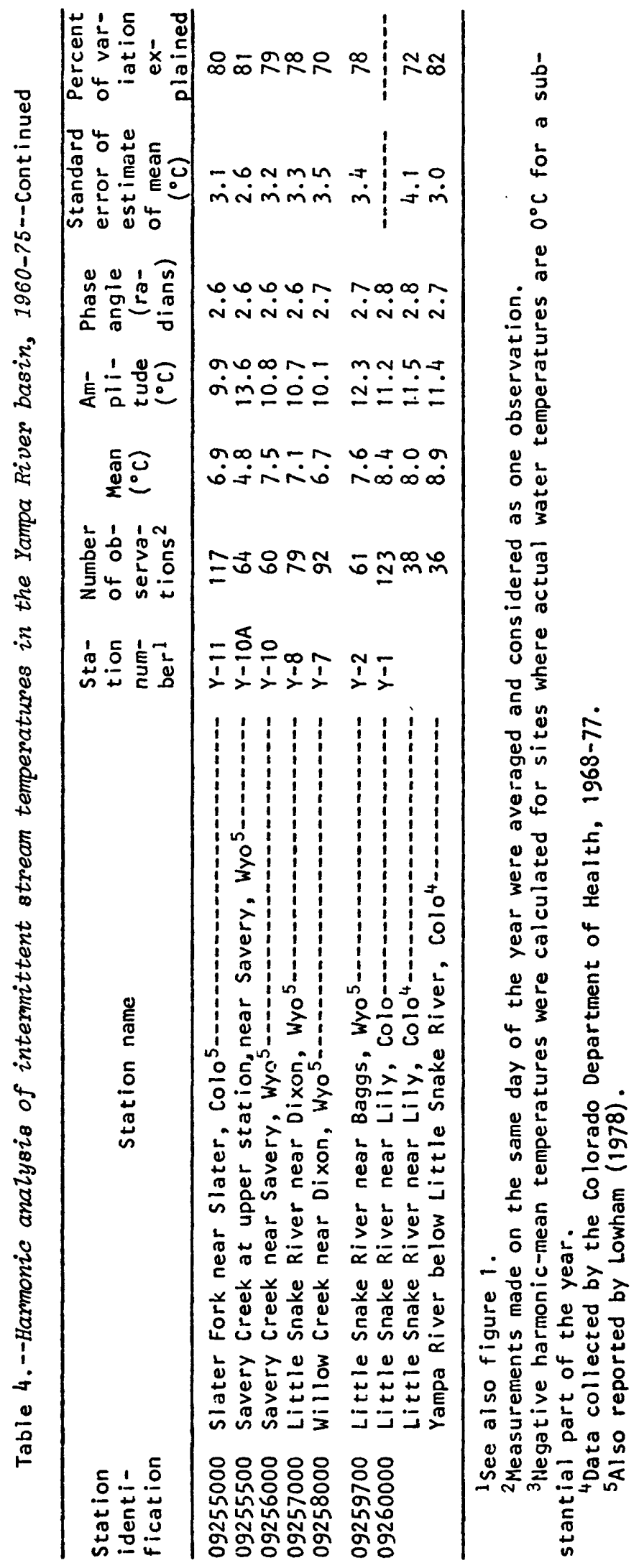


ALTITUDE, IN METERS ABOVE MEAN SEA LEVEL
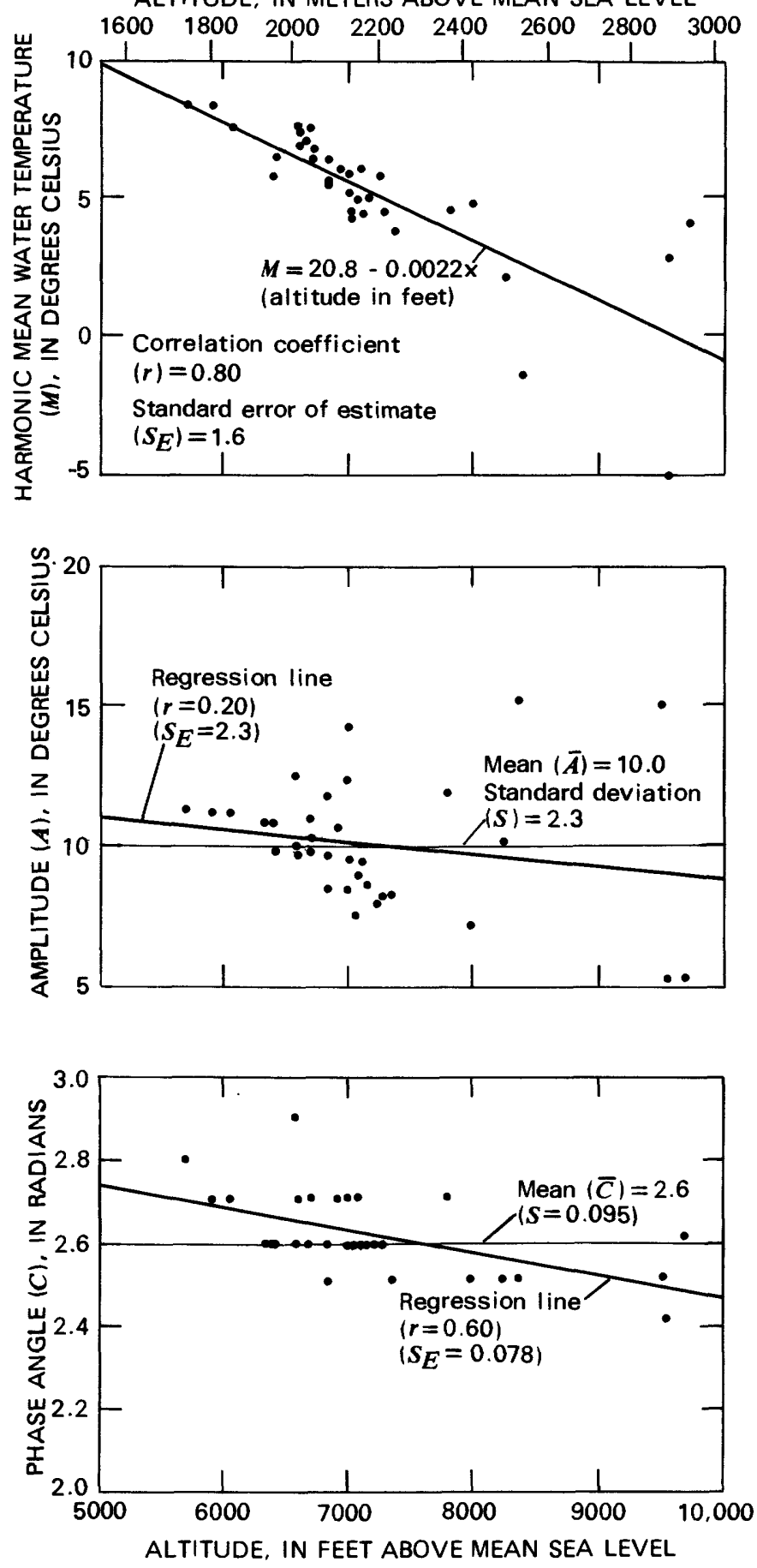

Figure 4.--Relationships between stream-temperature harmonic-analysis coefficients and altitude for streams in the Yampa River basin, 1960-75. 
Similar regional stream-temperature analyses have been reported for other areas of the United States (Steele and Dyar, 1974; Shampine, 1977; Lowham, 1978; Clement, 1978; Limerinos, 1978). Lowham's regression equation for estimating stream temperatures in the Green River basin, southwestern Wyoming,

$$
M=19.5-0.0019 \cdot(\text { altitude, in feet), }
$$

is similar to that used for the Yampa River basin (equation 2).

Regional analysis of stream temperatures may be used for detecting changes resulting from man's activities, even though predevelopment information may be sparse or lacking. For example, to assess potential effects of a coal-strip mine on stream temperatures in the Yampa River basin, several years of intermittent stream-temperature measurements downstream from the mine would be needed. Harmonic-temperature coefficients calculated from equation 1 (p. 10) could then be compared to predevelopment coefficients estimated from the altitude of the site using the information given on figure 4. This has not been done in the present study because of a lack of time to collect sufficient stream-temperature data downstream from existing coal mines.

Because mountain streams typically undergo a diel variation in temperature during the summer (fig. 3), and because the sites visited during AugustSeptember 1975 were sampled randomly during daylight hours, it is very difficult to determine any conclusions regarding stream temperatures measured as part of the basinwide reconnaissance. One approach, however, is to compare measured temperatures to applicable water-quality standards.

Water-quality standards applicable to Colorado streams and lakes (Colorado Department of Health, 1977b) are presented in table 5. Throughout this report, values of water-quality variables are compared only to colorado standards. This was done, in part, to avoid confusion, as a number of differences exist between the Wyoming (Wyoming Department of Environmental Quality, 1978) and proposed Colorado standards. Also, in both the basinwide reconnaissance and the quarterly sampling program, relatively few stream sites were located in Wyoming (table 1).

The upper temperature limit for streams supporting cold-water biota in Colorado is $20^{\circ} \mathrm{C}$ (Celsius). Nine of the 82 measurements ( 11 percent) made during the basinwide reconnaissance exceeded this limit. The total range of stream temperatures observed during the reconnaissance was 9.0 to $25.5^{\circ} \mathrm{C}$; thus, none was greater than the upper $1 \mathrm{imit}$ of $30^{\circ} \mathrm{C}$ for streams supporting warm-water biota (table 5).

During the quarterly sampling program from December 1975 through AugustSeptember 1976, only 7 of 163 temperature measurements ( 4 percent) exceeded the $20^{\circ} \mathrm{C}$ limit. Three of these occurred in June 1976 , and four occurred during August-September 1976. Again, no recorded temperature was greater than $30^{\circ} \mathrm{C}$, as the range of stream temperature for the quarterly sampling program was 0 to $26.5^{\circ} \mathrm{C}$. All temperatures that exceeded the $20^{\circ} \mathrm{C} 1 \mathrm{imit}$ during both the basinwide reconnaissance and the quarterly sampling program appear to be due to natural causes. 


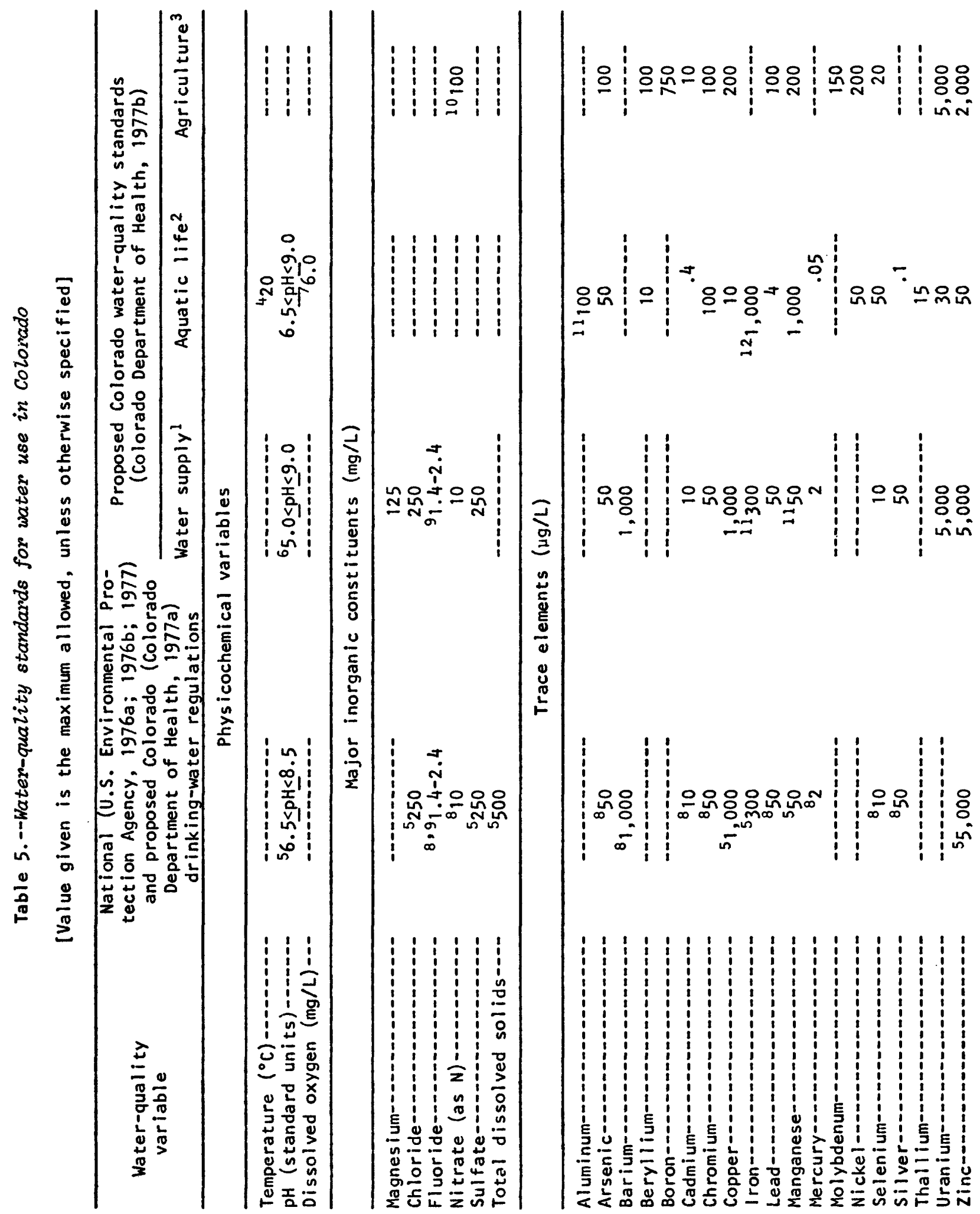




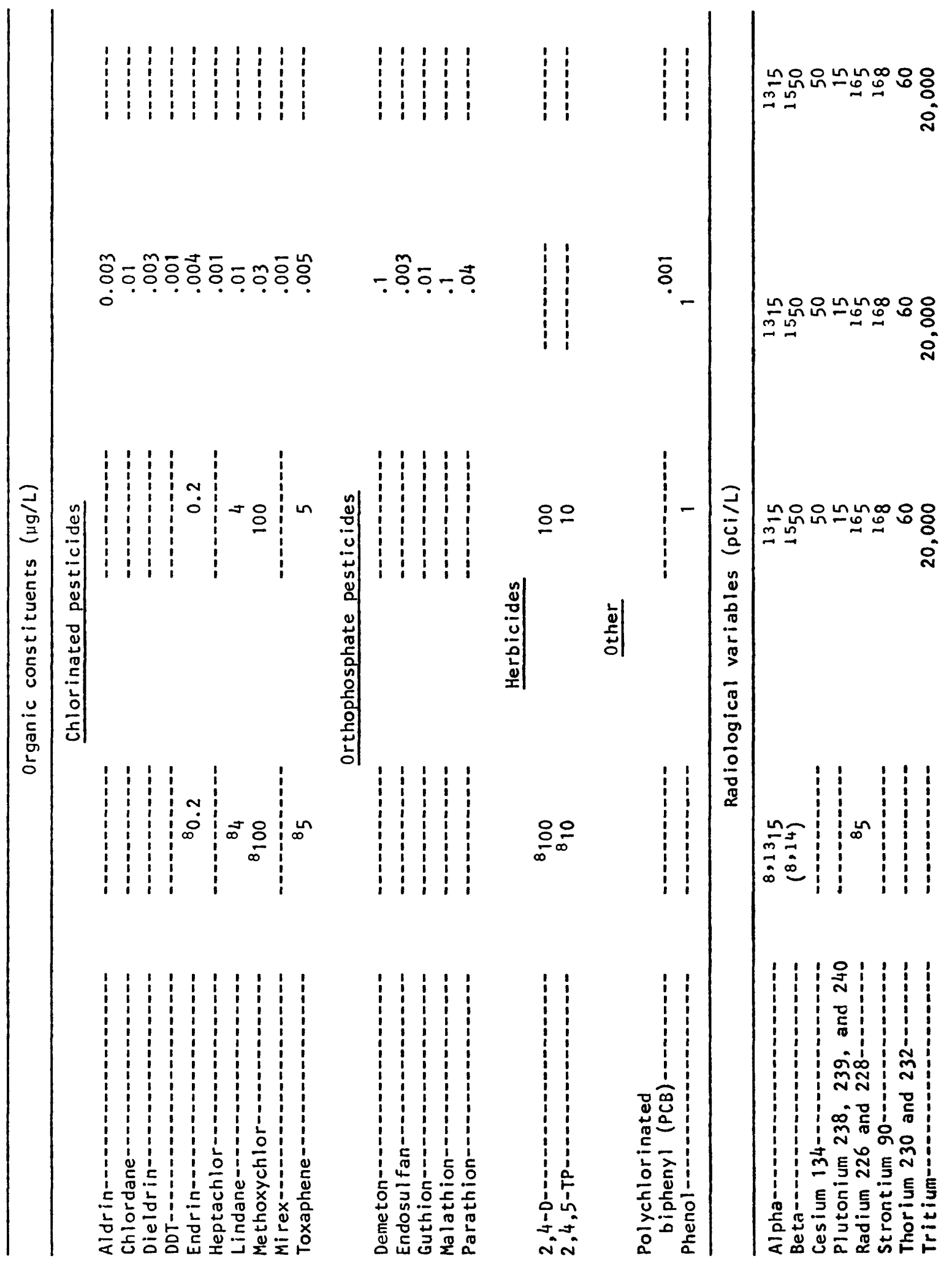




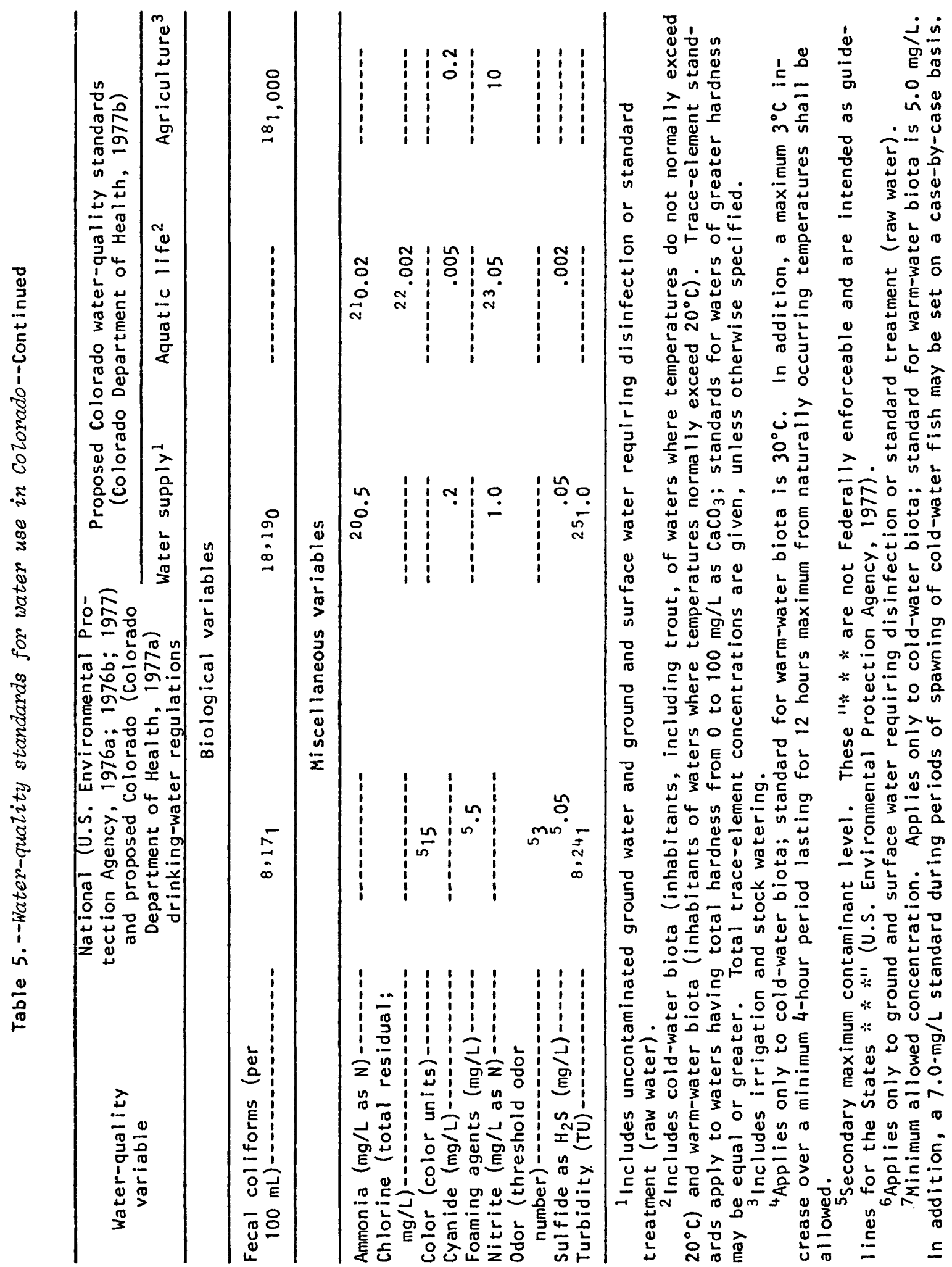




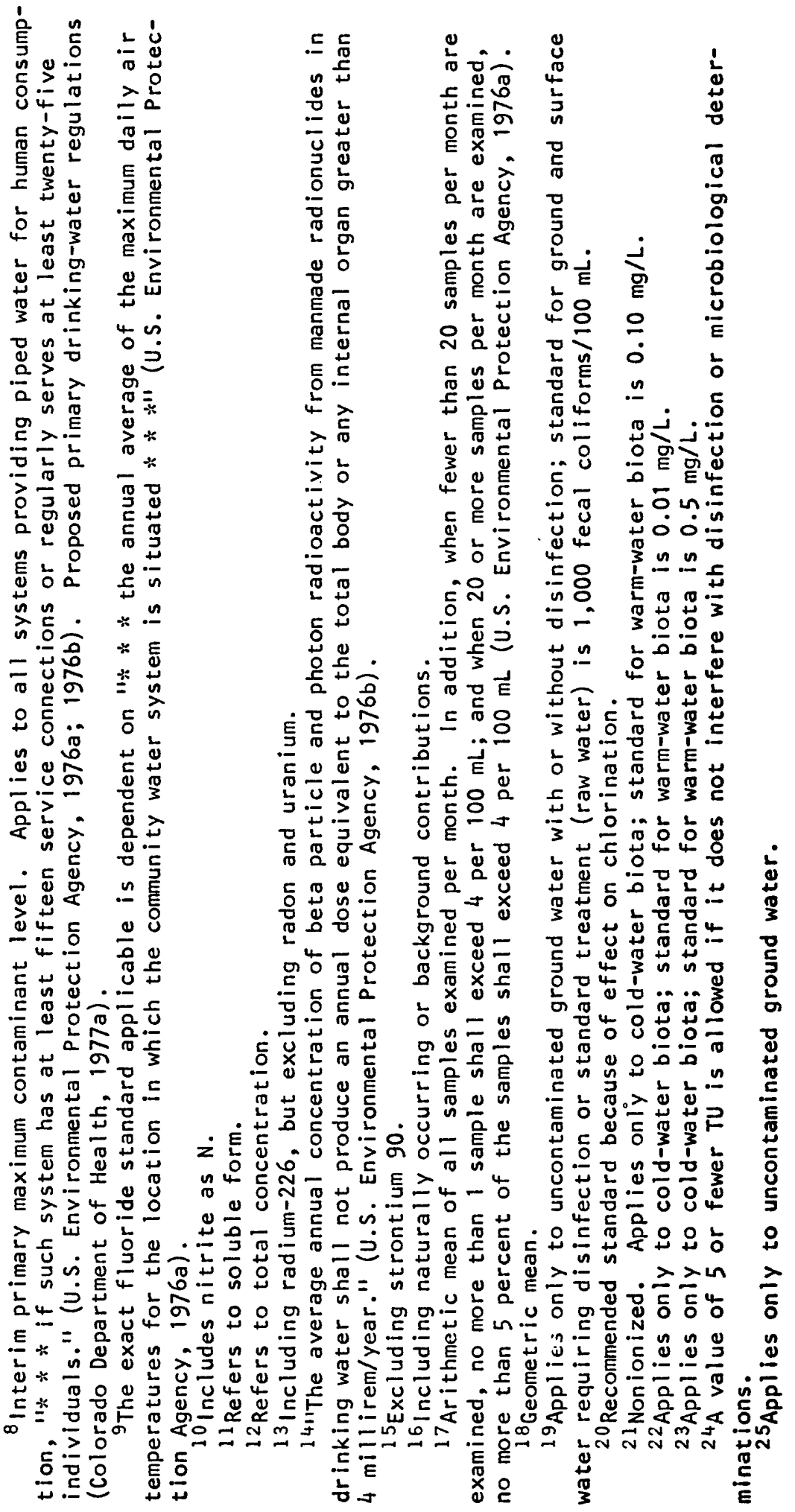


The altitude below which stream temperatures greater than the $20^{\circ} \mathrm{C} 1 \mathrm{imit}$ are expected can be estimated. The maximum stream temperature $\left(T_{M A X}\right)$ is given as:

$$
T_{M A X}=M+A \text {. }
$$

The TMAX of concern here is the $20^{\circ} \mathrm{C} l i m i t$. Because this temperature is never to be exceeded, it must, in fact, be measured as an instantaneous maximum daily value. To be consistent with this approach, $M$ and $A$ in equation 4 also must be functions of maximum daily values. In reality, regional data for $M$ and $A$ in the Yampa River basin probably reflect measured temperatures somewhere between the daily mean and the daily maximum value ( $p .10$ and 16), and do not strictly satisfy this requirement. However, the following example illustrates the principle involved.

In the Yampa River basin, $A$ is estimated from $\bar{A}$ (fig. 4 ) to be $10.0^{\circ} \mathrm{C}$. Substituting this value and $20^{\circ} \mathrm{C}$ for $T_{M A X}$ into equation 4 yields a value of $10.0^{\circ} \mathrm{C}$ for $M$. Substituting this value of $M$ into equation 2 yields an estimate of $4,950 \mathrm{ft}(1,510 \mathrm{~m})$. The lowest point in the Yampa River basin is $5,100 \mathrm{ft}(1,600 \mathrm{~m})$ at the mouth of the Yampa River, so theoretically stream temperatures of $20^{\circ} \mathrm{C}$ or greater should not be expected. It must be remembered, however, that the uncertainties involved in estimating $M$ and $A$ have not been considered in this analysis. These uncertainties easily account for the recorded temperatures that were greater than $20^{\circ} \mathrm{C}$.

\section{Major Inorganic Constituents and Specific Conductance}

Concentrations of major inorganic constituents frequently are correlated with specific conductance. In this study, linear, bivariate, least-squares regression equations relating major inorganic constituents to specific conductance (table 6) were developed on a regional basis using the data published by lorns, Hembree, Phoenix, and Oakland (1964). Site-specific regression equations for the Yampa River near Maybell, Colo., and for the Little Snake River near Lily, Colo. (table 7), were developed based on the data described on page 4. Two different time periods were used for the sitespecific regressions: One encompasses the entire period of record at the time of the analysis (1951-75 water years); whereas, the other (1966-72 water years) was that used by Steele, Gilroy, and Hawkinson (1974). The latter, shorter period of record was chosen to eliminate any time trends that might be affecting water quality.

The appropriate site-specific regression equations (table 7) were applied to daily specific-conductance records available for the Yampa River near Maybell and the Little Snake River near Lily. For comparison purposes, the historical regional regression equations (table 6) also were applied at each site. Using a computer program documented by Steele (1973), daily loads and concentrations were estimated for the various chemical constituents, and monthly and annual discharge-weighted and time-weighted values were determined. 
Table 6.--Regional regression relationships for major inorganic constituents in streams of the Yampa River basin, as computed from historic data

[Predicted variable, in milligrams per liter=a+b-(specific conductance, in micromhos per centimeter at $25^{\circ} \mathrm{C}$ ); data from lorns, Hembree, Phoenix, and Oakland (1964)]

\begin{tabular}{|c|c|c|c|c|c|c|c|}
\hline \multirow[t]{2}{*}{ Predicted variable } & \multirow[t]{2}{*}{$\begin{array}{l}\text { Inter- } \\
\text { cept } \\
\text { (a) }\end{array}$} & \multirow[t]{2}{*}{$\begin{array}{l}\text { Slope } \\
\text { (b) }\end{array}$} & \multirow{2}{*}{$\begin{array}{l}\text { Standard } \\
\text { error of } \\
\text { estimate } \\
\text { of } \\
\text { predicted } \\
\text { variable } \\
\end{array}$} & \multirow{2}{*}{$\begin{array}{l}\text { Corre- } \\
\text { lation } \\
\text { coeffi- } \\
\text { cient } \\
(r)\end{array}$} & \multirow[t]{2}{*}{$\begin{array}{l}\text { Number } \\
\text { of data } \\
\text { pairs }\end{array}$} & \multicolumn{2}{|c|}{$\begin{array}{l}\text { Range of specific } \\
\text { conductance } \\
\text { (micromhos per } \\
\text { centimeter at } 25^{\circ} \mathrm{C} \text { ) }\end{array}$} \\
\hline & & & & & & Minimum & Maximum \\
\hline $\begin{array}{l}\text { Calcium } \\
\text { Magnesium } \\
\text { Sodium } \\
\text { Potassium } \\
\text { Sodium and potassium }\end{array}$ & $\begin{array}{r}7.06 \\
-2.43 \\
-1.16 \\
.197 \\
-4.93\end{array}$ & $\begin{array}{l}0.0860 \\
.0465 \\
.0426 \\
.00758 \\
.0741\end{array}$ & $\begin{array}{l}7.27 \\
3.73 \\
2.35 \\
.24 \\
8.52\end{array}$ & $\begin{array}{r}0.90 \\
.91 \\
.92 \\
.97 \\
.86\end{array}$ & $\begin{array}{r}62 \\
62 \\
14 \\
3 \\
57\end{array}$ & $\begin{array}{r}20 \\
20 \\
59 \\
116 \\
20\end{array}$ & $\begin{array}{l}831 \\
831 \\
219 \\
308 \\
831\end{array}$ \\
\hline $\begin{array}{l}\text { Total hardness } \\
\text { Bicarbonate } \\
\text { Sulfate } \\
\text { Chloride } \\
\text { Calculated dissolved }\end{array}$ & $\begin{array}{l}7.84 \\
14.6 \\
-13.0 \\
-1.98\end{array}$ & $\begin{array}{l}.404 \\
.406 \\
.182 \\
.0277\end{array}$ & $\begin{array}{l}21.1 \\
22.2 \\
13.4 \\
8.50\end{array}$ & $\begin{array}{l}.96 \\
.95 \\
.92 \\
.51\end{array}$ & $\begin{array}{l}62 \\
96 \\
87 \\
73\end{array}$ & $\begin{array}{l}20 \\
17 \\
17 \\
17\end{array}$ & $\begin{array}{l}831 \\
831 \\
831 \\
229\end{array}$ \\
\hline solids & 4.48 & .586 & 5.81 & .99 & 5 & 59 & 308 \\
\hline $\begin{array}{l}\text { Measured dissolved } \\
\text { solids } \\
\text { Nitrate-N } \\
\text { Silica }\end{array}$ & $\begin{array}{c}7.35 \\
5.104 \\
511.3\end{array}$ & $\begin{array}{c}.628 \\
-\end{array}$ & $\begin{array}{c}10.0 \\
6.0927 \\
64.64\end{array}$ & $\begin{array}{r}.99 \\
-.--\end{array}$ & $\begin{array}{l}35 \\
57 \\
55\end{array}$ & $\begin{array}{l}39 \\
20 \\
20\end{array}$ & $\begin{array}{l}831 \\
831 \\
831\end{array}$ \\
\hline
\end{tabular}

lData for 96 samples collected at 34 sites were used in this analysis.

${ }^{2}$ Range of specific-conductance values for analyses used to determine the regression equation.

${ }^{3}$ Due to randomness of the data, application of the equation at the lower end of the specific-conductance range may result in negative estimates for the predicted variable.

${ }^{4}$ The alternative model, predicted value = mean value, is given because of small values of $r$.

5 Mean.

${ }^{5}$ Standard deviation.

Simulation results for annual mean discharge-weighted concentrations of dissolved solids for the Yampa River near Maybell were almost identical using the three equations (regional, and site-specific for 1951-75 and 1966-72) applicable to this site (fig. 5). Moreover, the fit to the observed values used here is good through 1970 ( $\mathrm{fig}$. 5). (The term "observed values" is used here to describe annual mean discharge-weighted concentrations calculated from measurements of dissolved solids and stream discharge.) Deviations since 1970 may be attributed largely to changing from composited to monthly samples for determining annual mean concentrations.

Agreement among the three applicable equations and the fit to the observed data generally is not as good for individual chemical constituents as for dissolved solids. This is exemplified by the observed and simulated 


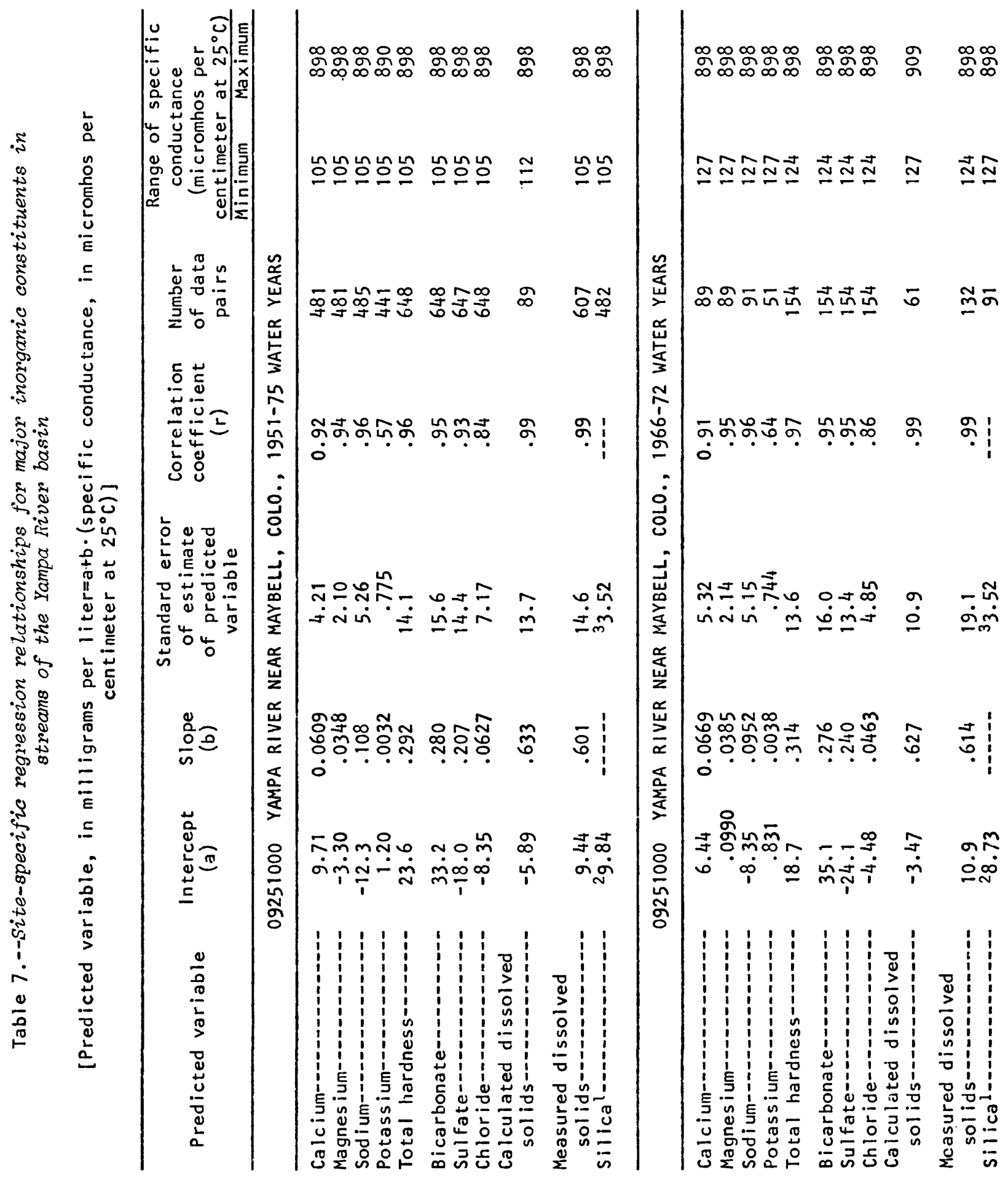




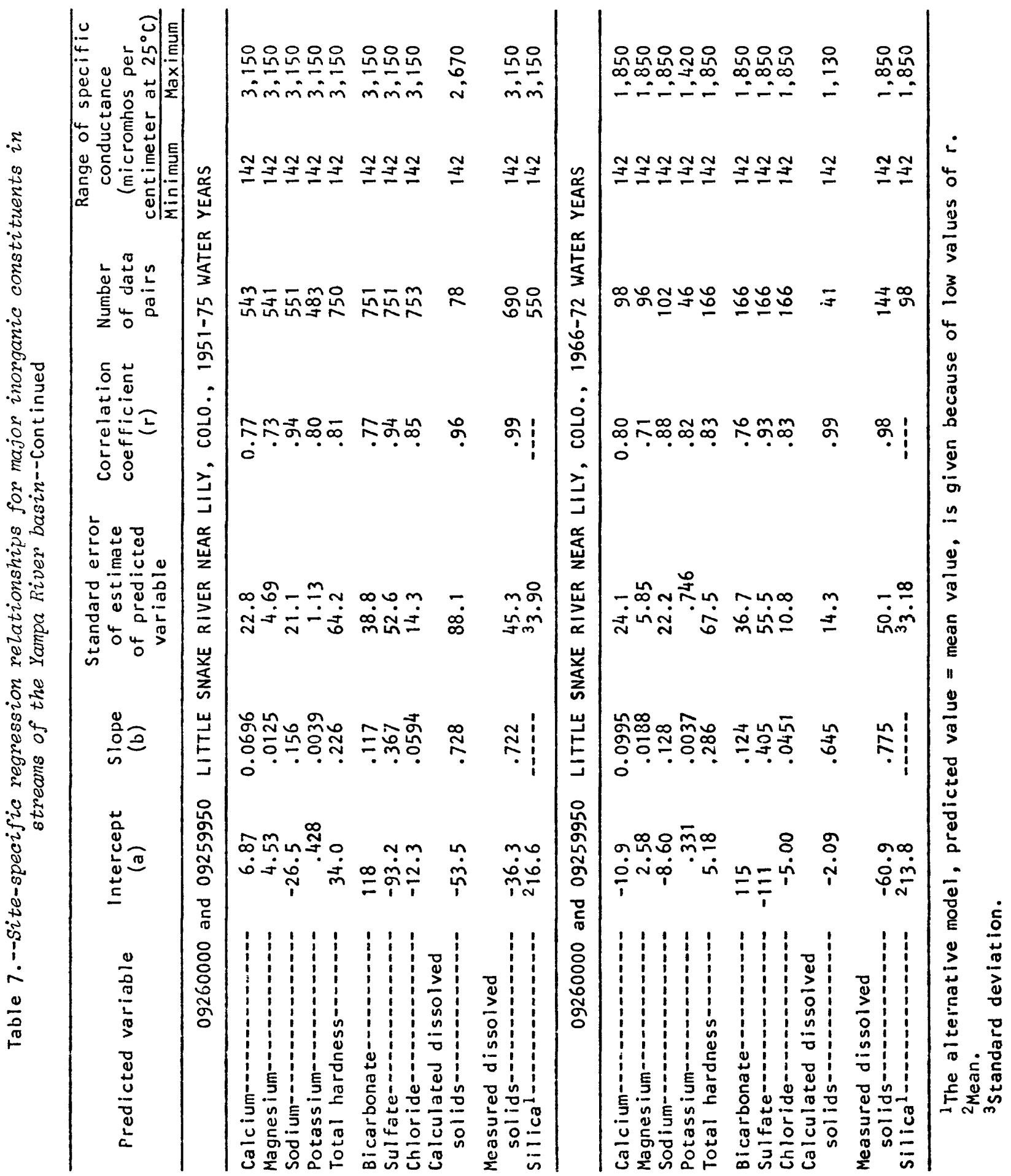




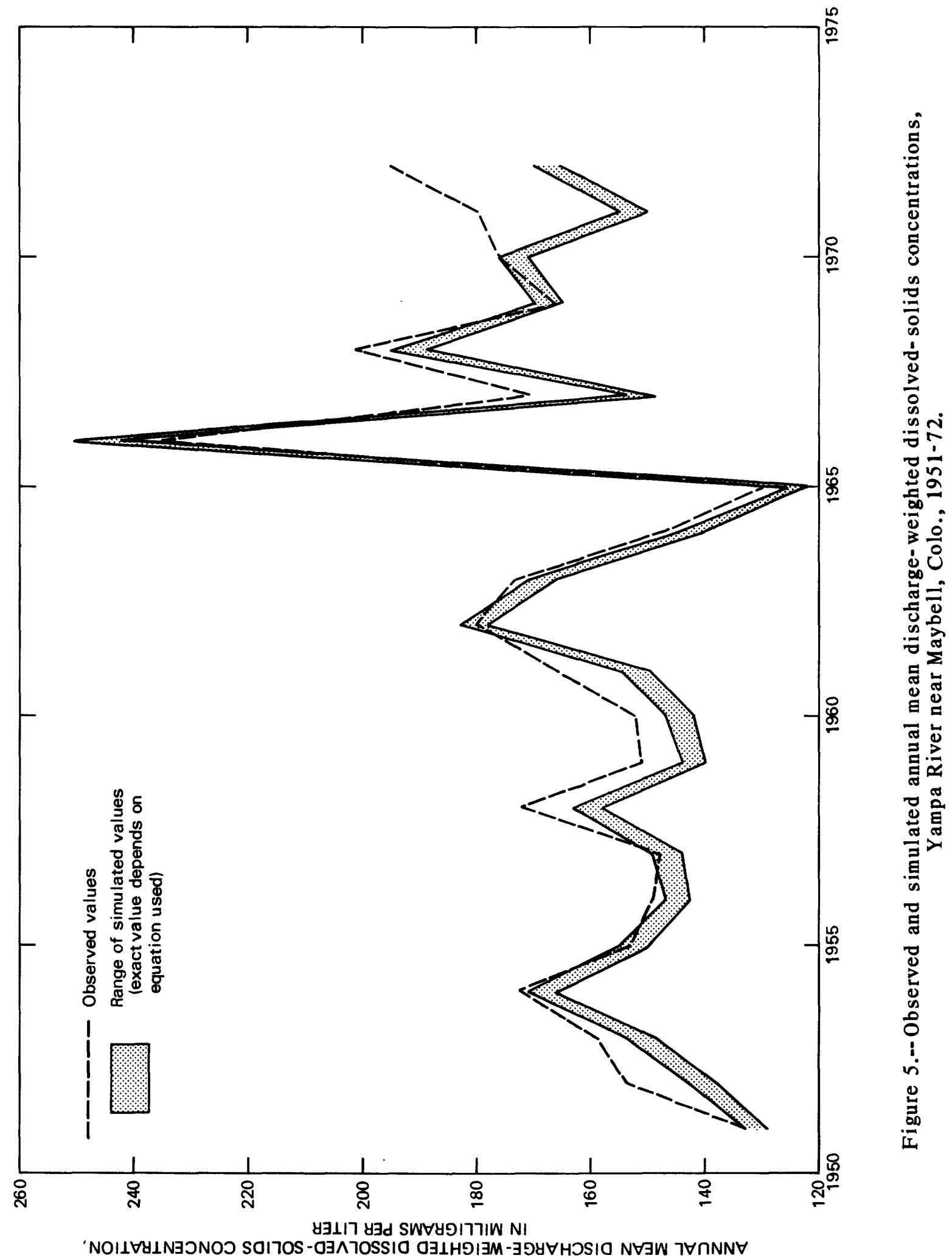


calcium concentrations for the Yampa River near Maybell, Colo. (fig. 6). One possible explanation for this involves nonhomogeneity in the watershed. The Yampa River subbasin upstream from the site near Maybell is $3,410 \mathrm{mi}^{2}$ $\left(8,830 \mathrm{~km}^{2}\right)$ and the geology and $\mathrm{climate}$ vary considerably. Waters originating in different parts of the Yampa River subbasin can contain considerably different proportions of individual cations and anions but still have relatively similar ratios of dissolved solids to specific conductance. Natural seasonal variations in the sources of the water would be expected to affect the relationships between individual chemical constituents and specific conductance more than the relationship between dissolved solids and specific conductance. Irrigation return flows, which are most important from May through September, can concentrate some chemical constituents relative to others (Hem, 1970, p. 330) and would be expected to produce a similar effect.

The relation between observed and simulated dissolved-solids concentrations for the Little Snake River near Lily (fig. 7) is not as good as the relation obtained for the Yampa River near Maybell. This may be due partly to lesser homogeneity in the Little Snake River subbasin (site-specific relationships) and partly to the fact that only about one-third of the sites sampled by lorns, Hembree, Phoenix, and Oakland (1964) were in the Little Snake River subbasin (regional relationship).

Using actual streamflow and water-quality records for the sites on the Yampa River near Maybell and the Little Snake River near Lily, time-trend analyses were made for the annual mean values of specific conductance at each site, adjusting for streamflow effects. This procedure is documented by Steele, Gilroy, and Hawkinson (1974) and uses Kendall's Tau nonparametric statistical test on each ranked, annual time series (Conover, 1971). Using data for the 1951-72 water years and a significance level of 0.01 , an increase in specific conductance of 14 percent was determined for the Yampa River (Steele and others, 1974, table 9, p. 67); however, no significant change was determined for the Little Snake River using data for the 1951-69 water years. The trend in increasing specific conductance for the Yampa River is attributed to increasing use of surface water for agricultural and municipal purposes. Analysis of data for the 1951-63 water years showed no significant changes at either of these two sites (Blackman and others, 1973, table 111$)$.

Major inorganic constituents were analyzed in samples collected during the August-September 1975 reconnaissance at the 26 sites shown on figure 8 , and regional regression equations relating major inorganic constituents to specific conductance were developed from these data (table 8). Graphic depiction of the equations indicates that the regional regression relationships calculated from the 26 analyses are similar to those calculated from historic data (table 6 ). The regional regression relationships allow estimation of concentrations of major inorganic constituents throughout the basin from the rather simple measurement of specific conductance. (Information on the precision of major inorganic constituents analyzed during the AugustSeptember 1975 reconnaissance is given in table 17 in the Supplemental Information section at the back of this report.) 


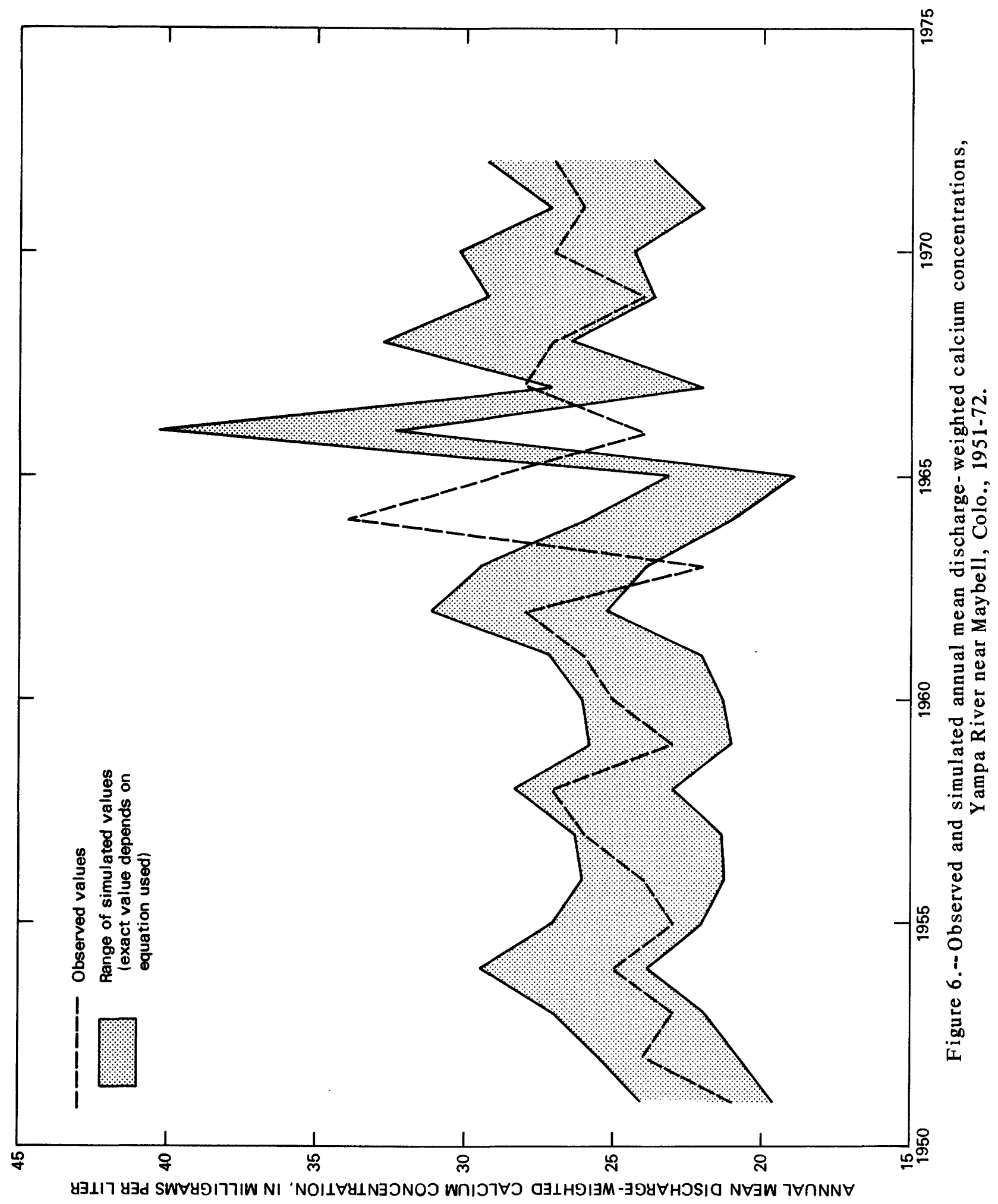




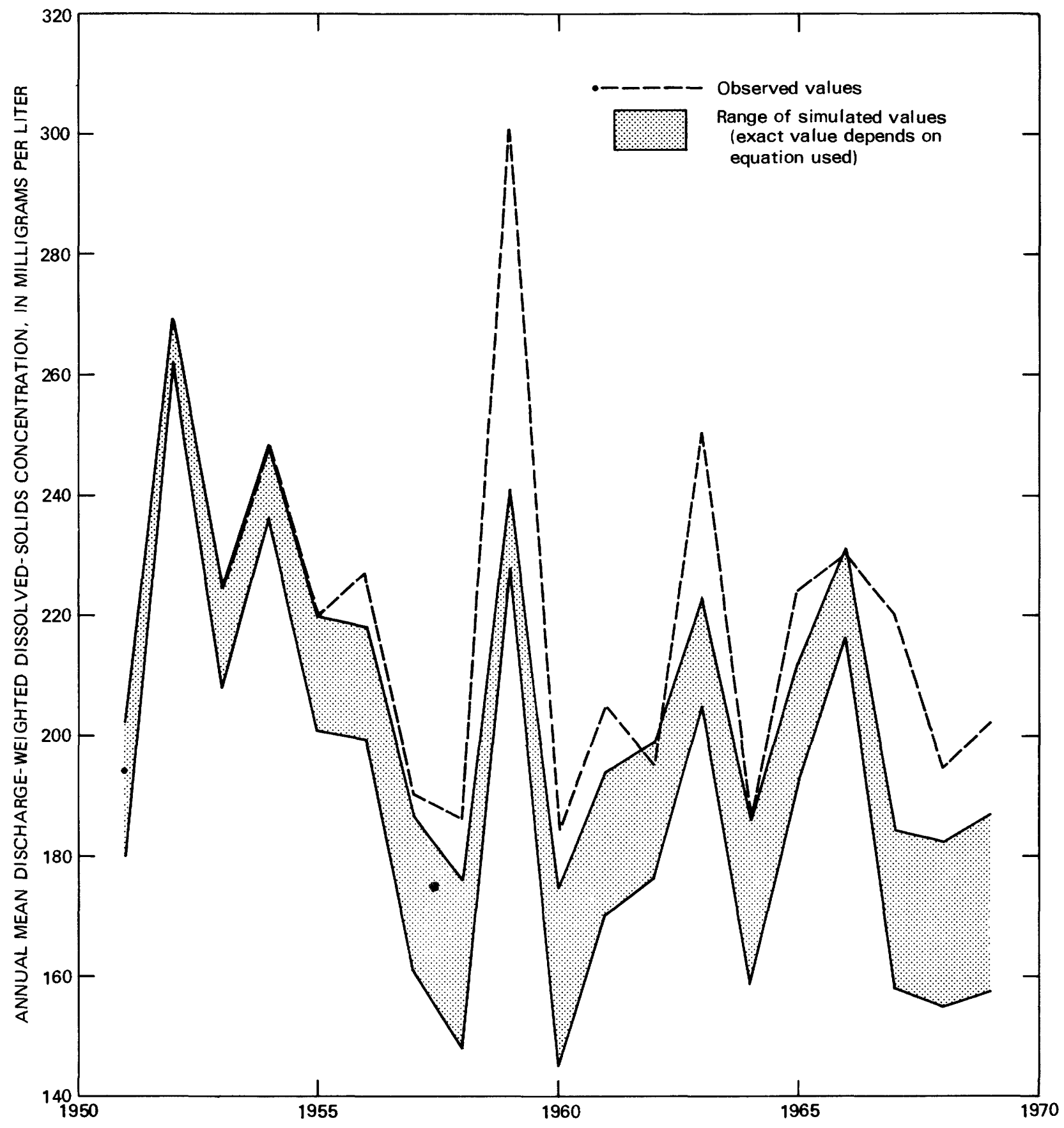

Figure 7.-- Observed and simulated annual mean discharge-weighted dissolved-solids concentrations, Little Snake River near Lily, Colo., 1951-69. 


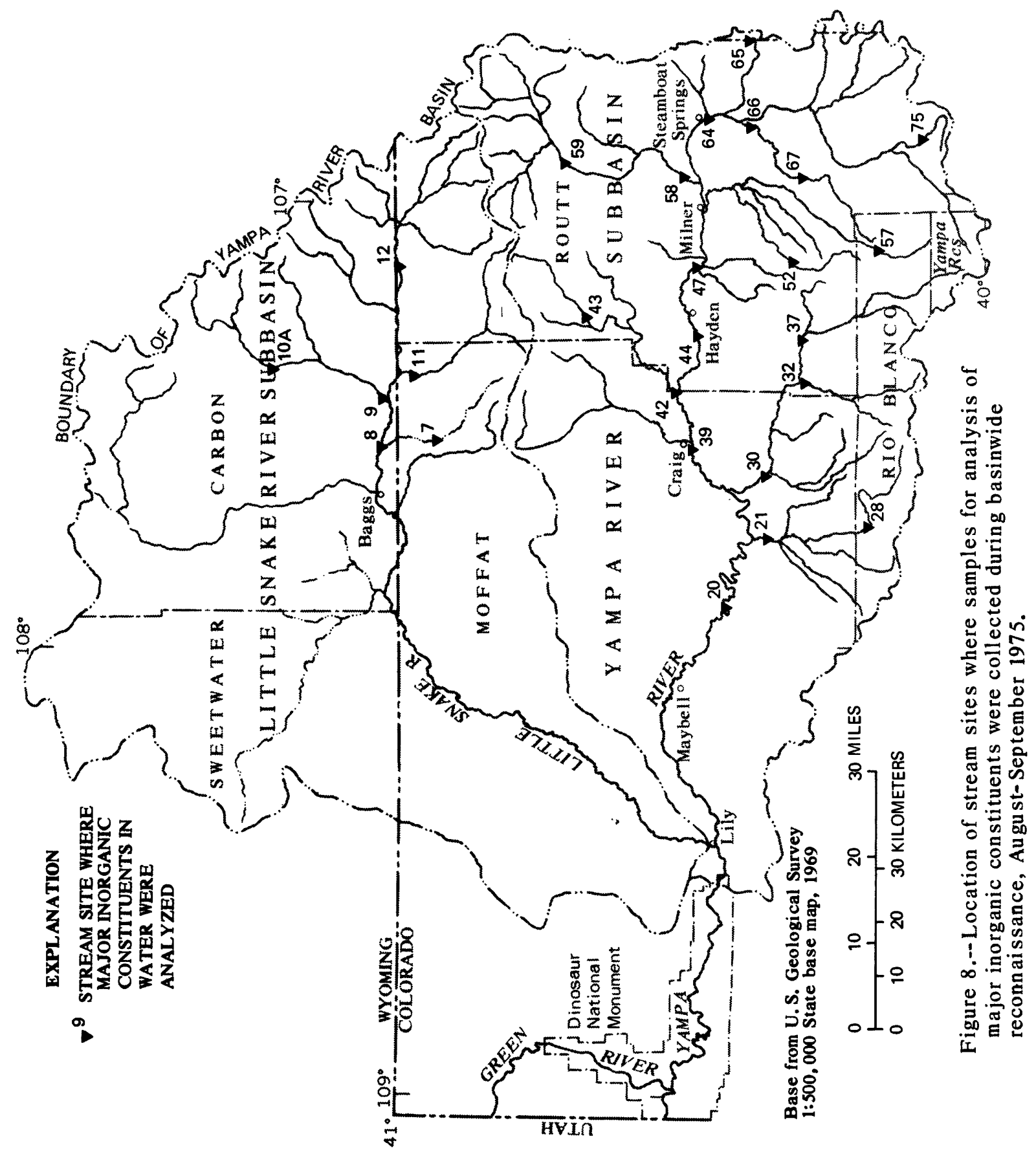


Table 8.--Regional regression relationships for major inorganic constituents in streams of the Yampa River basin, as computed from data collected during the basinwide reconnaissance, August-September 1975

[Predicted variable, in milligrams per liter=a+b. (specific conductance, in micromhos per centimeter at $25^{\circ} \mathrm{C}$ ), where specific conductance ranges from 65 to 950 micromhos per centimeter for 26 determinations]

\begin{tabular}{|c|c|c|c|c|}
\hline Predicted variable & $\begin{array}{c}\text { Intercept } \\
\text { (a) }\end{array}$ & $\begin{array}{l}\text { Slope } \\
\text { (b) }\end{array}$ & $\begin{array}{c}\text { Standard error } \\
\text { of estimate } \\
\text { of predicted } \\
\text { variable } \\
\end{array}$ & $\begin{array}{l}\text { Corrrelation } \\
\text { coefficient } \\
(r)\end{array}$ \\
\hline $\begin{array}{l}\text { Calcium } \\
\text { Magnes ium } \\
\text { Sod i um } \\
\text { Potass ium } \\
\text { Total hardnesss }\end{array}$ & $\begin{array}{l}4.36 \\
-7.25 \\
-.0758 \\
-.830 \\
-18.8\end{array}$ & $\begin{array}{l}0.0962 \\
.0632 \\
.0415 \\
.00370 \\
.502\end{array}$ & $\begin{array}{l}8.63 \\
5.97 \\
7.49 \\
.554 \\
25.8\end{array}$ & $\begin{array}{l}0.94 \\
.94 \\
.81 \\
.86 \\
.98\end{array}$ \\
\hline $\begin{array}{l}\text { Bicarbonate } \\
\text { Sulfatel } \\
\text { Chloride }\end{array}$ & $\begin{array}{l}28.8 \\
-45.5 \\
1.79 \\
3(3.82) \\
-16.0\end{array}$ & $\begin{array}{l}.348 \\
.283 \\
.00501 \\
(-.659\end{array}$ & $\begin{array}{c}29.3 \\
26.3 \\
2.57 \\
4(2.80) \\
17.9\end{array}$ & $\begin{array}{l}.95 \\
.94 \\
.44 \\
(--) \\
.99\end{array}$ \\
\hline $\begin{array}{l}\text { Fluoride } \\
\text { Silica } 5\end{array}$ & $\begin{array}{l}3.102 \\
3(.200) \\
310.6\end{array}$ & $(000241$ & $\begin{array}{l}.0687 \\
4(.0894) \\
45.36\end{array}$ & $\begin{array}{l}.66 \\
(---) \\
---\end{array}$ \\
\hline
\end{tabular}

${ }^{1}$ Due to randomness of the data, application of the equation at the lower end of the specific-conductance range may result in negative estimates for the predicted variable.

2 The alternative model, predicted value $=$ mean value, is given in parentheses because of small values of $r$.

3 Mean.

${ }^{4}$ Standard deviation.

${ }^{5}$ The alternative model, predicted value $=$ mean value, is given because of a small value of $r$. 
Stream-reach profiles of specific conductance for the Yampa and the Little Snake Rivers are shown on figure 9. Specific conductance in the Yampa River was measured downstream only to site $Y-0$ during the August-September 1975 reconnaissance. At this point, the river enters a steep-sided canyon in Dinosaur National Monument ( $f \mathrm{ig} .1$ ), and access to the lower reaches of the river is restricted until it enters the Green River. In August 1976, a reconnaissance of the lower Yampa River was conducted during low-flow conditions to assess the water quality of that part of the Yampa River in Dinosaur National Monument (Steele and others, 1978). Specific-conductance values at site $\gamma-0$ for the 2 years agreed quite well- -460 umhos (micromhos) for 1975 and 445 umhos for 1976--and the data for the two periods are believed by the authors to be comparable.

Most of the specific-conductance increase in the Yampa River occurs near the headwaters (fig. 9), where values change from 100 umhos or less to between 300 and 400 umhos in a $20-\mathrm{mi}(32-\mathrm{km})$ reach. Farther downstream, increases. from irrigation return flows and ground-water inflow are balanced by dilution from tributary inflow until the confluence with the Little Snake River. The Little Snake River near its mouth had a specific conductance of more than twice that of the Yampa River just upstream and caused the specific conductance of the Yampa River to increase by about 40 percent. In the 46-mi $(74-\mathrm{km})$ reach within Dinosaur National Monument, specific conductance increased by 50 umhos during the August 1976 reconnaissance, even though there are no major tributaries entering this reach. The dominant factor causing this increase is probably evaporation, as a net decrease in stream discharge of $18 \mathrm{ft}^{3} / \mathrm{s}\left(0.5 \mathrm{~m}^{3} / \mathrm{s}\right)$ was observed in this $46-\mathrm{mi}(74-\mathrm{km})$ reach (Steele and others, 1978).

lorns, Hembree, and Oakland (1965) estimated that the average annual dissolved-solids load of the Yampa River subbasin for the 1914-57 water years was about 1.8 times that of the Little Snake River subbasin. The average annual streamflow of the Yampa River for the same period was nearly 2.6 times that of the Little Snake River. The dissolved-solids load from the entire Yampa River basin was estimated at nearly 406,000 tons $(368,000 \mathrm{t})$ per year (lorns and others, 1965, table 13) for the 1914-57 water years. Recent calculations indicate that the average annual dissolved-solids load during the 1951-74 water years was approximately 450,000 tons $(404,000 \mathrm{t})$ annually, or perhaps 10 percent higher than the estimates of lorns, Hembree, and 0akland (1965) for the 1914-57 water years. In either instance, about 5 percent of the dissolved-solids load of the Upper Colorado River Basin is contributed by the Yampa River basin (lorns and others, 1965, fig. 8).

Seasonal patterns of specific conductance and streamflow (fig. 10) are shown for the Yampa River below diversion, near Hayden, Colo. (site Y-47, fig. 1), for August 1975 through September 1976. The pronounced increase in streamflow with a corresponding decrease in specific conductance during snowmelt runoff in spring and early summer is typical year after year and elsewhere in the basin (lorns and others, 1965, fig. 102).

Even minor specific-conductance fluctuations correlate well with changes in streamflow during snowmelt runoff (fig. 11), as is shown by detailed 


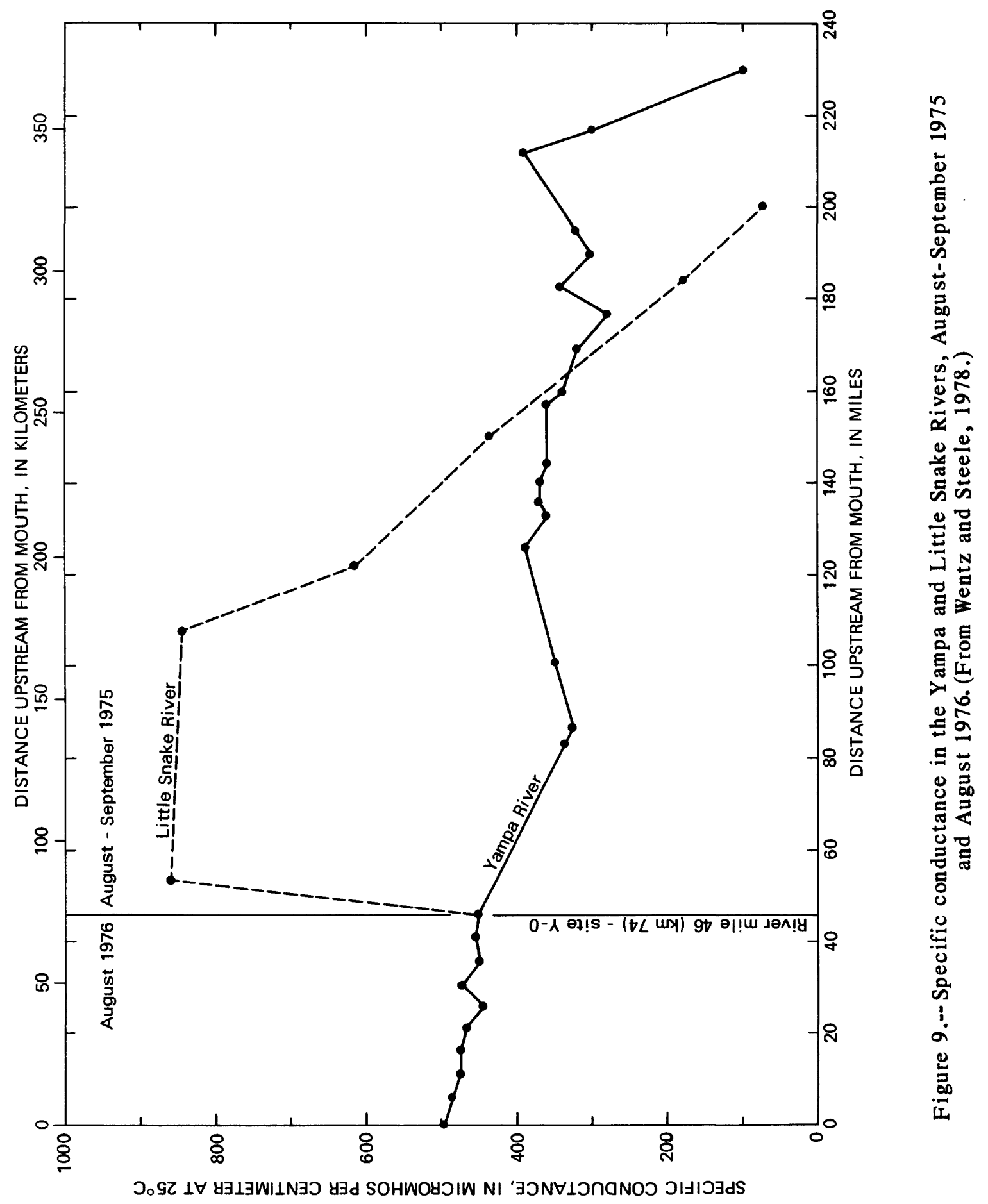




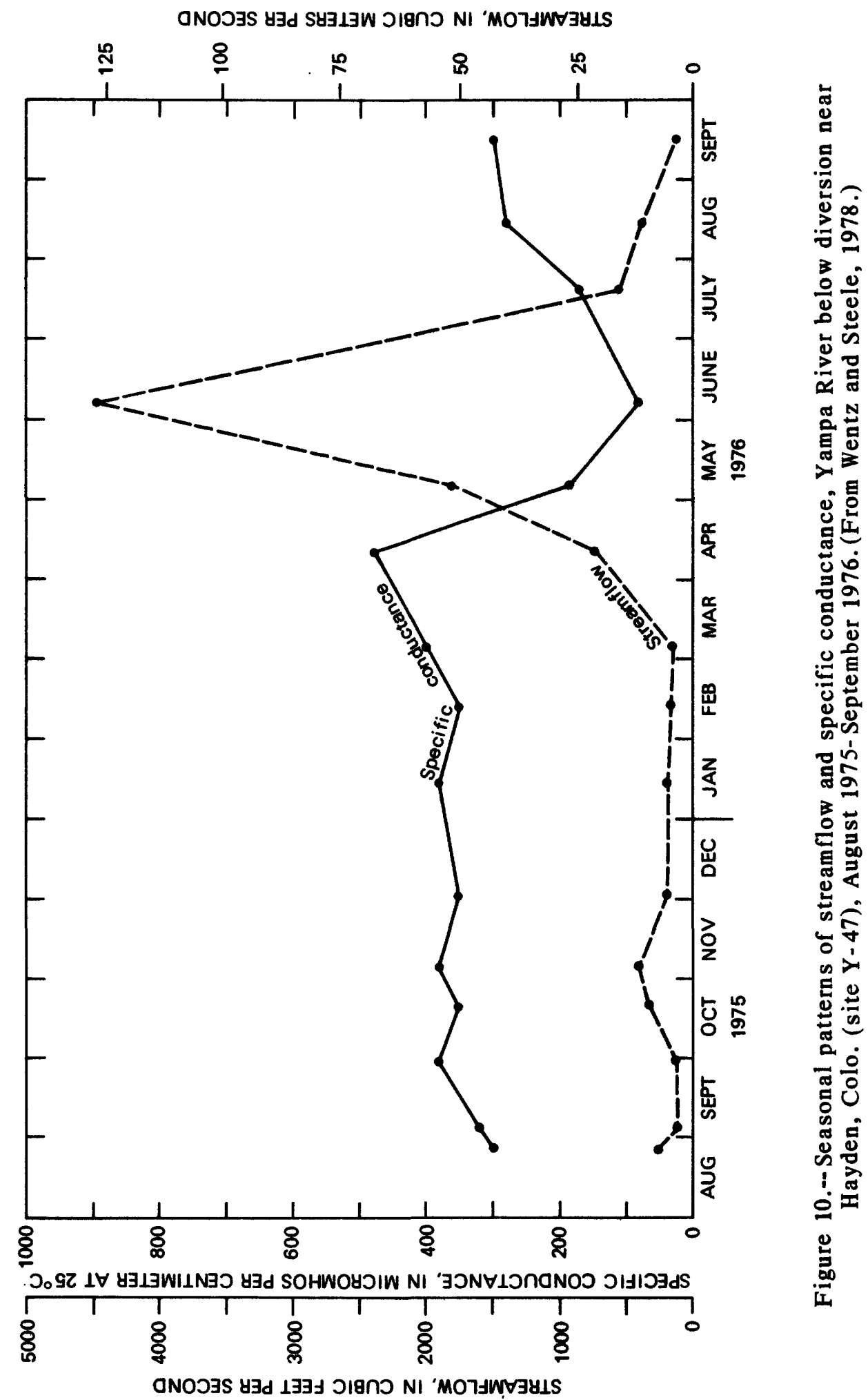




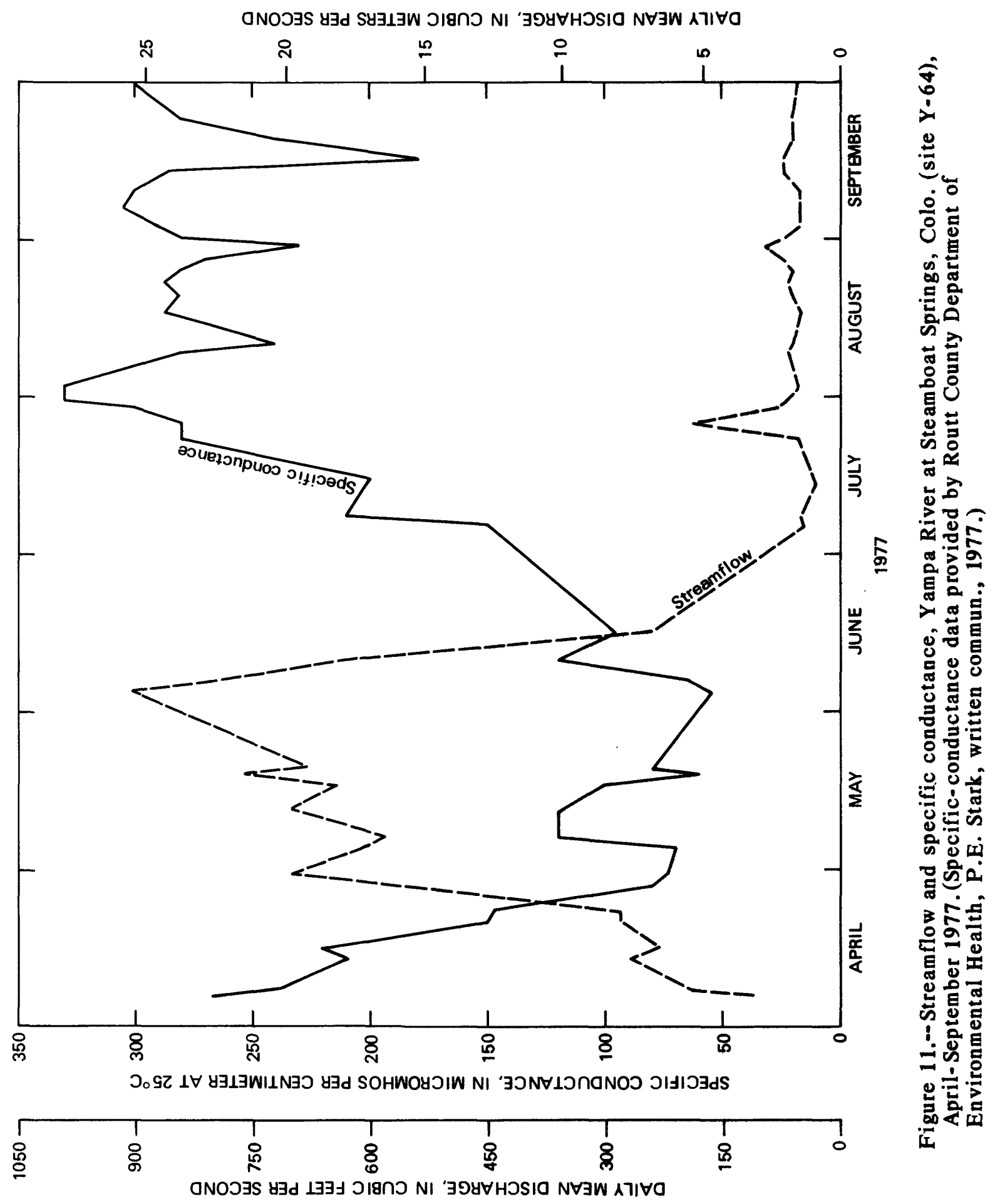


studies of the Yampa River at Steamboat Springs, Colo. (site Y-64, fig. 1) for April through September 1977. The correlation is obvious for the snowmelt-runoff period (April-June), but does not occur during the low-flow period (July-September). This is corroborated by figure 12, which shows a negative correlation at this site between specific conductance and streamflow greater than $136 \mathrm{ft}^{3} / \mathrm{s}\left(3.85 \mathrm{~m}^{3} / \mathrm{s}\right)$ :

$\log$ (specific conductance, in umhos per centimeter at $25^{\circ} \mathrm{C}$ ) $=4.01-0.74 \cdot \log$ (streamflow, in cubic feet per second).

The correlation coefficient of this equation is 0.87 , which means that 76 percent $\left(0.87^{2} \cdot 100\right)$ of the variation in specific conductance can be accounted for by changes in streamflow. At stream discharges less than $136 \mathrm{ft}^{3} / \mathrm{s}$ $\left(3.85 \mathrm{~m}^{3} / \mathrm{s}\right)$, the specific conductance can be estimated by the mean value ( 270 umhos) for the period.

Seasonal changes in specific conductance also are documented by the frequency distributions shown on figure 13. The pattern of slightly larger values in March 1976 and slightly smaller values in June 1976 than in December 1975 or August-September 1976 agrees with the data on figure 10. The larger than expected specific-conductance values in August-September 1975 probably result because eight fewer sites were sampled at that time compared to August-September 1976, and the specific conductance was less than 400 umhos at these eight sites during August-September 1976.

\section{Stream Quality During Low Flow}

\section{Trace Elements and $\mathrm{pH}$}

During the basinwide reconnaissance, water samples were collected at 82 sites for determination of dissolved (0.45-micrometer membrane-filtered) and total cadmium, cobalt, copper, iron, lead, manganese, mercury, nickel, selenium, vanadium (dissolved only), and zinc (Brown and others, 1970). Stream-bottom sediments also were sampled wherever possible. Because of the large size of some of the bed materials, however, samples were obtained at only 48 of the 82 sites. Bottom sediments having a nominal particle diameter less than 208 micrometers were extracted in hot hydrochloric acid (Malo, 1977). The sediments extracted include part of the fine sand fraction and all of the very fine sand, silt, and clay fractions. Antimony, arsenic, chromium, copper, iron, lead, mercury, and nickel were determined from the acid extract. Information on the precision of determinations of dissolved and total trace-element concentrations in water and trace-element concentrations in stream-bottom sediments is given in table 17 in the Supplemental Information section at the back of this report. Frequency distributions for all dissolved and total trace elements in water and for trace elements in stream-bottom sediments are included in the Supplemental Information section. Mean values were determined by including all sites except $Y-21, Y-26, Y-46$, $Y-54$, and $Y-68$, as discussed on the following pages. 


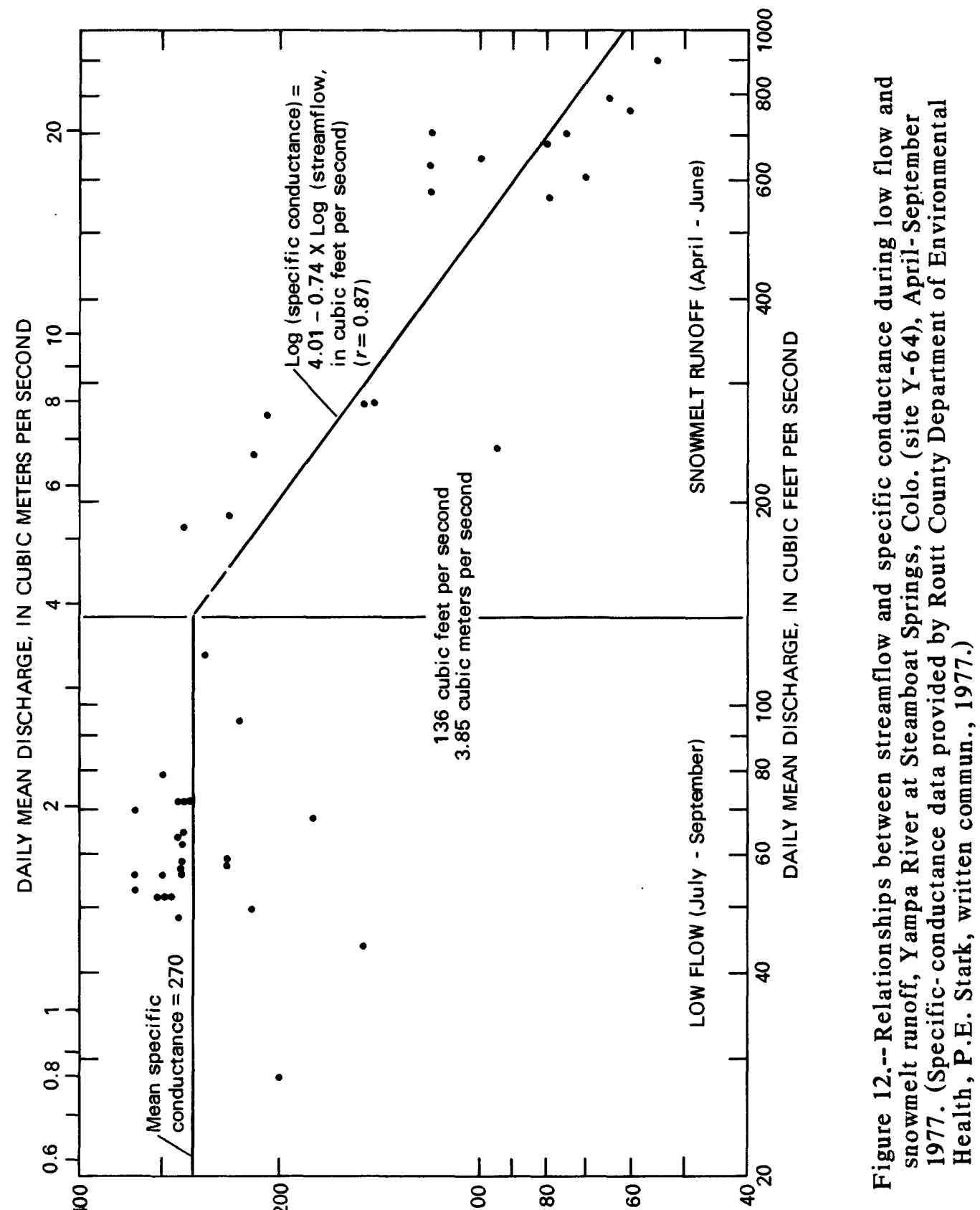

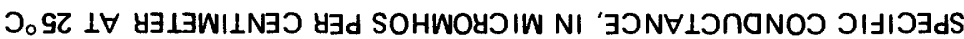



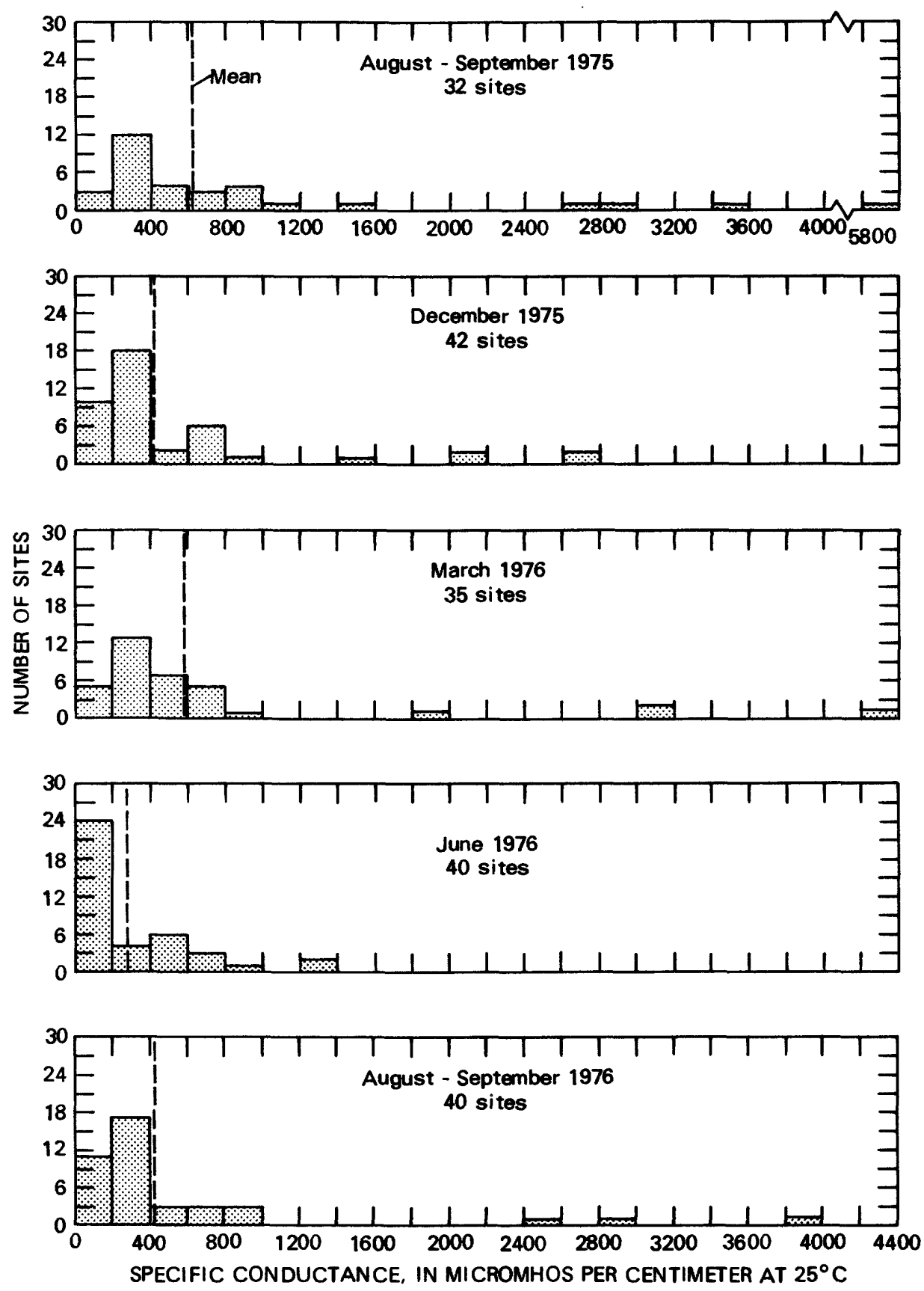

Figure 13.-- Frequency distributions of specific conductance in streams of the Yampa River basin, August-September 1975 through AugustSeptember 1976. 
Trace elements in water--general considerations.--Rickert, Kennedy, McKenzie, and Hines (1977), in their analysis of trace elements in streambottom sediments of the Willamette River basin, Oregon, used normalprobability plots to distinguish polluted from background conditions. The technique is described by Velz (1970, p. 522-542). It is based on the fact that polluted and background samples represent two different sample populations, and that the data characteristics of polluted and background conditions define two separate and distinguishable straight lines on normalprobability paper.

Unfortunately, the technique described above is not applicable to dissolved or total trace-element concentrations in streams of the Yampa River basin. The primary reason for this is the departure of these trace-element frequency distributions from normality. According to Miesch (1967, p. B3), "The most common departure of geochemical data from the normal distribution is a positive skewness." Frequency distributions of dissolved and total trace elements in streams of the Yampa River basin exemplify this condition; however, most do not conform to the log-normal distribution that Miesch (1967) states is often the underlying cause of the positive skewness. The total selenium distribution shown on figure $14 \mathrm{~A}$ exhibits the strong positive skewness that is typical of all the trace elements evaluated in this part of the study except dissolved copper (fig. 14B) and total zinc, which are more symmetrical.

Moreover, even the symmetrical frequency distributions for dissolved copper and total zinc in streams of the Yampa River basin are not necessarily normal. The distribution of total zinc, when plotted on normal-probability paper (fig. 15A), might be interpreted as representative of two normally distributed segments--one defined by the 72 points from 0 to $20 \mu \mathrm{g} / \mathrm{L}$ (micrograms per liter) and the other by the 8 points from 30 to $50 \mu \mathrm{g} / \mathrm{L}$. However, when plotted on log-normal-probability paper (fig. 15B), the same distribution might be considered representative of a single log-normally distributed segment.

Thus, a different technique was needed for analyzing frequency distrubutions of dissolved and total trace-elements from streams in the Yampa River basin. Such a technique would have to be applicable to a wide variety of distributions, the exact natures of which of ten would not be known. The technique chosen consists of two steps. First, all distributions were transformed to standard form using the formula:

$$
z_{i}=\frac{x_{i}-\bar{x}}{s}
$$

where $x_{i}=$ individual value;

$\bar{x}=$ mean value; and

$s=$ standard deviation. 

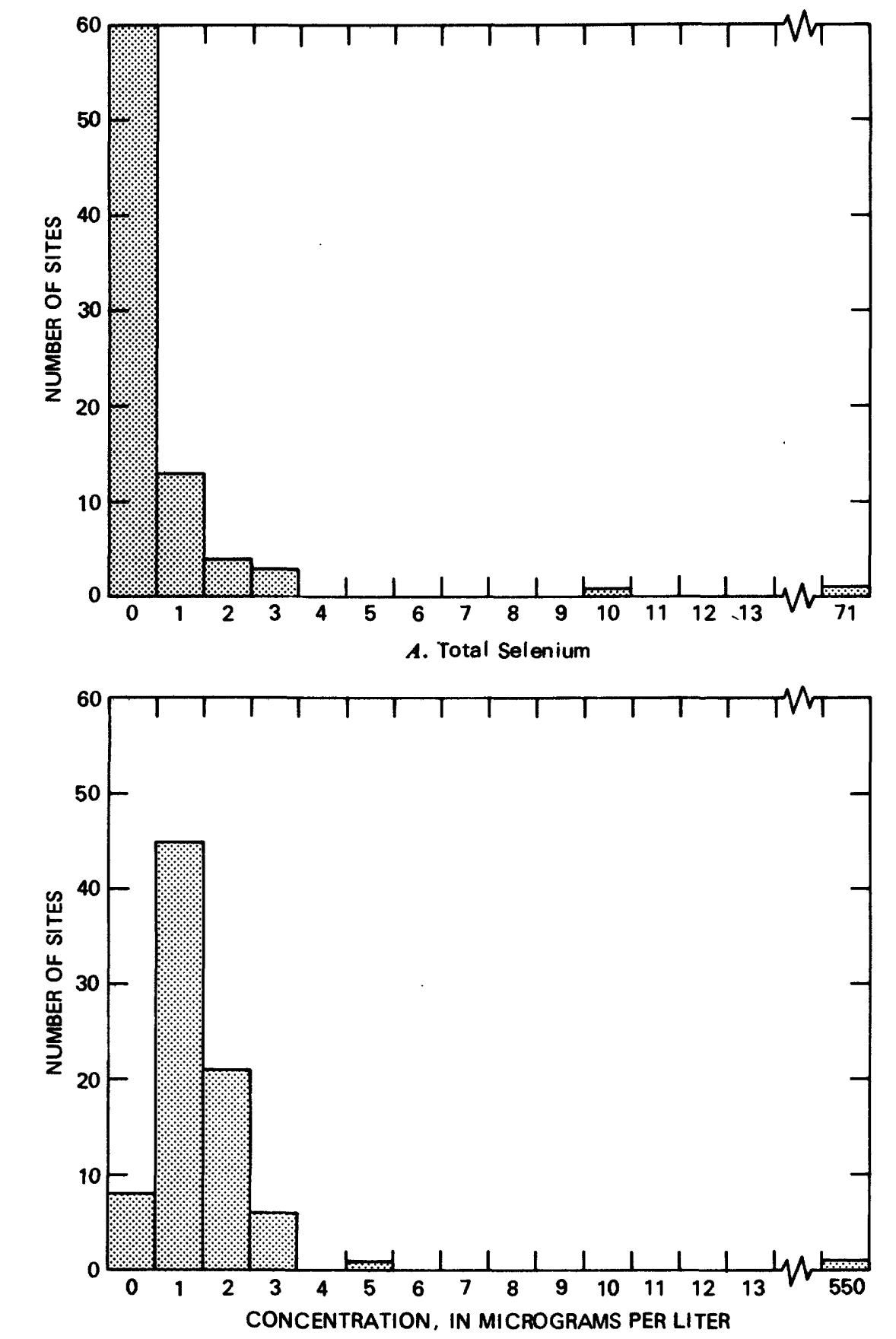

B. Dissolved Copper

Figure 14.-- Frequency distributions of total selenium and dissolved copper in streams of the Yampa River basin, August-September 1975. (From Wentz and Steele, 1978.) 

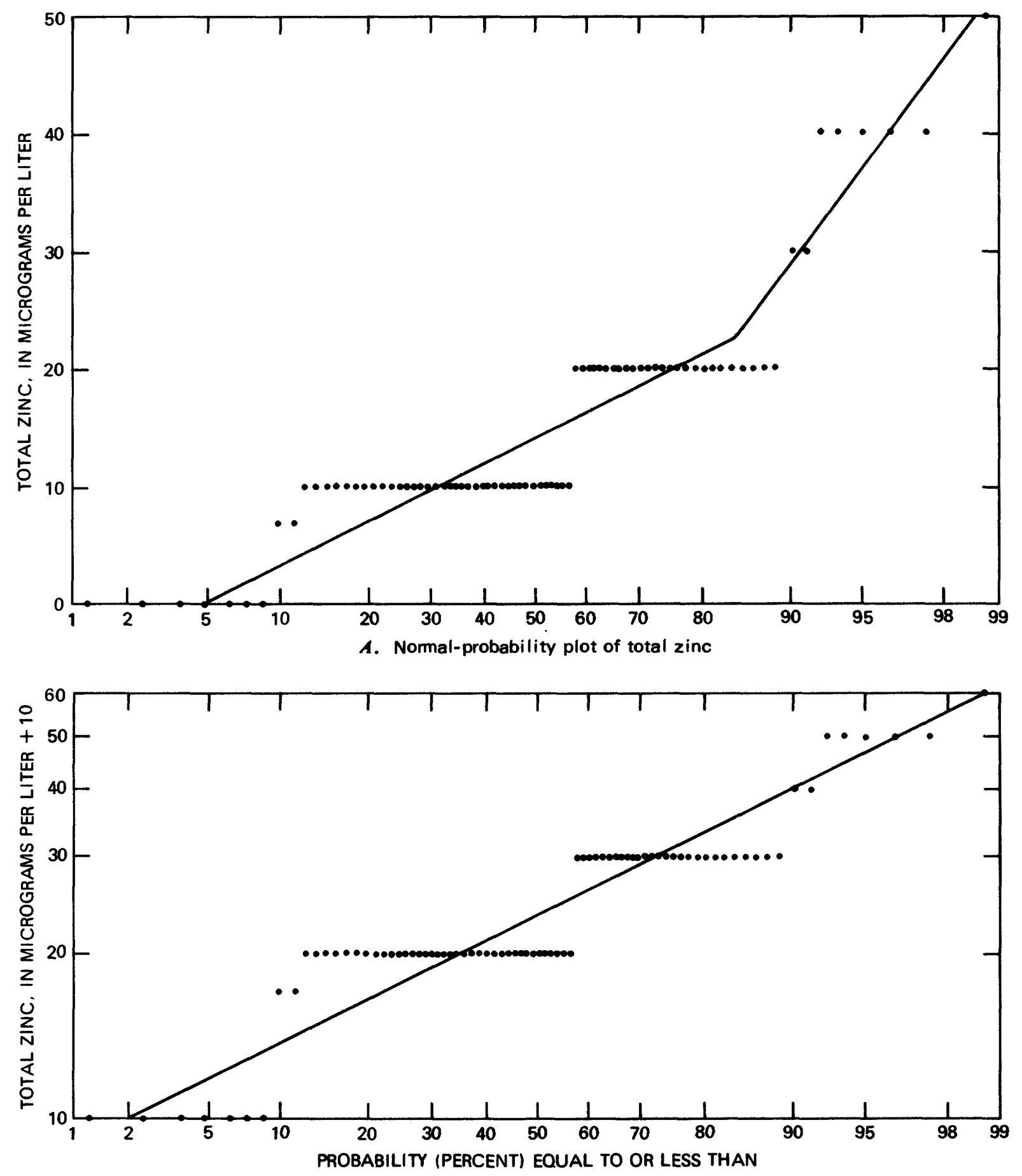

B. Log-normal-probability plot of total zinc

Figure 15.-- Probability plots of total zinc in streams of the Yampa River basin, August-September 1975. 
The transformed distributions have means of zero and standard deviations of one. The second step involved application of Tchebycheff's inequality (Rickmers and Todd, 1967, p. 405), which states that for any distribution the relative size of the area deviating from the mean by $k$ or more standard deviations is less than $1 / k^{2}$. If $k=4.47$, and if all data falling outside the limits $\bar{x} \pm 4.47 \mathrm{~s}$ are considered as outliers, then a minimum of 95 percent $\left[1-\left(1 / 4.47^{2}\right)\right] \cdot 100$ of the background distribution will be retained. That is, if a value is designated as an outlier, there is less than a 5-percent chance that the value is not truly an outlier but rather is a part of the background distribution. Because of the large deviation from the mean $(4.47 \mathrm{~s})$ required to designate a value as an outlier, the test is considered by the authors to be conservative.

It should be noted that the above approach is not mathematically rigorous. This results because the means and standard deviations actually used in equation 6 are sample values; whereas, those referred to in Ichebycheff's inequality assume population values. Because the sample values $\bar{x}$ and $s$ are random variables (their values are a function of the values of $x$. actually sampled), the standard deviations of the transformed distributions may not be exactly one. However, discrepancies are expected to be minor, as relatively large samples were used to calculate values of $\bar{x}$ and $s$. The means of the transformed distributions will be zero, in any instance.

Use of the outlier-analysis technique, as described above, is illustrated in figure 16, which shows the frequency distribution for total manganese in streams of the Yampa River basin during August-September 1975. The abscissa after transformation to standard form is indicated below the original abscissa. The transformed distribution is shown to have a mean of zero and a standard deviation of one. The upper limit of 4.47 standard deviations (equal to $1,400 \mathrm{\mu g} / \mathrm{L}$ on the original absicssa) is noted. All data outside this limit have been designated as outliers.

The various trace-element frequency distributions were analyzed using the outlier-analysis technique, and the outliers were separated from the background distributions (representative of ambient conditions). All outliers in this and subsequent sections of the report are positive; they exceed the limit $x+4.47 \mathrm{~s}$. For example, the total manganese concentrations of 1,700 and $1,800 \mathrm{\mu g} / \mathrm{L}$ (fig. 16) are considered to be outliers. In interpreting the outlier-analysis results, consideration was given to the fact that a relatively large concentration of a dissolved trace element could be interpreted as an outlier in both the dissolved and total distributions for that element. The latter could occur if suspended concentrations were of minor importance, and thus the total concentration were virtually completely dissolved.

Designation of a trace-element concentration as an outlier involves no preconceived implication as to cause. Outliers can be due to upstream sources of water-quality degradation, and they can result from improper sample-collection techniques or from analytical errors. The precision data in table 17 in the Supplemental Information section provide knowledge regarding the summation of sample-collection and analytical efficiency. These 


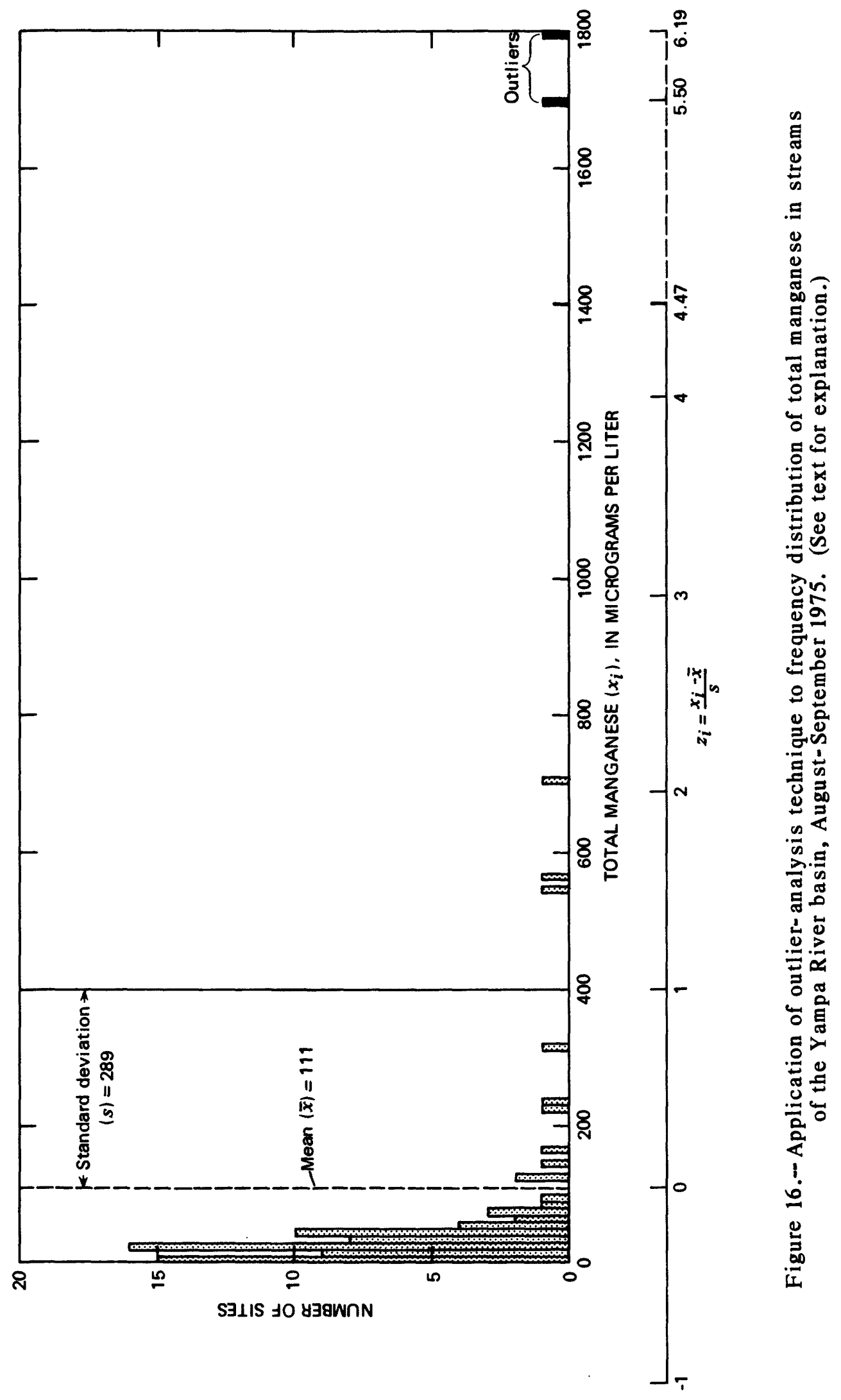


data have not been evaluated statistically; however, it can be seen that the standard deviation in most instances is quite small, particularly in relation to the mean. This fact, in conjunction with the previously discussed conservativeness of the outlier test ( $p .43$ and 46), indicates to the authors that all outliers are due to upstream sources of water-quality degradation.

Based upon the outlier analysis of dissolved and total trace-element concentrations from the basinwide reconnaissance, water at four sites indicated upstream sources of water-quality degradation (fig. 17). These sites are Y-68 (six outliers), Y-46 (three outliers), Y-26 (three outliers), and $Y-54$ (two outliers). If iron and manganese are deleted from the outlier analysis, sites $Y-68, Y-46$, and $Y-26$ remain ( 3 outliers each). Justification for deleting iron and manganese is based on the ubiquity of the number of occurrences of these trace elements not meeting water-quality standards (table 5). Dissolved and total iron and manganese account for 96 percent of the occurrences where water-supply standards are not met, 30 percent of the occurrences where aquatic-life standards are not met, and 79 percent of the occurrences where agricultural standards are not met (table 9). This would indicate that a separate technique might be used to examine the iron and manganese concentrations. Although total and dissolved mercury account for 50 percent of the occurrences where aquatic-life standards are not met, this may result from the aquatic-life standard $(0.05 \mu \mathrm{g} / \mathrm{L}$, table 5$)$ being less than the smallest mercury concentration $(0.1 \mu \mathrm{g} / \mathrm{L})$ detectable by routine analytical procedures in use by the U.S. Geological Survey. Thus, mercury was not removed from the outlier analysis.

Si te $Y-68$, known as the 0ak Creek drain, appears to be a drainage tunnel and is the only site in Colorado where Wentz (1974a) determined that water is affected by the oxidation of pyritic materials associated with coal. Water issuing from the drain deposits a bright-orange coating of ferric hydroxide (yellow boy) on the channel bottom between the tunnel and Oak Creek. Although the drain discharges into 0ak Creek immediately east of the ridge separating the Oak Creek subbasin from the Edna Mine to the west, no evidence exists to suggest the drainage originates at the surface in the vicinity of the coal strip mine. Rather, the drain appears to have provided a method of removing water from underground coal mines, now abandoned, in the vicinity so they could be worked.

In addition to dissolved manganese $(1,800 \mu \mathrm{g} / \mathrm{L})$, dissolved iron $(6,500$ $\mu \mathrm{g} / \mathrm{L})$, and total iron $(14,000 \mu \mathrm{g} / \mathrm{L})$, total cadmium $(10 \mu \mathrm{g} / \mathrm{L})$ and dissolved cobalt $(5 \mu \mathrm{g} / \mathrm{L})$ and nickel $(16 \mu \mathrm{g} / \mathrm{L})$ were present in excessive concentrations in the water at site $Y-68$ in August-September 1975. Enough dilution from 0ak Creek occurs so that the latter three constituents are not a problem at site Y-67 (fig. 1), which is $0.5 \mathrm{mi}(0.8 \mathrm{~km})$ downstream from the Oak Creek drain. However, manganese concentrations exceeded the standard for water supplies at site $\mathrm{Y}-66$, which is at the mouth of 0ak Creek. Previous chemical data for the Oak Creek drain have been reported by Wentz (1974a) and Moran and Wentz (1974). Their results indicate that copper, lead, and vanadium also may occur in excessive concentrations in the drain at certain times of the year, but that downstream effects on Oak Creek are minimal. 


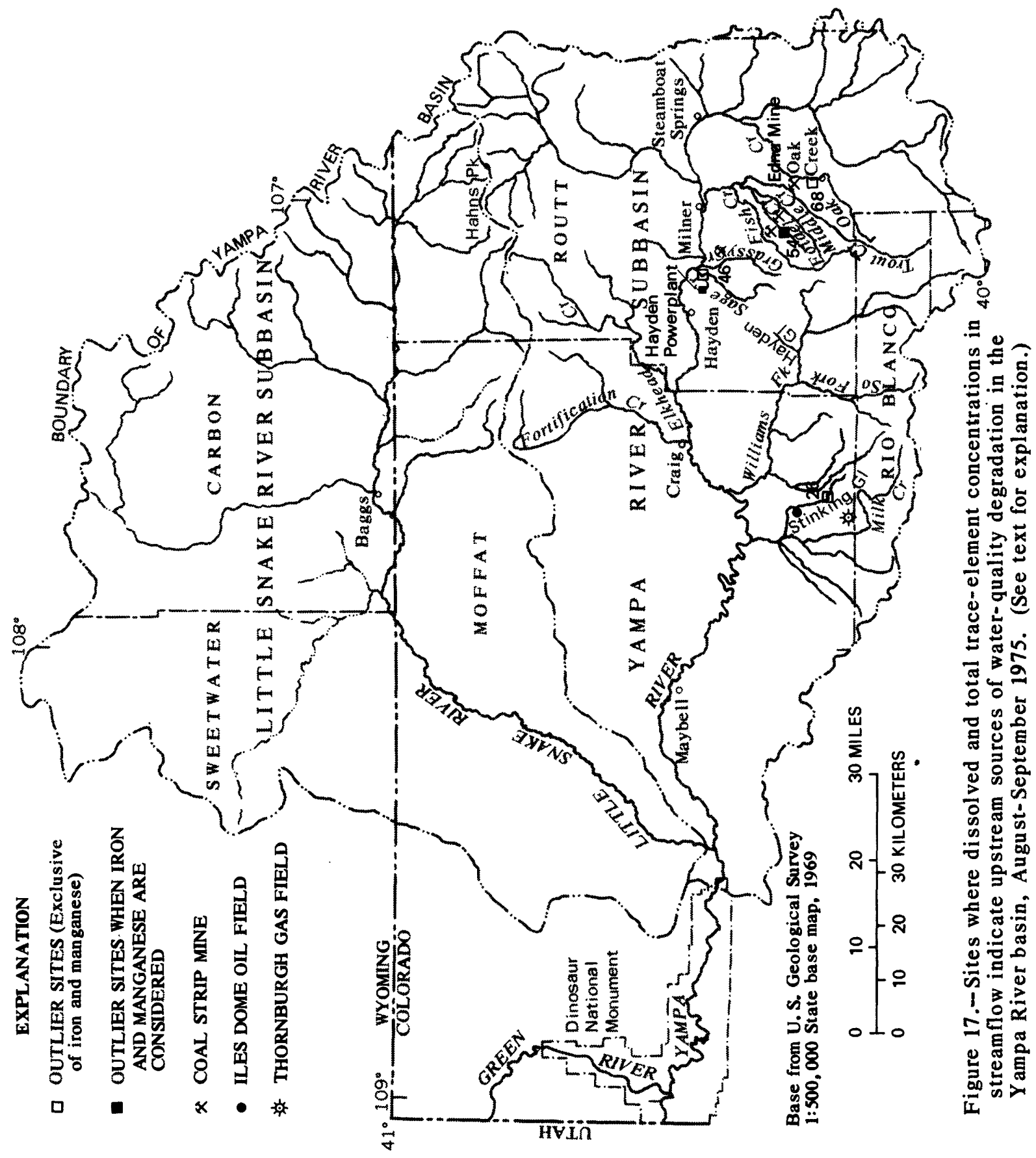


Table 9.--Number of sites where trace-element concentrations and $p H$ in streamflow did not meet water-supply, aquatic-life, and agricultural standards', Yampa River basin, August-September 1975

\begin{tabular}{|c|c|c|c|c|c|c|}
\hline \multirow{2}{*}{$\begin{array}{l}\text { Water- } \\
\text { qual ity } \\
\text { variable }\end{array}$} & \multicolumn{2}{|c|}{$\begin{array}{l}\text { Wa ter-supply } \\
\text { standards }\end{array}$} & \multicolumn{2}{|c|}{$\begin{array}{c}\text { Aquatic-life } \\
\text { standards }\end{array}$} & \multicolumn{2}{|c|}{$\begin{array}{l}\text { Agricultural } \\
\text { standards }\end{array}$} \\
\hline & Dissolved & Total & Dissolved & Total & Dissolved & Total \\
\hline Cadm i um----- & 0 & 0 & 0 & ${ }^{2} 2$ & 0 & 0 \\
\hline Copper-- & 0 & 0 & 1 & 3 & 1 & 1 \\
\hline Iron-n- & 3 & 33 & 2 & 13 & -- & -- \\
\hline Lead-----n- & 0 & 31 & 1 & 31 & 0 & 0 \\
\hline Manganese--- & 12 & 23 & 0 & 0 & 7 & 8 \\
\hline Mercury------ & 0 & 0 & 7 & 18 & 0 & 0 \\
\hline Nickel-n. & -- & -- & 0 & 0 & 0 & 0 \\
\hline $\mathrm{pH}--\cdots-\cdots-\cdots--$ & 3 & -- & 3 & -- & -- & -- \\
\hline Selenium-- - & 1 & 1 & 1 & 1 & 1 & 1 \\
\hline Zinc- & 0 & 0 & ${ }^{4} 0$ & ${ }^{4} 0$ & 0 & 0 \\
\hline
\end{tabular}

${ }^{1}$ See table 5 for a summary of water-use standards. Because of uncertainties as to which trace-element form (dissolved or total) should be compared to the water-use standards, both forms have been included.

${ }^{2}$ The minimum limit of detection for total cadmium is $10 \mu \mathrm{g} / \mathrm{L}$ (micrograms per 1 iter), and 80 values were reported as less than $10 \mu \mathrm{g} / \mathrm{L}$. Two values of $10 \mu \mathrm{g} / \mathrm{L}$ were determined; these are the only values that definitely exceeded the aquatic-life standard of $0.4 \mu \mathrm{g} / \mathrm{L}$.

${ }^{3}$ The minimum limit of detection for total lead is $100 \mu \mathrm{g} / \mathrm{L}$, and 80 values were reported as less than $100 \mu \mathrm{g} / \mathrm{L}$. One value of $100 \mu \mathrm{g} / \mathrm{L}$ was determined; this is the only value that definitely exceeded the water-supply standard of $50 \mu \mathrm{g} / \mathrm{L}$ and the aquatic-life standard of $4 \mu \mathrm{g} / \mathrm{L}$.

${ }^{4} 1 \mathrm{t}$ is suspected that water at site $\mathrm{Y}-46$ had total and dissolved $\mathrm{zinc}$ concentrations that exceeded the $50 \mu \mathrm{g} / \mathrm{L}$ limit for aquatic life; however, analytical problems prevented confirmation.

Site $Y-46$ is on Sage Creek downstream from the coal-fired Hayden Powerplant. When this site was visited at noon on September 4, 1975, the pH of the stream was 2.1. This was less than any pH reported by Wentz (1974a) or Moran and Wentz (1974) for water draining from mines in Colorado. In addition, the water at site $\mathrm{Y}-46$ contained excessive concentrations of dissolved copper $(550 \mu \mathrm{g} / \mathrm{L})$, lead $(14 \mu \mathrm{g} / \mathrm{L})$, and vanadium $(7.9 \mu \mathrm{g} / \mathrm{L})$.

The excessive trace-element concentrations, particularly copper and lead, are probably not the direct result of coal burning. These elements would be expected to be concentrated in the fly ash (Klein and others, 1975). Since December 1974, fly ash from the Hayden Powerplant has been returned to the strip mine in the Grassy Creek drainage (upstream from site Y-48, fig. 1) and covered with spoil (Leon Brestel, oral commun., December 1977). 
A more plausible explanation is that the increased trace-element concentrations at site $Y-46$ originate in the blowdown water from the cooling towers. According to Stearns-Roger Corp. (1971, p. 6), an average of 510 $\mathrm{gal} / \mathrm{min}(32 \mathrm{~L} / \mathrm{s})$ of liquid effluent, consisting primarily of cooling-tower blowdown and deionizer regeneration wastewater, was contributed to Sage Creek by the Hayden Powerplant. Stratton and Lee (1975) noted increased concentrations of ammonia, nitrate, phosphorus, sulfate, copper, chromium, iron, lead, mercury, and zinc in water from 11 cooling towers; cadmium, manganese, and nickel were not demonstrated to be problems. According to Stratton and Lee (1975), excessive concentrations of chemical constituents in blowdown water can result from several processes, including a natural concentration of from two to eight times due to evaporative cooling; corrosion of pipes; and addition of chemicals to inhibit scaling, corrosion, and algal growth. For the Hayden Powerplant, the concentration factor resulting from evaporation cooling is estimated to range from 3.7 to 3.9. Details of the calculation are given on p. 161 of the Supplemental Information section.

The $\mathrm{pH}$ of 2.1 at site $\mathrm{Y}-46$ on September 4, 1975, may have resulted from sulfuric acid added to lessen scaling problems in the cooling towers. This also is indicated by the increase in sulfate concentration from $130 \mathrm{mg} / \mathrm{L}$ at site $Y-46 \mathrm{~A}$ (fig. 1) upstream from the Hayden Powerplant to $1,700 \mathrm{mg} / \mathrm{L}$ at site $Y-46$ downstream from the powerplant. Theoretical calculations indicate that the concentration of sulfate in the powerplant effluent would have to be 60 times that in the intake water in order to affect Sage Creek to this extent. If no sulfate were added in the powerplant, this would imply a concentration factor that is considerably greater than the range of 3.7 to 3.9 times expected for conservative constituents. Assuming that all sulfate is added as sulfuric acid, the predicted $\mathrm{pH}$ at site $\mathrm{Y}-46$ would be 1.5 . If some sulfate were added as other salts or some acid were titrated via buffering reactions, the measured $\mathrm{pH}$ of 2.1 and the above postulated mechanism seem reasonable.

If the observed degradation of water quality in Sage Creek does result from blowdown water from the Hayden Powerplant cooling towers, this apparently is not a continuous process, at least not to the degree indicated above. Site $\mathrm{Y}-46$ was visited again during a 24-hour study of the waste-load assimilative capacity (Bauer and others, 1978) on September 23-24, 1975. Specific-conductance values ranged from 430 to 1,650 umhos (compared to 6,000 umhos on September 4), and $\mathrm{pH}^{\prime}$ s ranged from 6.8 to 7.4 . Thus, it is probably somewhat fortuitous that water quality at this site was determined to be seriously degraded on the basis of the measurements and water analyses made as part of the August-September 1975 reconnaissance.

Because of dilution effects, potential detrimental impacts of discharges from the Hayden Powerplant are considerably lessened when water from Sage creek is mixed with the much greater flow of the Yampa River. Chemical determinations at the Yampa River below Sage Creek (site Y-45, $10 \mathrm{mi}$ or $16 \mathrm{~km}$ downstream from Sage Creek, fig. 1) did not indicate any discernible adverse effects on water quality at the time of the reconnaissance. 
Although water-quality problems at sites $Y-68$ and $Y-46$ were not totally unexpected, those at site $\mathrm{Y}-26$ near the headwaters of Stinking Gulch were not anticipated. This site was originally chosen as an upstream control for site Y-25 (fig. 1), which is downstream from the lles Dome oil field. The only potential source of contamination known to be in the watershed upstream from site $\mathrm{Y}-26$ is the Thornburgh gas field, which contains several gas wells.

The water at site $\mathrm{Y}-26$ contained total cadmium $(10 \mu \mathrm{g} / \mathrm{L})$ and lead $(100 \mu \mathrm{g} / \mathrm{L})$ and dissolved selenium $(67 \mu \mathrm{g} / \mathrm{L})$ in concentrations greater than background levels. Although the stream drains primarily the Upper Cretaceous Mancos Shale, other streams draining this formation (for example, sites $Y-28$, $Y-35, \quad Y-37, \quad Y-52, Y-70$, and $Y-75$, fig. 1) do not have similar water-quality problems. Concentrations of iron exceeded the water-supply standard downstream to site $\mathrm{Y}-21$ on Milk Creek; whereas, manganese concentrations exceeded the water-supply standard downstream only to site $\mathrm{Y}-25$. Concentrations of iron and manganese also exceeded the water-supply standard near the headwaters of Milk Creek (site $\mathrm{Y}-28$, fig. 1), which drain an adjacent watershed. Whether the relatively high trace-element concentrations are natural or due to development of the Thornburgh gas field is not known.

Iron, manganese, and mercury--special problems.--Iron, manganese, and mercury (table 9) appear to pose problems in several streams of the Yampa River basin. The sites where iron and manganese in streamflow did not meet water-supply standards are located on figures 18 and 19 . With respect to these two elements, eight general problem areas have been identified. Seven of the areas are similar. Of these seven, the three represented by sites $Y-68, Y-46$, and $Y-26$ al ready have been discussed.

The four remaining areas where both iron and manganese in streamflow exceeded water-supply standards are (1) the streams draining Hahns Peak (including some or all of sites $Y-13, Y-14, Y-60, Y-61$, and $Y-62)$; (2) the Fish, Foidel, and Middle Creek drainages (sites $Y-51, Y-53, Y-54$, and $Y-55$ ); (3) the Grassy Creek drainage (sites $Y-48$ and $Y-49$ ); and (4) the South Fork Williams Fork drainage $($ site $\mathrm{Y}-32)$. These areas are outlined on figures 18 and 19.

Hahns Peak is an area of known sulfide mineralization (Vanderwilt, 1947, p. 186-189). Gold, silver, copper, lead, and zinc have been mined there in the past, but no current metal mining is known to be occurring. It is possible that large concentrations of iron and manganese occur naturally in waters draining this area.

Surface coal mining was occurring in the Fish, Foidel, and Middle Creek drainages and the Grassy Creek drainage at the time of the basinwide reconnaissance. In the former area, iron and manganese occurred at concentrations exceeding water-supply standards in streamflow at sites $Y-51, Y-53$, and $Y-55$ downstream from and at site $Y-54$ upstream from the stripping operations. Although Foidel Creek at site $Y-54$ had a slightly larger total-iron concentration than at the downstream site (site $Y-53$ ), total- and dissolvedmanganese concentrations in the water were an order of magnitude larger 


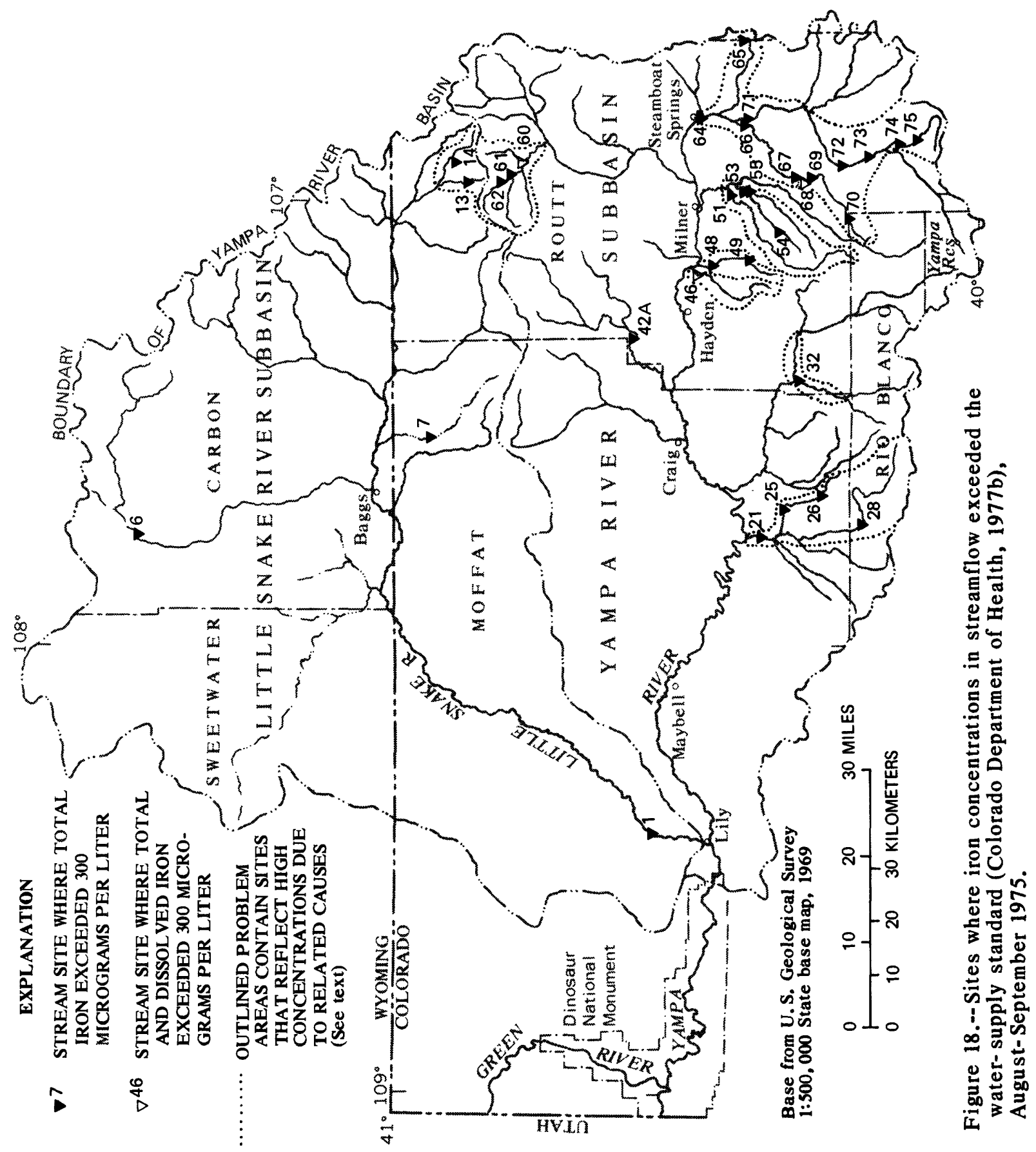




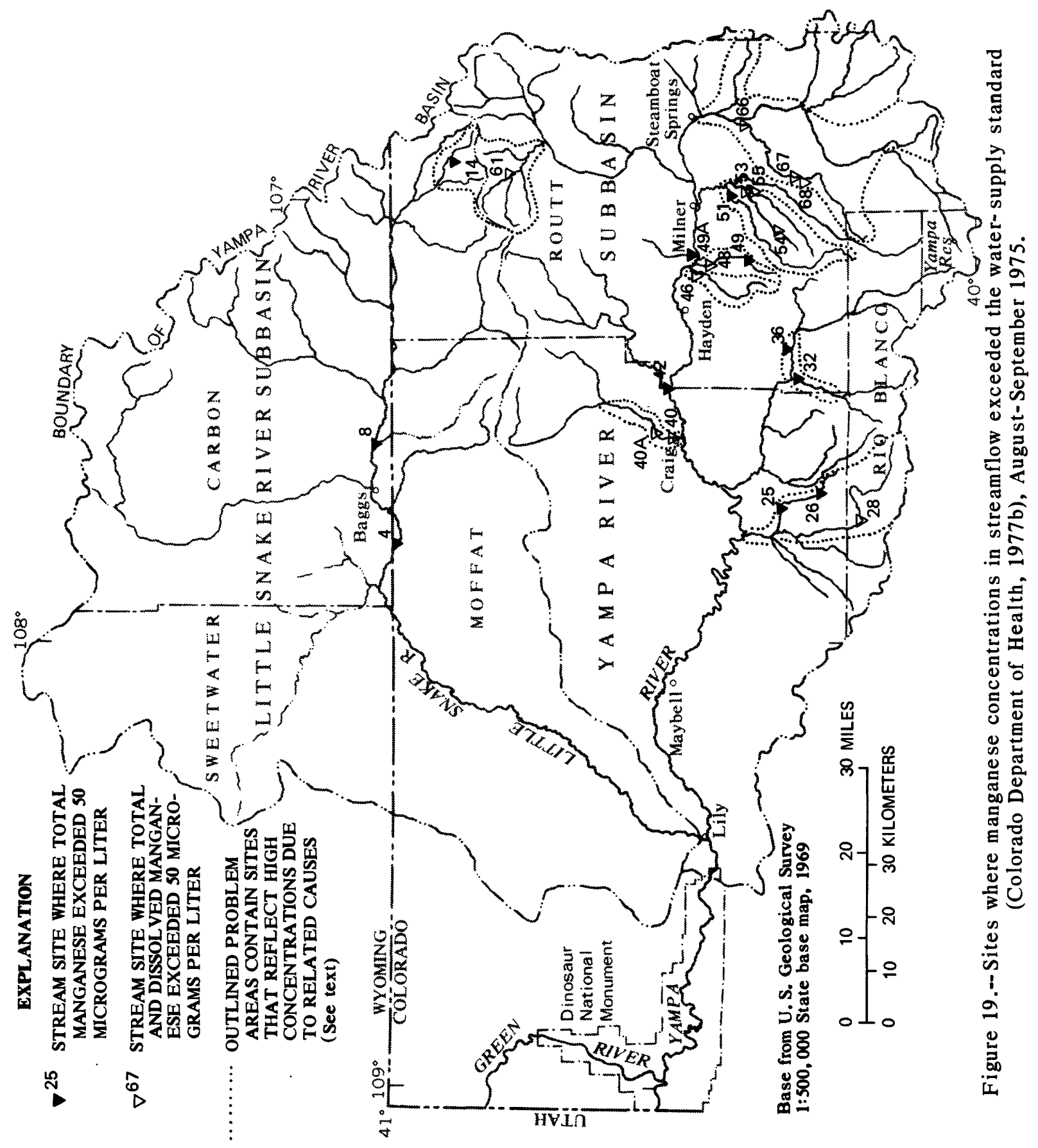


at site $\mathrm{Y}-54$. In this regard, it should be noted that there was no continuous surface flow in Foidel Creek at the time of the August-September 1975 reconnaissance, and this may have been partly responsible for the large iron and manganese concentrations determined in the water at sites $Y-53$ and $Y-54$. However, based on measurements obtained at the sites, particularly water temperatures, it is inferred that water was flowing in the channel alluvium; thus, water in the surface pools that were sampled apparently was being renewed.

In the Grassy Creek drainage, water at site $Y-49$ upstream from and water at site $\mathrm{Y}-48$ downstream from the surface coal-mining operation had iron and manganese concentrations greater than water-supply standards. However, water at the downstream site contained larger concentrations of total iron and total and dissolved manganese than water at the upstream site. Ratios of concentrations (sites $\mathrm{Y}-48$ to $\mathrm{Y}-49$ ) were as follows: Total iron (2.3), total manganese $(8.1)$, and dissolved manganese (8.8).

Water at site $\mathrm{Y}-32$, on the South Fork Williams Fork, contained totaliron and total-manganese concentrations that exceeded water-supply standards. Although coal was not being mined in the area upstream from this site at the time of the basinwide reconnaissance, such mining is known to have occurred there in the past. The same is true for Hayden Gulch upstream from site $Y-36$ (just northeast of site $Y-32$ ), where the water contained total-manganese concentrations greater than the water-supply standard.

Another area, reflecting only iron concentrations in excess of the water-supply standard, includes the upper reaches of 0ak Creek (sites $Y-69$ and $\mathrm{Y}-70$, fig. 18) and the Yampa River (sites $Y-71, Y-72, Y-73, Y-74$, and $Y-75$, fig. 18). The problem was augmented on 0ak Creek by the Oak Creek drain, and the effect persisted downstream at least to Steamboat Springs (site $Y-64$ ) during August-September 1975. The cause of these relatively large iron concentrations is not known.

In contrast, another area drained by Fortification Creek (sites $\mathrm{Y}-40$ and Y-40A, fig. 19) contained only concentrations of manganese greater than the water-supply standard in August-September 1975. The source of the manganese in Fortification Creek appears to be in the drainage basin upstream from Craig, but the nature of this source is not known. A comparable totalmanganese concentration at site $\mathrm{Y}-42$ on Elkhead Creek to the east also may be related to this source.

Longitudinal stream-reach profiles of total- and dissolved-iron concentrations in the Yampa and the Little Snake Rivers during the basinwide reconnaissance are shown on figure 20. In the Yampa River, dissolved-iron concentrations were relatively constant at $70 \mu \mathrm{g} / \mathrm{L}$ or less. However, total-iron concentrations were as much as $760 \mu \mathrm{g} / \mathrm{L}$ in the upper reaches of the Yampa River (as discussed above), decreased to 50 to $140 \mu \mathrm{g} / \mathrm{L}$ in the middle reaches (probably a result of dilution), and began to increase again to $250 \mu \mathrm{g} / \mathrm{L}$ at the most downstream site $($ site $Y-0)$. Much of the latter increase results from the inflow of the Little Snake River, which contains excessive totaliron concentrations at the mouth (fig. 20B). 


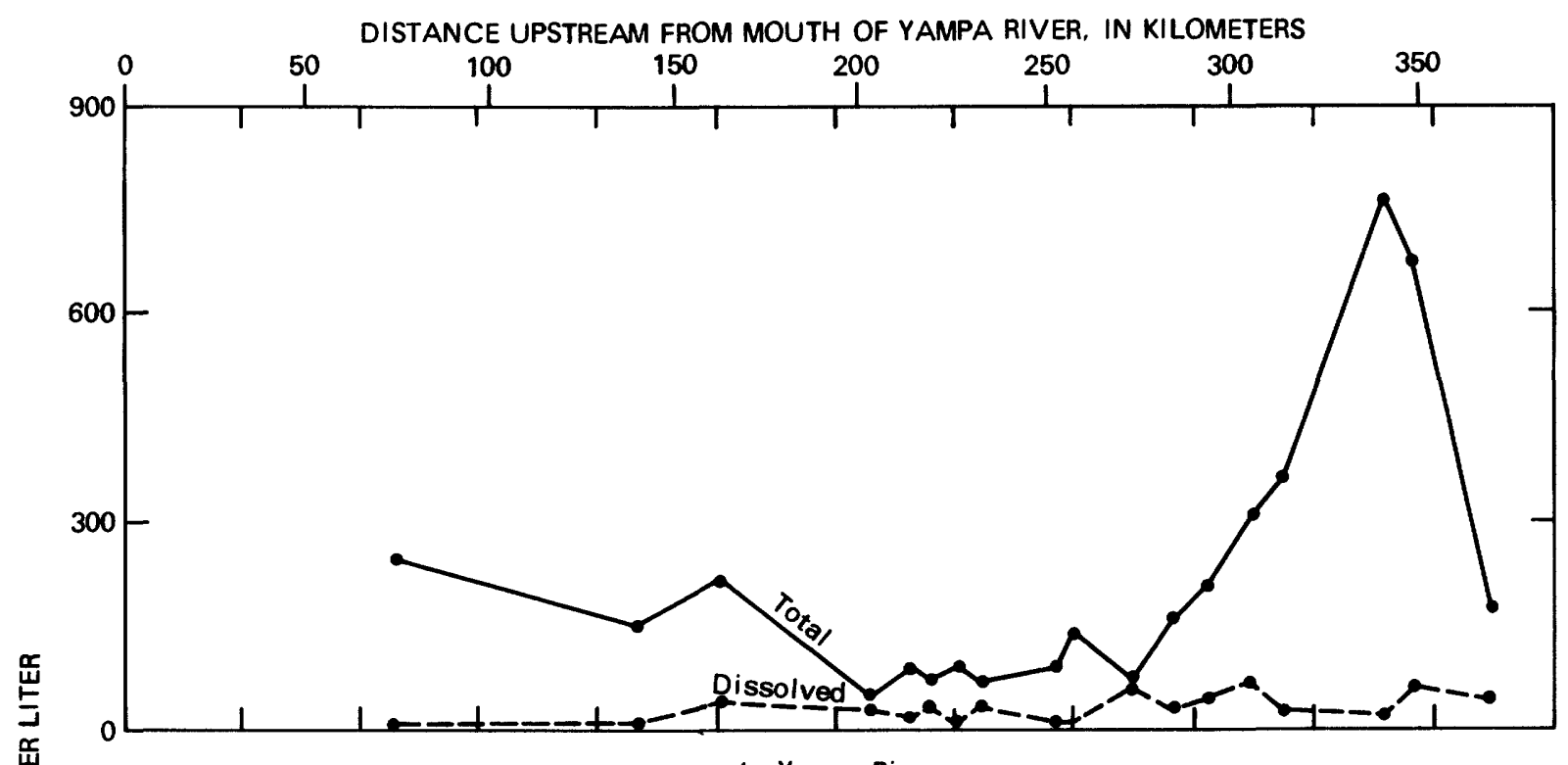

A. Yampa River

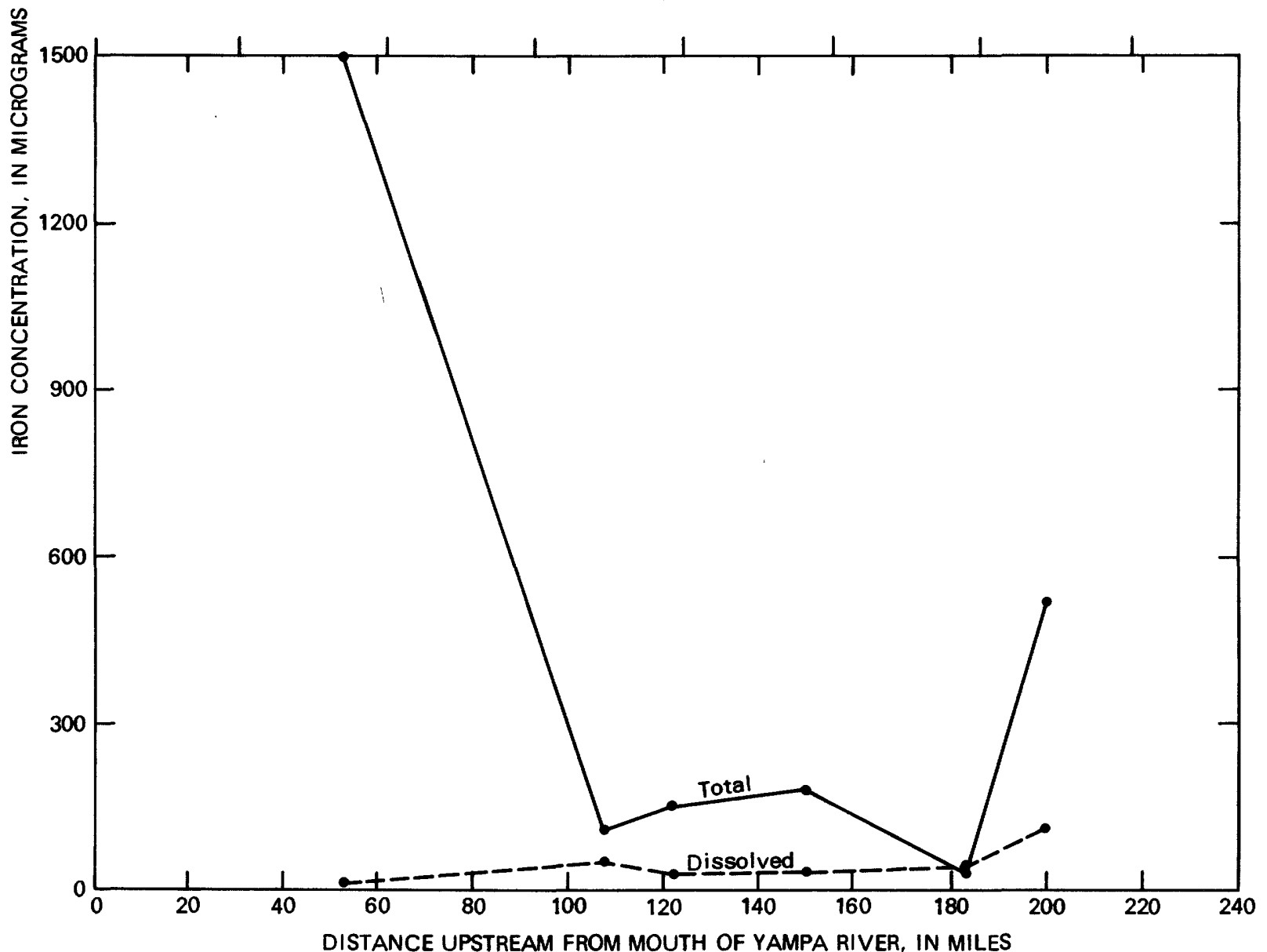

DISTANCE UPSTREAM FROM MOUTH OF YAMPA RIVER, IN MILES

B. Little Snake River

Figure 20.--Stream-reach profiles of total- and dissolved-iron concentrations, August - September 1975. 
Both dissolved- and total-iron concentrations are relatively large $(110 \mu \mathrm{g} / \mathrm{L}$ for dissolved iron, $520 \mu \mathrm{g} / \mathrm{L}$ for total iron, fig. 20B) near the headwaters of the Little Snake River, probably as a result of sulfide mineralization in the Hahns Peak area. Downstream, dissolved-iron concentrations decreased to values comparable to those in the Yampa River; whereas, totaliron concentrations increased to $1,500 \mu \mathrm{g} / \mathrm{L}$. This concentration of total iron, most of which is in the suspended phase, is apparently caused by the iron content in easily eroded sediments of the lower Little Snake River subbasin.

Profiles for dissolved and total manganese in the Yampa River (not shown in this report) indicate that concentrations of both forms decrease slightly downstream, with all values less than or equal to $50 \mu \mathrm{g} / \mathrm{L}$. Profiles for the Little Snake River (also not shown in this report) indicate values of 0 to 10 $\mu \mathrm{g} / \mathrm{L}$ in the headwaters, values of total manganese as much as $80 \mu \mathrm{g} / \mathrm{L}$ in the middle reaches, and values of 0 to $50 \mu \mathrm{g} / \mathrm{L}$ in the downstream reaches. The cause of the maximum concentrations in the middle reaches is unknown.

Three streams or groups of streams where mercury exceeded the aquaticlife standard during the basinwide reconnaissance of August-September 1975 (fig. 21) warrant mentioning. First, mercury concentrations greater than the standard were noted in the upper reaches of 0ak Creek (site $\mathrm{Y}-70$ ), and the effect continued at site $Y-67$ on Oak Creek, downstream from the Oak Creek drain. Second, the headwaters of both Foidel (site Y-54) and Fish (site $Y$-52) Creeks contained mercury concentrations greater than the aquatic-life standard. On Foidel Creek, mercury concentrations at the mouth (site $Y-53$ ) were greater than the aquatic-life standard (see discussion of flows in Foidel Creek, P. 55), but this was not the case for Fish Creek. Finally, site $Y-46$, on Sage Creek below the Hayden Powerplant, also showed mercury concentrations greater than the aquatic-life standard.

Apparently, the combined sources from Foidel and Fish Creeks and from Sage Creek contribute to mercury concentrations in the Yampa River greater than the aquatic-life standard. This condition is present at site $\mathrm{Y}-50$ and continues downstream at least to Craig (site $Y-41 A$ ), and possibly to site Y-29 downstream from the confluence with the Williams Fork (fig. 21).

pH.--Small values of $\mathrm{pH}$ that indicate acidic water often are associated with excessive trace-element concentrations (Moran, 1974; Moran and Wentz, 1974; Wentz, 1974b), because many trace elements are more soluble in acid waters. Of the values of $\mathrm{pH}$ measured during the August-September 1975 reconnaissance, only the $\mathrm{pH}$ of 2.1 at site $\mathrm{Y}-46$ could be considered abnormal; it was the only value that was less than the minimum limit of 5.0 established for water supply or the minimum limit of 6.5 established for aquatic life (table 5). All other values were equal to or greater than 7.2 .

Two pH values were greater than the maximum limit of 9.0 for water supply and aquatic life (table 5). These values were measured at sites $Y-12$ $(\mathrm{pH}=9.8)$ and $\mathrm{Y}-52 \mathrm{~A} \quad(\mathrm{pH}=9.4)$. As $\mathrm{pH}$ is affected by diel fluctuations (fig. 22), it is possible that the $\mathrm{pH}$ distribution could have been substantially different, depending upon the time of day the measurements were made. 


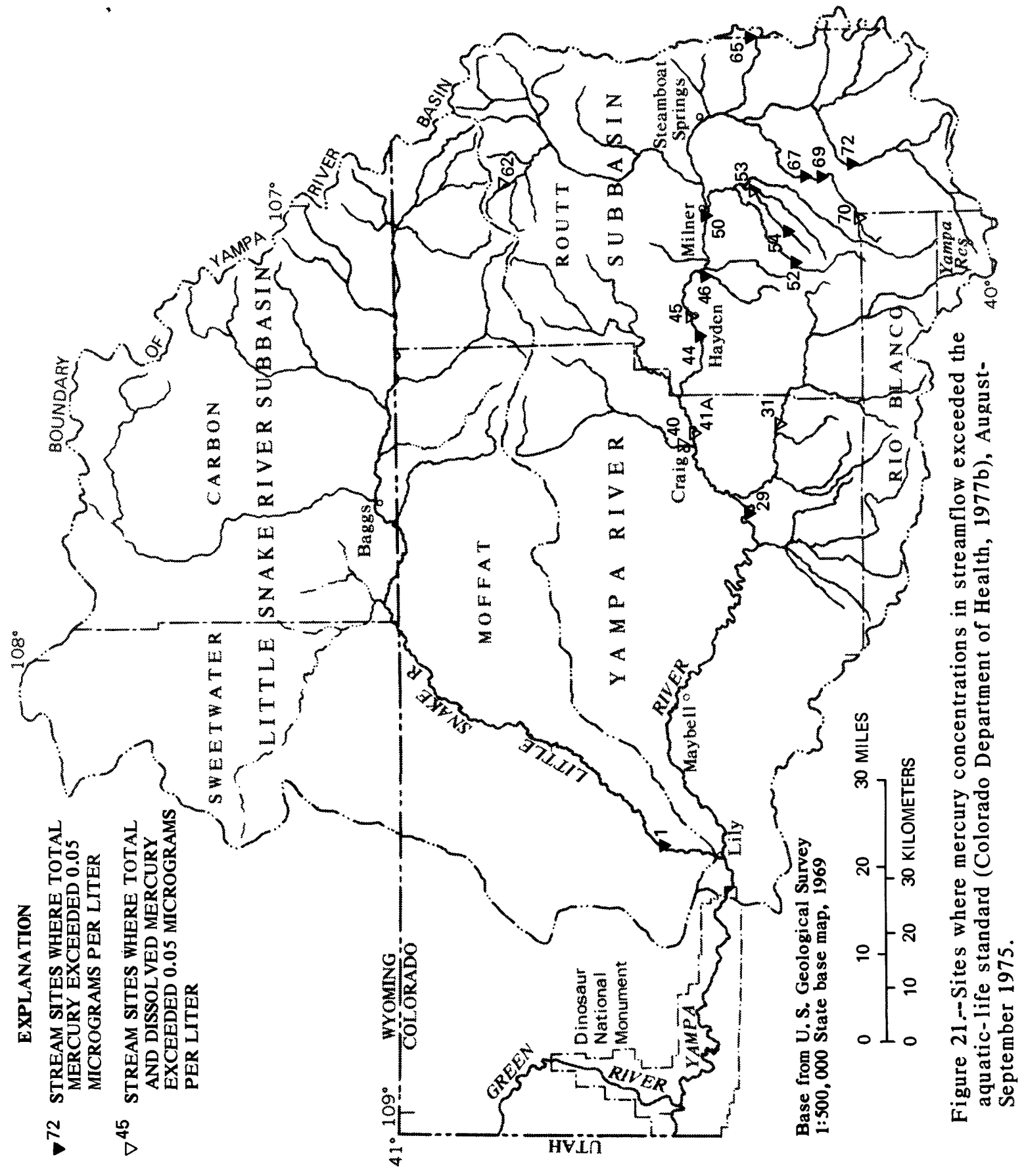




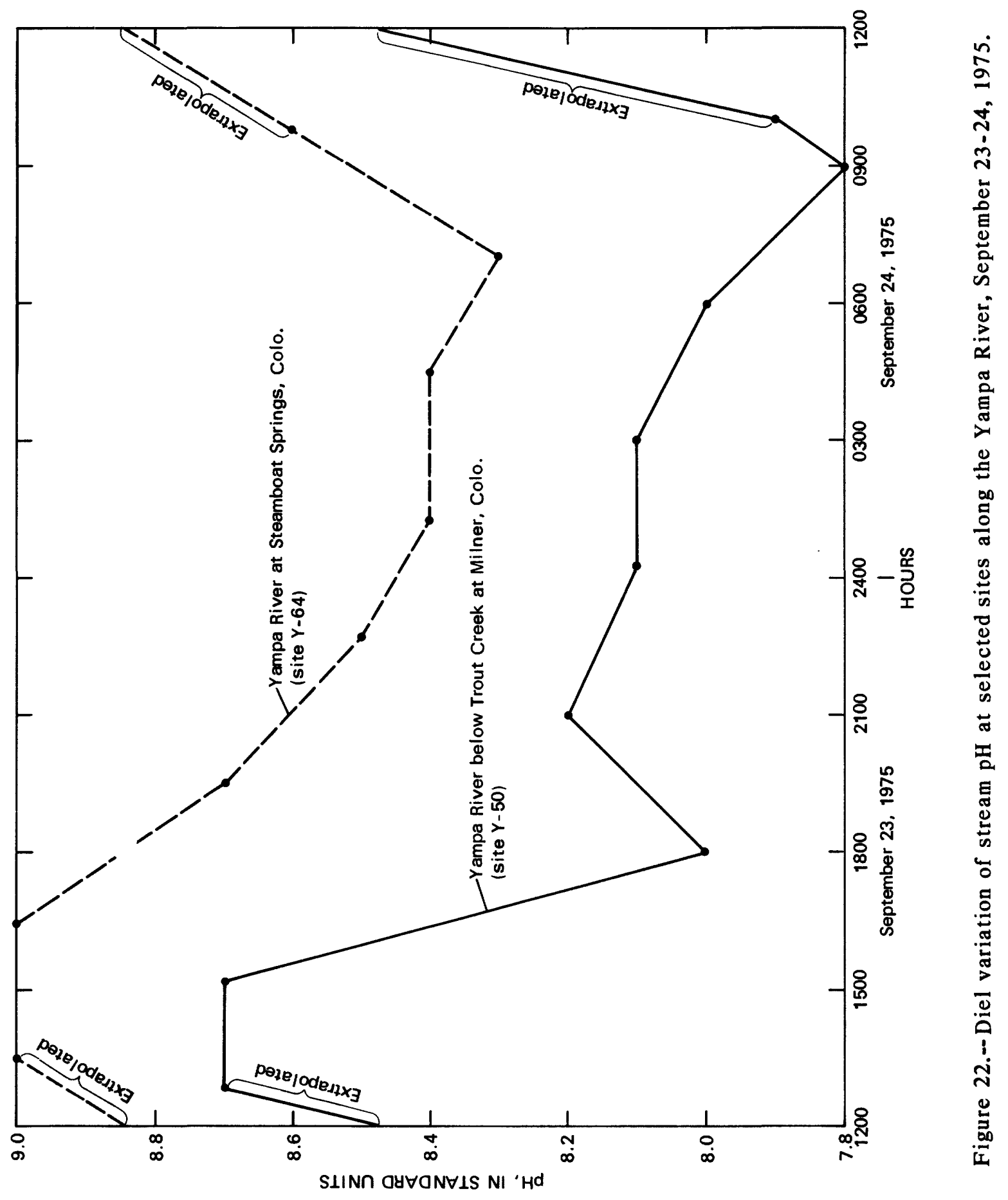


Trace elements in stream-bottom sediments.--An analysis of the trace elements associated with stream-bottom sediments provides information not obtainable from evaluating concentrations of trace elements in water collected from the same site. This is because the stream sediments are exposed to varying conditions over an extended period of time. As such, the sediments act as integrators; trace-element concentrations in these sediments represent some average of conditions during the period of exposure. Under certain circumstances, they may represent extreme conditions. The underlying assumptions in this analysis are: (1) That the trace element in question exists in the particulate phase; and (2) that bottom-sediment transport rates are substantially less than average stream velocities.

How concentrations of trace elements in stream-bottom sediments can be used to indicate a source of pollution is illustrated by the following example. Suppose that a chemical company is discharging, at irregular intervals, an acidic, metal-laden waste into an otherwise unpolluted river. The stream-bottom sediments downstream from the point of discharge adsorb some metals; whereas, other metals are precipitated and deposited on the stream bottom because of the increased $\mathrm{pH}$ resulting from dilution of the waste. Of ten these processes are relatively irreversible. That is, when the industrial discharge is halted, the adsorbed or precipitated metals are not released back into solution from the sediment, or they are released much more slowly than the rate at which they were deposited. Analysis of a water sample collected when the waste was not being discharged would reveal no problem upstream; however, analysis of a bottom-sediment sample would indicate that an industrial waste had been discharged into the river.

Bottom-sediment samples were collected wherever possible during low flow in the Yampa River basin in August-September 1975, when the movement of stream-bottom sediments was relatively unaffected by discharge. It is difficult to determine exactly what amounts of trace elements associated with the stream-bottom sediments were recovered during the analytical procedure used in this study (Malo, 1977); however, adsorbed elements, chemically precipitated elements, and organically bound elements probably were recovered. Those elements that were present as part of the internal structure of the inorganic fraction probably were not recovered.

Generally speaking, the bottom-sediment trace-element frequency distributions are approximately symmetrical, as shown by the iron distribution (fig. 23A). On the other hand, the chromium distribution (fig. 23B) is definitely positively skewed.

In contrast to the consistently normally distributed concentrations of trace elements in bottom sediments of the Willamette River basin (Rickert and others, 1977), those in the Yampa River basin are quite variable when plotted on normal and log-normal probability paper. For example, antimony, arsenic, mercury, and nickel appear to be normally distributed; copper, iron, and lead appear to be log-normally distributed; and chromium seems to be represented by neither of these distributions. The reason for this variation appears to be the more complex geology of the Yampa River basin. Because of the 


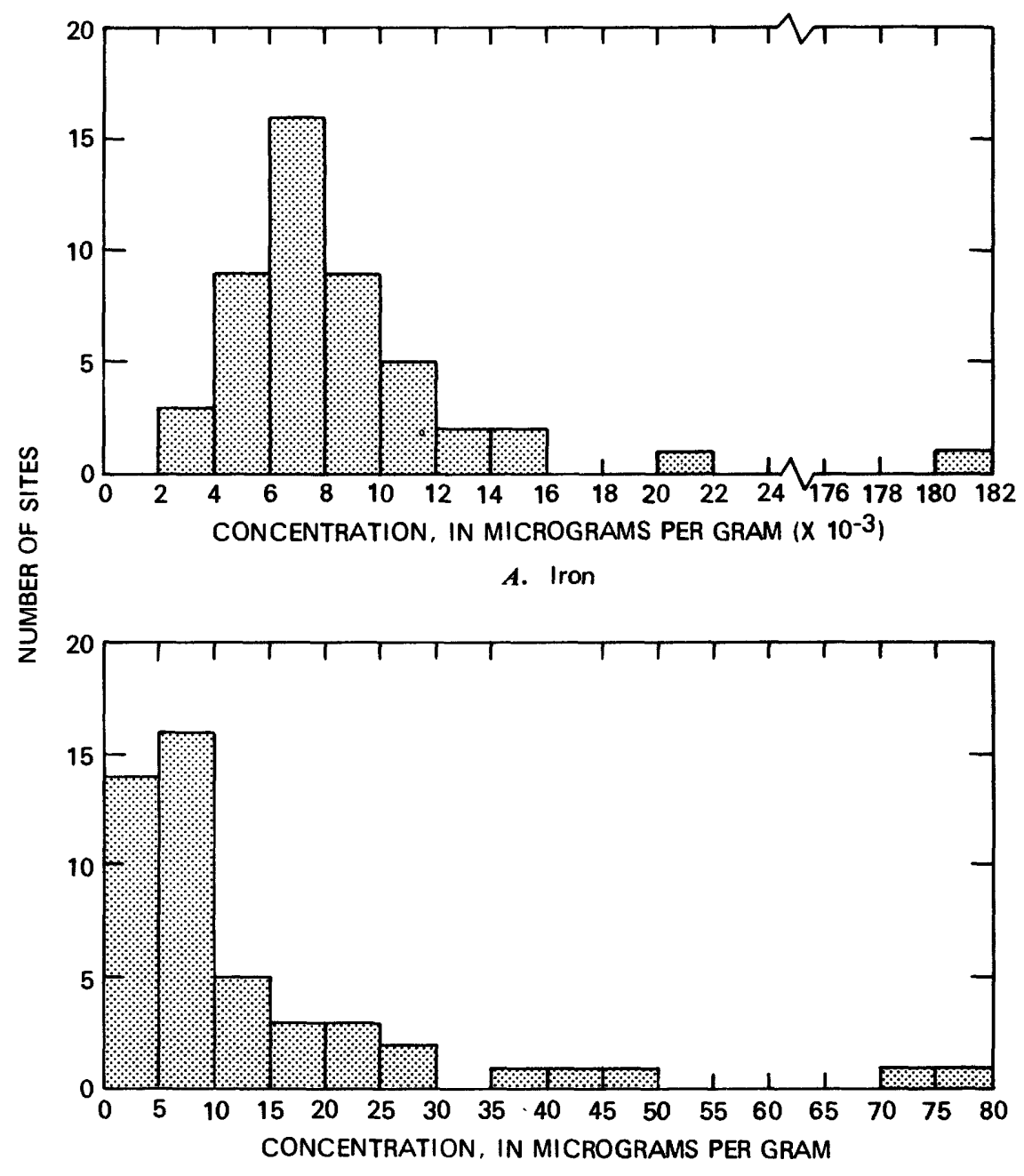

B. Chromium

Figure 23.-- Frequency distributions of iron and chromium in stream-bottom sediments of the Yampa River basin, August-September 1975. (From Wentz and Steele, 1978.) 
variability in distribution type, and to maintain consistency, the traceelement frequency distributions in stream-bottom sediments were analyzed using the same outlier technique as used for trace-element distributions in water. Based on the analysis, water-quality degradation was occurring upstream from site $\mathrm{Y}-46$ (one outlier) and site $\mathrm{Y}-68$ (three outliers). Waterquality degradation upstream from these two sites also was indicated by the water-quality sampling procedures (fig. 17).

At site $Y-68$, the arsenic concentration $(65 \mu \mathrm{g} / \mathrm{g}$, micrograms per gram) in the stream-bottom sediments was excessive. Wentz (1974a) reported the only known previous analysis of arsenic in water from this site--1 $\mu \mathrm{g} / \mathrm{L}$ on June 9, 1972. It may be that arsenic concentrations in the water are excessive only at certain times of the year, or perhaps they are generally small because of the relative insolubility of arsenic. The excessive concentrations of iron $(180,000 \mu \mathrm{g} / \mathrm{g})$ and nickel $(45 \mu \mathrm{g} / \mathrm{g})$ in the stream-bottom sediments at site $Y-68$ are not surprising, based on the trace-element concentrations in the water sample collected during the basinwide reconnaissance (p. 50). Moreover, the stream-bottom sediments at site $Y-67$ (fig. 1), which is immediately downstream from site $Y-68$, contained the second largest iron concentration $(21,000 \mu \mathrm{g} / \mathrm{g})$ determined during the basinwide reconnaissance.

The excessive copper concentration $(260 \mu \mathrm{g} / \mathrm{g})$ found in the stream-bottom sediments at site $\mathrm{Y}-46$ was not unexpected, as the water sample collected at this site during August-September 1975 also contained excessive dissolved copper (p. 48). However, the water sample gave little indication that mercury was a problem. Although not an outlier, the largest mercury concentration $(0.10 \mu \mathrm{g} / \mathrm{g})$ in stream-bottom sediments of the Yampa River basin was found at this site. Stream-bottom sediments at site $\mathrm{Y}-44$ (on the Yampa River downstream from Sage Creek, fig. 1) had the second largest mercury concentration $(0.09 \mu \mathrm{g} / \mathrm{g})$ collected during the basinwide reconnaissance, while mercury in the stream-bottom sediments at site $Y-46 \mathrm{~A}$ (the upstream Sage Creek control, fig. 1) was the same as the median concentration $(0.04 \mu \mathrm{g} / \mathrm{g})$ for this element. It should be noted that a stream-bottom sediment sample was not collected at site $Y-45$ (fig. 1), the first site on the Yampa River downstream from Sage Creek.

Site $\mathrm{Y}-26$ (fig. 17) on Stinking Gulch is somewhat unusual in that bot tom sediments at the site contained an unexpectedly large concentration of antimony $(11 \mu \mathrm{g} / \mathrm{g})$. This value is not an outlier, but it is the largest antimony concentration detected in stream-bottom sediments of the Yampa River basin during the basinwide reconnaissance. It is interesting to note that bottom sediments at site $\mathrm{Y}-28$ on Milk Creek (fig. 1), in an adjacent drainage, had the next largest concentration of antimony $(7 \mu \mathrm{g} / \mathrm{g})$. Water at site Y -26 also contained excessive concentrations of trace elements (see $p .52$ ).

A possible water-quality problem indicated only by analysis of bottom sediments was noted in the vicinity of sites $\mathrm{Y}-38$ and $\mathrm{Y}-39$ ( $\mathrm{fig} .1$ ) on the Yampa River downstream from Craig. Although neither is considered an 
outlier, bottom sediments at these two sites contained the two largest concentrations of chromium (the largest values in fig. 23B) measured during the basinwide reconnaissance. Site $\mathrm{Y}-38 \mathrm{~B}$ ( $\mathrm{fig} .1$ ) is located between sites $\mathrm{Y}-38$ and $\mathrm{Y}-39$; and although the chromium concentration in the bottom sediments $(41 \mathrm{\mu g} / \mathrm{g}$; see $\mathrm{fig} .23 B)$ is not quite as large as at sites $Y-38$ and $Y-39$, it is still larger than at most sites. Because the chromium concentrations in the bottom sediments at sites $Y-40$ and $Y-41 \mathrm{~A}$ upstream from Craig (fig. 1) are equal to or less than the median value of 5 to $10 \mu \mathrm{g} / \mathrm{g}$, the source of chromium probably is in the vicinity of Craig.

Trace-element relationships.--Because of the similarity of conclusions regarding locations of upstream sources of water-quality degradation as determined by both trace-element concentrations in water and those contained in stream-bottom sediments, the potential relationships between these two phases were investigated. Regression techniques were used on two different data sets. One data set included analyses from all sites; the second data set included only analyses from those sites where ambient conditions were indicated, that is, analyses believed not to be affected by upstream waterquality degradation. For purposes of this analysis, the second data set included analyses from all sites except $Y-21, Y-26, Y-46, Y-54$, and $Y-68$ (fig. 1). Sites $Y-26, Y-46, Y-54$, and $Y-68$ have been discussed previously (p. 48 and 62, and fig. 17). Site $Y-21$ was eliminated because sodium and chloride concentrations at this site were outliers.

Relationships between the suspended-sediment and bottom-sediment phases of the same trace element might be expected intuitively. These were investigated using simple linear regressions, such that suspended trace-element concentrations in water were the dependent variables and corresponding bottom-sediment trace-element concentrations were the independent variables. Regression analyses were made for copper, iron, lead, mercury, and nickel. Suspended iron seems to be the only trace element whose variation can be explained, at least partly, by variations in the bottom phase. The amount of suspended-iron variation accounted for is 42 percent at all sites and 35 percent at sites where ambient conditions exist. The regression equations are represented by the solid lines on figures $24 \mathrm{~A}$ and $24 \mathrm{~B}$. Examination of these graphs indicates that iron concentrations at sites $Y-67$ and $Y-68$ (fig. 1) may be somewhat anomalous in comparison to the other sites. This might have been anticipated because of the pyrite oxidation suspected of affecting water quality at these sites (p. 48). Elimination of sites Y-67 and $Y-68$ and recomputation of the regression relationships yields equations represented by the dashed lines in figures $24 \mathrm{~A}$ and $24 \mathrm{~B}$. The new regression relationships allow 30 percent of the variation at all sites and 40 percent of the variation at sites where ambient conditions exist to be explained, and do not affect the previous interpretation. The general. lack of correlation between suspended- and bottom-sediment phases of the other trace elements is readily explained because samples were collected during low flow. Under these conditions, little channel erosion should occur, and the bottom sediments should not be a significant source of suspended material. 


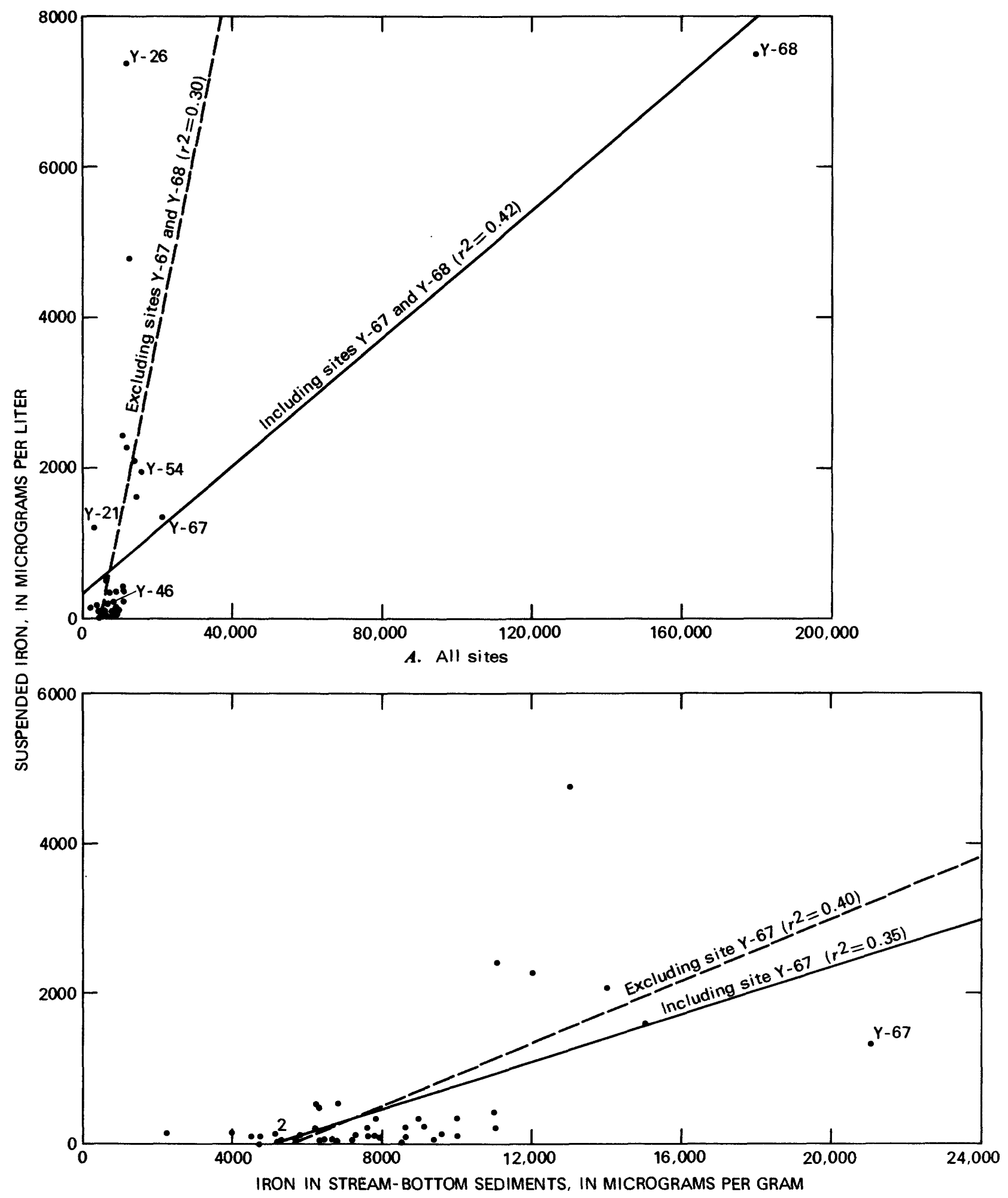

$B$. Sites where ambient conditions exist

Figure 24.-- Relationships between iron in suspended and stream-bottom sediments of the Yampa River basin, August-September 1975. 
Additional results are presented in table 10 . These relationships between trace elements in stream sediments and in water were derived from the one-to-one correlation-coefficient matrix generated as part of the regression analysis. The large decreases in percentage of variation explained from "all sites" to "sites where ambient conditions exist" are due primarily to exclusion of two sites from the relationship between bottom iron and dissolved iron and to exclusion of one site from the relationship between suspended selenium and dissolved selenium. The results indicate that the relationships determined using all sites may be artificial due to large ranges in variation resulting primarily from the addition of only one or two data values not included with the sites where ambient conditions exist. The results also point out the need for using caution when interpreting the results of correlation analyses.

Table 10.--Possible relationships between trace elements in stream sediments and in water, Yampa River basin, August-September 1975

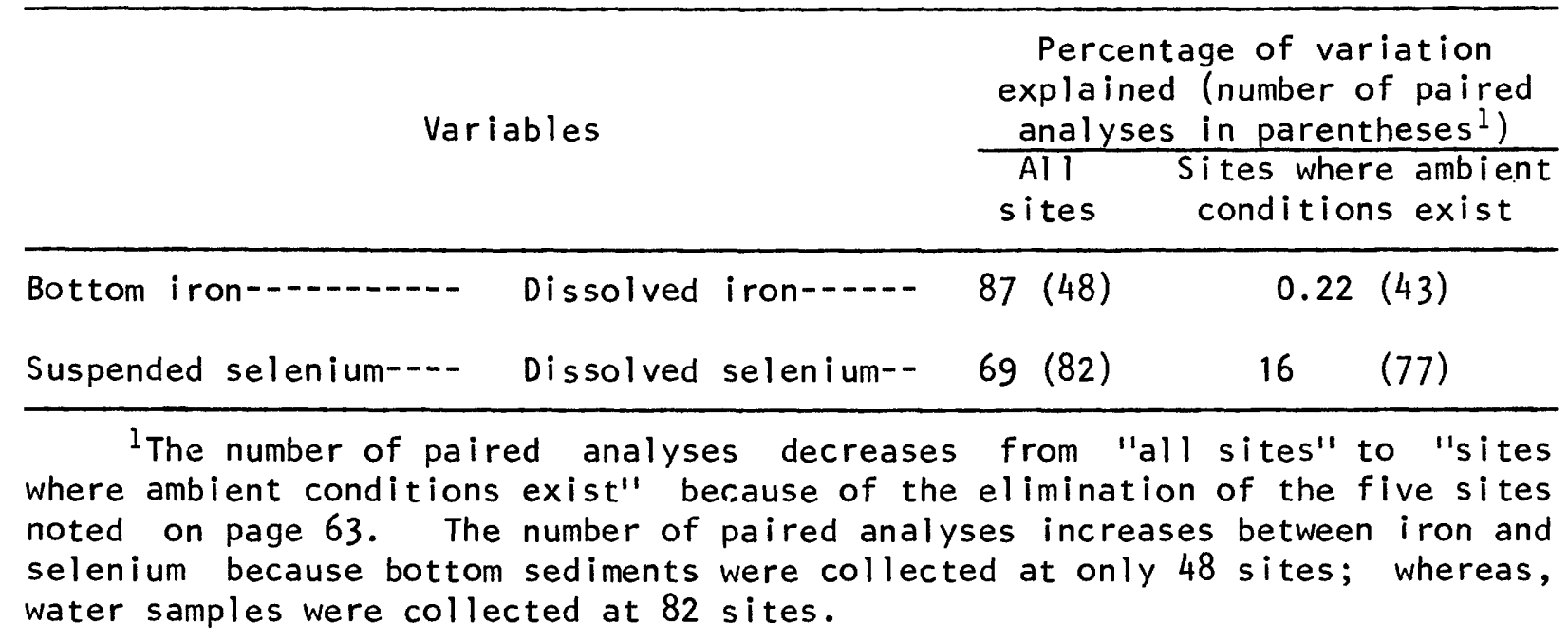


Information obtained from the one-to-one correlation-coefficient matrix for all sites also includes an apparent association of the dissolved phases of cobalt, iron, manganese, and nickel and a similar grouping of the bottomsediment phases of arsenic, iron, and nickel. Correlation coefficients for all combinations of any two of the above dissolved trace elements are greater than 0.67 , indicating that more than 45 percent of the variations can be explained. The association of dissolved trace elements does not exist if only sites where ambient conditions exist are examined; all correlation coefficients are less than 0.28 (less than 8-percent variation explained). Evidence for the association of the bottom-sediment phases for the three trace elements is somewhat more apparent (table 11), especially in regard to bottom arsenic versus bottom iron. Analysis of both the dissolved association and the bottom-sediment association indicates a common source or mechanism of formation for members of each of the two groups at sites affected by upstream sources of water-quality degradation.

Table 11.--Possible relationships between trace elements in stream-bottom sediments, Yampa River basin, August-September 1975

\begin{tabular}{|c|c|c|c|}
\hline & \multirow[t]{2}{*}{ Variables } & \multicolumn{2}{|c|}{$\begin{array}{l}\text { Percentage of variation } \\
\text { explained (number of paired } \\
\text { analyses in parentheses }{ }^{l} \text { ) }\end{array}$} \\
\hline & & $\begin{array}{c}\overline{A l l} \\
\text { sites }\end{array}$ & $\begin{array}{l}\text { Sites where ambient } \\
\text { conditions exist }\end{array}$ \\
\hline Bottom arsenic-..- & Bottom iron- & $90(48)$ & $33(43)$ \\
\hline Bottom nickel----- & Bottom iron--- & $71(48)$ & $26(43)$ \\
\hline Bottom arsenic---- & Bottom nickel--..- & $71(48)$ & $16(43)$ \\
\hline
\end{tabular}

The number of paired analyses decreases from "all sites" to "sites where ambient conditions exist" because of the elimination of the five sites noted on page 63 .

of the potential trace-element relationships discussed so far, the results have been that those elements that are correlated for all sites (including sites affected by upstream water-quality degradation) are not correlated for only those sites where ambient conditions exist. The opposite relationship exists between suspended iron and suspended manganese. The correlation coefficient for sites where ambient conditions exist is 0.67 (the largest value in the matrix); but when all sites are included, the correlation coefficient decreases to 0.26 . This would seem to indicate that the background sources of these two trace-element forms are similar; whereas, increases greater than ambient conditions are unrelated. 
Nutrients

Concentrations of dissolved and total nitrogen and phosphorus and dissolved and suspended organic carbon (Brown and others, 1970) were determined in water samples collected during August-September 1975. Information on the precision of these concentrations is given in table 17 in the Supplemental Information section at the back of this report.

Analysis of the frequency distributions of nutrients shows that dissolved and dissolved-plus-suspended organic carbon, dissolved and totalKjeldahl nitrogen, and dissolved phosphorus tend to approach log-normality. Dissolved and total nitrite plus nitrate, and total phosphorus are not adequately defined by either normal or log-normal distributions. Frequency distributions for all dissolved and total nutrients are included in the Supplemental Information section. Mean values were determined by including all sites except $Y-21, Y-26, Y-46, Y-54$, and $Y-68$, as discussed on previous and following pages.

An examination of the nutrient data using the outlier-analysis technique indicates several areas of upstream sources of water-quality degradation in terms of potentially excessive fertilization. Water in Stinking Gulch sampled at site $\mathrm{Y}-26$ ( $f \mathrm{ig}$. 17) contained a dissolved-nitrogen concentration of $3.0 \mathrm{mg} / \mathrm{L}$ as nitrogen, mostly in the form of nitrite plus nitrate. This lends credence to the conclusion reached previously regarding the existence of possible contamination upstream from this site. Site $\mathrm{Y}-46$ ( $\mathrm{fig}$. 17) had a dissolved-phosphorus concentration of $0.17 \mathrm{mg} / \mathrm{L}$ as $P$, which is believed to have resulted from the addition of phosphorus to the Hayden Powerplant cooling towers to inhibit corrosion and scaling (Stratton and Lee, 1975). Water at site Y-54 (fig. 17)--a control for mining effects on the Foidel Creek drainage--showed a concentration of total phosphorus of $0.46 \mathrm{mg} / \mathrm{L}$ as phosphorus, most of which was in the suspended phase. Again, it should be remembered that there was no continuous surface flow in the vicinity of site $Y-54$ at the time the sample was collected ( $p$. 55).

In addition to the above, Oak Creek in the vicinity of the Oak Creek drain had relatively large nutrient concentrations compared to upstream control sites. Just upstream from the drain at site $Y-69$ (fig. 1), the stream had $0.50 \mathrm{mg} / \mathrm{L}$ of suspended $\mathrm{nitrogen}$ and $0.63 \mathrm{mg} / \mathrm{L}$ of dissolved nitrogen. These concentrations may have been due in part to effluent discharged to the stream from the town of Oak Creek's wastewater-treatment plant, which is approximately $1 \mathrm{mi}(1.6 \mathrm{~km})$ upstream from the sampling point. The drain (site $Y-68$, figs. 1 and 17) also contained $0.81 \mathrm{mg} / \mathrm{L}$ of dissolved nitrogen and $14 \mathrm{mg} / \mathrm{L}$ of dissolved organic carbon, so it was not surprising to find that the concentrations of these constituents were still relatively large at site $Y-67$ (fig. 1), downstream on Oak Creek. Nitrogen concentrations near the confluence of Oak Creek with the Yampa River (site Y-66, fig. 1) had decreased to approximately ambient concentrations observed above the drain, but concentrations of organic carbon did not decrease significantly until site Y-64, after dilution by the Yampa River. 
Dissolved oxygen was measured at all 82 sites during the August-September 1975 reconnaissance. One measurement had to be discarded. Three of the measurements (sites $\mathrm{Y}-42 \mathrm{~A}, \mathrm{Y}-48$, and $\mathrm{Y}-54, \mathrm{fig} .1$ ) were less than the minimum allowable limit of $6 \mathrm{mg} / \mathrm{L}$ for cold-water biota (table 5); whereas, only two measurements (sites $\mathrm{Y}-42 \mathrm{~A}$ and $\mathrm{Y}-54$ ) were less than the minimum limit of $5 \mathrm{mg} / \mathrm{L}$ applicable to warm-water biota. The value of $3.6 \mathrm{mg} / \mathrm{L}$ at site $\mathrm{Y}-54$, although the smallest measured concentration, can be explained by the lack of reaeration at this site; there was no continuous surface flow at this site during the basinwide reconnaissance (see p. 55). The dissolved-oxygen concentration at site $Y-42 \mathrm{~A}$ was $4.7 \mathrm{mg} / \mathrm{L}$, and at site $\mathrm{Y}-48$ it was $5.9 \mathrm{mg} / \mathrm{L}$.

The solubility of oxygen in water decreases with increasing altitude and with increasing water temperature. Thus, it is theoretically possible for the saturation value of dissolved oxygen to be less than the $6-\mathrm{mg} / \mathrm{L} 1 \mathrm{imit}$ cited above. During the August-September 1975 reconnaissance, this did not occur. Dissolved oxygen ranged from 44 to 162 percent of saturation, and 57 of 81 values were greater than 100 percent of saturation. The minimum percentage of saturation occurred at site $Y-54$, which also was the site of the minimum dissolved-oxygen concentration.

\section{Biology}

A Surber sampler (Greeson and others, 1977, p. 172-173) was used to collect three samples of the benthic-macroinvertebrate community at each of 72 stream sites in the Yampa River basin during August-September 1975. The three samples from each site were composited and analyzed as one. Three Ekman-dredge (Greeson and others, 1977, p. 148) samples were collected and composited at each of eight sites that were unsuitable for use of the Surber sampler. The periphyton community was sampled using three plastic strips tied to stakes (Greeson and others, 1977, p. 129-130) in the stream bottom at each site. These strips were allowed to colonize for approximately 5 weeks; strips were recovered at 61 of 74 sites.

As part of the analysis performed on the benthic-macroinvertebrate samples, diversity indices were computed using the formula given by Slack, Averett, Greeson, and Lipscomb (1973):

$$
\bar{d}=-\sum_{i=1}^{t}\left(\frac{n}{n}\right) \log _{2}\left(\frac{n_{i}}{n}\right),
$$

where $\bar{d}=$ diversity per individual;

$n=$ total number of individuals;

$n_{i}=$ number of individuals in each taxon $i$; and

$t=$ number of taxa. 
The calculations were made at the genus level. According to Wilhm and Dorris (1968), values of $\bar{d} 11 * *$ less than 1 have been obtained in areas of heavy pollution, values from 1 to 3 in areas of moderate pollution, and values exceeding 3 in clean water areas." When plotted in the form of a histogram (fig. 25A), the distribution of $\bar{d}$ for the Surber samples from the basinwide reconnaissance is seen to be negatively skewed. Results are shown for only 61 samples, as 11 samples were lost in the laboratory.

Fifty-seven percent of the $\bar{d}$ values from Surber samples measured as part of the basinwide reconnaissance were greater than 3 . Only two values of $\bar{d}$, at sites $Y-24$ and $Y-76$ ( $f$ ig. 1 ), were less than 1 . Of these, results at site Y-76 appear to result from stream-discharge conditions at this site. Site Y-76 is located just downstream from the outflow of Yampa Reservoir (fig. 1). The channel slope is very steep at this point, and the stream is swift and turbulent. Because of these conditions, many bottom-dwelling organisms are precluded. However, black-fly larvae, which have a suction mechanism for attachment to the substrate, are ideally suited to this environment and are prolific at this site. The second largest number of organisms $(1,014$; fig. 25B) and the largest biomass $\left(99 \mathrm{~g} / \mathrm{m}^{2}\right.$, grams per square meter, wet weight; fig. $25 \mathrm{C}$ ) were measured at this site. Black-fly larvae accounted for 99 percent of both values. The next highest biomass measured from a Surber sample was $22 \mathrm{~g} / \mathrm{m}^{2}$, and 59 of 61 determinations were $13 \mathrm{~g} / \mathrm{m}^{2}$ or less (fig. 25C).

Physical conditions at site $\mathrm{Y}-24$ al so could have accounted for the small value of $\bar{d}$ at this site. Stream discharge was less than $0.1 \mathrm{ft}^{3} / \mathrm{s}$ $\left(0.003 \mathrm{~m}^{3} / \mathrm{s}\right)$, water temperature was $23.0^{\circ} \mathrm{C}$, and specific conductance was 1,100 umhos. It is possible that the stream is ephemeral.

During September 22-26, 1975, Eddy (1975) studied the benthic-macroinvertebrate community of the main-stem Yampa River from Steamboat Springs to Hayden, Colo. (fig. 1). He found that $\bar{d}$ values throughout the study area decreased immediately downstream from municipal-waste discharges. Five of the Yampa River sites sampled by Eddy (1975) also were sampled during the basinwide reconnaissance. The data collected at these sites (sites $Y-44, Y-45$, $Y-47, Y-63$, and $Y-64$, fig. 1) are summarized in table 12.

The range of $\bar{d}$ for the five sites as determined by Eddy (1975) was 2.50 to 3.62 ; whereas, a much smaller range (3.15 to 3.50$)$ with a larger average value was recorded during the basinwide reconnaissance. The primary reason for the differences in $\bar{d}$ is the difference in mesh size of the Surber-sampler nets used in the two studies. The Surber samplers used during the basinwide reconnaissance were equipped with the standard supplied net having about 1,000-micrometer openings. Eddy (1975) used a surber sampler that had been modified by replacing the original net with a 207-micrometer mesh net. Eddy's (1975) samples contained many more individuals than those collected during the basinwide reconnaissance, even though the numbers of genera often were similar (table 12). The additional organisms collected by Eddy (1975) were primarily very small midges, caddisflies, and mayflies. 

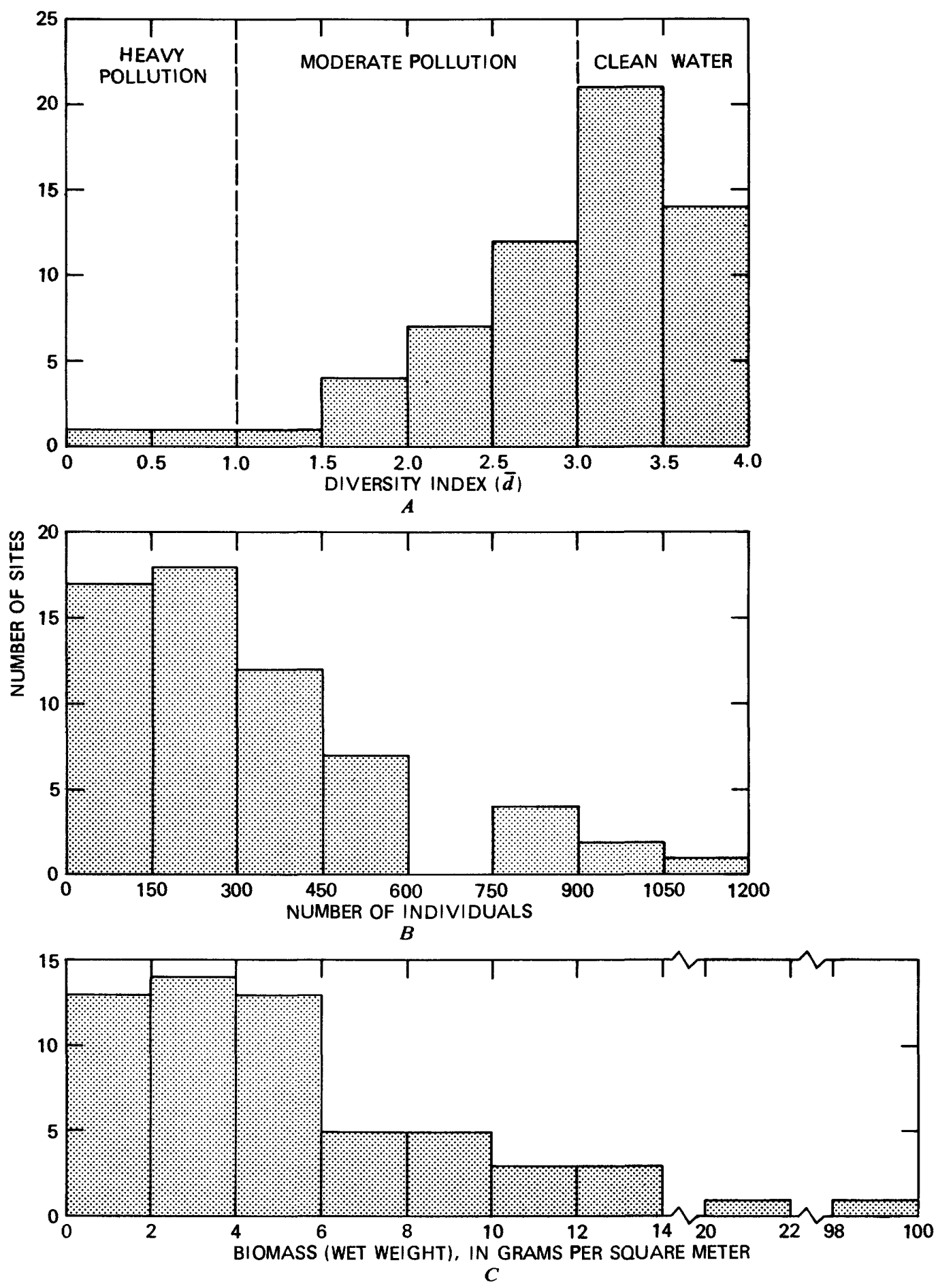

Figure 25.-- Frequency distributions of benthic macroinvertebrates in streams of the Yampa River basin, August-September 1975. (The classifications heavy pollution, moderate pollution, and clean water are from Wilhm and Dorris, 1968.) 
Table 12.--Comparison of benthic-macroinvertebrate data collected from the Yampa River during August-September 1975 and data reported by Eddy (1975)

\begin{tabular}{|c|c|c|c|c|c|c|}
\hline \multirow[b]{2}{*}{ Site ${ }^{1}$} & \multicolumn{2}{|c|}{ Diversity index $(\bar{d})$} & \multicolumn{2}{|c|}{$\begin{array}{c}\text { Number of organisms } \\
\text { per square meter }\end{array}$} & \multicolumn{2}{|c|}{$\begin{array}{l}\text { Number of genera } \\
\text { per square meter }\end{array}$} \\
\hline & naissance ${ }^{2}$ & $\begin{array}{l}\text { Eddy } \\
(1975)^{2}\end{array}$ & $\begin{array}{c}\text { Basinwide } \\
\text { recon- } \\
\text { naissance }{ }^{2}\end{array}$ & $\begin{array}{l}\text { Eddy } \\
(1975)^{2}\end{array}$ & $\begin{array}{l}\text { Basinwide } \\
\text { recon- } \\
\text { naissance } 3\end{array}$ & $\begin{array}{l}\text { Eddy } \\
(1975)^{2}\end{array}$ \\
\hline$Y-44(14)--$ & 3.15 & 2.69 & 1,180 & 30,727 & 21 & 29 \\
\hline$Y-45(13)--$ & 3.41 & 3.62 & 840 & 10,175 & 19 & 28 \\
\hline$Y-47(11)--$ & 3.17 & 3.19 & 3,300 & 1,711 & 22 & 18 \\
\hline$Y-63(6)---$ & 3.29 & 2.50 & 1,150 & 15,839 & 19 & 23 \\
\hline$Y-64(1)-\cdots$ & 3.50 & 2.66 & 699 & 9,784 & 21 & 19 \\
\hline
\end{tabular}

${ }^{l}$ Eddy's (1975) station designation in parentheses.

2 Mean of three samples.

${ }^{3}$ Total in three samples.

Ames (1977) in August and September 1975 also sampled benthic macroinvertebrates at four sites on the Yampa River where samples were collected during the basinwide reconnaissance. Although a kick-sampling technique was used, the mesh size of the net was $1,000 \cdot 700$ micrometers, which is comparable to the Surber-sampler nets used during the basinwide reconnaissance. The values of $\bar{d}$ are compared below:

Site s $^{1}$

Diversity index $(\bar{d})$

Basinwide reconnaissance

Ames $(1977)^{2}$

\begin{tabular}{|c|c|c|c|}
\hline $\begin{array}{l}Y-17 \\
Y-38 B \\
Y-44 \\
Y-71\end{array}$ & $\begin{array}{l}\text { (Y5) } \\
(\text { (Y })(Y 3) \\
\text { (Y1) }\end{array}$ & $\begin{array}{l}2.53 \\
3.38 \\
3.15 \\
3.74\end{array}$ & $\begin{array}{l}3.16-3.27 \\
3.43-4.17 \\
3.08-3.29 \\
3.43-3.78\end{array}$ \\
\hline
\end{tabular}

${ }^{1}$ Ames' (1977) station designation in parentheses.

${ }^{2}$ Two samples, one in August 1975 and one in September 1975.

With the exception of site $Y-17$ (fig. 1), the values of $\bar{d}$ are quite similar. 
Changes in the benthic-macroinvertebrate community along the Yampa River are shown on figure 26. Dashed 1 ines are used to connect the most upstream site, $Y-76$ (fig. 1), with the rest of the data because of the unusual conditions at site $Y-76$ during the basinwide reconnaissance $(p .69)$. If this site is disregarded, a general downstream decrease in number of genera, number of individuals, biomass, and $\bar{d}$ is noted during August-September 1975. The downstream decrease in number of individuals is somewhat in contrast to the results of Ames (1977), who noted a maximum in the average number of aquatic insects collected from July 1975 to October 1976 at site Y-45, which is $145 \mathrm{mi}(233 \mathrm{~km})$ upstream from the mouth of the Yampa River. Ames (1977) data also are plotted on figure 26; they corroborate the lower numbers of individuals in the downstream reaches of the Yampa River found during the basinwide reconnaissance.

Canton and Ward (1977) used a Surber sampler with a 700-micrometer mesh net to study the effects of an active strip mine on the benthic macroinvertebrates of Trout Creek from July 1975 to June 1976. They found a downstream increase in standing crop and no definite evidence of stressed conditions in the macroinvertebrate community. Surber samples collected during the basinwide reconnaissance at site $Y-57$ ( $\mathrm{fig} .1), 9.1 \mathrm{mi}(15 \mathrm{~km})$ upstream from the most upstream site sampled by Canton and Ward (1977), and at site Y-56, $1.5 \mathrm{mi}(2.4 \mathrm{~km})$ downstream from the most downstream site sampled by Canton and Ward (1977), also showed a downstream increase in standing crop. Total numbers of organisms collected during the basinwide reconnaissance were 0.4 to 0.5 times those collected by Canton and Ward (1977), but values of $\bar{d}$ were similar:

\begin{tabular}{|c|c|c|c|c|}
\hline \multirow{2}{*}{$\begin{array}{l}\text { Site on } \\
\text { Trout Creek }\end{array}$} & \multicolumn{2}{|c|}{ Diversity index $(\bar{d})$} & \multicolumn{2}{|c|}{$\begin{array}{c}\text { Number of organisms } \\
\text { per square meter }\end{array}$} \\
\hline & $\begin{array}{l}\text { Basinwide } \\
\text { reconna is- } \\
\text { sance }\end{array}$ & $\begin{array}{c}\text { Canton and } \\
\text { Ward }(1977)^{2}\end{array}$ & $\begin{array}{l}\text { Basinwide } \\
\text { reconnaissance }\end{array}$ & $\begin{array}{l}\text { Canton and } \\
\text { Ward }(1977)^{2}\end{array}$ \\
\hline Downst ream ${ }^{3}-\ldots--$ & $3 \cdot 31$ & $2.9-4.0$ & 2,740 & 7,089 \\
\hline Upstream ${ }^{4}$ & 3.56 & $3.1-4.1$ & 1,500 & 2,930 \\
\hline
\end{tabular}

${ }^{1}$ Mean of three samples collected during August 1975.

${ }^{2}$ Annual mean values.

${ }^{3}$ Basinwide reconnaissance site $(Y-56$, fig. 1) is $1.5 \mathrm{mi}(2.4 \mathrm{~km})$ downstream from site sampled by Canton and Ward (1977).

${ }^{4}$ Basinwide reconnaissance site $(Y-57, \mathrm{fig} .1)$ is $9.1 \mathrm{mi}(15 \mathrm{~km})$ upstream from site sampled by Canton and Ward (1977). 
DISTANCE UPSTREAM FROM MOUTH OF YAMPA RIVER, IN KILOMETERS
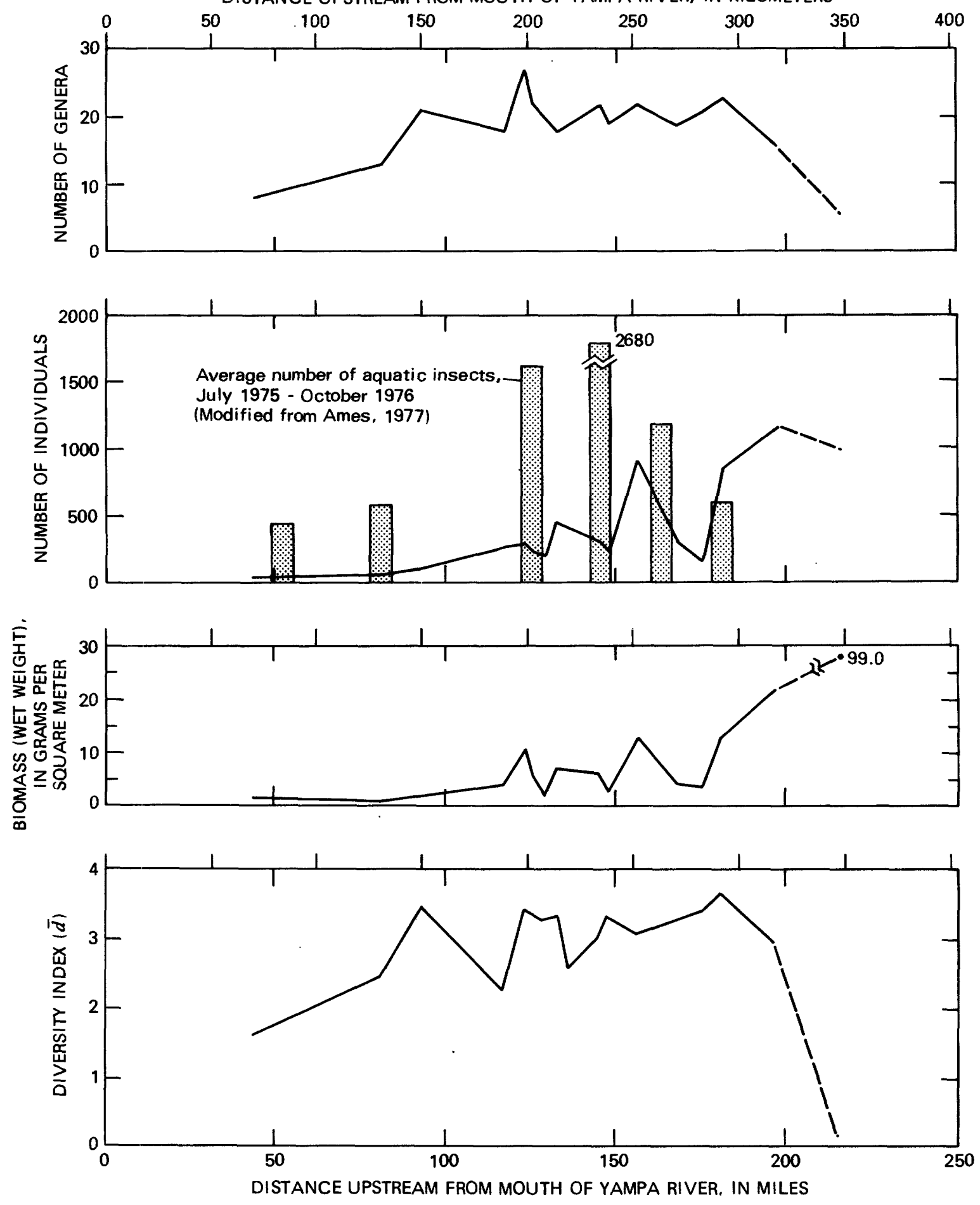

Figure 26.--Stream-reach profiles of benthic macroinvertebrates in the Yampa River, August-September 1975. (Dashed lines connect the most upstream site, Y-76, with the rest of the data, because of the unusual conditions at site $Y-76$.) 
Two of the Ekman-dredge samples collected during the August-September 1975 reconnaissance were lost in the laboratory, so only six values of $\bar{d}$ are available for discussion. These are not directly comparable to values of $\bar{d}$ computed for Surber samples, because of the differences in collection techniques.

The value of $\bar{d}$ for Ekman-dredge samples collected from Sage Creek decreased from 2.23 at site $Y-46 \mathrm{~A}$ (fig. 1) upstream from the Hayden Powerplant to 0.92 at site $Y-46$ downstream from the powerplant. Biomass (wet-weight) values were $4.6 \mathrm{~g} / \mathrm{m}^{2}$ at the upstream site and $0.14 \mathrm{~g} / \mathrm{m}^{2}$ at the downstream site. This indicates an adverse effect on water quality due to the powerplant and corroborates results from dissolved, total, and bottomsediment trace-element data discussed previously.

Ekman-dredge samples also were collected from Grassy Creek. The $\bar{d}$ value of 0.21 at site $Y-48$ ( $f$ ig. 1) may be partly a result of the surface coalmining operations in the drainage upstream from this site. However, at site $\mathrm{Y}-49$, on Grassy Creek upstream from the mining operation, the value of $\bar{d}$ was only 1.19. These values of $\bar{d}$ probably also are influenced by the low flows at these sites (estimated to be $0.1 \mathrm{ft}^{3} / \mathrm{s}$ or $0.003 \mathrm{~m}^{3} / \mathrm{s}$ at site $\mathrm{Y}-48$ and $0.01 \mathrm{ft}^{3} / \mathrm{s}$ or $0.0003 \mathrm{~m}^{3} / \mathrm{s}$ at site $\left.\mathrm{Y}-49\right)$. For comparison, the wet weight of the biomass decreased from $46 \mathrm{~g} / \mathrm{m}^{2}$ at site $Y-49$ to $5.6 \mathrm{~g} / \mathrm{m}^{2}$ at site $Y-48$, and the number of genera decreased from 9 at site $Y-49$ to 4 at site $Y-48$. These data again indicate a possible effect on the stream ecology downstream from the coal-mining operation.

Finally, values of $\bar{d}$ from Ekman-dredge samples decreased from 2.86 at site $Y-70$ ( $f i g .1$ ) on Oak Creek to 2.22 at $Y-69$, indicating little effect of the 0ak Creek sewage-treatment plant. Wet-weight biomass values decreased from $75 \mathrm{~g} / \mathrm{m}^{2}$ at the upstream site to $4.9 \mathrm{~g} / \mathrm{m}^{2}$ at the downstream site, just the opposite of what might be expected from the increased nutrient concentrations (see p. 67) at the downstream site. Physical conditions--a change from an upstream sand-gravel channel bottom to a downstream silt-sand channel bottom--may be contributing to the decreased biomass at the downstream site.

Water-quality characteristics at four sites (sites $Y-26, Y-46, Y-54$, and $\mathrm{Y}-68$, fig. 17) were indicative of upstream water-quality degradation based upon the outlier analysis of trace-element concentrations in water and stream-bottom sediments and of nutrient concentrations in water. Although a definite adverse effect on benthic-macroinvertebrate diversity was determined at site $Y-46$, the same was not true of site $Y-26$. The value of $\bar{d}$ for a Surber sample collected at this site was 2.28 , although only 78 organisms were found and these constituted a wet-weight biomass of only $3.1 \mathrm{~g} / \mathrm{m}^{2}$. The Surber sample from site $Y-68$ was one of those lost in the laboratory, so no information is available for this site. No benthic-macroinvertebrate sample was collected at site $\mathrm{Y}-54$ because of the unusual streamflow conditions (p. 55). At site $Y-21$, where sodium and chloride concentrations have been determined to be outliers because of suspected irrigation return flow, biological conditions indicated no adverse effect on stream quality. 
Frequency distributions for periphyton biomass (dry weight and organic weight) are shown on figure 27. The distributions are positively skewed, and they are very similar to each other and to the numbers and biomass distributions for benthic macroinvertebrates (figs. $25 B$ and 25C). Periphyton-biomass values did not indicate any areas significantly affected by upstream waterquality degradation in the Yampa River basin during August-September 1975.

\section{Ambient Stream Quality}

Based on the analysis of data collected during the August-September 1975 basinwide reconnaissance, maximum likely ambient concentrations of selected chemical constituents in streams of the Yampa River basin have been determined. Application of the procedure in this context was used by Wentz (1974b) for detecting impacts of metal mining on Colorado streams. The maximum likely ambient concentration for a given constituent is defined herein as the mean plus twice the standard deviation $(\bar{x}+2 s)$ for data obtained at sites where water was determined to be unaffected by upstream water-quality degradation. This includes all sites except $\mathrm{Y}-21, \mathrm{Y}-26, \gamma-46, \gamma-54$, and $\mathrm{Y}-68$ (figs. 1 and 17). The maximum likely ambient concentrations are not to be confused with, nor are they determined from, maximum likelihood concepts of statistical analysis.

A summary of the maximum likely ambient concentrations of chemical constituents in streams of the Yampa River basin is given in table 13. These values are revisions of those originally presented by Wentz and Steele (1978). The values are applicable only for the period of data collection, August-September 1975. The sample values used to determine these upper limits contain inherent randomness, although an attempt to account for this is embodied in the inclusion of the standard deviation into the limit. It is believed by the authors that the values in table 13 provide a first approximation to the maximum concentrations to be expected in streams of the Yampa River basin prior to extensive coal-resource development.

\section{Seasonal Variations in Stream Quality}

During the quarterly sampling program, streamflow, water temperature, $\mathrm{pH}$, dissolved oxygen, and specific conductance were measured, and turbidity, suspended sediment, total- and fecal-coliform bacteria, and 5-day biochemical oxygen demand $\left(\mathrm{BOD}_{5}\right)$ were determined from water samples collected at sites $\mathrm{Y}-42 \mathrm{~B}, \mathrm{Y}-62 \mathrm{~B}, \mathrm{Y}-64 \mathrm{~B}, \mathrm{Y}-64 \mathrm{C}$, and $\mathrm{Y}-71 \mathrm{~A}$ (fig. 1) (U.S. Geological Survey, 1976). In addition to the above constituents, dissolved and total nitrogen and phosphorus were determined from water samples collected at sites $Y-58 A$, $\mathrm{Y}-63 \mathrm{~A}, \quad \mathrm{Y}-64 \mathrm{~A}, \mathrm{Y}-65 \mathrm{~A}, \mathrm{Y}-69, \mathrm{Y}-71 \mathrm{~B}$, and $\mathrm{Y}-72$ (fig. 1) (U.S. Geological Survey, 1976). Water samples from the remaining 30 sites (see p. 5 and table 1) were analyzed for the same constituents as during the basinwide reconnaissance, with the following exceptions: Dissolved and total antimony and arsenic were analyzed in water at all sites during all sampling periods; selenium and silver were analyzed in stream-bottom sediments collected during December 1975; 


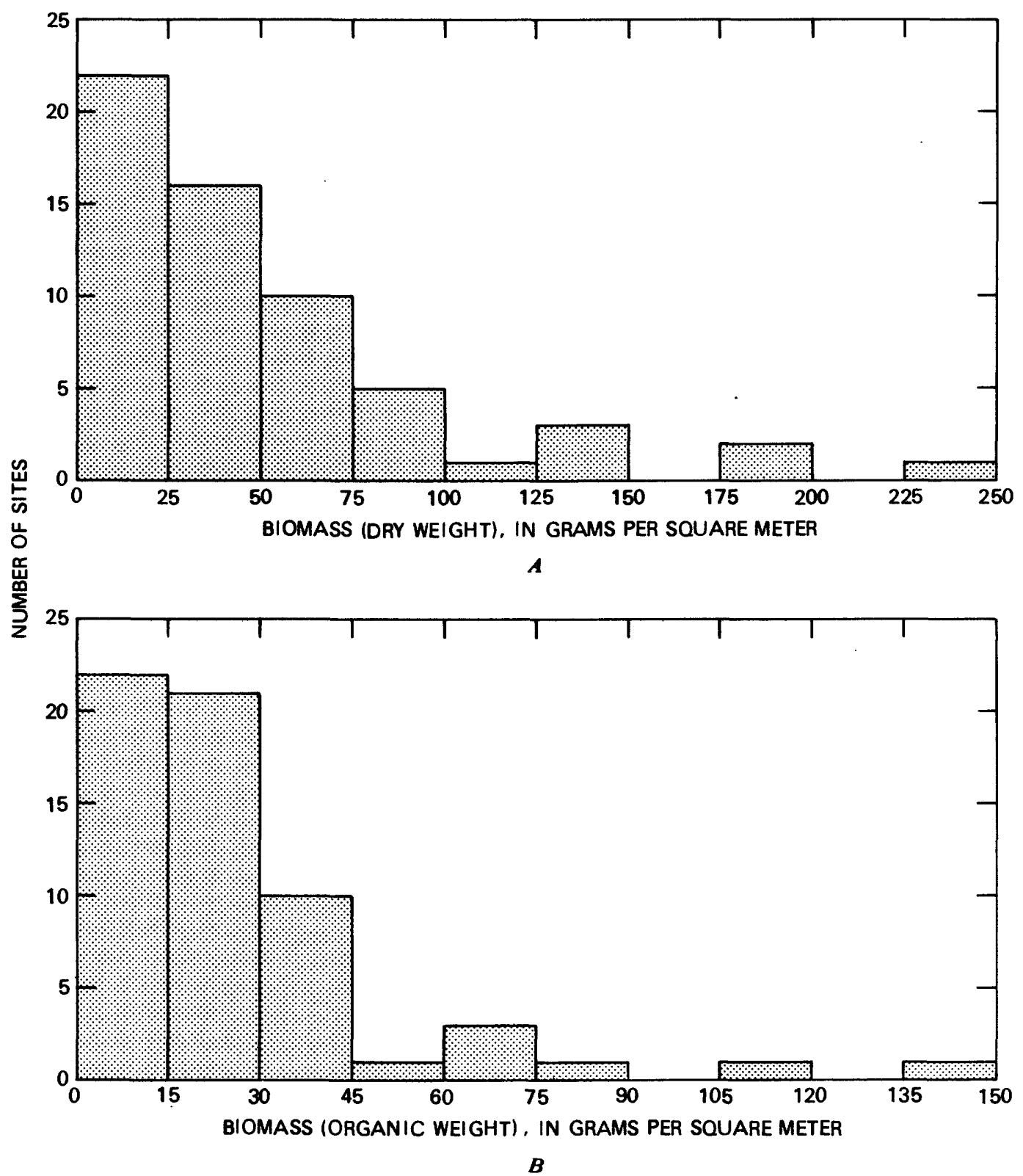

Figure 27.-- Frequency distributions of periphyton in streams of the Yampa River basin, August-September 1975. 
Table 13.--Maximum likely ambient concentrations of chemical constituents in streams of the Yampa River basin, August-September 1975

[Modified from Wentz and Steele, 1978]

\begin{tabular}{|c|c|c|}
\hline Constituent & $\begin{array}{c}\text { Number } \\
\text { of } \\
\text { analyses }\end{array}$ & $\begin{array}{c}\text { Concen- } \\
\text { tration } \\
(x+2 s) \\
\end{array}$ \\
\hline $\begin{array}{l}\text { Specific conductance, micromhos per centimeter at } 25^{\circ} \mathrm{C} \\
\text { Dissolved solids, } \mathrm{mg} / \mathrm{L} \text { (milligrams per liter) } \\
\text { Total hardness, } \mathrm{mg} / \mathrm{L} \text { as calcium carbonate } \\
\text { Calcium, } \mathrm{mg} / \mathrm{L} \\
\text { Magnesium, } \mathrm{mg} / \mathrm{L}\end{array}$ & $\begin{array}{l}77 \\
28 \\
28 \\
28 \\
28\end{array}$ & $\begin{array}{r}1,700 \\
660 \\
440 \\
97 \\
51\end{array}$ \\
\hline $\begin{array}{l}\text { Potassium, mg/l } \\
\text { Sodium, mg/l } \\
\text { Bi carbonate, mg/l } \\
\text { Ch loride, mg/l } \\
\text { Fluoride, mg/L }\end{array}$ & $\begin{array}{l}28 \\
28 \\
28 \\
28 \\
28\end{array}$ & $\begin{array}{r}4.5 \\
85 \\
360 \\
21 \\
.42\end{array}$ \\
\hline $\begin{array}{l}\text { Sulfate, } \mathrm{mg} / \mathrm{L} \\
\text { Silica, } \mathrm{mg} / \mathrm{L} \\
\text { Dissolved organic carbon, } \mathrm{mg} / \mathrm{L} \\
\text { Dissolved plus suspended organic carbon, mg/ } \\
\text { Dissolved Kjeldahl nitrogen, } \mathrm{mg} / \mathrm{L} \text { as } \mathrm{N}\end{array}$ & $\begin{array}{l}30 \\
28 \\
75 \\
75 \\
75\end{array}$ & $\begin{array}{r}250 \\
21 \\
21 \\
22 \\
\quad .49\end{array}$ \\
\hline $\begin{array}{l}\text { Total Kjeldahl nitrogen, } \mathrm{mg} / \mathrm{L} \text { as } \\
\text { Dissolved nitrite plus nitrate, } \mathrm{mg} / \mathrm{L} \text { as } \\
\text { Total nitrite plus nitrate, } \mathrm{mg} / \mathrm{L} \text { as } \\
\text { Dissolved phosphorus, } \mathrm{mg} / \mathrm{L} \text { as } \mathrm{P} \\
\text { Total phosphorus, mg/L as } \mathrm{P}\end{array}$ & $\begin{array}{l}75 \\
75 \\
75 \\
75 \\
75\end{array}$ & $\begin{array}{l}.69 \\
.21 \\
.21 \\
.067 \\
.13\end{array}$ \\
\hline $\begin{array}{l}\text { Dissolved cadmium, } \mu \mathrm{g} / \mathrm{L} \text { (micrograms per liter) } \\
\text { Total cadmium, } \mu \mathrm{g} / \mathrm{L} \\
\text { Dissolved cobalt, } \mu \mathrm{g} / \mathrm{L} \\
\text { Total cobalt, } \mu \mathrm{g} / \mathrm{L} \\
\text { Dissolved copper, } \mu \mathrm{g} / \mathrm{L}\end{array}$ & $\begin{array}{l}77 \\
77 \\
77 \\
76 \\
77\end{array}$ & $\begin{array}{l}0 \\
(1) \\
62 \\
3.0\end{array}$ \\
\hline $\begin{array}{l}\text { Total copper, } \mu \mathrm{g} / \mathrm{L} \\
\text { Dissolved iron, } \mu \mathrm{g} / \mathrm{L} \\
\text { Total iron, } \mu \mathrm{g} / \mathrm{L} \\
\text { Dissolved lead, } \mu \mathrm{g} / \mathrm{L} \\
\text { Total lead, } \mu \mathrm{g} / \mathrm{L}\end{array}$ & $\begin{array}{l}75 \\
77 \\
77 \\
77 \\
76\end{array}$ & $\begin{array}{c}18 \\
160 \\
1,900 \\
1 j^{4}\end{array}$ \\
\hline $\begin{array}{l}\text { Dissolved manganese, } \mu \mathrm{g} / \mathrm{L} \\
\text { Total manganese, } \mu \mathrm{g} / \mathrm{L} \\
\text { Dissolved mercury, } \mu \mathrm{g} / \mathrm{L} \\
\text { Total mercury, } \mu \mathrm{g} / \mathrm{L} \\
\text { Dissolved nickel, } \mu \mathrm{g} / \mathrm{L}\end{array}$ & $\begin{array}{l}77 \\
76 \\
77 \\
77 \\
77\end{array}$ & $\begin{array}{l}220 \\
310 \\
.067 \\
.10 \\
4.4\end{array}$ \\
\hline
\end{tabular}


Table 13.--Maximum likely ambient concentrations of chemical constituents in streams of the Yampa River basin, August-September 1975--Continued

\begin{tabular}{|c|c|c|}
\hline Const ituent & $\begin{array}{l}\text { Number } \\
\text { of } \\
\text { analyses }\end{array}$ & $\begin{array}{l}\text { Concen- } \\
\text { tration } \\
(x+2 s) \\
\end{array}$ \\
\hline $\begin{array}{l}\text { Total nickel, } \mu \mathrm{g} / \mathrm{L} \\
\text { Dissolved selen } \mathrm{um}, \mu \mathrm{g} / \mathrm{l} \\
\text { Total selenium, } \mu \mathrm{g} / \mathrm{L} \\
\text { Dissolved vanadium, } \mu \mathrm{g} / \mathrm{L} \\
\text { Dissolved } \mathrm{zinc}, \mu \mathrm{g} / \mathrm{L}\end{array}$ & $\begin{array}{l}76 \\
77 \\
77 \\
77 \\
77\end{array}$ & $\begin{array}{l}50 \\
2.6 \\
3.0 \\
2.7 \\
14\end{array}$ \\
\hline $\begin{array}{l}\text { Total zinc, } \mu \mathrm{g} / \mathrm{L} \\
\text { Bottom antimony, } \mu \mathrm{g} / \mathrm{g} \text { (micrograms per gram) } \\
\text { Bottom arsenic, } \mu \mathrm{g} / \mathrm{g} \\
\text { Bottom chromium, } \mu \mathrm{g} / \mathrm{g} \\
\text { Bottom copper, } \mu \mathrm{g} / \mathrm{g}\end{array}$ & $\begin{array}{l}76 \\
43 \\
43 \\
43 \\
43\end{array}$ & $\begin{array}{l}33 \\
7.0 \\
13 \\
50 \\
19\end{array}$ \\
\hline $\begin{array}{l}\text { Bottom i ron, } \mu \mathrm{g} / \mathrm{g} \\
\text { Bottom lead, } \mu \mathrm{g} / \mathrm{g} \\
\text { Bottom mercury, } \mathrm{\mu g} / \mathrm{g} \\
\text { Bottom } \mathrm{nickel}, \mu \mathrm{g} / \mathrm{g}\end{array}$ & $\begin{array}{l}43 \\
43 \\
43 \\
43\end{array}$ & $\begin{array}{l}15,000 \\
270 \\
17\end{array}$ \\
\hline
\end{tabular}

${ }^{1} \mathrm{All}$ values were $<10 \mu \mathrm{g} / \mathrm{L}$.

${ }^{2} \mathrm{All}$ values were $<100 \mu \mathrm{g} / \mathrm{L}$.

and toxic organic and radiochemical constituents were analyzed in water collected from sites $Y-1, Y-8, Y-17, Y-39, Y-47, Y-64$, and $Y-72$ (fig. 1) during June 1976 (see p. 99). Stream-bottom sediments for trace-element analysis were collected at 21 sites during December 1975, at 25 sites during March 1976, at 29 sites during June 1976, and at 30 sites during August-September 1976.

\section{Frequency Distributions}

The forms of the frequency distributions of the various stream-quality variables changed from season to season during the quarterly sampling program. These changes have been documented for August-September 1975 to August-September 1976. Additional data would be necessary to determine if the changes in the frequency distributions are generally applicable from year to year. 
Graphs showing the frequency distributions for all trace elements and nutrients are included in the Supplemental Information section at the back of this report. Selected graphs of the distributions are presented below as examples. Data collected in August-September 1975 at the 32 reconnaissance sites which were later converted to quarterly sampling sites (table 1) also are included for comparison. Mean values were determined by including all sites except $Y-26, Y-46$, and $Y-68$, as discussed in the section on outlier Analysis, page 95. Data for turbidity, total-and fecal-coliform bacteria, and $\mathrm{BOD}_{5}$ are not discussed, as these data were collected at only a few sites (U.S. Geological Survey, 1978).

Trace elements in water.--The smallest trace-element concentrations were measured in samples collected during low flows in August and September. The mean concentrations and the forms of the frequency distributions for any given dissolved or total trace element were similar for both August-September sampling periods in 1975 and 1976. The only exceptions to this generalization are dissolved vanadium, total zinc, and, possibly, dissolved cobalt.

The distributions of some trace elements, for example, total mercury (fig. 28), changed little throughout the period of study. However, many of the trace elements, such as dissolved cadmium ( $\mathrm{fig}$. 29) and total manganese (fig. 30), showed decided maximum concentrations in March 1976 . During December 1975 and June 1976, the concentrations of a few trace elements were larger than the August-September values. These larger values may or may not be associated with March maximums. For example, dissolved lead (fig. 31) shows a mean concentration in December 1975 that is intermediate between the mean concentration in August-September 1975 and the mean concentration in March 1976. A similar situation was found for total iron (fig. 32) in June 1976; however, dissolved vanadium ( $\mathrm{fig}$. 33) shows a maximum concentration in June 1976.

Reasons for the maximums that occurred in March 1976 for both dissolved and total trace-element concentrations are not apparent. The relatively large total trace-element concentrations in March apparently resulted primarily from relatively large concentrations of suspended forms. However, conditions that normally favor relatively large suspended trace-element concentrations, namely erosion due to high streamflows, generally also tend to produce relatively small dissolved trace-element concentrations because of dilution. It is true that the largest suspended-sediment concentrations were recomded in March (fig. 34). Because the sites sampled for suspended sediment d fer somewhat from the sites sampled for trace elements, it is difficult to make any firm conclusions. It also is true that the smallest pH values were measured in March 1976 (fig. 35), and this may have contributed to greater solubilization of some trace elements at this time of year. The fact that the sites sampled during the quarterly program encompass an extremely wide altitude range (from $9,550 \mathrm{ft}$ or $2,910 \mathrm{~m}$ at site $Y-65$ to $6,205 \mathrm{ft}$ or $1,890 \mathrm{~m}$ at site $Y-21, \mathrm{fig} .1$ ) and can be great distances apart (about $73 \mathrm{mi}$ or $117 \mathrm{~km}$ from sites $Y-8$ to $Y-75)$ means that $c$ limatic, and thus hydrologic, conditions can be greatly different at any two sites during the same period of time. This further complicates the analysis of the data. 
Those instances where trace-element concentrations were noted as not meeting proposed Colorado water-quality standards (table 5) are summarized in table 14. Water-use standards currently do not exist for antimony, cobalt, and vanadium. Iron and manganese again account for the majority of instances (90 percent) where water-supply standards were not met, just as they did during the basinwide reconnaissance ( $p .50)$. The trace element most frequently not meeting aquatic-life standards was cadmium (32 percent of the total number of occurrences where the standard was not met). As with mercury during the basinwide reconnaissance ( $p .48$ ), this may be due primarily to the fact that the aquatic-life standard for cadmium $(0.4 \mu \mathrm{g} / \mathrm{L})$ is less than the minimum cadmium concentration $(1 \mu \mathrm{g} / \mathrm{L})$ detectable in the U.S. Geological Survey laboratory using routine analytical procedures.
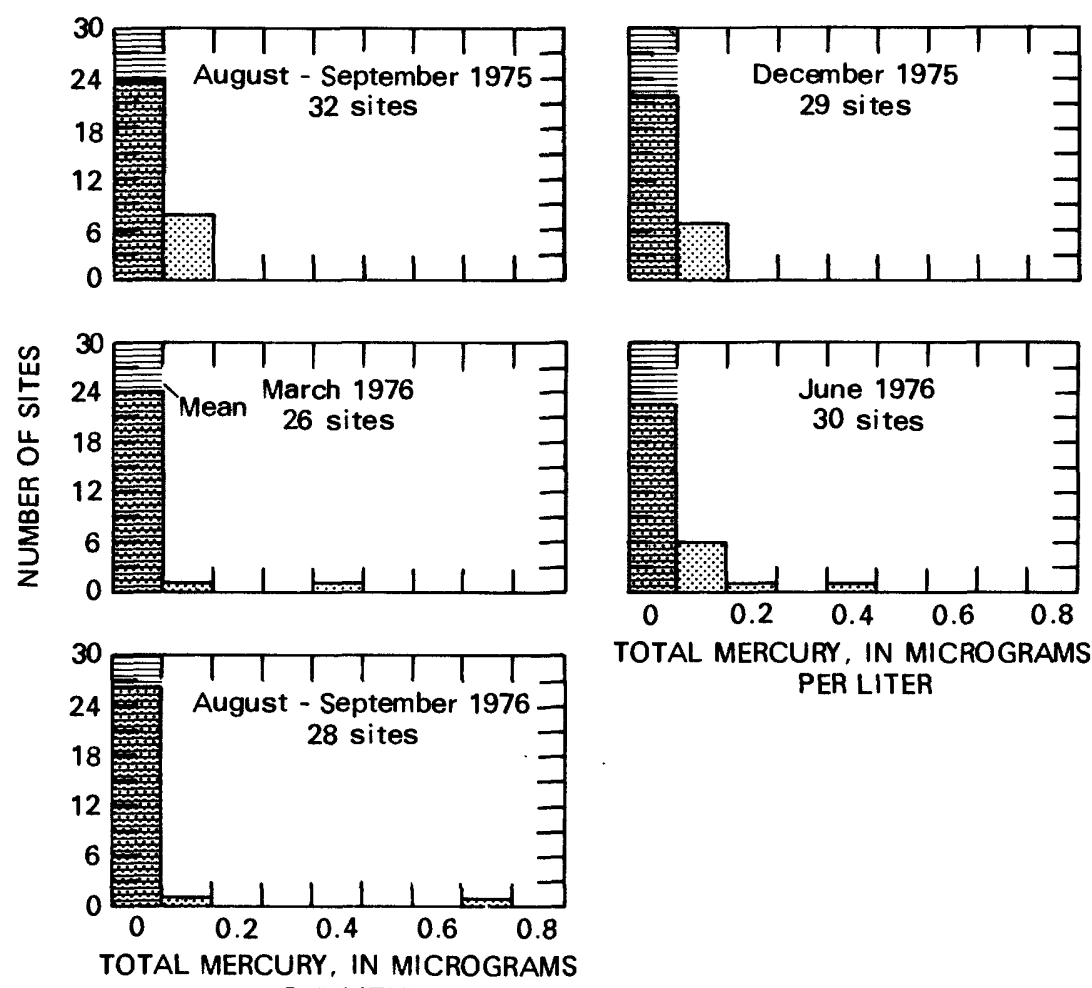

TOTAL MERCURY, IN MICROGRAMS PER LITER

Figure 28.-- Frequency distributions of total mercury in stream s of the Yampa River basin, August-September 1975 through August-September 1976. 

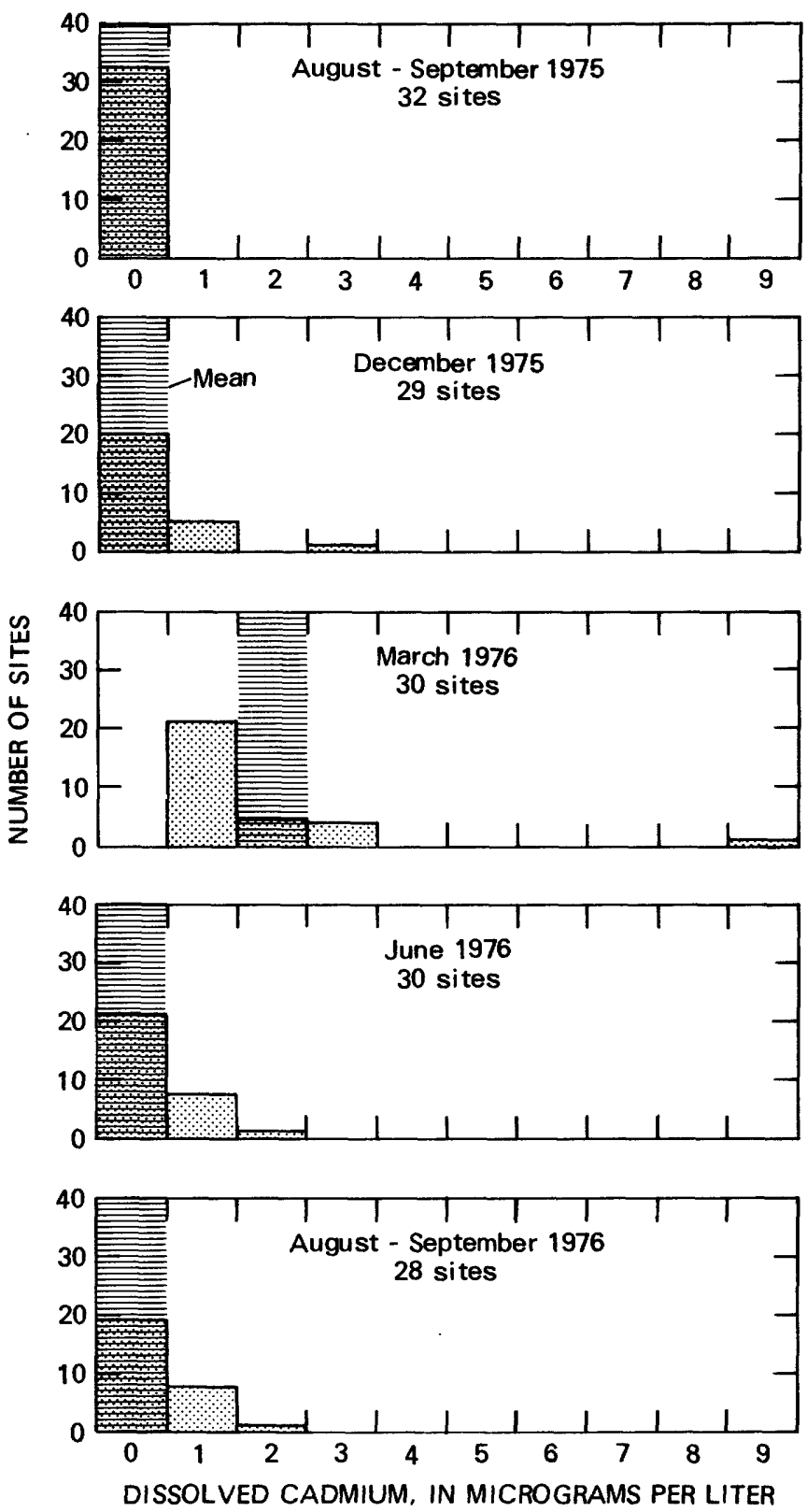

Figure 29.-- Frequency distributions of dissolved cadmium in streams of the Yampa River basin, August-September 1975 through August-September 1976. 

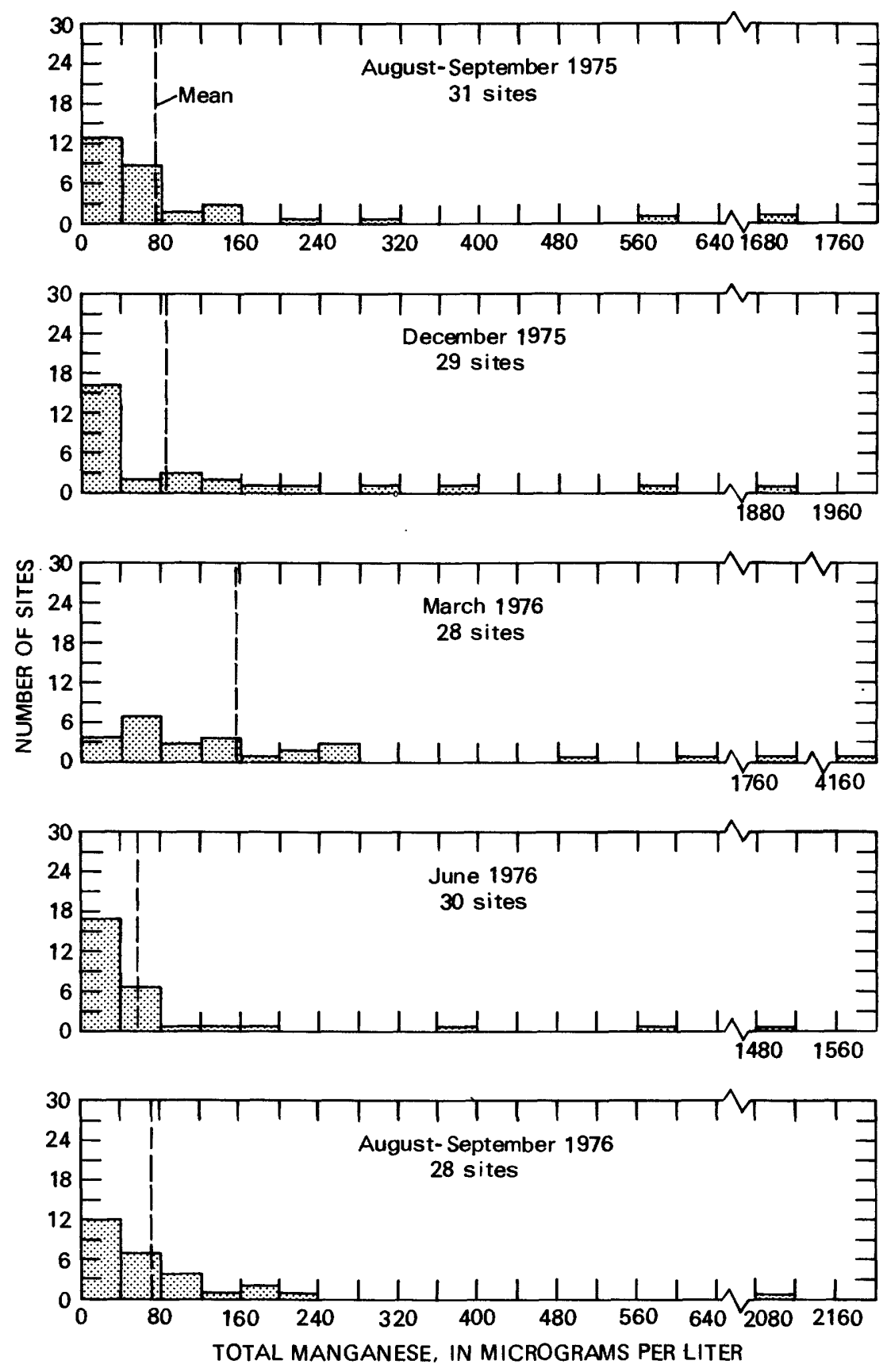

Figure 30.-- Frequency distributions of total manganese in streams of the Yampa River basin, August-September 1975 through AugustSeptember 1976. 

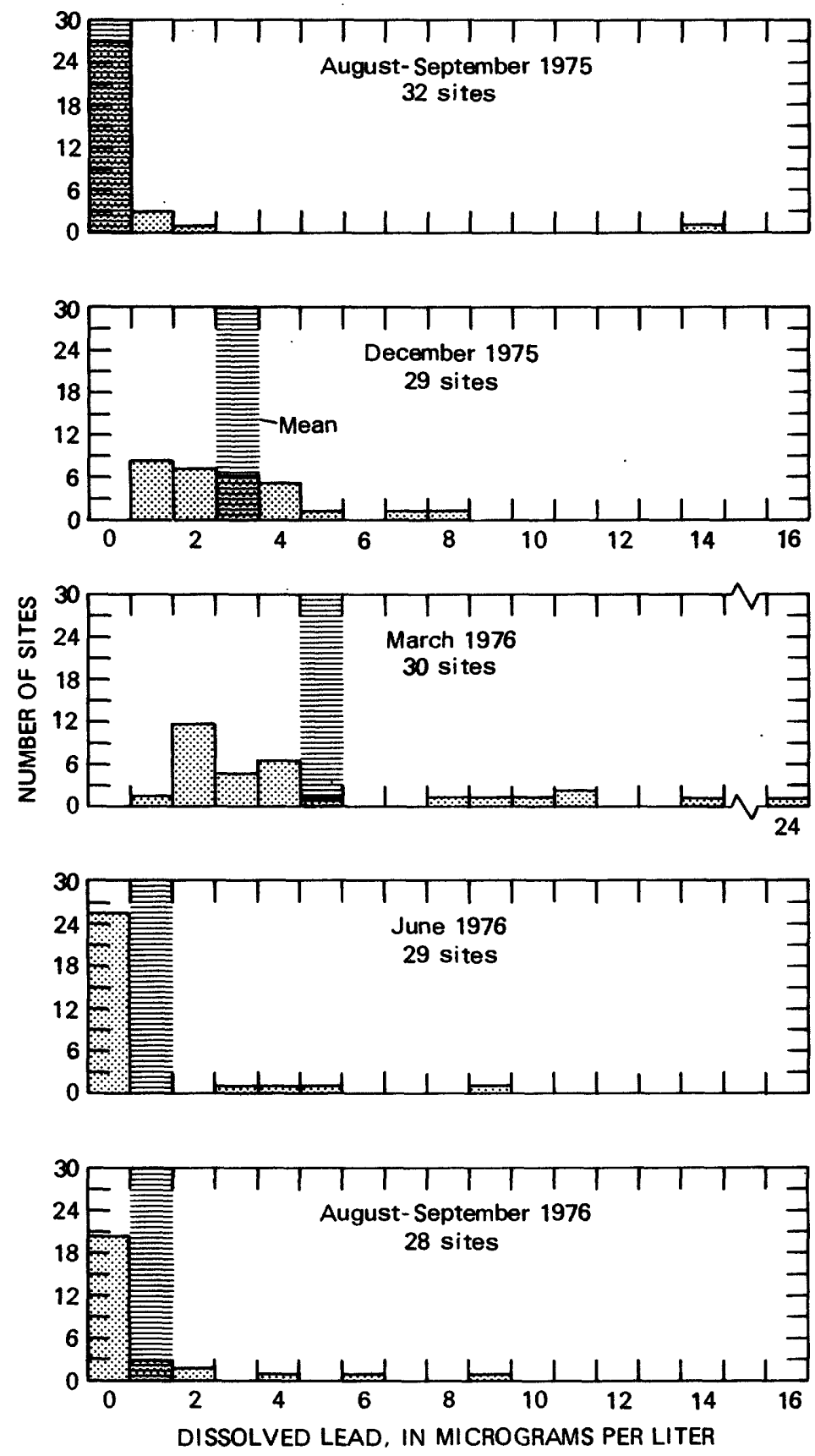

Figure 31.- Frequency distributions of dissolved lead in streams of the Yampa River basin, August-September 1975 through AugustSeptember 1976. 

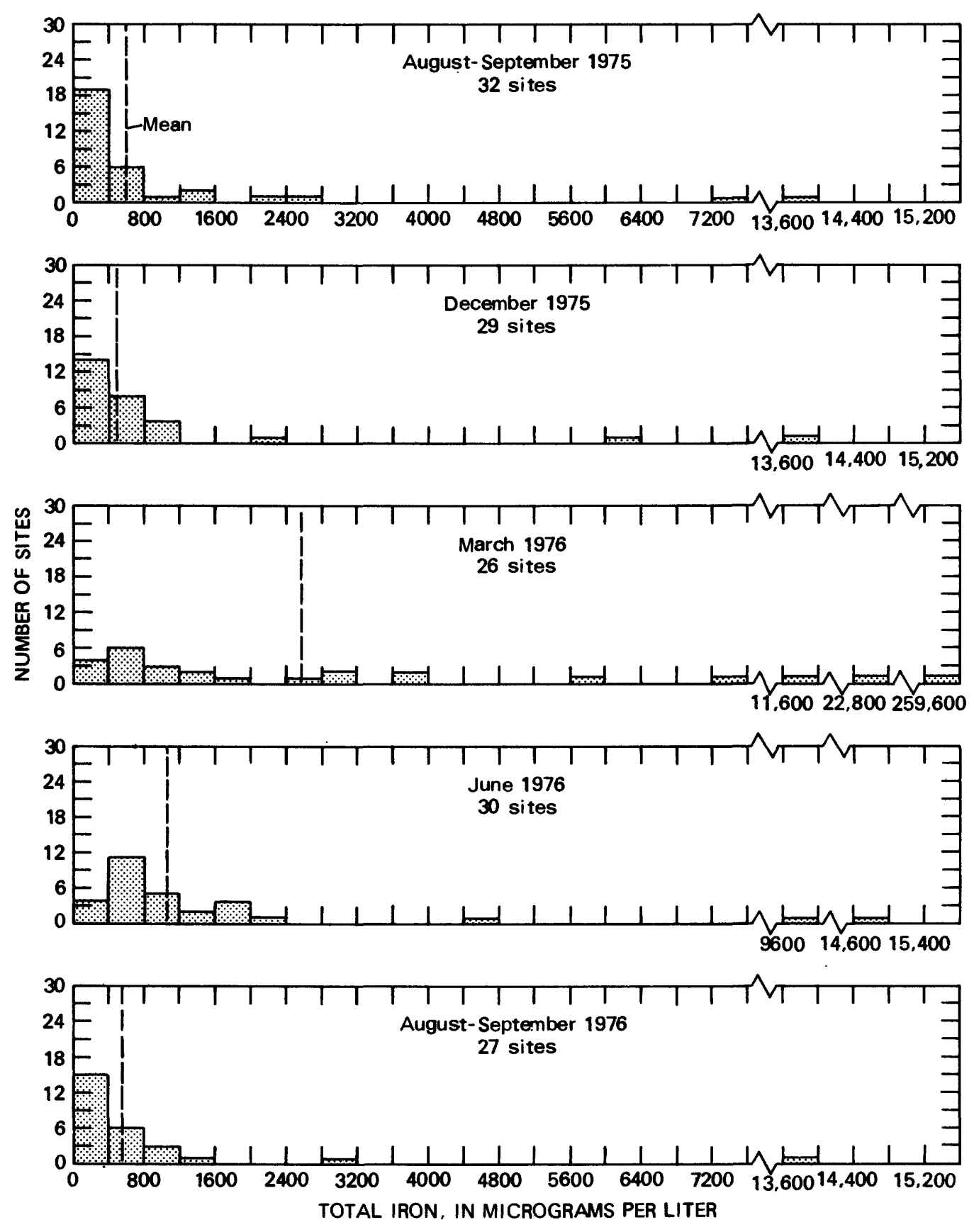

Figure 32.-Frequency distributions of total iron in streams of the Yampa River basin, August-September 1975 through AugustSeptember 1976. 

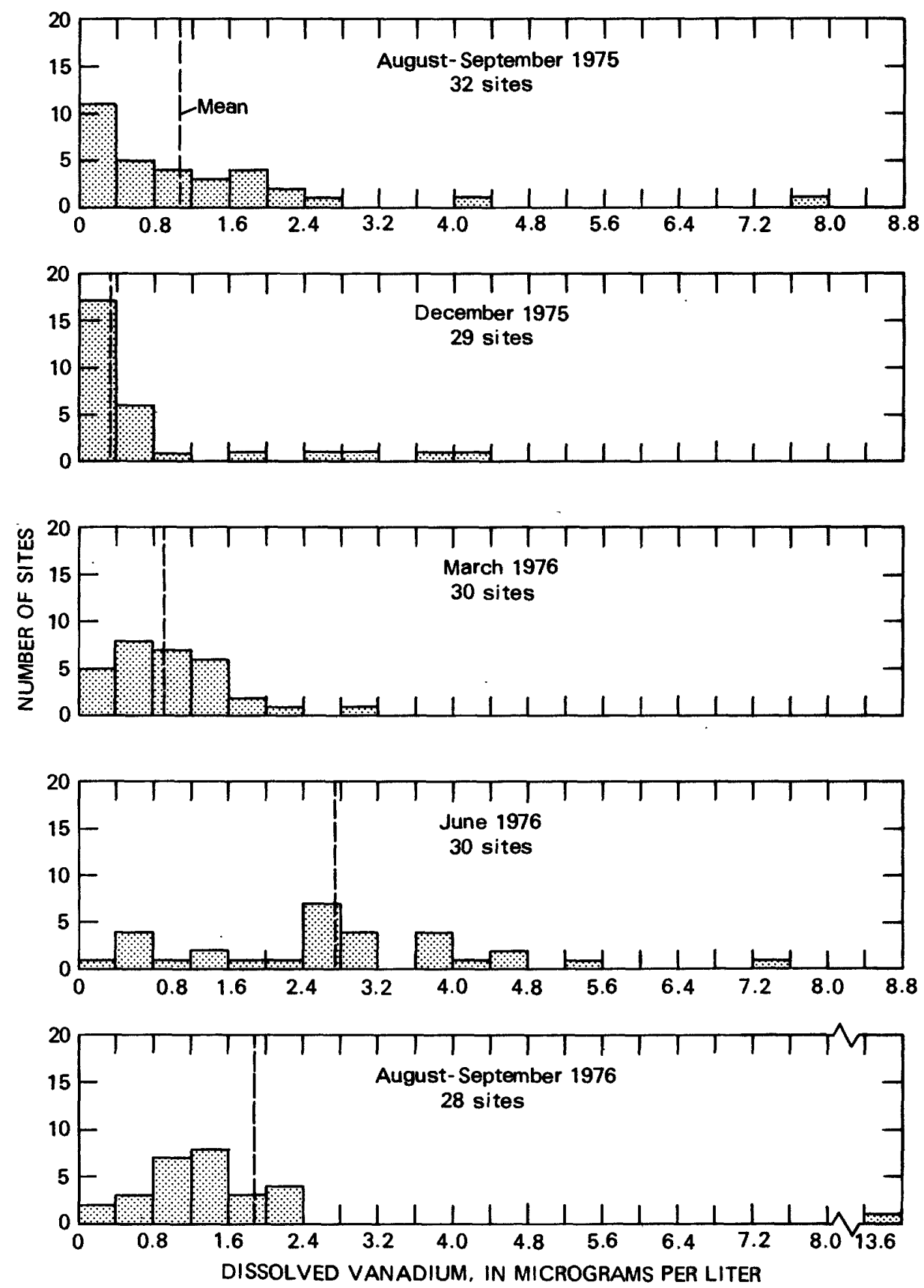

Figure 33.-- Frequency distributions of dissolved vanadium in streams of the Yampa River basin, August-September 1975 through AugustSeptember 1976. 

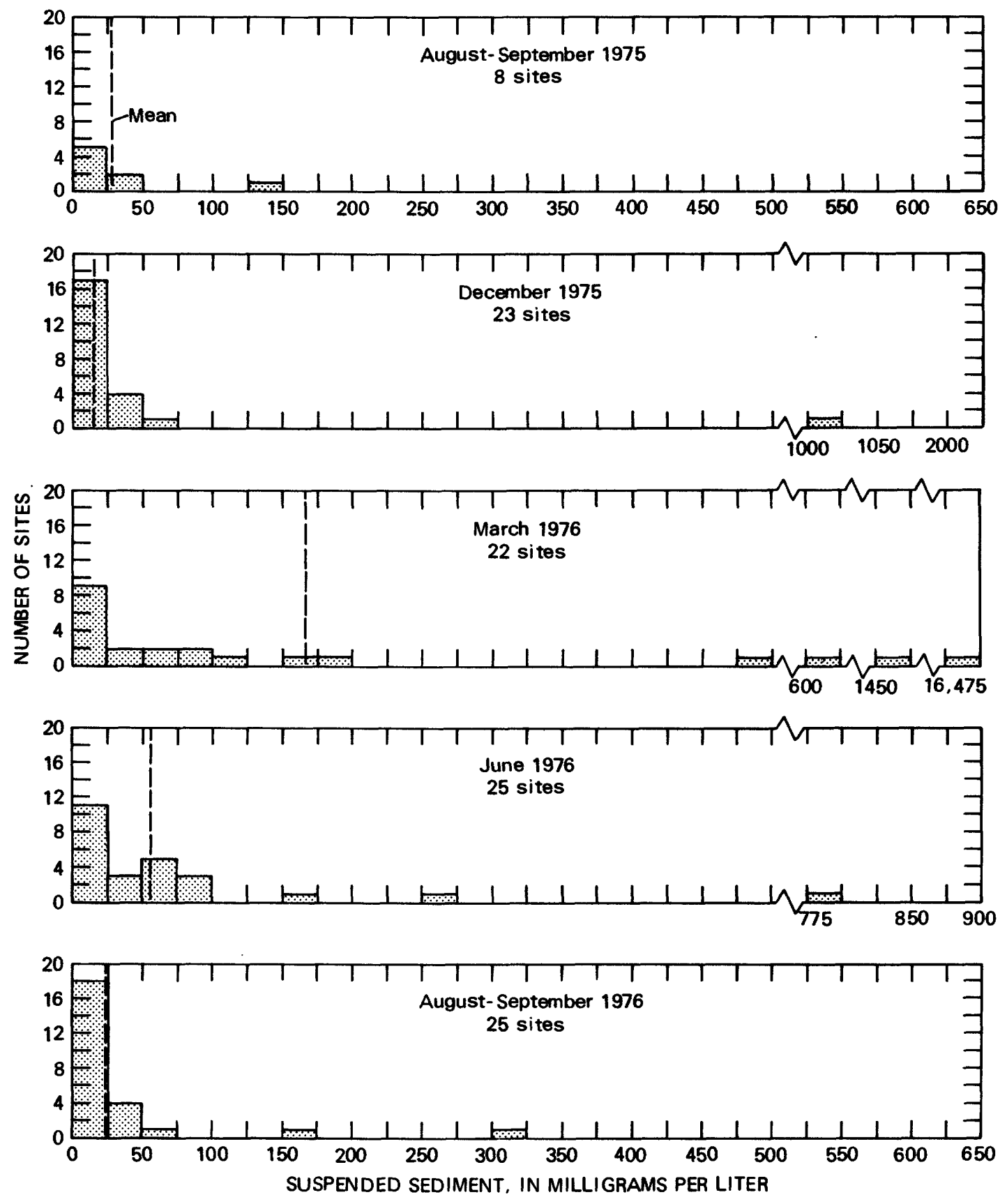

Figure 34.-- Frequency distributions of suspended sediment in streams of the Yampa River basin, August-September 1975 through AugustSeptember 1976. 

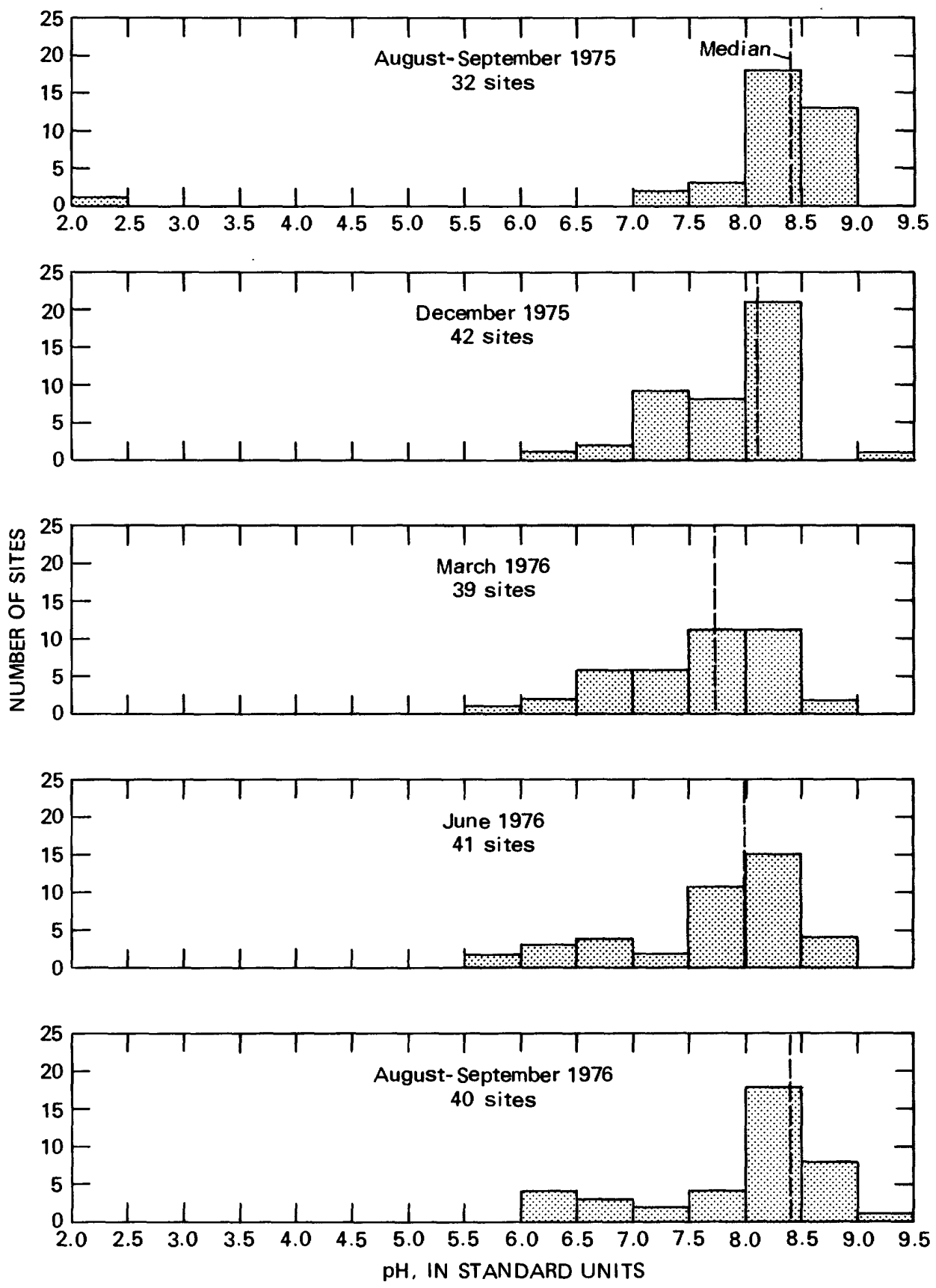

Figure 35.-- Frequency distributions of $\mathrm{pH}$ in streams of the Yampa River basin, August-September 1975 through August-September 1976. 


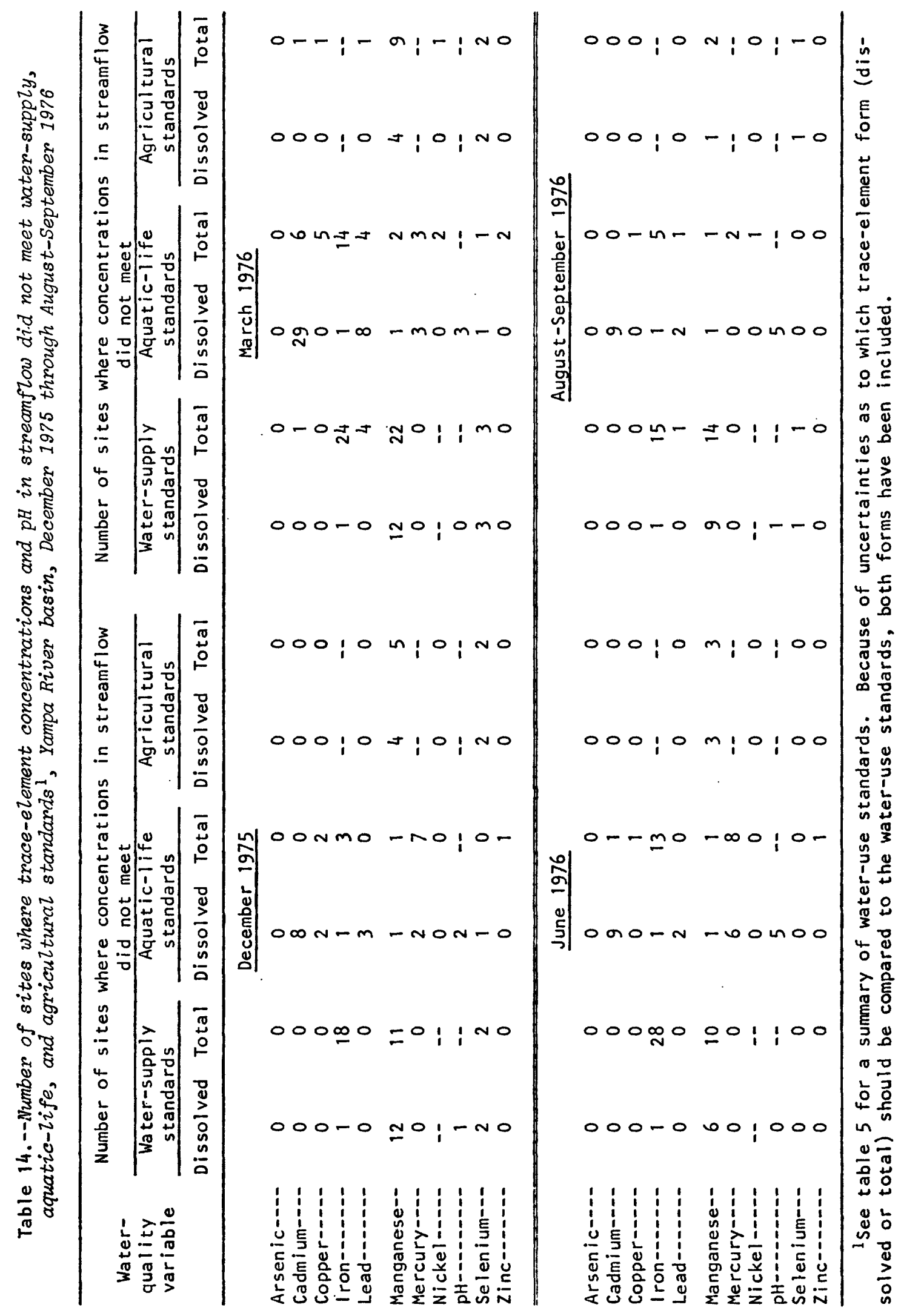


$\mathrm{pH}$.- When plotted in 0.5-unit increments, the frequency distribution for $\mathrm{pH}$ ( $\mathrm{f} \overline{\mathrm{ig}}$. 35) did not vary greatly throughout the study period. The median $\mathrm{pH}$, however, had a cyclic trend, decreasing from a maximum of 8.4 in AugustSeptember 1975 to a minimum of 7.7 in March 1976, and then increasing to 8.4 in August-September 1976. The $\mathrm{pH}$ values are discussed after reviewing the potential controlling reactions involved.

The pH of most natural waters is controlled primarily by the carbonate system (carbon dioxide, bicarbonate ions, and carbonate ions in solution). Carbon dioxide $\left(\mathrm{CO}_{2}\right)$ is dissolved either from the atmosphere or from decomposition reactions in the soil zone. The carbonic acid $\left(\mathrm{H}_{2} \mathrm{CO}_{3}\right)$ thus produced dissociates to liberate bicarbonate ion $\left(\mathrm{HCO}_{3}{ }^{-}\right)$and hydrogen ion $\left(\mathrm{H}^{+}\right)$:

$$
\mathrm{H}_{2} \mathrm{O}(\mathrm{l})+\mathrm{CO}_{2}(g)=\mathrm{H}_{2} \mathrm{CO}_{3}(a q)=\mathrm{H}_{(a q)}^{+}+\mathrm{HCO}_{3}{ }_{(a q)}{ }^{-}
$$

If an independent carbonate source, such as limestone $\left(\mathrm{CaCO}_{3}\right)$, is present, the system is said to be well buffered. Much of the liberated $\mathrm{H}^{+}$(reaction 8), instead of lowering the $\mathrm{pH}$, is used in the dissolution of the limestone:

$$
\mathrm{H}_{(a q)}^{+}+\mathrm{CaCO}_{3}(s)=\mathrm{HCO}_{3}^{-}(a q)+\mathrm{Ca}^{++}(a q)
$$

Bicarbonate produced from reaction 9 also prevents large decreases in pH by the reverse of reaction 8 .

The relatively large suspended-sediment concentrations in March (fig. 34) indicate that much of the water was surface runoff derived from snowmelt. As such, this water would be expected to have a relatively small dissolved-solids concentration and, thus, would not be well buffered. Low buffering capacity would allow for a decrease in the pH (fig. 35 ) by reaction 8. Unfortunately, the expected low dissolved-solids concentrations are not substantiated by figure $13(p .42)$, which shows the mean specific conductance to be 590 umhos for March 1976. This is just slightly less than the mean value of 610 umhos recorded for August-September 1975. On the other hand, this does not necessarily preclude lack of buffering, particularly if the dissolved solids in snowmelt runoff were derived primarily from easily dissolved noncarbonate minerals.

Another factor contributing to the smaller pH values observed in March 1976 was low water temperatures of the snowmelt runoff. Carbon dioxide is more soluble at lower temperatures, and more dissolved carbon dioxide means that more $\mathrm{H}^{+}$is liberated (reaction 8 ) to decrease the $\mathrm{pH}$.

One site that deserves special discussion is the Oak Creek drain (site $\mathrm{Y}-68$, fig. 17). As mentioned previously ( $p .48)$, this is the only site in Colorado found by Wentz (1974a) to be affected by the oxidation of pyritic materials associated with coal. Values of pH measured at this site during the quarterly sampling program ranged from 6.3 in March 1976 to 7.0 in December 1975. Because the oxidation of pyrite liberates considerable acid, pH values might be expected to be considerably less than these measured values.

$$
\mathrm{FeS}_{2}(s)+\frac{15}{4} \mathrm{O}_{2}(a q)+\frac{7}{2} \mathrm{H}_{2} \mathrm{O}_{(i)}=\mathrm{Fe}(\mathrm{OH})_{3(s)}+2 \mathrm{SO}_{4}{ }_{(a q)}+4 \mathrm{H}_{(a q)}^{+} \text {, }
$$


The most likely explanation for the larger than expected pH values at site $Y-68$ is that a carbonate source is available for combining (reaction 9, p. 89) with the $\mathrm{H}^{+}$produced by reaction 10 . Although calcium and bicarbonate were not measured at site $Y-68$ during the Yampa River basin assessment, bicarbonate concentrations of 372 to $413 \mathrm{mg} / \mathrm{L}$ and calcium concentrations of 340 to $400 \mathrm{mg} / \mathrm{L}$ were reported by Moran and Wentz (1974, p. 249) for the Oak Creek drain from October 1972 to June 1973. The $\mathrm{pH}$ range for the same period was 6.6 to 7.6. The bicarbonate and calcium concentrations reported by Moran and Wentz (1974) are greater than the maximum likely ambient concentrations of the same constituents $(360 \mathrm{mg} / \mathrm{L}$ for bicarbonate and $97 \mathrm{mg} / \mathrm{L}$ for calcium) for sites where water is not affected by sources of upstream degradation in the Yampa River basin (table 13). On an equivalent concentration basis, the calcium increase above the maximum likely ambient concentration is from 7.0 to 38 times the bicarbonate increase. Thus, much of the calcium must have been derived from noncarbonate sources.

The number of times $\mathrm{pH}$ exceeded the limits proposed by the Colorado Department of Health (1977b, table 5) for water supply and aquatic life is shown in table 14. As noted on page 57, the number of these occurrences could be different if the measurements had been made at different times of the day.

Trace elements in stream-bottom sediments.--Except for mercury, and possibly chromium, the smallest trace-element concentrations in stream-bottom sediments of the Yampa River basin were measured in samples collected in August-September 1976. Some concentrations, for example, those for arsenic (fig. 36), decreased gradually from August-September 1975 to August-September 1976. Others, such as copper (fig. 37), seem to have decreased most since March 1976. Often, as in the latter instance, the pattern is somewhat confused by the fact that a different laboratory procedure was used for reporting concentrations measured in samples collected during June 1976 . Because of the relatively large variability of the data for a given trace element during a given sampling period, and because only one seasonal cycle is represented, no attempt has been made to determine the mechanisms causing the changes.

Nutrients. - The distributions of nutrient concentrations follow the same seasonal patterns as dissolved and total trace elements. Dissolved and total Kjeldahl nitrogen, dissolved and total nitrite plus nitrate, and total phosphorus all had the largest concentrations in March 1976, with little variation among the other four sampling periods (fig. 38). Dissolved phosphorus, dissolved organic carbon ( $\mathrm{fig} .39$ ), and dissolved plus suspended organic carbon distributions changed little from August-September 1975 to AugustSeptember 1976.

The relatively large nitrogen and total phosphorus concentrations in March 1976 may have been contributed primarily by runoff from areas grazed by cattle. If so, these sources apparently contribute relatively little organic carbon. Dissolved phosphorus is readily adsorbed, and it would be expected to be retained in the soil zone. This could explain the lack of large concentrations of dissolved phosphorus in the stream during March 1976. 

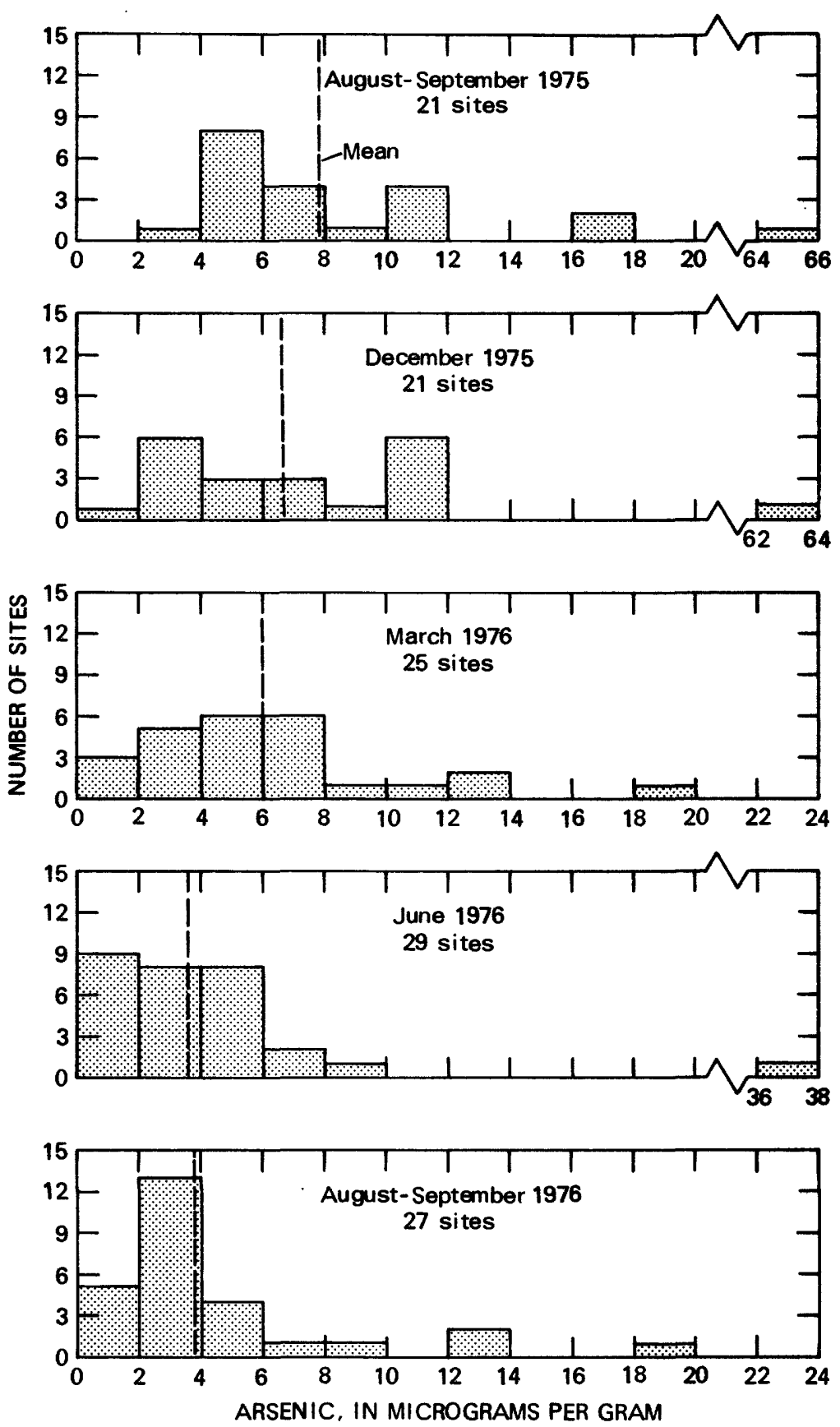

Figure 36.- Frequency distributions of arsenic in stream-bottom sediments of the Yampa River basin, August-September 1975 through August-September 1976. 

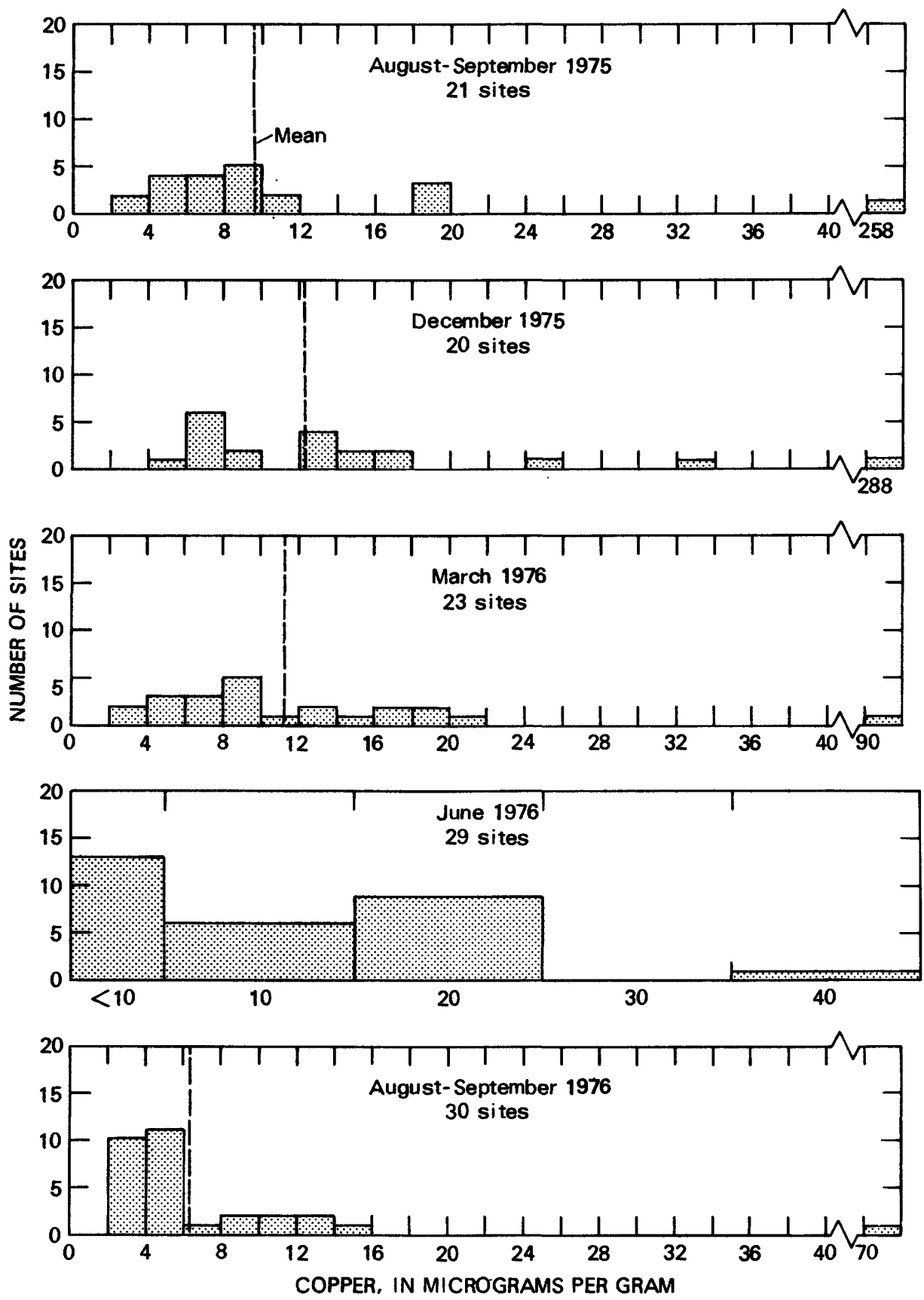

Figure 37.-- Frequency distributions of copper in stream-bottom sediments of the Yampa River basin, August-September 1975 through AugustSeptember 1976. 

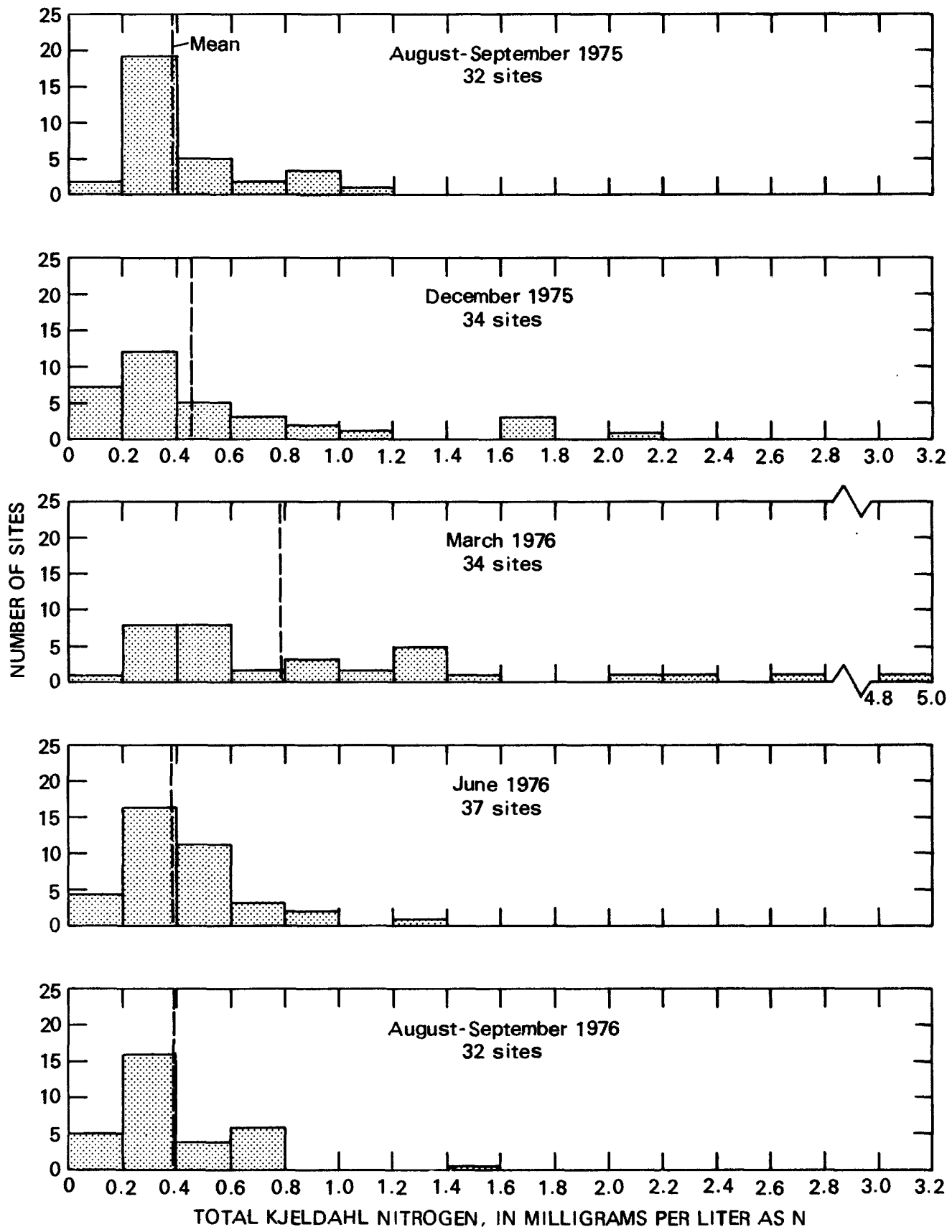

Figure 38.-- Frequency distributions of total K jeldahl nitrogen in streams of the Yampa River basin, August-September 1975 through August-September 1976. 

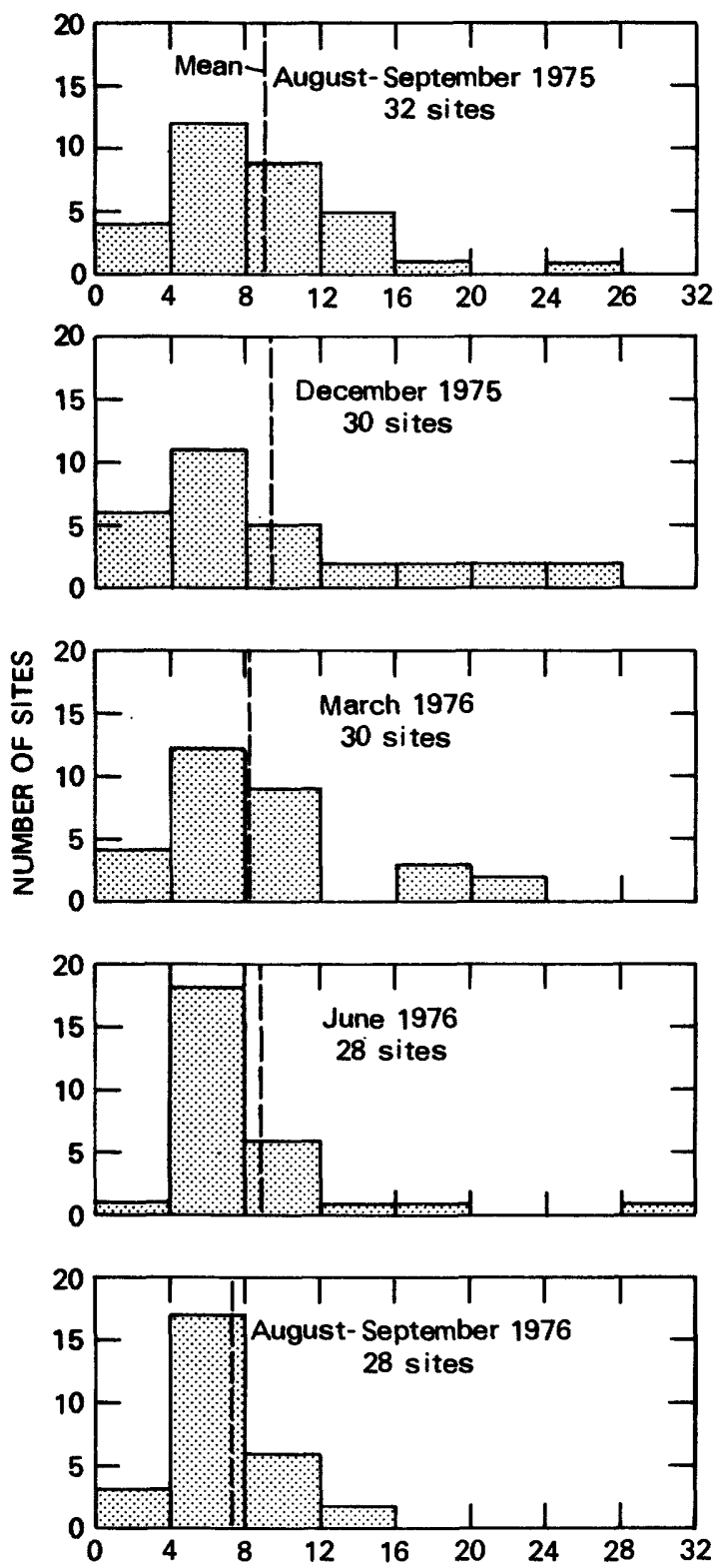

DISSOLVED ORGANIC CARBON, IN MILLIGRAMS PER LITER

Figure 39.-- Frequency distributions of dissolved organic carbon in streams of the Yampa River basin, AugustSeptember 1975 through August-September 1976. 
Dissolved oxygen.--The seasonal change in the distribution of dissolved oxygen in streams of the Yampa River basin is shown on figure 40 . The pattern is opposite the pattern of frequency distributions of water temperature (fig. 41). The dissolved-oxygen concentrations were controlled, to a large extent, by the solubility of the gas, which is greater at lower temperatures, and by reaeration (Bauer and others, 1978; 1979). The effect of photosynthesis is considerable in the late summer months, as 71 percent of the dissolved-oxygen concentrations measured during August-September 1975 and 68 percent of the concentrations measured during August-September 1976 were greater than 100-percent saturation.

From December 1975 through August-September 1976, dissolved-oxygen concentrations in water from the Oak Creek drain (site Y-68, fig. 17) ranged from 0.2 to $0.8 \mathrm{mg} / \mathrm{L}$. Ground water normally contains relatively small concentrations of dissolved oxygen because of decomposition reactions in the soil zone during recharge and because of the lack of contact of the ground water with the atmosphere. Water from the Oak Creek drain probably is further depleted of its dissolved oxygen by oxidation of pyrite (reaction 10, p. 89).

Site $Y-68$ was the only site where dissolved-oxygen concentrations in water were less than the lower limit of $5 \mathrm{mg} / \mathrm{L}$ recommended for warm-water biota (table 5) from December 1975 through August-September 1976. In addition to site $Y-68$, site $Y-48$ ( $f i g .1)$ was the only other site where dissolved oxygen in the water was less than the $6-\mathrm{mg} / \mathrm{L}$ standard recommended for coldwater biota (table 5) from December 1975 through August-September 1976. This occurred on June 9, 1976, when the measured dissolved-oxygen concentration was $5.8 \mathrm{mg} / \mathrm{L}$. Dissolved oxygen was not measured at site $\mathrm{Y}-48$ during the August-September 1976 sampling period because of lack of flow in the channel at that time. The one value shown between 5 and $6 \mathrm{mg} / \mathrm{L}$ for August-September 1976 (fig. 40) actually was measured as $6.0 \mathrm{mg} / \mathrm{L}$ and occurred at site Y-69 on August $30,1976$.

\section{Outlier.Analysis}

The outlier analysis was applied to the seasonal data in the same manner as it was applied to the reconnaissance data ( $p .43$ and 46). Results for dissolved and total trace elements and nutrients and for trace elements in stream-bottom sediments indicate seven sites with one outlier each during December 1975 through August-September 1976 and three sites with more than one outlier each during the same time period (table 15).

The results of the quarterly sampling program corroborate the results of the basinwide reconnaissance; however, the quarterly sampling program indicates additional streams draining areas where water-quality degradation may occur. With the possible exception of site $Y-62 A$, water-quality degradation may occur upstream from those sites determined to have one outlier each during December 1975 through August-September 1976 (table 15). 

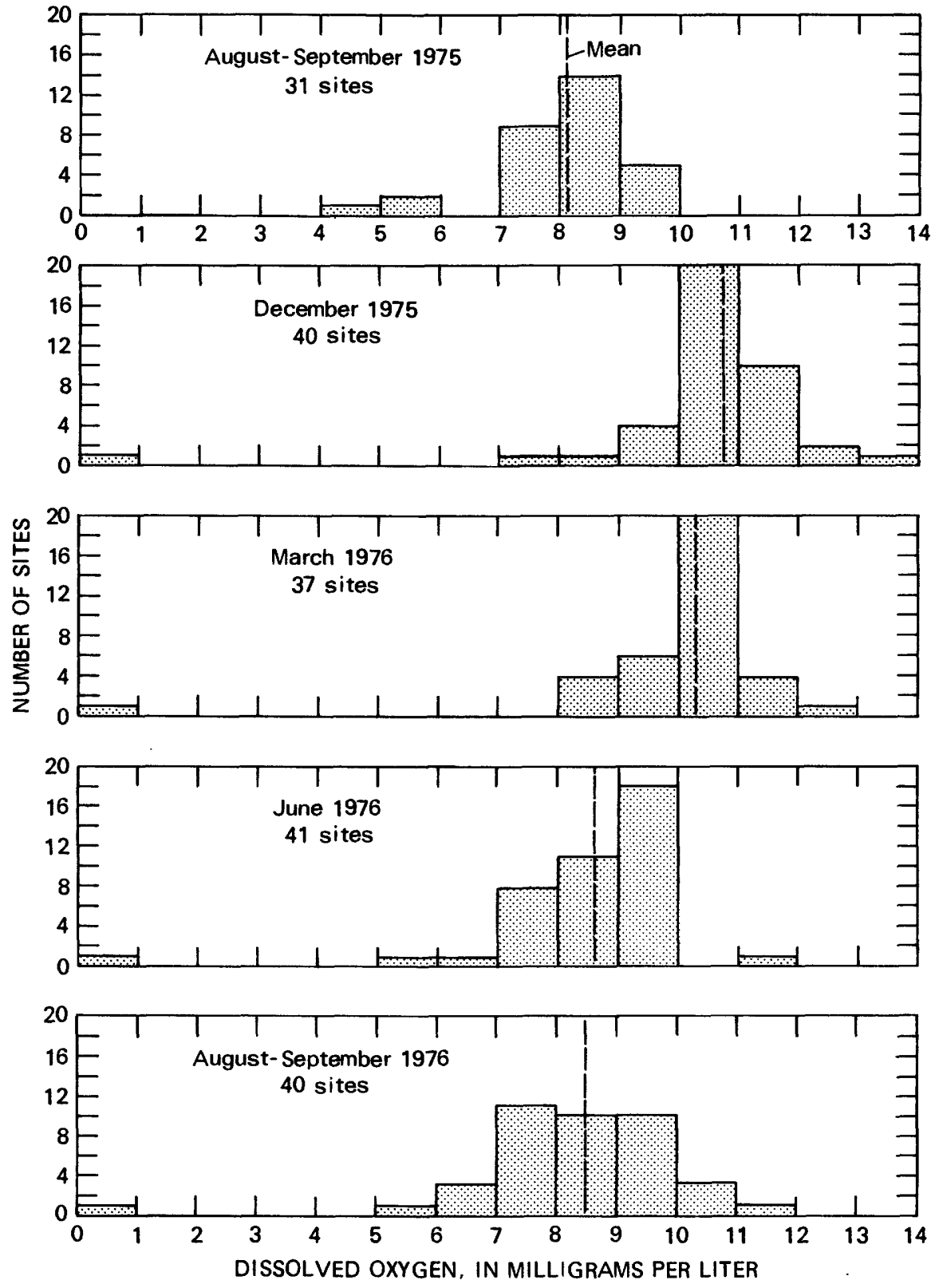

Figure 40.-- Frequency distributions of dis solved oxygen in streams of the Yampa River basin, August-September 1975 through August-September 1976. 

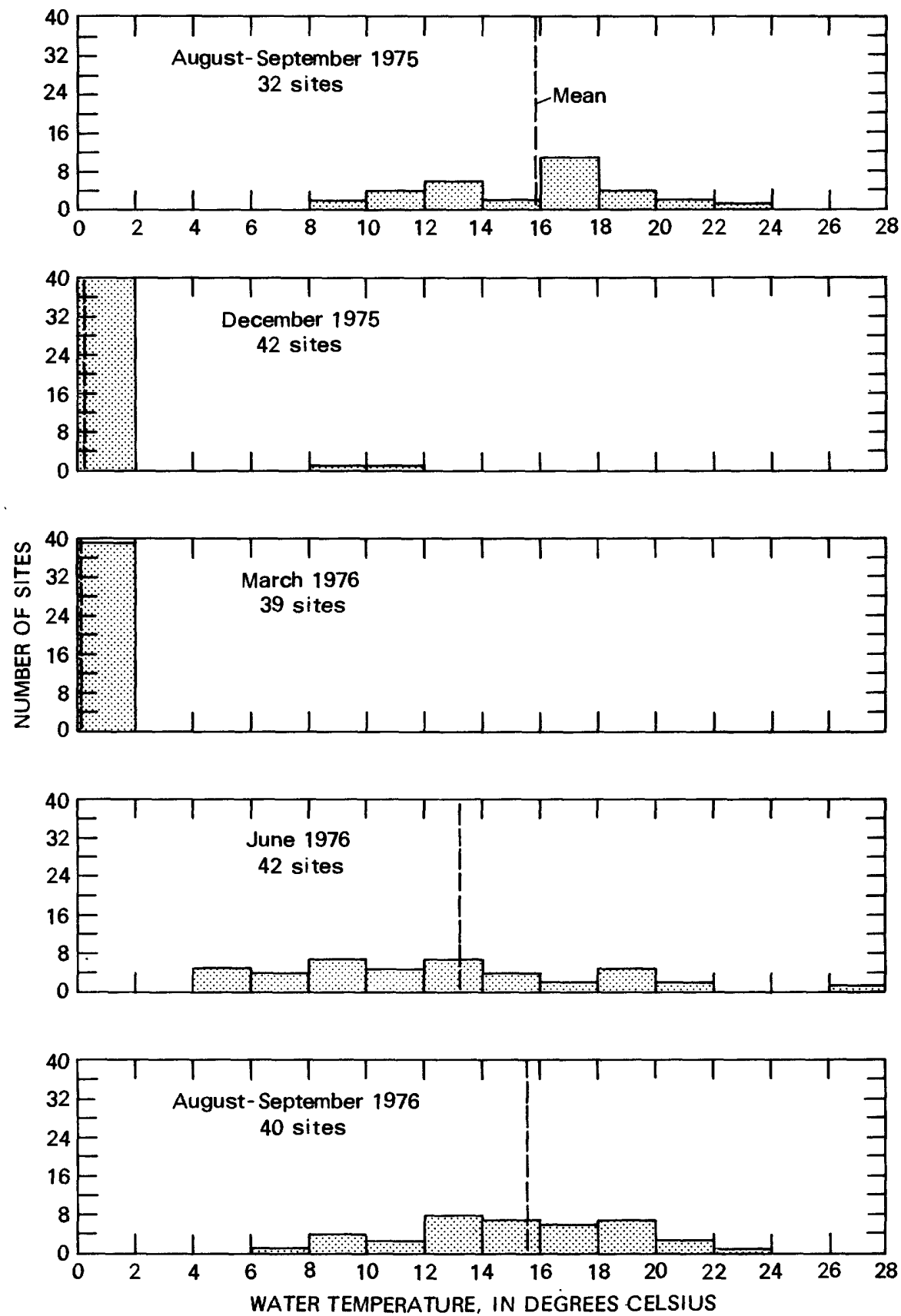

Figure 41.-- Frequency distributions of water temperature in streams of the Yampa River basin, August-September 1975 through August-September 1976. 


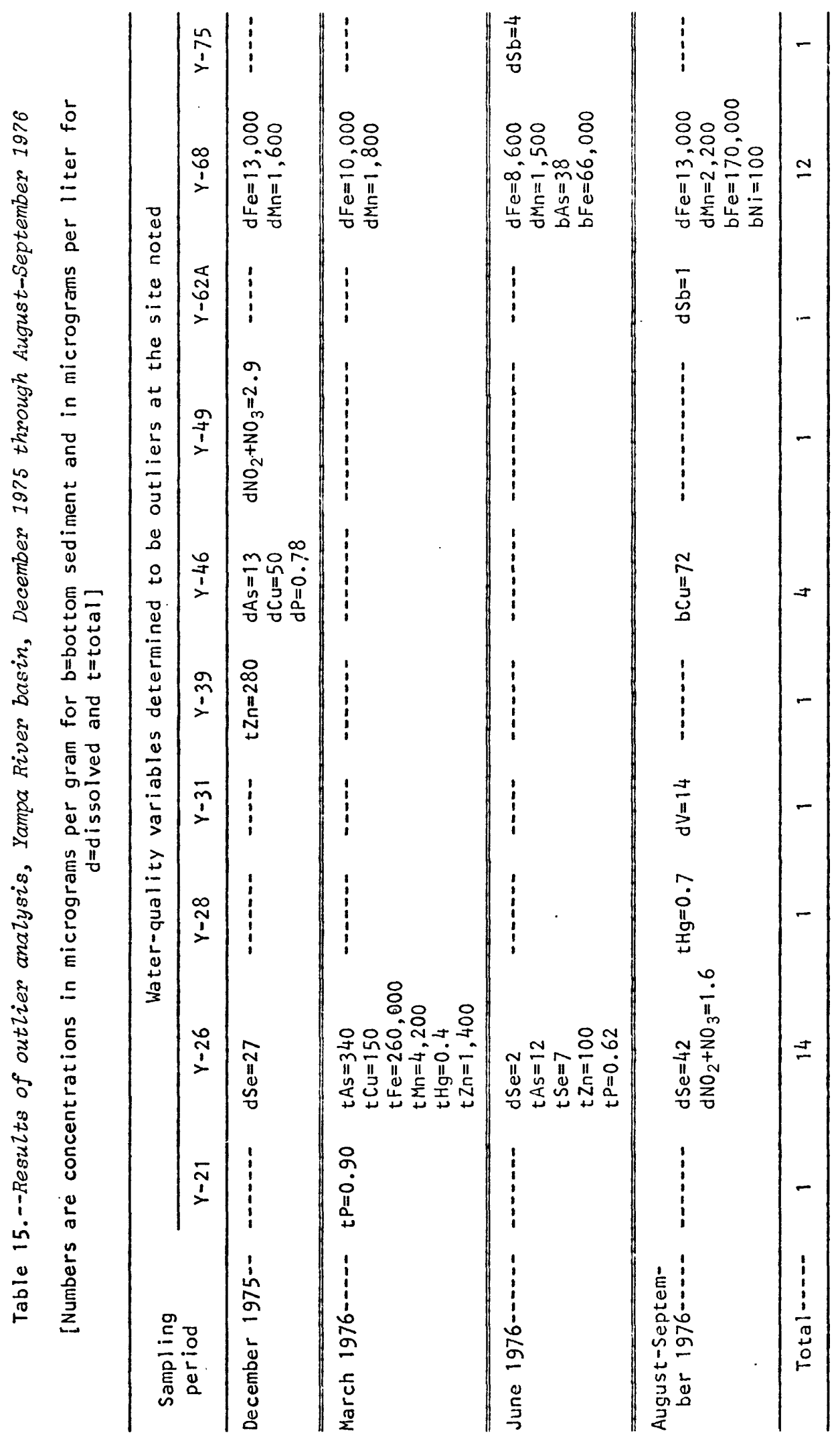


Careful consideration needs to be given to alternative water- and land-use practices in the watersheds upstream from these sites. The three sites determined to have more than one outlier each (sites $Y-26, Y-46$, and $Y-68$, fig. 17) are the three primary sites where upstream water-quality degradation is indicated based on data collected during the basinwide reconnaissance. However, water quality at site $Y-46$ appears to have improved since December 1975 (table 15); this improvement probably results from the implementation on April 30, 1976, of a closed evaporation-pond system for disposal of all powerplant wastewater (Leon Brestel, oral commun., December 1977). The stream at site $\mathrm{Y}-54$ ( $\mathrm{fig}$. 17), where upstream water-quality degradation was indicated during the basinwide reconnaissance ( $p .48$ and 67 ), was not sampled during the quarterly sampling program, as it was being sampled as part of another ongoing U.S. Geological Survey study (table 1). Site Y-21, where water was found to contain outlier concentrations of sodium and chloride from suspected irrigation return flow during the basinwide reconnaissance (p. 63), was one of the sites determined to have one outlier during the quarterly sampling program (table 15).

\section{Changes in Ambient Stream Quality}

Because stream quality in the Yampa River basin changes with season, maximum likely ambient concentrations of selected chemical constituents have been calculated for each of the four quarterly sampling periods from December 1975 to August-September 1976. These concentrations are presented in table 16; they have been calculated, following the procedure given on page 75 , from data at all quarterly sites except $Y-26, Y-46$, and $Y-68$ (fig. 17). Again, the calculated concentrations are applicable only to the respective data-collection periods. Considerable randomness is inherent in the sample values used to determine these limits, although inclusion of the standard deviation in the limit attempts to take this into account. The values in table 16 provide an approximation of the potential seasonal variability of maximum concentrations to be expected in streams of the Yampa River basin prior to extensive coal-resource development.

\section{Toxic Organic and Radiochemical Constituents}

Total concentrations of toxic organic and radiochemical constituents were analyzed in water collected from two sites on the Little Snake River (sites $Y-1$ and $Y-8$, fig. 1) and from five sites on the Yampa River (sites $Y-17, Y-39, \quad Y-47, Y-64$, and $Y-72$, fig. 1) during June 1976 when streamflows and sediment concentrations were relatively large as a result of snowmelt runoff. None of the following 24 toxic organic chemicals was found in detectable concentrations: Aldrin, Chlordane, DDD, DDE, DDT, Diazinon, Dieldrin, Endrin, Ethyl Parathion, Ethyl Trithion, Ethion, Heptachlor Epoxide, Heptachlor, Lindane, Malathion, Methyl Parathion, Methyl Trithion, PCB (polychlorinated byphenyl), PCN (polychlorinated naphthalene), Silvex, Toxaphene, 2,4-D, 2,4-DP, and 2,4,5-T. 
Table 16.--Seasonal changes in maximun likely ambient concentrations of chemical constituents in streans of the Yampa River basin, December 1975 to August-September 1976

\begin{tabular}{|c|c|c|c|c|}
\hline \multirow{2}{*}{ Constituent } & \multicolumn{4}{|c|}{ Concentration ${ }^{1}(\bar{x}+2 s)$} \\
\hline & $\begin{array}{l}\text { December } \\
1975\end{array}$ & March 1976 & June 1976 & $\begin{array}{c}\text { August- } \\
\text { September } 1976\end{array}$ \\
\hline $\begin{array}{l}\text { Specific conductance, micromhos per } \\
\text { centimeter at } 25^{\circ} \mathrm{C}-\end{array}$ & 1,200 & 2,100 & 970 & 1,300 \\
\hline \multicolumn{5}{|c|}{ Constituent, in milligrams per liter } \\
\hline $\begin{array}{l}\text { Dissolved organic carbon- } \\
\text { Dissolved plus suspended organic car- } \\
\text { bon- } \\
\text { Dissolved Kjeldahi nitrogen, as } \mathrm{N} \\
\text { Total Kjeldahl nitrogen, as } \mathrm{N}\end{array}$ & $\begin{array}{r}21 \\
24 \\
1.0 \\
1.2\end{array}$ & $\begin{array}{l}19 \\
26 \\
1.4 \\
2.0\end{array}$ & $\begin{array}{r}20 \\
.63 \\
.80\end{array}$ & $\begin{array}{r}14 \\
14 \\
.69 \\
.98\end{array}$ \\
\hline $\begin{array}{l}\text { Dissolved nitrite plus nitrate, as } \mathrm{N}- \\
\text { Total nitrite plus nitrate. as } \mathrm{N} \\
\text { Dissolved phosphorus, as P... } \\
\text { Total phosphorus, as P }\end{array}$ & $\begin{array}{l}1.2 \\
1.2 \\
.15 \\
.18\end{array}$ & $\begin{array}{l}6.0 \\
5.9 \\
.16 \\
.45\end{array}$ & $\begin{array}{l}.095 \\
.099 \\
.096 \\
.20\end{array}$ & $\begin{array}{l}.29 \\
.31 \\
.25 \\
.32\end{array}$ \\
\hline
\end{tabular}

Constituent, in micrograms per liter

Dissolved antimony-1.--

Total antimony-1.-

Dissolved arsenic--

Total arsenic--

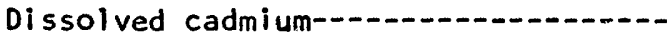

Total cadmium--..-

Dissolved cobalt--...-

Total cobalt--

Dissolved copper--.-.-.-

Total copper-

Dissolved iron--...-.

Total iron--

Dissolved lead--...-.

Total lead--.........

Dissolved manganese--..-

Total manganese-...

Dissolved mercury--...-

Total mercury--

Dissolved nickel-_..._.

Total nickel-

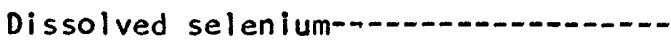

Total selenium--

Dissolved vanadium--

Dissolved zinc-.......

Total zinc-.......

$\begin{array}{cc}2.4 & .0 \\ 2.4 & 2.9 \\ 1.2 & 2.7 \\ 1.4 & 10 \\ 1.7 & 4.9\end{array}$

(2)

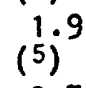

(5)

9.7

220

1,400

6.4

(8)

320

350

.062

.11

4.3

(6)

(3)

1.7

(6)

4.1

(7)

.0

2.9

2.7

4.9

210

12,000

(9)

200

460

\section{5 \\ 2.4 \\ 1.0}

18

130
.11

.046

$\left(^{3}\right)^{3}$

15

19

1.9

18

69
1.8

.87

1.6

2.8

1.4

(4)

1.3

(6)

4.6

(7)

170

2,900

5.1

(8)

150

220

.16

.22

4.2

(6)

.0
.84
6.0
35

.44

.0

2.1

2.7

1.6

(2)

2.1

(6)

2.2

(7)

150 1,900

5.5

(8)

130

180

.00

2.31

(6)

2.1

2.1

7.0

10

16 
Table 16.--Seasonal changes in maximum likely ambient concentrations of chemical constituents in streams of the Yampa River basin, December 1975 to August-September 1976--Continued

\begin{tabular}{|c|c|c|c|c|c|}
\hline \multirow{2}{*}{\multicolumn{2}{|c|}{ Constituent }} & \multicolumn{4}{|c|}{ Concentration ${ }^{1}(\bar{x}+2 s)$} \\
\hline & & $\begin{array}{c}\text { December } \\
1975 \\
\end{array}$ & March 1976 & June 1976 & $\begin{array}{c}\text { August- } \\
\text { September } 1976\end{array}$ \\
\hline \multicolumn{6}{|c|}{ Constituent, in micrograms per gram } \\
\hline $\begin{array}{l}\text { Bottom } \\
\text { Bottom } \\
\text { Bottom } \\
\text { Bottom } \\
\text { Bottom }\end{array}$ & $\begin{array}{l}\text { ant imony } \\
\text { arsen ic } \\
\text { chrom i um } \\
\text { copper } \\
\text { i ron }\end{array}$ & $\begin{array}{l}3.1 \\
14 \\
5.4 \\
22 \\
56,000\end{array}$ & $\begin{array}{r}3.8 \\
9.3 \\
16 \\
22 \\
22,000\end{array}$ & $\begin{array}{r}2.2 \\
7.7 \\
(7)^{7} \\
\left({ }^{7}\right) \\
21,000\end{array}$ & $\begin{array}{r}0.0 \\
11 \\
12 \\
13 \\
9,900\end{array}$ \\
\hline $\begin{array}{l}\text { Bot tom } \\
\text { Bottom } \\
\text { Bot tom } \\
\text { Bottom } \\
\text { Bottom }\end{array}$ & $\begin{array}{l}\text { lead } \\
\text { mercury } \\
\text { nickel } \\
\text { selenium } \\
\text { silver }\end{array}$ & $28^{29} .076$ & ${ }_{45}^{20} .49$ & $\left(^{(7)} j^{26}\right.$ & ${ }^{29} .24$ \\
\hline
\end{tabular}

IIn a few cases, the dissolved concentration is greater than the total concentration for the same constituent during the same sampling period. This occurs because the value of $s$ for the dissolved constituent is greater than the value of $s$ for the total constituent.

${ }^{2}$ All values were less than 10 micrograms per liter.

${ }^{3} \mathrm{All}$ but three values were less than 10 micrograms per liter.

${ }^{4} \mathrm{All}$ but one value were less than 10 micrograms per liter.

${ }^{5} \mathrm{All}$ but one value were less than 50 micrograms per liter.

${ }^{6} \mathrm{All}$ values were less than 50 micrograms per liter.

${ }^{7}$ The variables $\bar{x}$ and $s$ could not be calculated because too many data values were reported as less than a given number.

${ }^{8} \mathrm{All}$ values were less than 100 micrograms per liter.

${ }^{9} \mathrm{All}$ but two values were less than 100 micrograms per liter. 
The radiochemical constituents analyzed included dissolved and suspended gross alpha and gross beta radioactivity and dissolved potassium-40. All dissolved radioactivity values were relatively small and constant. Dissolved gross alpha concentrations as natural uranium ranged from less than 0.6 to $1.7 \mu \mathrm{g} / \mathrm{L}$, with one value reported as less than $4.3 \mu \mathrm{g} / \mathrm{L}$. Dissolved gross beta activity as cesium-137 ranged from 1.2 to $4.1 \mathrm{pCi} / \mathrm{L}$ (picocuries per liter). Dissolved potassium-40 activity ranged from 0.2 to $2.0 \mathrm{pCi} / \mathrm{L}$.

Radioactivity values in the suspended phase had definite areal patterns. Suspended gross beta activity as cesium-137 in the Yampa River increased consistently from $0.9 \mathrm{pCi} / \mathrm{L}$ at site $Y-72$ to $3.4 \mathrm{pCi} / \mathrm{L}$ at site $Y-17$ (fig. 1). Suspended gross alpha concentrations as natural uranium increased from $0.9 \mu \mathrm{g} / \mathrm{L}$ at site $Y-72$ to $7.9 \mu \mathrm{g} / \mathrm{L}$ at site $Y-17$, but most of the increase occurred between site $Y-17$ and the next sampled upstream site (site $Y-39$ ), where a gross alpha concentration of $2.2 \mu \mathrm{g} / \mathrm{L}$ was determined. Between sites $Y-8$ and $Y-1$ on the Little Snake River, suspended gross alpha concentrations increased 7.9 times and gross beta activity increased 5.9 times. Actual radioactivity levels at site $Y-1$ were $15 \mu \mathrm{g} / \mathrm{L}$ as natural uranium for gross alpha concentration and $8.3 \mathrm{pCi} / \mathrm{L}$ as cesium-137 for gross beta activity. Thus, it appears, at least in June, that most of the radioactivity was transported in the suspended phase and is derived from natural, easily eroded materials in the downstream parts of each subbasin.

Comparison of measured radioactivity levels to water-quality standards (table 5) has not been attempted because of differences between the way the standards have been promulgated by the Colorado Department of Health (1977b) and in the way the results are reported by the U.S. Geological Survey laboratory.

\section{Effects of Coal Mining on Stream Quality}

The effects of specific coal mines on stream quality can be evaluated using several approaches: (1) By measuring stream quality at a site downstream from a mining operation for an extended period of time, beginning prior to any mining activity, extending through the construction and mining phases, and continuing after mining has ceased; (2) by comparing stream quality at several sites downstream from operating mines to comparable data collected from streams draining undeveloped basins that are geologically and hydrologically similar; and (3) by comparing stream quality downstream from an operating mine to stream quality upstream from the same operation.

Because of the relative shortness of the data-collection period supported by this study, realization of the first alternative--long-term data collection at a downstream site before, during, and after mining--has not been possible, nor intended. What has been intended and presented in this report, however, is a regional characterization of the stream quality of the Yampa River basin at a point in time that is relatively early in the development of the coal resources of the basin. This characterization provides a set of data with which to compare any stream-quality data collected during later periods in the coal-development process. 
The second alternative for evaluating the effects of coal mining on stream quality requires stream-quality data from mined and unmined basins having similar geologic and hydrologic characteristics. The minimum altitudes for watersheds in the Yampa River basin containing operating coal mines during the data-collection period (August 1975 to September 1976) range only from 6,550 to $6,700 \mathrm{ft}(2,000$ to $2,040 \mathrm{~m})$. However, maximum altitudes in the same areas range from 8,300 to more than $12,000 \mathrm{ft}(2,500$ to $3,700 \mathrm{~m})$. Thus, the hydrologic characteristics of these watersheds can be considerably different. In addition, four major geologic units are represented in these areas. They are the Lewis Shale, the Williams Fork and lles Formations of the Mesaverde Group, and the Mancos Shale, all of Late Cretaceous age. The Williams Fork and lles Formations contain the major coal beds in the Yampa River basin. Ground-water quality from these geologic units varies widely (Brogden and Giles, 1977), as shown in the following table:

\begin{tabular}{|c|c|c|}
\hline Geologic unit & $\begin{array}{l}\text { Number of } \\
\text { samples }\end{array}$ & $\begin{array}{l}\text { Range of specific conductance }{ }^{l} \\
\text { (micromhos per centimeter at } 25^{\circ} \mathrm{C} \text { ) }\end{array}$ \\
\hline Lewis Shale--n- & 8 & $455-6,000$ \\
\hline Mesaverde Group------ & 33 & $420-2,100$ \\
\hline Mancos Shale----n---- & 5 & $630-3,800$ \\
\hline
\end{tabular}

IFrom Brogden and Giles (1977).

Thus, the criteria requiring similar hydrologic and geologic conditions could not be met, and the second alternative was not implemented.

Comparison of stream quality upstream and downstream from the same coal mine (the third alternative for evaluating the effect of mining on stream quality) is best approached using a mass-balance budget. All water contributed to and exported from the mined area must be known, as must the concentration of the chemical constituent of interest in these contributions and exports. If the chemical constituent reacts with the environment, the mechanism of the reaction must be known, and the amount of reactivity must be predictable. Because this usually is not possible, a nonreactive component, typically assumed to be dissolved solids, often is considered. The load of chemical constituent contributed to the mined area is measured and added to that load predicted to be gained from the mined area assuming no effect resulting from the mining. The sum is subtracted from the measured load exported from the mined area, and any difference is attributed to the mining operation. 
McWhorter and Rowe (1976) have used a mass-balance model to study the effects of the Edna Mine (fig. 17) on the water quality of Trout Creek. They found that although the mined areas represented only 14 percent of the watershed, these areas contributed 52 percent of the dissolved solids leaving the watershed in 1975. The discharge-weighted dissolved-solids concentration contributed by the mined areas was $2,860 \mathrm{mg} / \mathrm{L}$ or nearly $2,500 \mathrm{mg} / \mathrm{L}$ greater than the dissolved-solids concentration contributed by undisturbed land in the watershed. Most of the dissolved solids were contributed by ground water (including subsurface flow) and consisted principally of calcium, magnesium, bicarbonate, and sulfate ions. The model predicted dissolved-solids concentrations to within 20 percent. Sufficient information was not collected as part of the current study to apply the above mass-balance model in other parts of the Yampa River basin. However, data currently (1979) being collected as part of other U.S. Geological Survey studies in the basin (table 1) may be amenable to this type of analysis.

\section{SUMMARY}

Variations in ambient stream quality of the Yampa River basin have been documented by application of a variety of statistical techniques to historic and recently collected data. All major components of stream quality have been investigated except for sediment transport, which is the subject of a separate basin-assessment report (Andrews, 1978).

Long-term historic records of water temperature, specific conductance, and major inorganic constituents are available since 1951 for sites near the mouths of the Yampa River and the Little Snake River subbasins. Analyses of these data showed no time trends for water temperature at either site or for specific conductance at the Little Snake River site. However, a 14-percent increase in specific conductance was noted for the Yampa River. This increase is attributed to increased agricultural and municipal use of surface water.

Short-term, intermittent water-temperature data for 34 sites in the basin from 1960 to 1975 were used to develop a regional regression relationship between annual harmonic-mean temperature and altitude of the stream sites. This relationship can be used to estimate annual harmonic-mean temperature at sites with little or no previous data and which have minimal development upstream from the sites. Similar data on specific conductance and major inorganic constituents collected from 34 sites from 1944 to 1958 were used to develop regional regression relationships that allow the various major inorganic constituents to be estimated from measurements of specific conductance. These regional regression relationships were similar to sitespecific relationships developed from the long-term data for the Yampa and the Little Snake Rivers. 
To complement information obtained from historic stream-quality data and to determine current ambient stream quality during low flow, a basinwide reconnaissance of 82 sites was conducted during August-September 1975. Quarterly samples at 32 of the reconnaissance sites and 10 additional sites in or near Routt National Forest were collected from December 1975 through August-September 1976 to determine seasonal variations in stream quality.

Regional regression relationships between specific conductance and major inorganic constituents as determined from 26 of the 82 reconnaissance sites were similar to the regional and site-specific regression relationships based on historic data. An outlier analysis of regional frequency distributions of dissolved and total trace-element and nutrient concentrations in water and trace-element concentrations in stream-bottom sediments indicated degraded water quality upstream from three sites in the basin. One site is affected by underground drainage, probably from pyritic materials that are associated with coal. A second site is located just downstream from a powerplant that was discharging cooling-tower blowdown water at or near the time of sampling. The watershed upstream from the third site contains a natural gas field, although no actual drainage to the stream from the gas field has been noted.

Comparison of ambient stream quality in the Yampa River basin with proposed. Colorado water-use standards for water supply, aquatic life, and agriculture showed that dissolved and total iron and manganese most frequently exceeded the standards. Only 3 of 81 dissolved-oxygen concentrations were less than the minimum limit for cold-water biota in August-September 1975, and only in the underground coal-mine drainage was the dissolved-oxygen concentration less than the limit during all seasons. Dissolved-oxygen concentrations are controlled primarily by oxygen solubility and reaeration, except during late summer when photosynthesis plays an important role. The $\mathrm{pH}$ at the site downstream from the powerplant was 2.1 in August-September 1975 and was the only abnormally low value to be recorded throughout the study.

Seasonally, many dissolved and total trace-element and nutrient concentrations exhibited maximums during March 1976. Increased concentrations of suspended forms may be associated with higher suspended-sediment concentrations than at other times of the year, and increased concentrations of dissolved forms might be explained by lower $\mathrm{pH}$ values than at other times of the year. Seasonal variations in specific conductance are controlled primarily by stream discharge.

Maximum likely ambient concentrations of selected chemical constituents in streams of the Yampa River basin were calculated from the low-flow (reconnaissance) and seasonal (quarterly) data. Comparisons with these values will assist in delineating areas of water-quality degradation and will help assess changes in stream quality that may occur as coal-resource and associated economic development proceed in the basin. 
Ames, E. L., 1977, Aquatic insects of two western slope rivers, Colorado: Fort Collins, Colorado State University, Department of ZoologyEntomology, unpublished M.S. thesis, $95 \mathrm{p}$.

Andrews, E. D., 1977, Relation between sediment-water discharge and channel size, Yampa River basin, Colorado and Wyoming [abs.]: American Geophysical Union Transactions, EOS, v. 58, no. 12, Paper H-51, December 1977 , p. 1137 .

1978, Present and potential sediment yields in the Yampa River basin, Colorado and Wyoming: U.S. Geological Survey Water-Resources Investigations 78-105, 33 p.; available from U.S. Department of Commerce, National Technical Information Service, Springfield, VA 22161, as Report PB-292 677.

Bauer, D. P., Steele, T. D., and Anderson, R. D., 1978, Analysis of wasteload assimilative capacity of the Yampa River, Steamboat Springs to Hayden, Routt County, Colorado: U.S. Geological Survey Water-Resources Investigations 77-119, $69^{\circ} \mathrm{p}$.; available from U.S. Department of Commerce, National Technical Information Service, Springfield, VA 22161, as Report PB-278 051.

Bauer, D. P., Rathbun, R. E., and Lowham, H. W., 1979, Traveltime, unitconcentration, longitudinal-dispersion, and reaeration characteristics of upstream reaches of the Yampa and Little Snake Rivers, Colorado and Wyoming: U.S. Geological Survey Water-Resources Investigations 78-122, 66 p.; available from U.S. Department of Commerce, National Technical Information Service, Springfield, VA 22161, as Report PB-80 129521.

Blackman, W. C., Jr., Rouse, J. V., Schillinger, G. R., and Shafer, W. H., Jr., 1973, Mineral pollution in the Colorado River basin: Water Pollution Control Federation Journal, v. 45, p. 1517-1557.

Brogden, R. E., and Giles, T. F., 1977, Reconnaissance of ground-water resources in a part of the Yampa River basin between Craig and Steamboat Springs, Moffat and Routt Counties, Colorado: U.S. Geological Survey Water-Resources Investigations 77-4, 1 map.

Brown, Eugene, Skougstad, M. W., and Fishman, M. J., 1970, Methods for collection and analysis of water samples for dissolved minerals and gases: U.S. Geological Survey Techniques of Water-Resources Investigations, Book 5, Chapter A1, $160 \mathrm{p}$.

Canton, S. P., and Ward, J. V., 1977, Effects of coal mine drainage on macroinvertebrates of Trout Creek, Colorado: Fort Collins, Colorado State University, Environmental Research Paper 9, April 1977, 13 p.

Clement, R. W., 1978, Temperature in streams of New Mexico for the period October 1964 to September 1969: U.S. Geological Survey Water-Resources Investigations 78-140, 30 p.; available from U.S. Department of Commerce, National Technical Information Service, Springfield, VA 22161, as Report PB-299 360.

Collings, M. R., 1969, Temperature analysis of a stream: U.S. Geological Survey Professional Paper 650-B, p. B174-B179.

Colorado Department of Health, 1977a, Primary drinking water regulations (proposed July 19, 1977; corrected after August 31, 1977, hearing):

Denver, $59 \mathrm{p}$. 
Colorado Department of Health, 1977b, Proposed water quality standards for Colorado (draft no. 9; November 17, 1977): Denver, $51 \mathrm{p}$.

Conover, W. J., 1971, Practical nonparametric statistics: New York, John Wiley, $462 \mathrm{p}$.

Eddy, R. M., 1975, The effect of point-source discharges on the diversity of benthic invertebrates of the Yampa River, Steamboat Springs to Hayden, Colorado, September 1975: U.S. Environmental Protection Agency, Technical Investigations Branch, Surveillance and Analysis Division, Region VIII, Report SA/TIB-30, $43 \mathrm{p}$.

Giles, T. F., and Brogden, R. E., 1978, Selected hydrologic data, Yampa River basin and parts of the White River basin, northwestern Colorado and south-central Wyoming: U.S. Geological Survey Open-File Report 78-23, $91 \mathrm{p}$.

Gilroy, E. J., and Steele, T. D., 1972, An analysis of sampling-frequency alternatives for fitting a daily stream-temperature model: International Symposium on Uncertainties in Hydrologic and Water Resource Systems, Tucson, Ariz., December 1972, Proceedings, p. 594-608.

Greeson, P. E., Ehlke, T. A., Irwin, G. A., Lium, B. W., and Slack, K. V., eds., 1977, Methods for collection and analysis of aquatic biological and microbiological samples: U.S. Geological Survey Techniques of Water-Resources Investigations, Book 5, Chapter A4, $332 \mathrm{p}$.

Hem, J. D., 1970, Study and interpretation of the chemical characteristics of natural water, 2d edition: U.S. Geological Survey Water-Supply Paper $1473,363 \mathrm{p}$.

lorns, W. V., Hembree, C. H., and Oakland, G. L., 1965, Water resources of the Upper Colorado River Basin--Technical report: U.S. Geological Survey Professional Paper $441,370 \mathrm{p} ., 9 \mathrm{pl}$.

lorns, W. V., Hembree, C. H., Phoen ix, D. A., and Oakland, G. L., 1964, Water resources of the Upper Colorado River Basin--Basic data: U.S. Geological Survey Professional Paper 442, 1036 p., 4 pl.

Klein, D. H., Andren, A. W., Carter, J. A., Emery, J. F., and others, 1975, Pathways of thirty-seven trace elements through coal-fired power plant: Environmental Science and Technology, v. 9, p. 973-979.

Limerinos, J. T., 1978, Evaluation of thermograph data for California streams: U.S. Geological Survey Water-Resources Investigations 78-66, 38 p.; available from U.S. Department of Commerce, National Technical Information Service, Springfield, VA 22161, as Report PB-288 500.

Lowham, H. W., 1978, An analysis of stream temperatures, Green River basin, Wyoming: U.S. Geological Survey Water-Resources Investigations 78-13, 41 p.; available from U.S. Department of Commerce, National Technical Information Service, Springfield, VA 22161, as Report PB-284 062.

Malo, B. A., 1977, Partial extraction of metals from aquatic sediments: Environmental Science and Technology, v. 11, p. 277-282.

McWhorter, D. B., and Rowe, J. W., 1976, Inorganic water quality in a surface mined watershed: Paper presented at the American Geophysical Union Symposium on Methodologies for Environmental Assessments in Energy Development Regions, San Francisco, Calif., December 8, 1976, 27 p.

Miesch, A. T., 1967, Methods of computation for estimating geochemical abundance: U.S. Geological Survey Professional Paper 574-B, P. B1-B1.5. 
Moran, R. E., 1974, Trace element content of a stream affected by metal-mine drainage, Bonanza, Colorado: University of Texas at Austin, unpublished Ph. D. dissertation, $167 \mathrm{p}$.

Moran, R. E., and Wentz, D. A., 1974, Effects of metal-mine drainage on water quality in selected areas of Colorado, 1972-73: Colorado Water Conservation Board Water-Resources Circular 25, $250 \mathrm{p}$.

Rickert, D. A., Kennedy, V. C., McKenzie, S. W., and Hines, W. G., 1977, A synoptic survey of trace metals in bottom sediments of the Willamette River, Oregon: U.S. Geological Survey Circular 715-F, p. F1-F27.

Rickmers, A. D., and Todd, H. N., 1967, Statistics--An introduction: New York, McGraw-Hill, 585 p.

Shampine, W. J., 1977, Indiana stream-temperature characteristics: U.S. Geological Survey Water-Resources Investigations 77-6, 55 p.; available from U.S. Department of Commerce, National Technical Information Service, Springfield, VA 22161 , as Report PB-265 346.

Slack, K. V., Averett, R. C., Greeson, P. E., and Lipscomb, R. G., 1973, Methods for collection and analysis of aquatic biological and microbiological samples: U.S. Geological Survey Techniques of WaterResources Investigations, Book 5, Chapter A4, $165 \mathrm{p}$.

Stearns-Roger Corp., 1971, Hayden unit 2 coal-fired generating station, Hayden, Colorado--Applicants' environmental analysis: Prepared for Colorado-Ute Electric Association, Inc., Montrose, Colo., and Salt River Project Agricultural Improvement and Power District, Phoenix, Ariz., June $1971,114 \mathrm{p}$. and app.

Stearns-Roger, Inc., 1973-76, Environmental study, Hayden and Craig, Colorado--Phase $C$ final report and phase D annual reports: Prepared for Yampa Project Environmental Task Force, annual volumes.

Steele, T. D., 1973, Simulation of major inorganic chemical concentrations and loads in streamflow: Washington, D.C., U.S. Geological Survey Computer Contribution, 153 p.; available from U.S. Department of Commerce, National Technical Information Service, Springfield, VA 22161 , as Report PB-222 556.

1974, Harmonic analysis of stream temperatures: Reston, Va., U.S. Geological Survey Computer Contribution, 246 p.; available from U.S. Department of Commerce, National Technical Information Service, Springfield, VA 22161, as Report PB-239 016.

1976, Coal-resource development alternatives, residuals management, and impacts on the water resources of the Yampa River basin, Colorado and Wyoming, in Symposium on Water Resources and Fossil Fuel Production, Düsseldorf, Germany, September 7-8, 1976, Proceedings: International Water Resources Association, Paper 28, $18 \mathrm{p}$.

Steele, T. D., Bauer, D. P., Wentz, D. A., and Warner, J. W., 1976a, An environmental assessment of impacts of coal development on the water resources of the Yampa River basin, Colorado and Wyoming--Phase-1 work plan: U.S. Geological Survey Open-File Report 76-367, 17 p.

1979, The Yampa River basin, Colorado and Wyoming--A preview to expanded coal-resource development and its impacts on regional water resources: U.S. Geological Survey Water-Resources Investigations 78-126, 133 p.; available from U.S. Department of Commerce, National Technical Information Service, Springfield, VA 22161, as Report PB-300 815. 
Steele, T. D., and Dyar, T. R., 1974, Harmonic analys is of water temperatures of Georgia streams [abs.]: American Geophysical Union Transactions, EOS, v. 55, no. 12, Paper H-6, December 1974, p. 1114.

Steele, T. D., Gilroy, E. J., and Hawkinson, R. 0., 1974, An assessment of areal and temporal variations in streamflow quality using selected data from the National Stream Quality Accounting Network: U.S. Geological Survey Open-File Report 74-217, $210 \mathrm{p}$.

Steele, T. D., James, I. C., I1, Bauer, D. P., and others, 1976b, An environmental assessment of impacts of coal development on the water resources of the Yampa River basin, Colorado and Wyoming--Phase-1I work plan: U.S. Geological Survey Open-File Report 76-368, 33 p.

Steele, T. D., Wentz, D. A., and Warner, J. W., 1978, Hydrologic reconnaissance of the Yampa River during low flow, Dinosaur National Monument, northwestern Colorado: U.S. Geological Survey Open-File Report 78-226, $10 \mathrm{p}$.

Stratton, C. L., and Lee, G. F., 1975, Cooling towers and water quality: Water Pollution Control Federation Journal, v. 47, p. 1901-1912.

Udis, Bernard, Adams, T. H., Hess, R. C., and Orr, D. V., 1977, Coal energy development in Moffat and Routt Counties of the Yampa River basin in Colorado--Projected primary and secondary economic impacts resulting from several coal-development features: U.S. Geological Survey, Contract P. 0. 12185, June 1977, 342 p.

U.S. Environmental Protection Agency, 1976a, National interim primary drinking water regulations: U.S. Environmental Protection Agency, 570/9-76$003,159 \mathrm{p}$.

1976b, Interim primary drinking water regulations--Promulgation of regulations on radionuclides: Federal Register, v. 41, no. 133, Friday, July 9, 1976, Part 11, p. 28402-28409.

1977, National secondary drinking water regulations: Federal Register, v. 42, no. 62, Thursday, March 31, 1977, Part I, p. 17143-17147.

U.S. Geological Survey, 1976, Hydrologic studies of the U.S. Geological Survey related to coal development in Colorado: U.S. Geological Survey Open-File Report 76-549, 22 p.

1978, Water resources data for Colorado--Water year 1977: U.S. Geological Survey Water-Data Report C0-77-3, $412 \mathrm{p}$.

Vanderwilt, J. W., 1947, Mineral resources of Colorado: Denver, Colorado Mineral Resources Board, $547 \mathrm{p}$.

Velz, C. J., 1970, Applied stream sanitation: New York, John Wiley, 619 p.

Ward, J. C., 1963, Annual variation of stream water temperature: American Society of Civil Engineers, Journal of Sanitary Engineering Division, v. 89 , no. SA6, p. 1-16.

Wentz, D. A., 1974a, Effect of mine drainage on the quality of streams in Colorado, 1971-72: Colorado Water Conservation Board Water-Resources

Circular $21,117 \mathrm{p}$.

1974b, Stream quality in relation to mine drainage in Colorado: American Water Resources Association Proceedings 18, p. 158-173.

Wentz, D. A., and Steele, T. D., 1978, Surface-water quality in the Yampa River basin, Colorado and Wyoming--An area of accelerated coal development, in Karadi, G. M. and Krizek, R. J. (eds.), Water for Energy Development: Asilomar Conference Center, Pacific Grove, Calif., December 5-10, 1976, Proceedings, p. 56-74. 
Wilhm, J. L., and Dorris, T. C., 1968, Biological parameters for water quality criteria: Bioscience, v. 18, p. 477-481.

Wyoming Department of Environmental Quality, 1978, Water quality, rules and regulations, Chapter I, Quality standards for Wyoming surface waters: Cheyenne, Water Quality Division, 16 p. 
SUPPLEMENTAL INFORMATION

Stream Quality during Low Flow

Precision of Chemical-Constituent Concentrations 
Table 17.--Precision of chemical-constituent concentrations in streams of the Yampa River basin, August-September 1975

\begin{tabular}{|c|c|c|c|}
\hline Constituent & $\begin{array}{l}\text { Number of } \\
\text { duplicate } \\
\text { samples }\end{array}$ & $\begin{array}{l}\text { Range of } \\
\text { mean }\end{array}$ & $\begin{array}{l}\text { Range of } \\
\text { standard } \\
\text { deviation } \\
\end{array}$ \\
\hline $\begin{array}{l}\text { Dissolved solids, } \mathrm{mg} / \mathrm{L} \text { (milligrams per liter) } \\
\text { Calcium, mg/L } \\
\text { Magnesium, mg/L } \\
\text { Potassium, mg/L } \\
\text { Sodium, mg/L }\end{array}$ & $\begin{array}{l}3 \\
3 \\
3 \\
3 \\
3\end{array}$ & $\begin{array}{l}370-540 \\
68-90 \\
22-55 \\
3.2-3.8 \\
14-43\end{array}$ & $\begin{array}{c}0-12 \\
.71-2.1 \\
0-7.1 \\
.071 \\
0-.71\end{array}$ \\
\hline $\begin{array}{l}\text { Bicarbonate, } \mathrm{mg} / \mathrm{L} \\
\text { Chloride, } \mathrm{mg} / \mathrm{L} \\
\text { Fluoride, } \mathrm{mg} / \mathrm{L} \\
\text { Sulfate, } \mathrm{mg} / \mathrm{L} \\
\text { Silica, } \mathrm{mg} / \mathrm{L}\end{array}$ & $\begin{array}{l}3 \\
3 \\
3 \\
4 \\
3\end{array}$ & $\begin{array}{l}200-320 \\
2.0-5.6 \\
.20-.35 \\
140-1,800 \\
1.4-18\end{array}$ & $\begin{array}{r}0-5.0 \\
.21-.42 \\
0-.71 \\
0-71 \\
.071-.71\end{array}$ \\
\hline $\begin{array}{l}\text { Dissolved organic carbon, } \mathrm{mg} / \mathrm{L} \\
\text { Suspended organic carbon, } \mathrm{mg} / \mathrm{L} \\
\text { Dissolved Kjeldahi nitrogen, } \mathrm{mg} / \mathrm{L} \text { as } \\
\text { Total Kjeldahl nitrogen, } \mathrm{mg} / \mathrm{L} \text { as } \mathrm{N} / \mathrm{L} \text { as } \mathrm{N} \\
\text { Dissolved nitrite p!us nitrate, } \mathrm{mg} / \mathrm{L} \text {. }\end{array}$ & $\begin{array}{l}6 \\
4 \\
6 \\
6 \\
6\end{array}$ & $\begin{array}{l}5.8-14 \\
.35-1.0 \\
.16-.60 \\
.34-1.2 \\
0-.50\end{array}$ & $\begin{array}{r}.71-8.6 \\
0-.21 \\
.028-.11 \\
0-.23 \\
0-.014\end{array}$ \\
\hline $\begin{array}{l}\text { Total nitrite plus nitrate, } \mathrm{mg} / \mathrm{L} \text { as } \mathrm{N} \\
\text { Dissolved phosphorus, } \mathrm{mg} / \mathrm{L} \text { as } \mathrm{P} \\
\text { Total phosphorus, } \mathrm{mg} / \mathrm{L} \text { as } \mathrm{P} \\
\text { Dissolved cadmium, } \mu \mathrm{g} / \mathrm{L} \text { (micrograms per liter) } \\
\text { Total cadmium, } \mu \mathrm{g} / \mathrm{L}\end{array}$ & $\begin{array}{l}6 \\
6 \\
6 \\
6 \\
6\end{array}$ & $\begin{array}{c}.010-.52 \\
0-.16 \\
0-.17 \\
0 \\
(2)\end{array}$ & $\begin{array}{l}0-.014 \\
0-.035 \\
0-.035 \\
0 \\
(2)\end{array}$ \\
\hline $\begin{array}{l}\text { Dissolved cobalt, } \mu \mathrm{g} / \mathrm{L} \\
\text { Total cobalt, } \mu \mathrm{g} / \mathrm{L} \\
\text { Dissolved copper, } \mu \mathrm{g} / \mathrm{L} \\
\text { Total copper, } \mu \mathrm{g} / \mathrm{L} \\
\text { Dissolved iron, } \mu \mathrm{g} / \mathrm{L}\end{array}$ & $\begin{array}{l}6 \\
6 \\
6 \\
2 \\
6\end{array}$ & $\begin{array}{l}0-.50 \\
(2)^{0} \\
1.0-540 \\
15-500 \\
15-2,200\end{array}$ & $\begin{array}{l}0-.71 \\
(2) \\
0-14 \\
7.1 \\
0-78\end{array}$ \\
\hline $\begin{array}{l}\text { Total iron, } \mu g / \mathrm{L} \\
\text { Dissolved lead, } \mu \mathrm{g} / \mathrm{L} \\
\text { Total lead, } \mu \mathrm{g} / \mathrm{L} \\
\text { Dissolved manganese, } \mu \mathrm{g} / \mathrm{L} \\
\text { Total manganese, } \mu \mathrm{g} / \mathrm{L}\end{array}$ & $\begin{array}{l}6 \\
6 \\
6 \\
6 \\
6\end{array}$ & $\begin{array}{l}340-3,600 \\
0-12 \\
(2) \\
30-360 \\
30-510\end{array}$ & $\begin{array}{l}0-1,700 \\
0-3.5 \\
(2) \\
0-21 \\
0-85\end{array}$ \\
\hline $\begin{array}{l}\text { Dissolved mercury, } \mu \mathrm{g} / \mathrm{l} \\
\text { Total mercury, } \mu \mathrm{g} / \mathrm{L} \\
\text { Dissolved } n \mathrm{ickel}, \mu \mathrm{g} / \mathrm{L} \\
\text { Total nickel, } \mu \mathrm{g} / \mathrm{L} \\
\text { Dissolved selenium, } \mu \mathrm{g} / \mathrm{L}\end{array}$ & $\begin{array}{l}6 \\
6 \\
6 \\
6 \\
6\end{array}$ & $\begin{array}{l}0-.050 \\
0-.050 \\
.50-6.5 \\
(2) \\
0-2.0\end{array}$ & $\begin{array}{l}0-.071 \\
0-.14 \\
0-1.4 \\
(2) \\
0\end{array}$ \\
\hline $\begin{array}{l}\text { Total selenium, } \mu \mathrm{g} / \mathrm{L} \\
\text { Dissolved vanadium, } \mu \mathrm{g} / \mathrm{L} \\
\text { Dissolved zinc, } \mu \mathrm{g} / \mathrm{L} \\
\text { Total zinc, } \mu \mathrm{g} / \mathrm{L} \\
\text { Bottom antimony, } \mu \mathrm{g} / \mathrm{g} \text { (micrograms per gram) }\end{array}$ & $\begin{array}{l}6 \\
6 \\
5 \\
5 \\
3\end{array}$ & $\begin{array}{r}0-3.0 \\
.45-7.4 \\
0-15 \\
10-35 \\
2.0-5.0\end{array}$ & $\begin{array}{c}0 \\
.071-.71 \\
0-7.1 \\
0-14 \\
0-.71\end{array}$ \\
\hline $\begin{array}{l}\text { Bottom arsenic, } \mu \mathrm{g} / \mathrm{g} \\
\text { Bottom chromium, } \mu \mathrm{g} / \mathrm{g} \\
\text { Bottom copper, } \mu \mathrm{g} / \mathrm{g} \\
\text { Bottom iron, } \mu \mathrm{g} / \mathrm{g} \\
\text { Bottom lead, } \mu \mathrm{g} / \mathrm{g}\end{array}$ & $\begin{array}{l}3 \\
3 \\
3 \\
3 \\
3\end{array}$ & $\begin{array}{l}10-17 \\
10-18 \\
18-260 \\
8,100-21,000 \\
180-300\end{array}$ & $\begin{array}{r}0-3.5 \\
2.8-9.2 \\
0-3.5 \\
500-71.0 \\
0-35\end{array}$ \\
\hline $\begin{array}{l}\text { Bottom mercury, } \mu \mathrm{g} / \mathrm{g} \\
\text { Bottom nickel, } \mu \mathrm{g} / \mathrm{g}\end{array}$ & $\begin{array}{l}3 \\
3\end{array}$ & $\begin{array}{l}.030-.11 \\
9.0-15\end{array}$ & $\begin{array}{l}0-.014 \\
0-1.4\end{array}$ \\
\hline
\end{tabular}

${ }^{1}$ Duplicate samples were collected at sites $Y-46, Y-48, Y-51, Y-60, Y-67$, and $Y-75$ (fig. 1).

${ }^{2}$ Statistics could not be calculated because all values were less than the lower limit of detection. 
Trace Elements in Water 

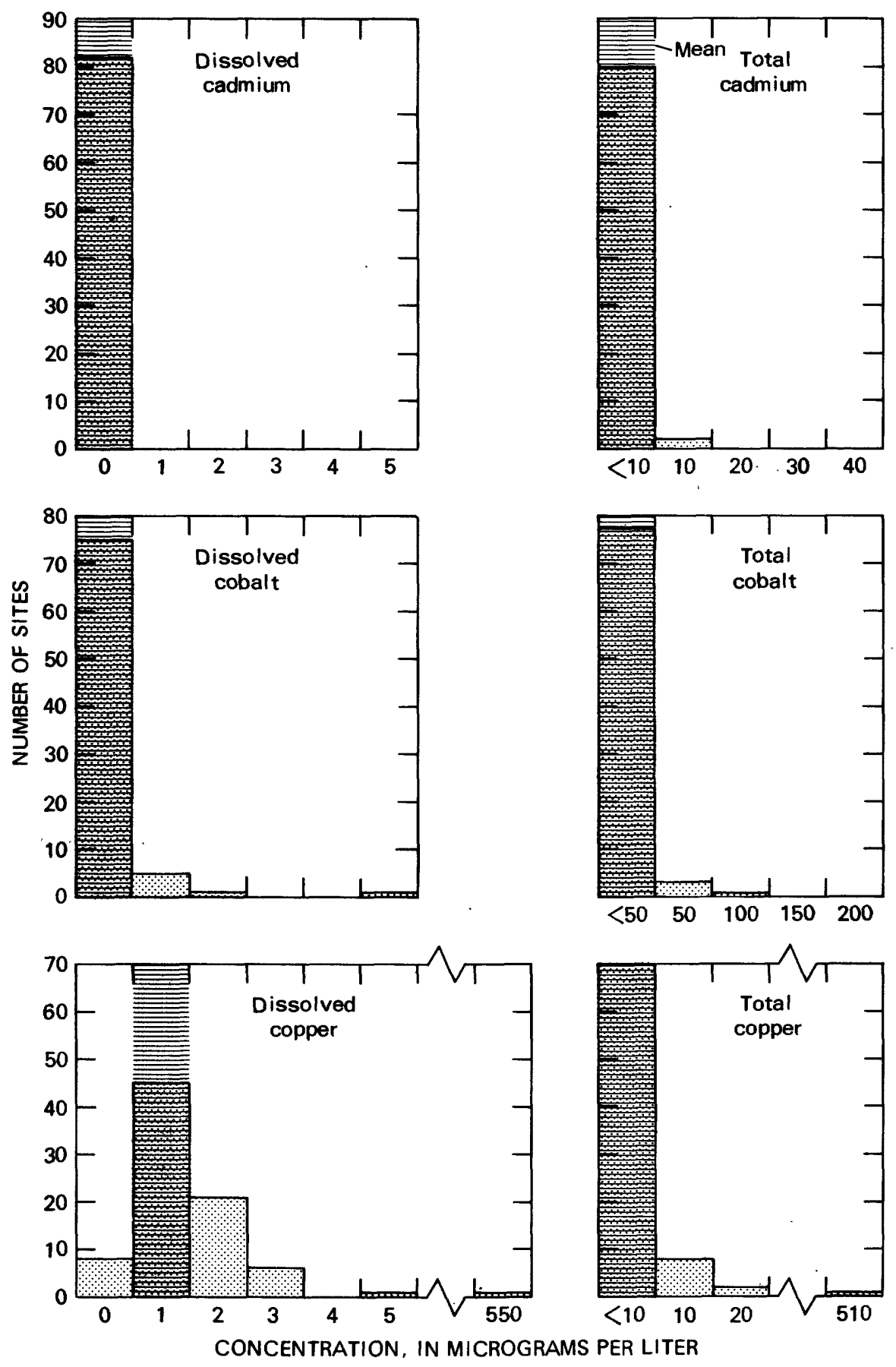

Figure 42.-- Frequency distributions of cadmium, cobalt, and copper in streams of the Yampa River basin, August-September 1975. 

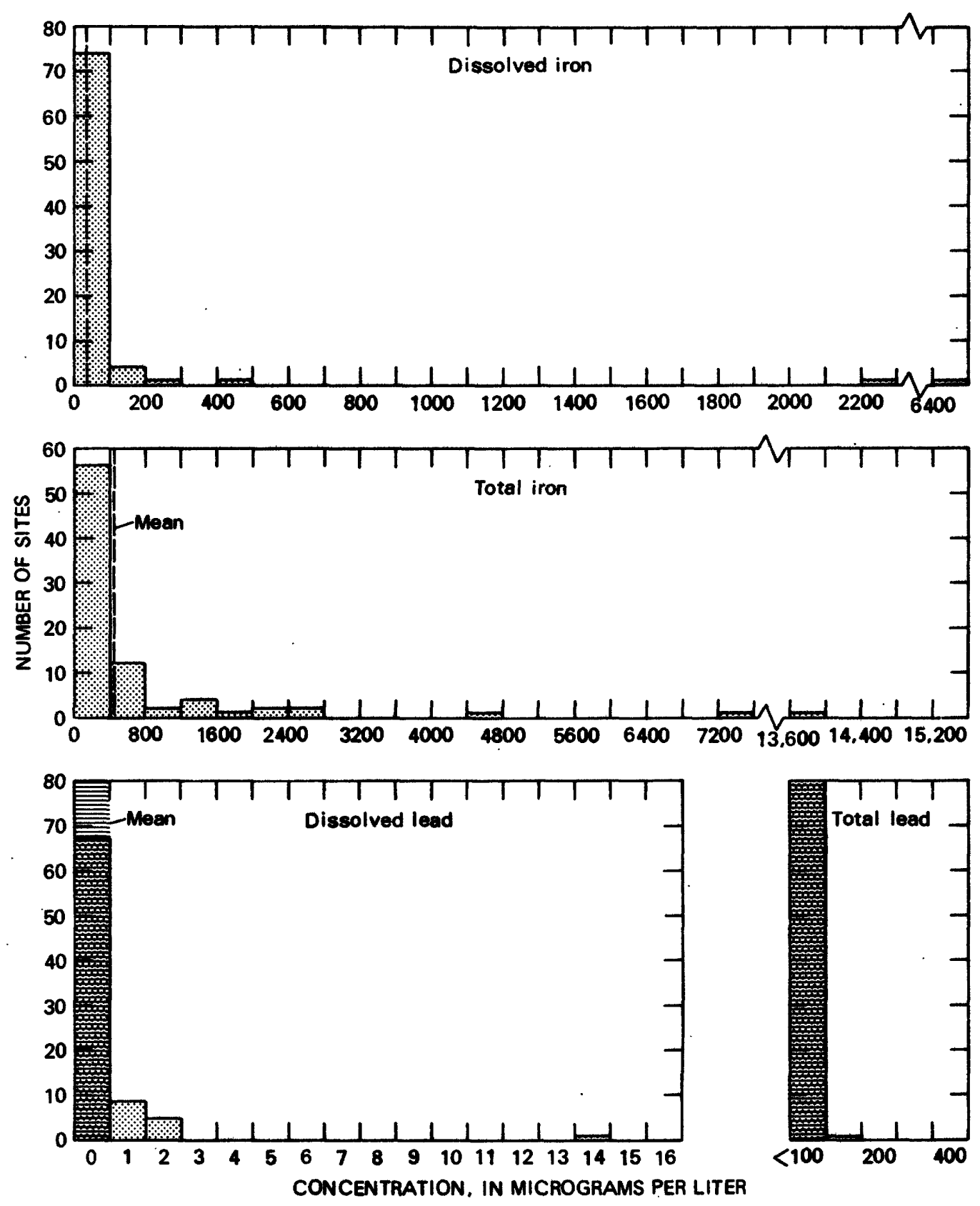

Figure 43.-- Frequency distributions of iron and lead in streams of the Yampa River basin, August-September 1975. 

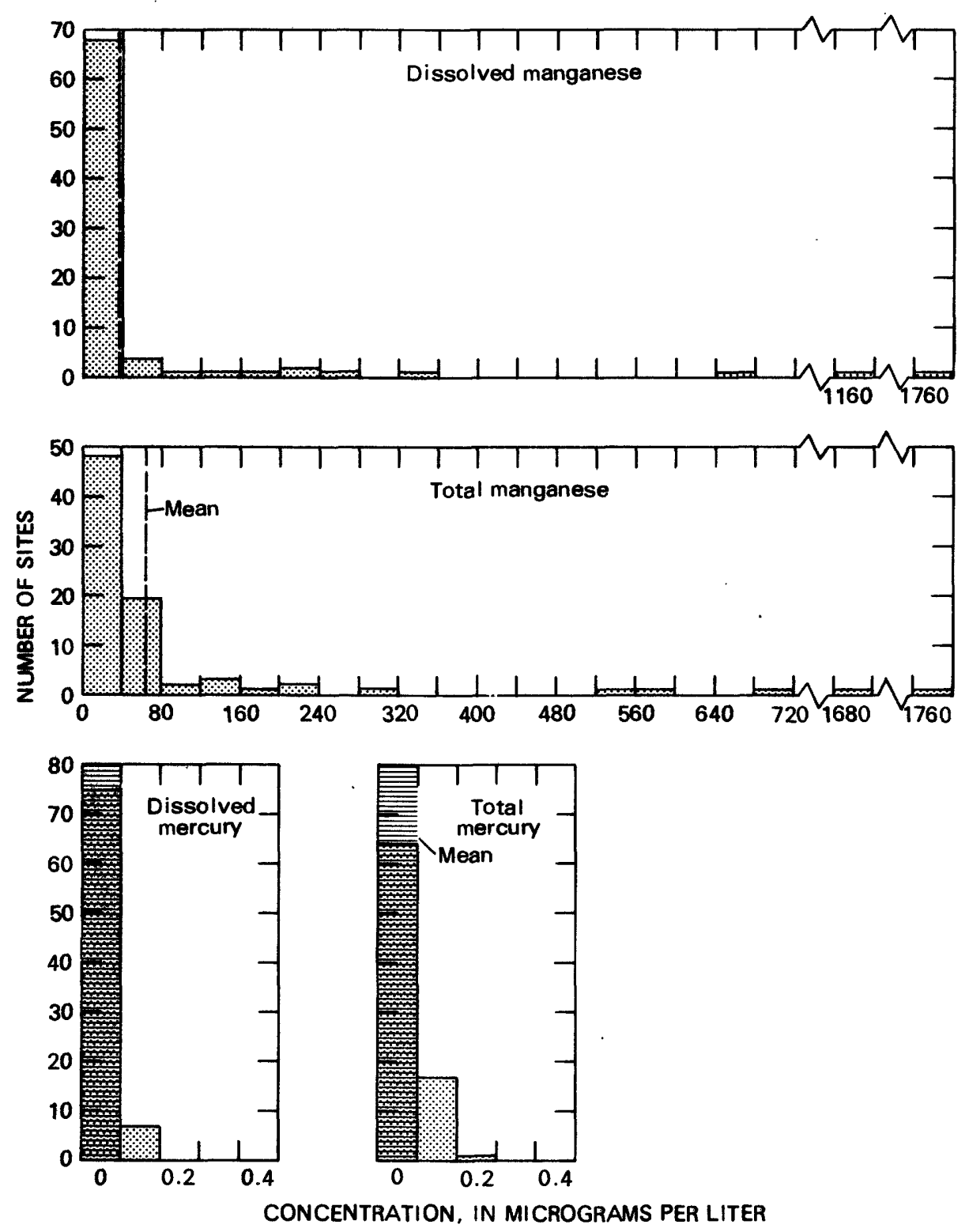

Figure 44.-- Frequency distributions of manganese and mercury in stream s of the Yampa River basin, August-September 1975. 

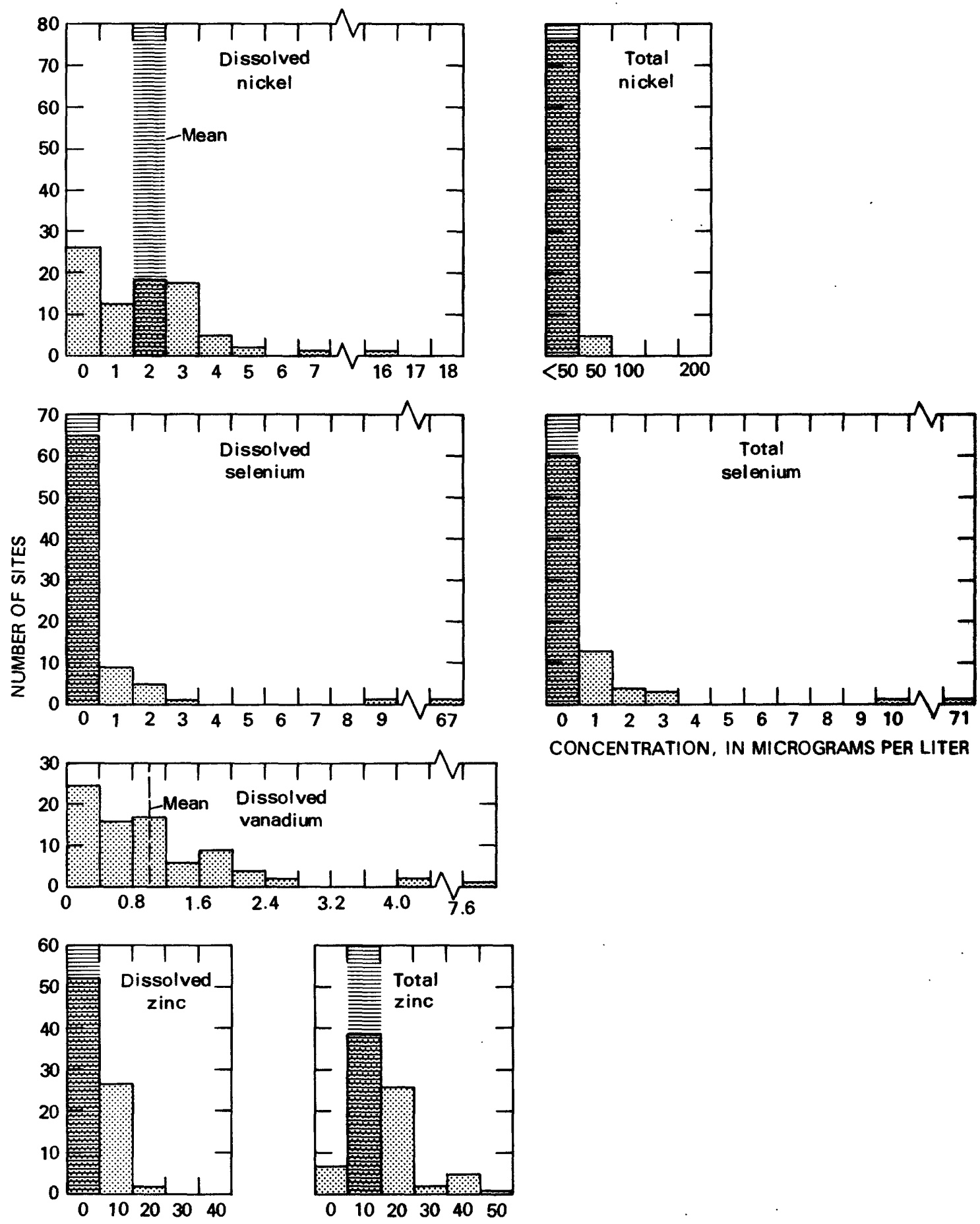

CONCENTRATION, IN MICROGRAMS PER LITER

Figure 45.-- Frequency distributions of nickel, selenium, vanadium, and zinc in streams of the Yampa River basin, August-September 1975. 
. 
Trace Elements in Stream-Bottom Sediments 

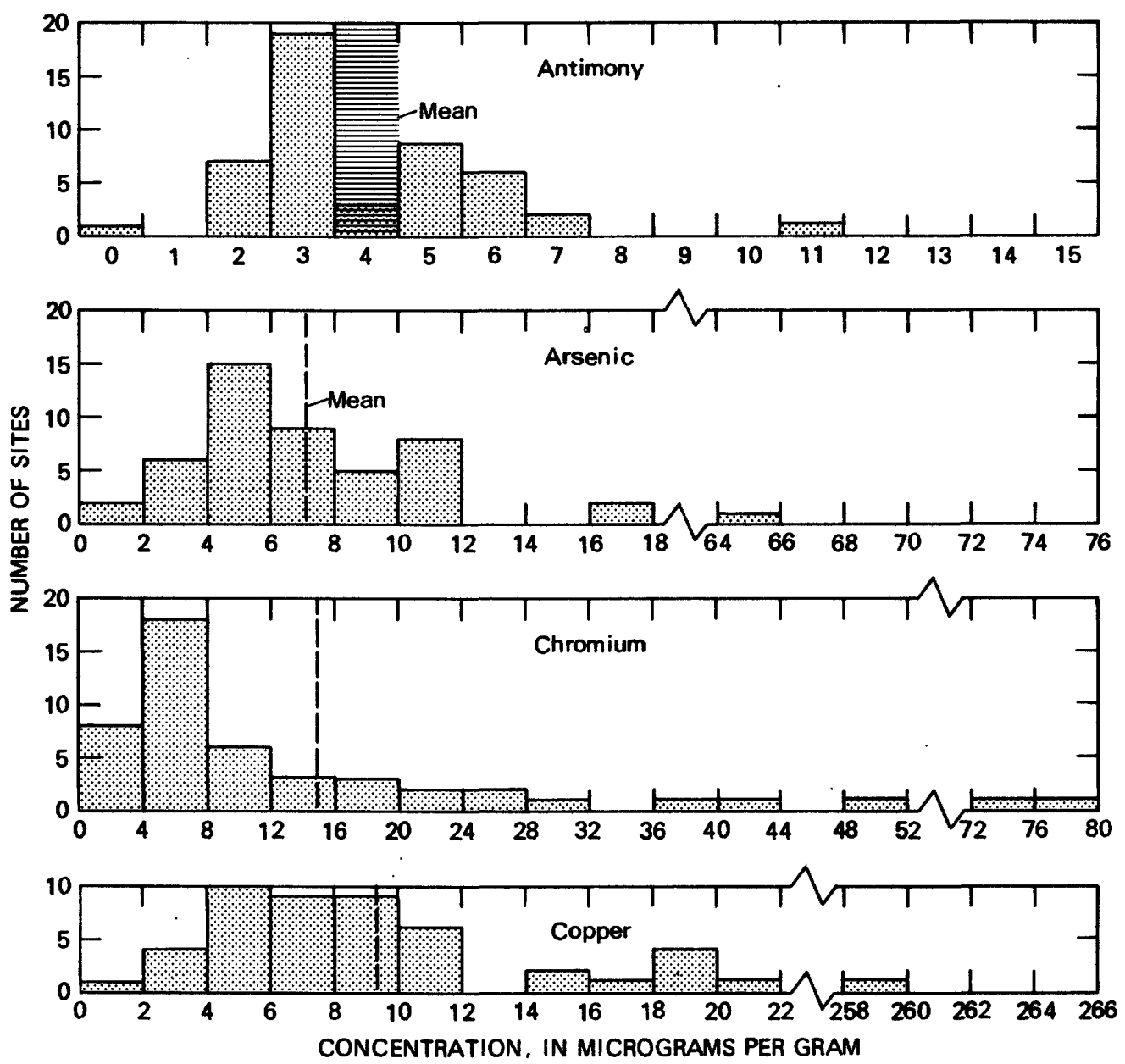

Figure 46.-- Frequency distributions of antimony, arsenic, chromium, and copper in stream-bottom sediments of the Yampa River basin, AugustSeptember 1975. 

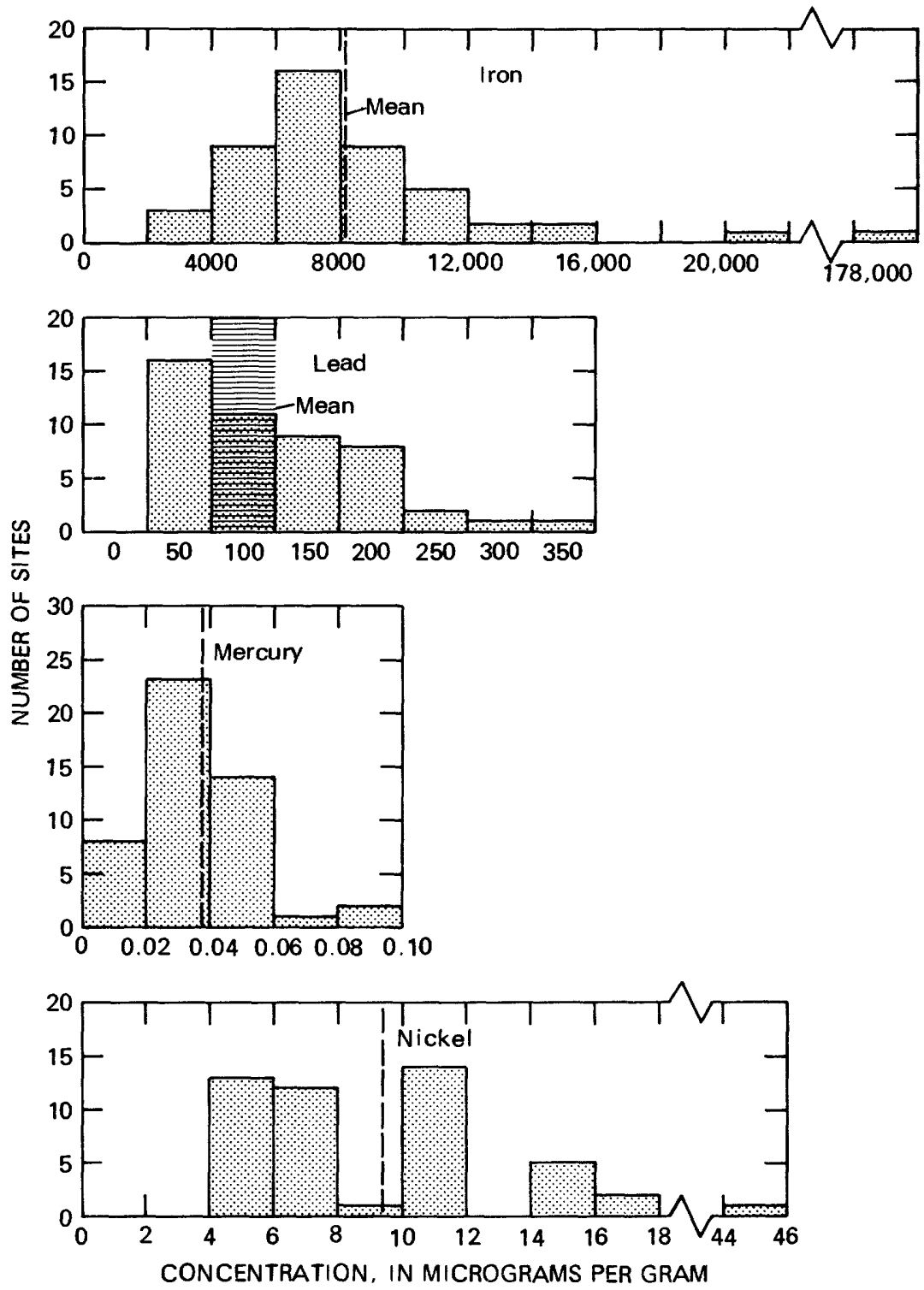

Figure 47.-- Frequency distributions of iron, lead, mercury, and nickel in stream-bottom sediments of the Yampa River basin, August-September 1975. 
Nutrients 

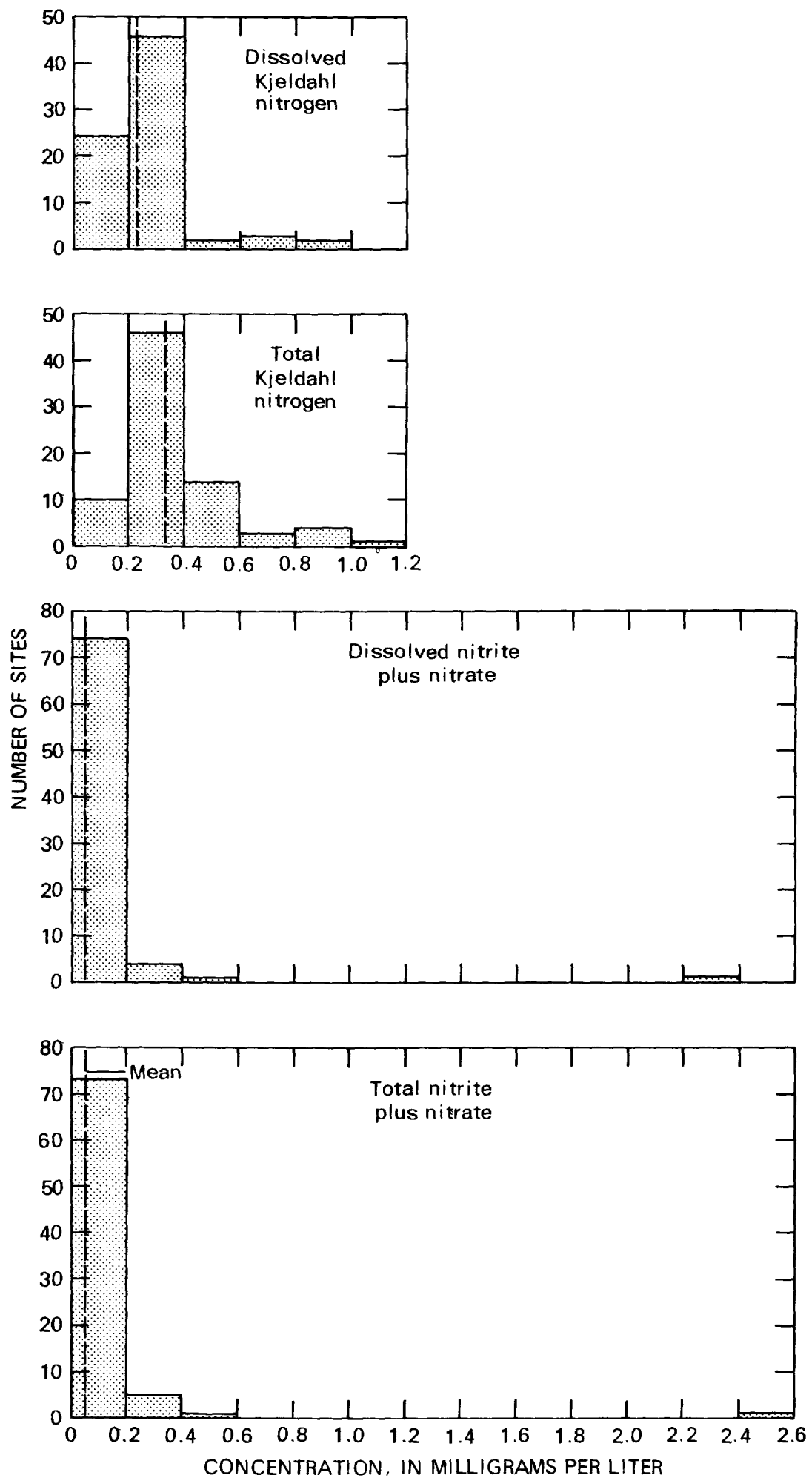

Figure 48.-- Frequency distributions of nitrogen in streams of the Yampa River basin, August-September 1975. 

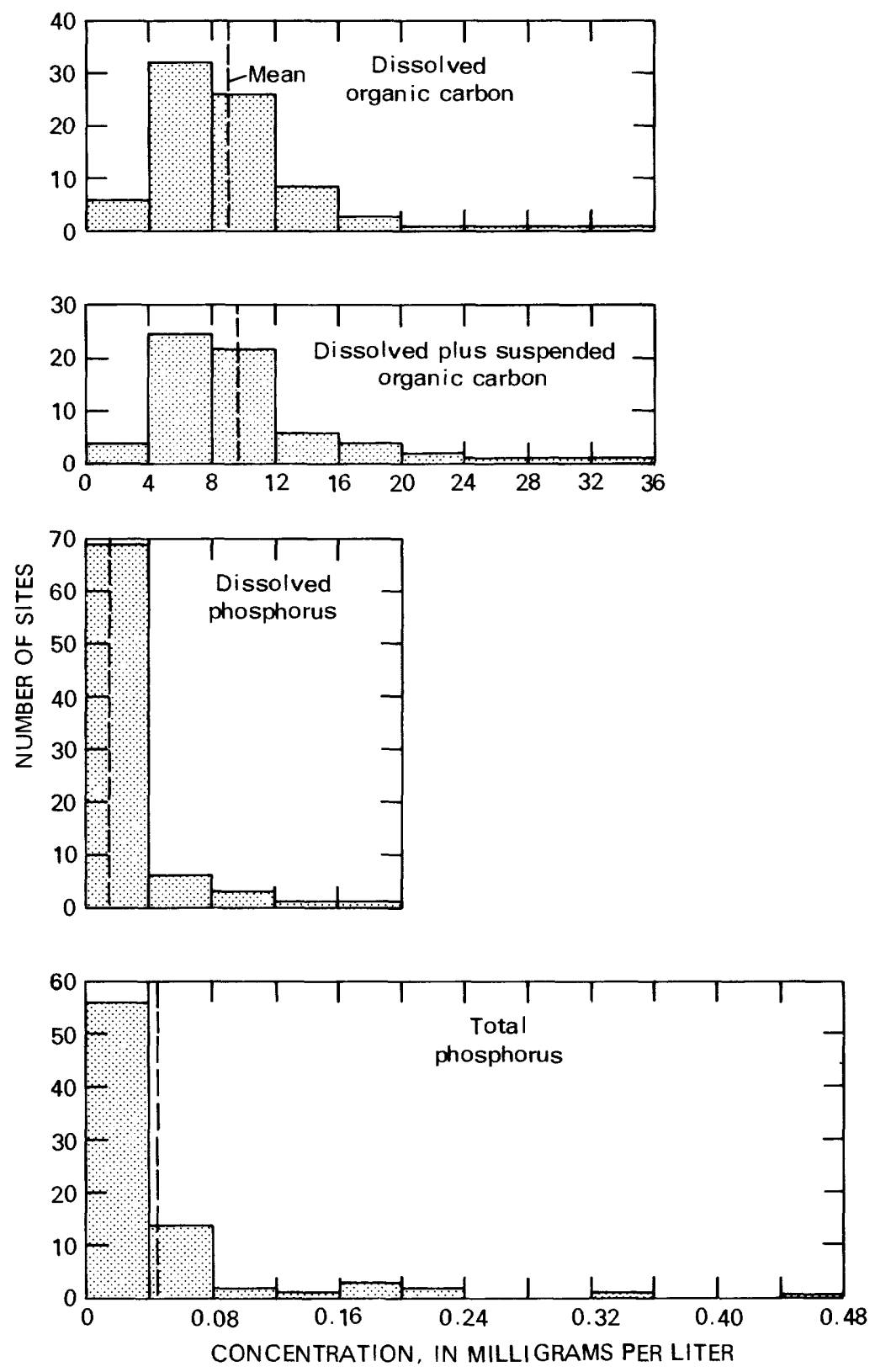

Figure 49.-- Frequency distributions of organic carbon and of phosphorus in streams of the Yampa River basin, August-September 1975 . 

Seasonal Variations in Stream Quality

Trace Elements in Water 

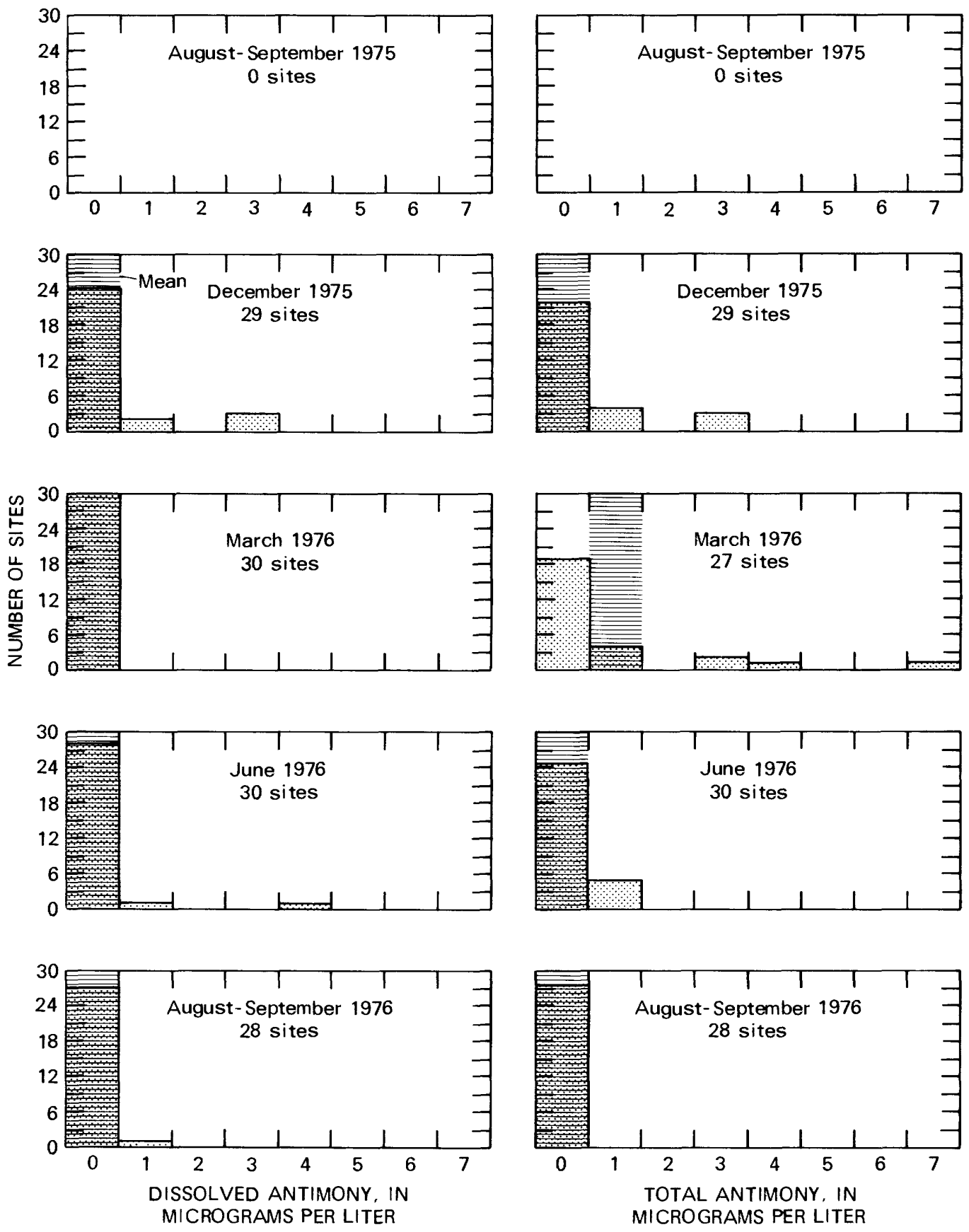

Figure 50.-- Frequency distributions of dissolved and total antimony in streams of the Yampa River basin, August-September 1975 through August-September 1976. 

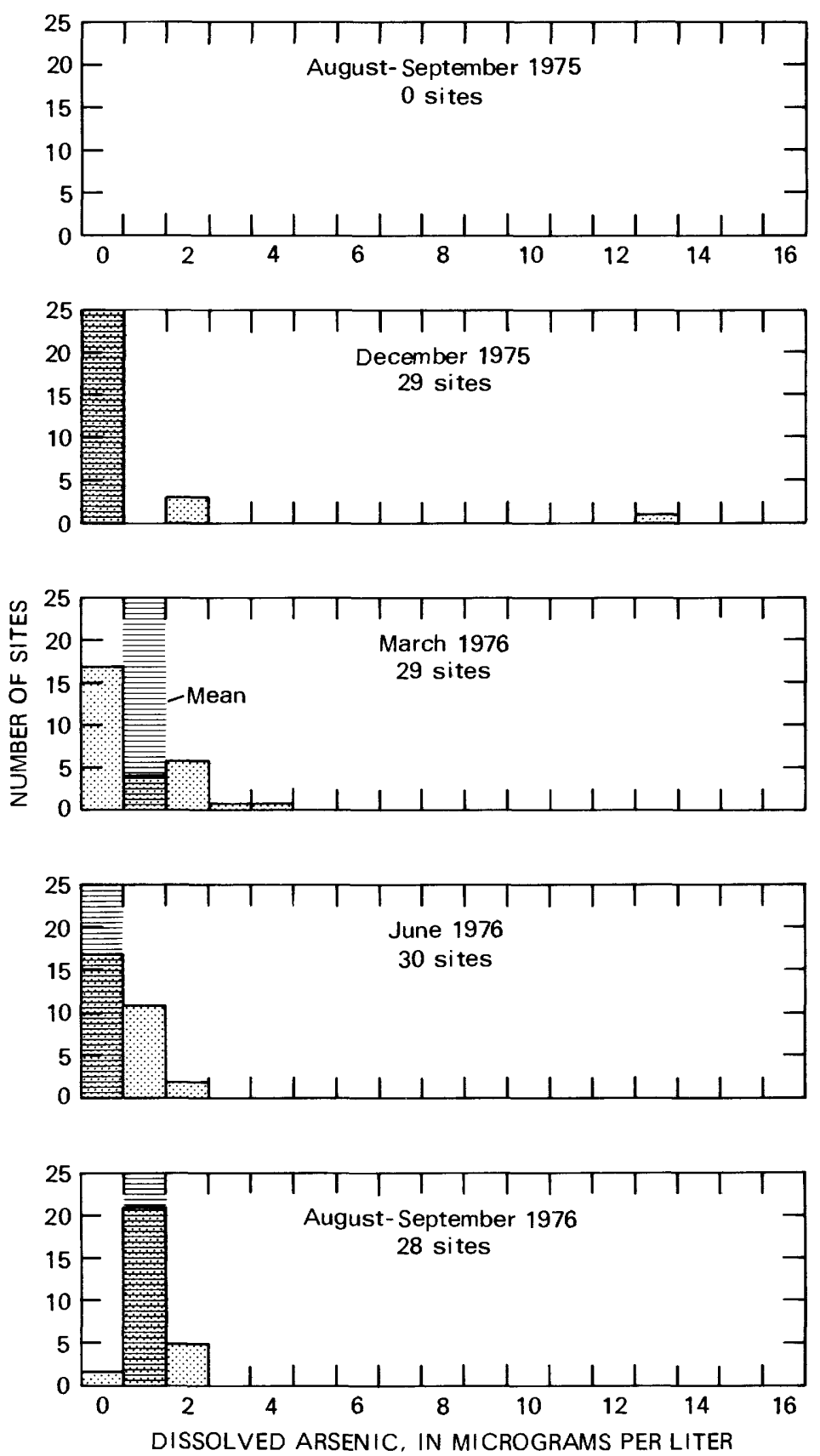

Figure 51.-- Frequency distributions of dissolved arsenic in streams of the Yampa River basin, August-September 1975 through August-September 1976. 

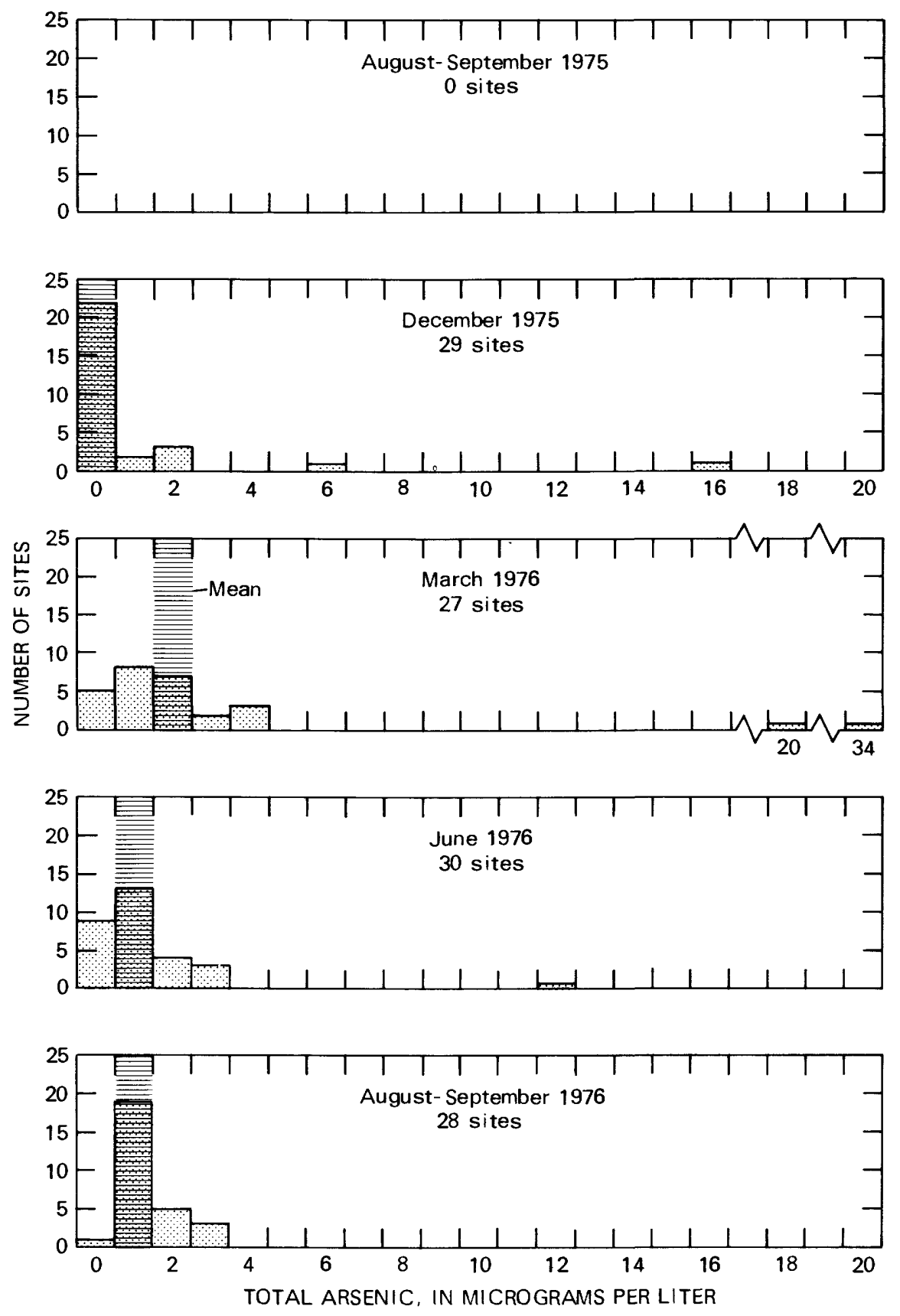

Figure 52.- Frequency distributions of total arsenic in streams of the Yampa River basin, August-September 1975 through AugustSeptember 1976. 

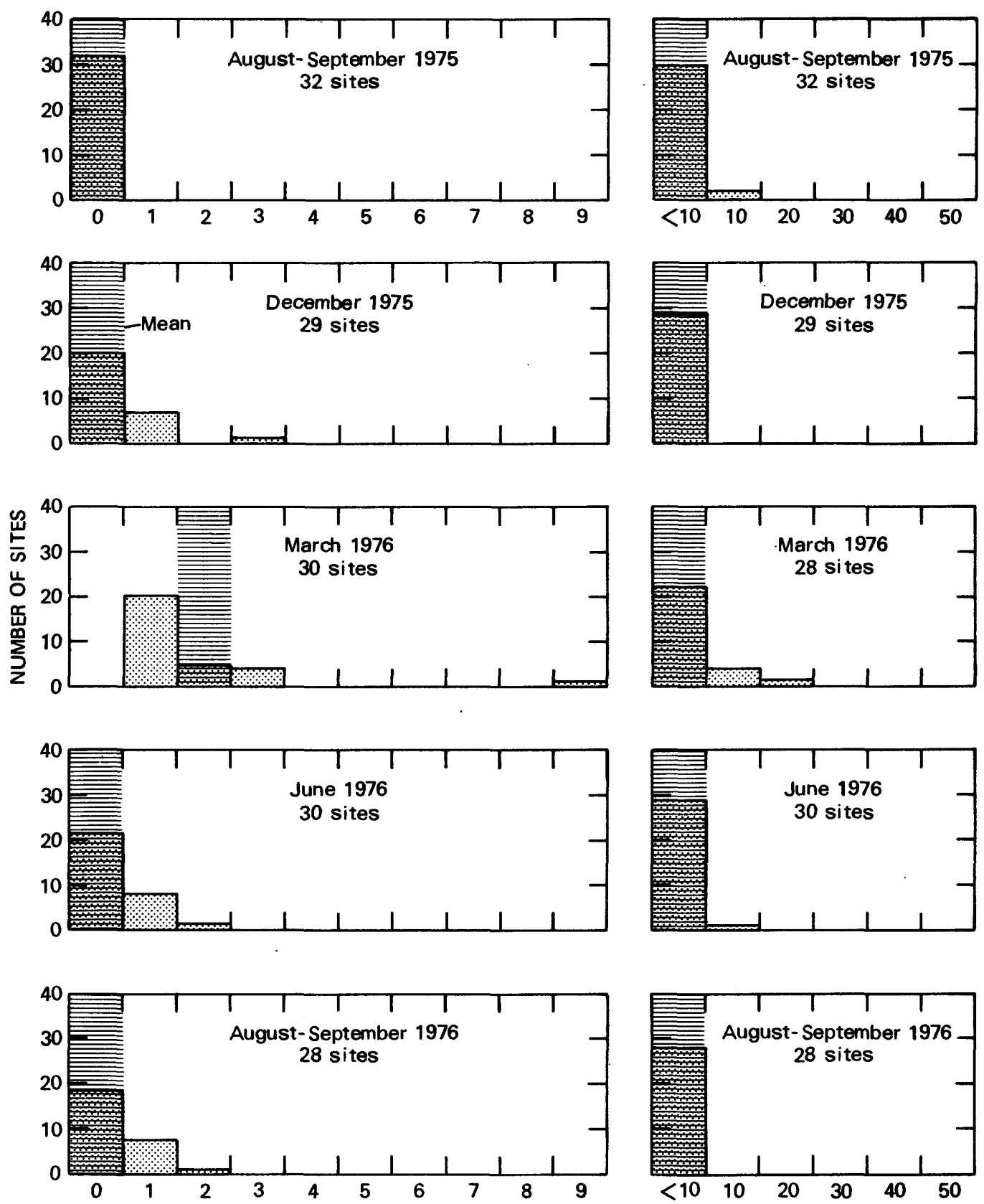

DISSOLVED CADMIUM, IN MICROGRAMS PER LITER

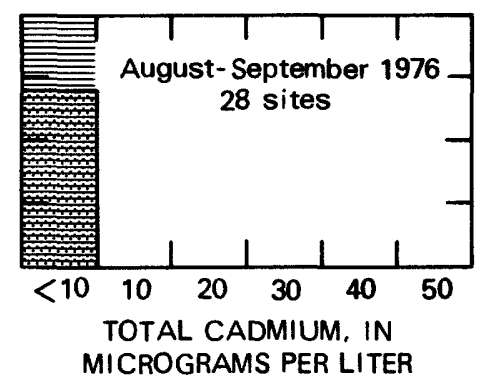

Figure 53.-- Frequency distributions of dissolved and total cadmium in streams of the Yampa River basin, August-September 1975 through August-September 1976. 

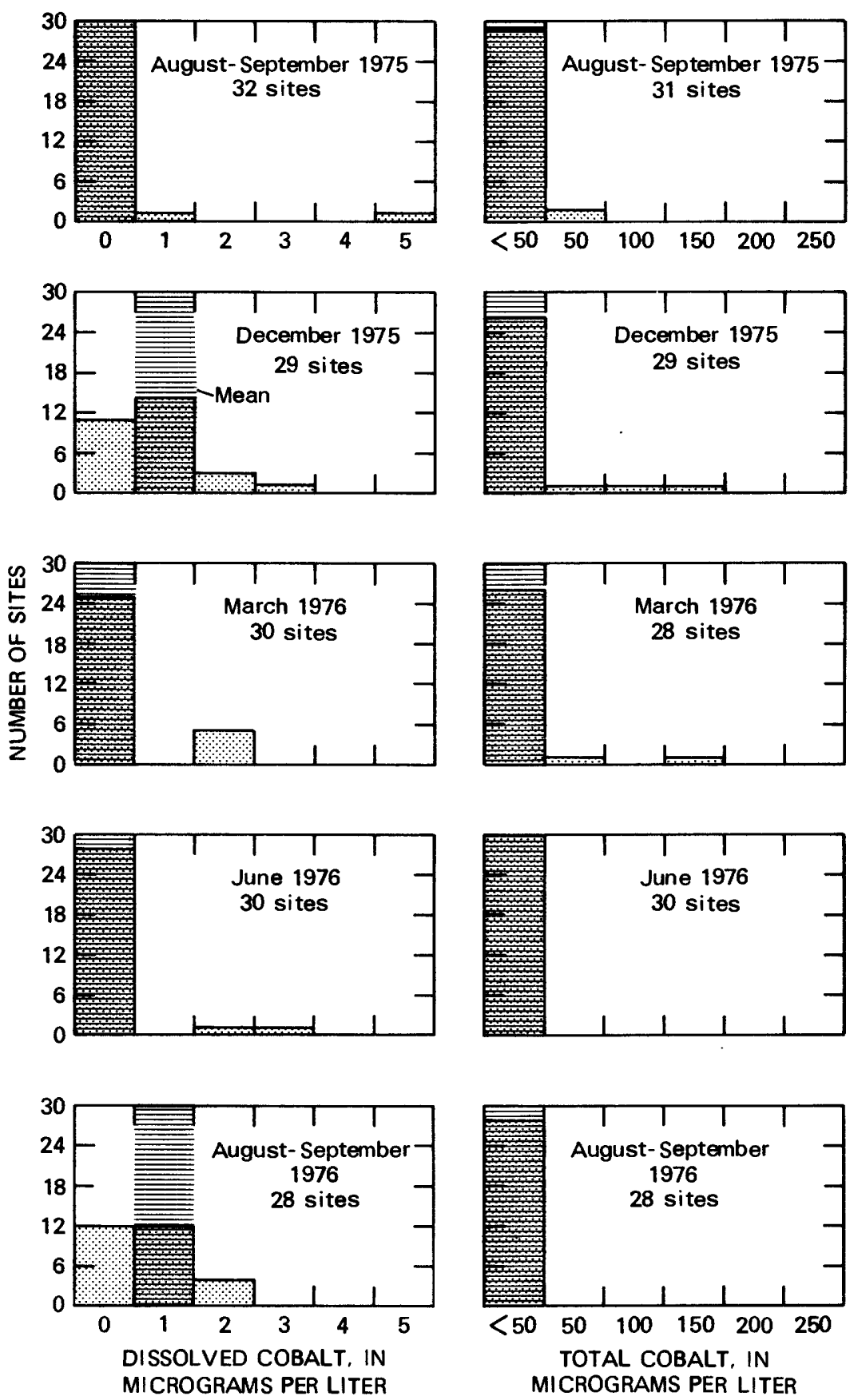

Figure 54.-- Frequency distributions of dissolved and total cobalt in streams of the Yampa River basin, AugustSeptember 1975 through August-September 1976. 

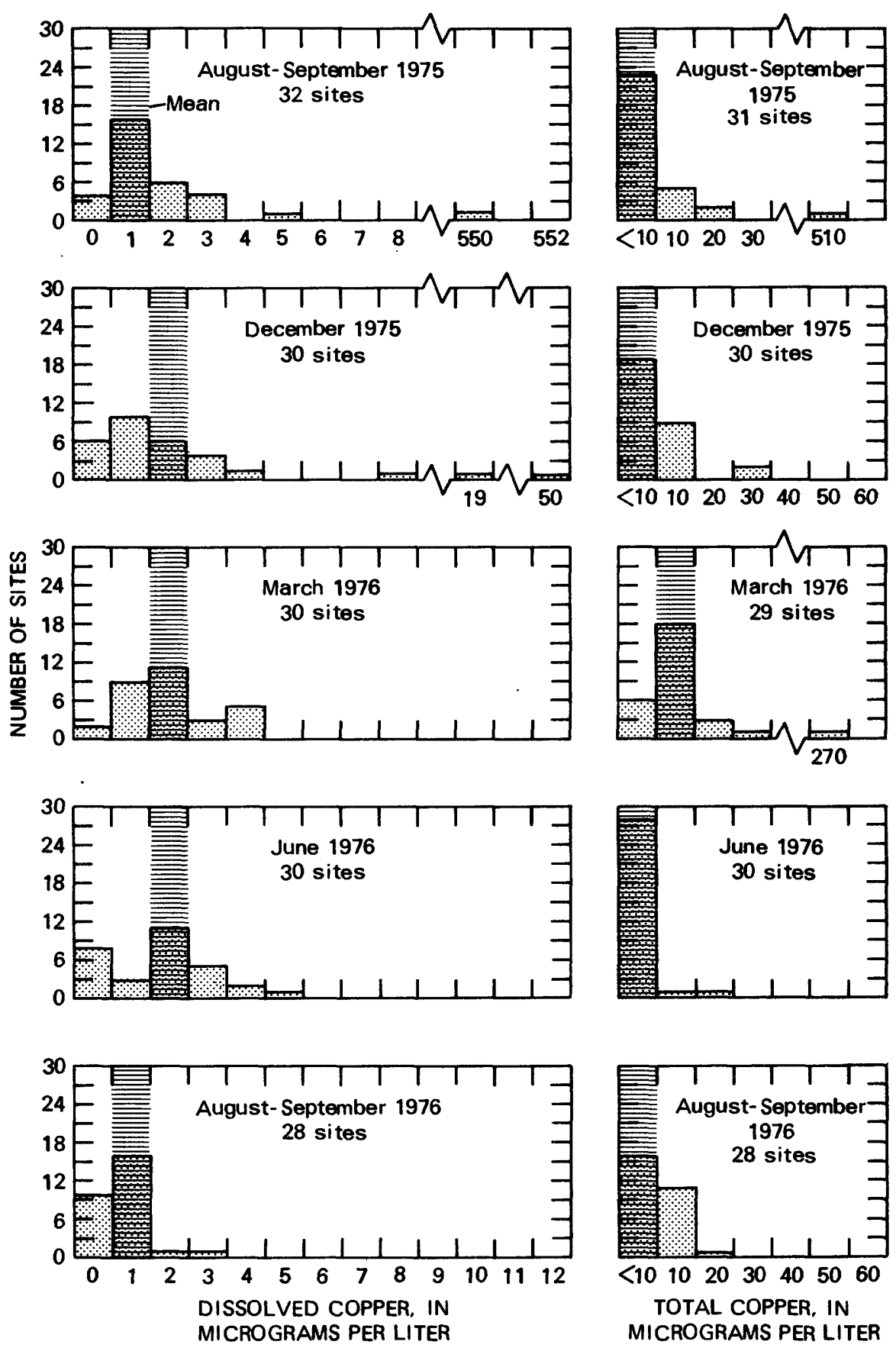

Figure 55.-- Frequency distributions of dissolved and total copper in streams of the Yampa River basin, AugustSeptember 1975 through August-September 1976. 


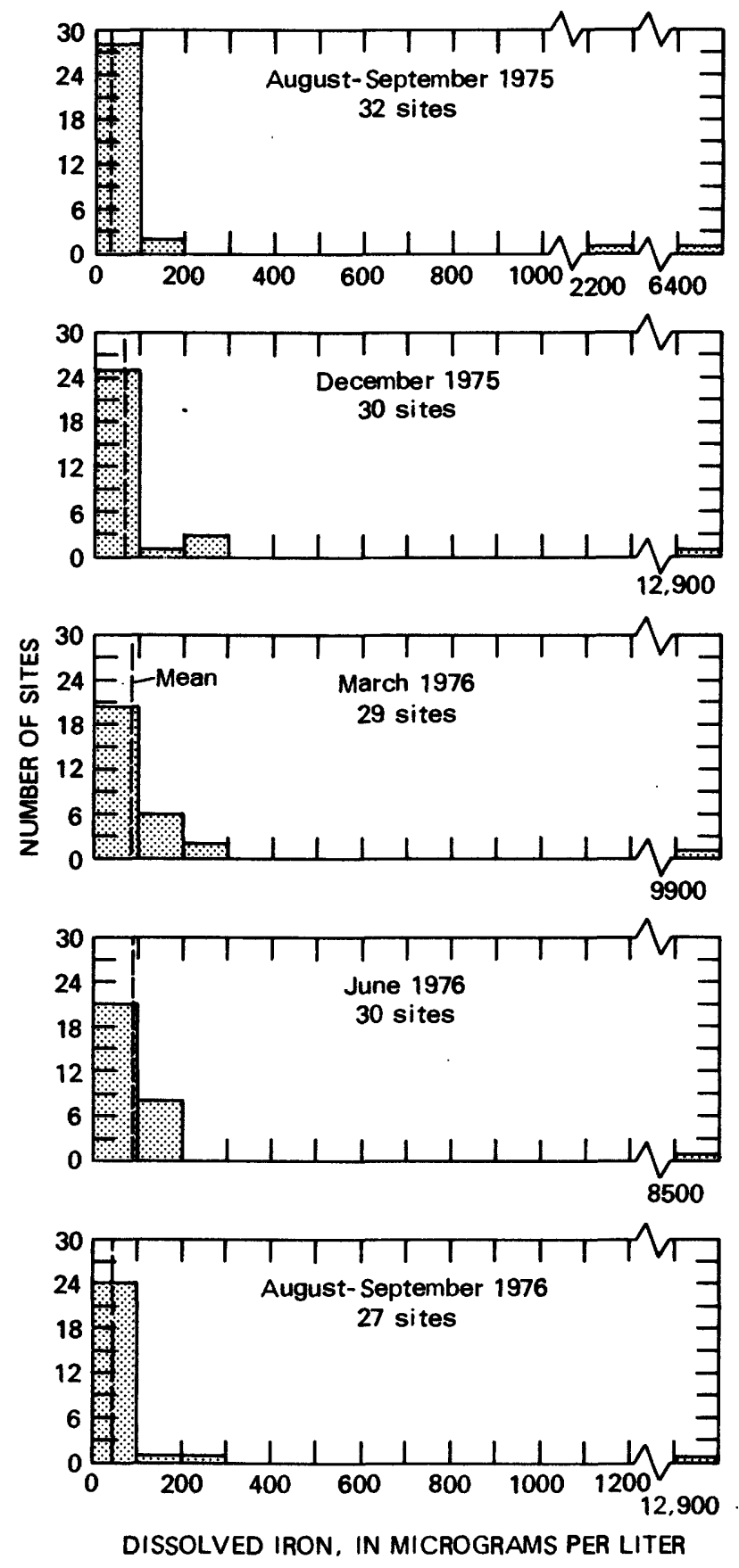

Figure 56.-- Frequency distributions of dissolved iron in stream $s$ of the Yampa River basin, August-September 1975 through August-September 1976. 

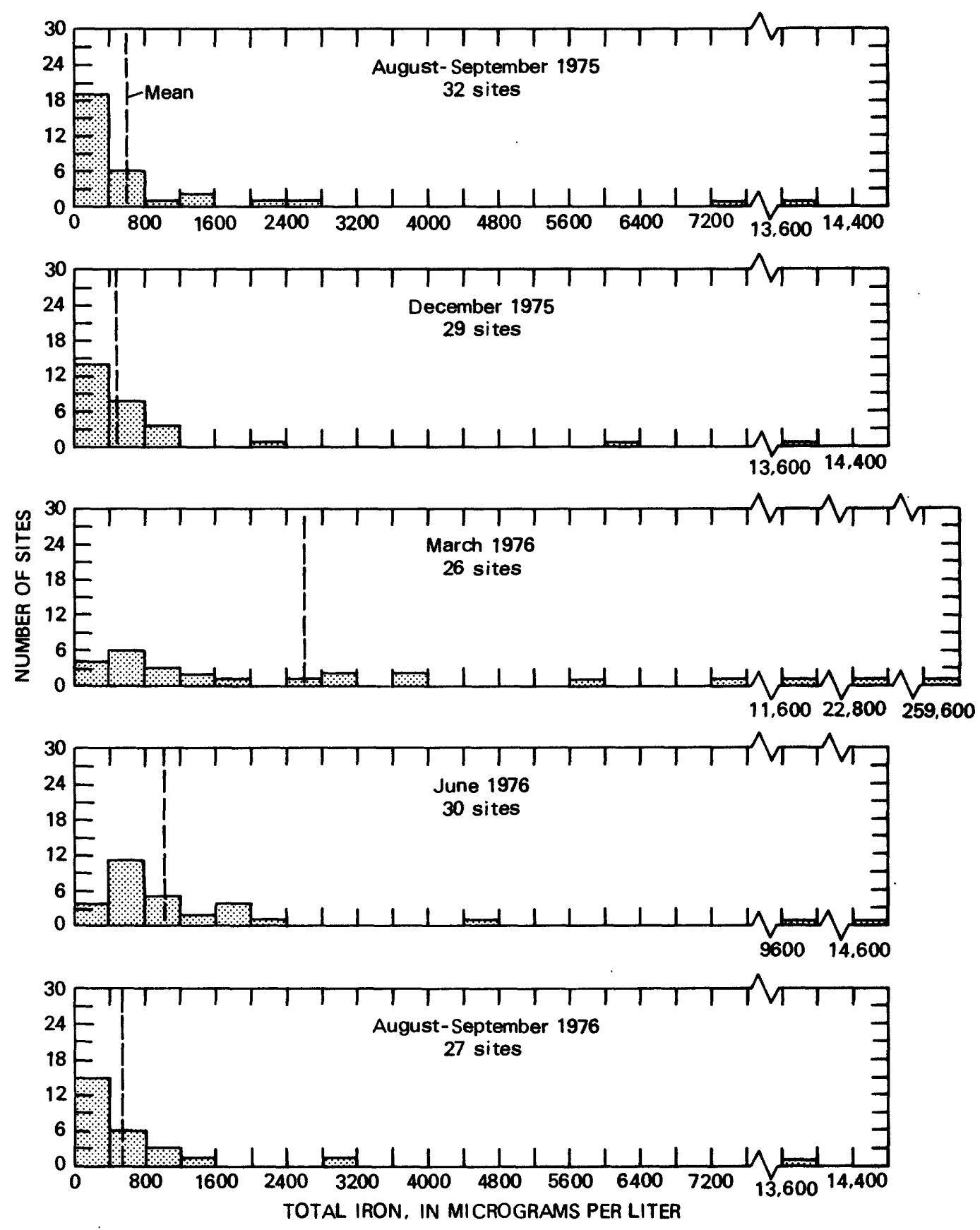

Figure 57.-- Frequency distributions of total iron in streams of the Yampa River basin, August-September 1975 through August-September 1976. 

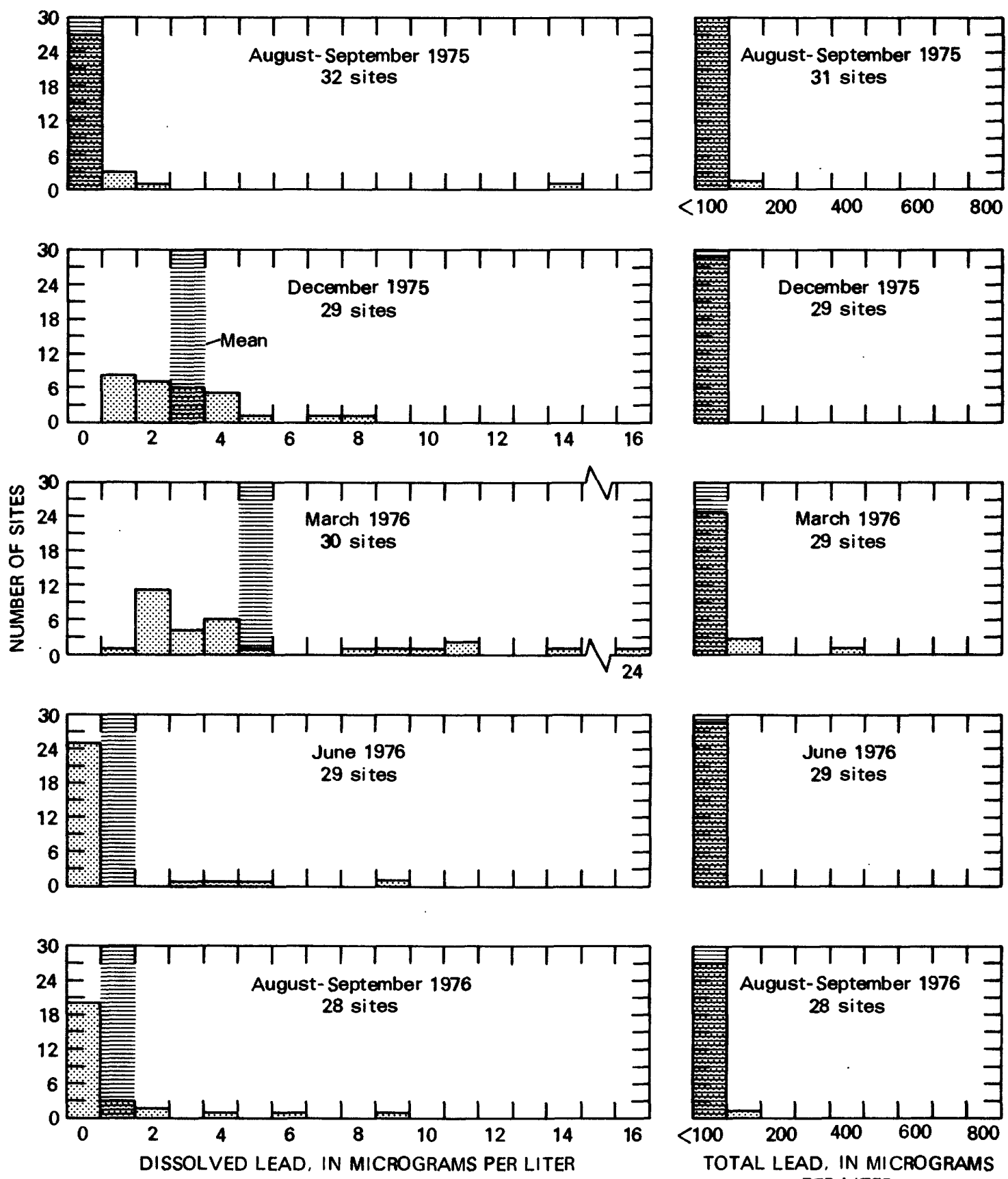

PER LITER

Figure 58.-- Frequency distributions of dissolved and total lead in streams of the Yampa River basin, August-September 1975 through August-September 1976. 

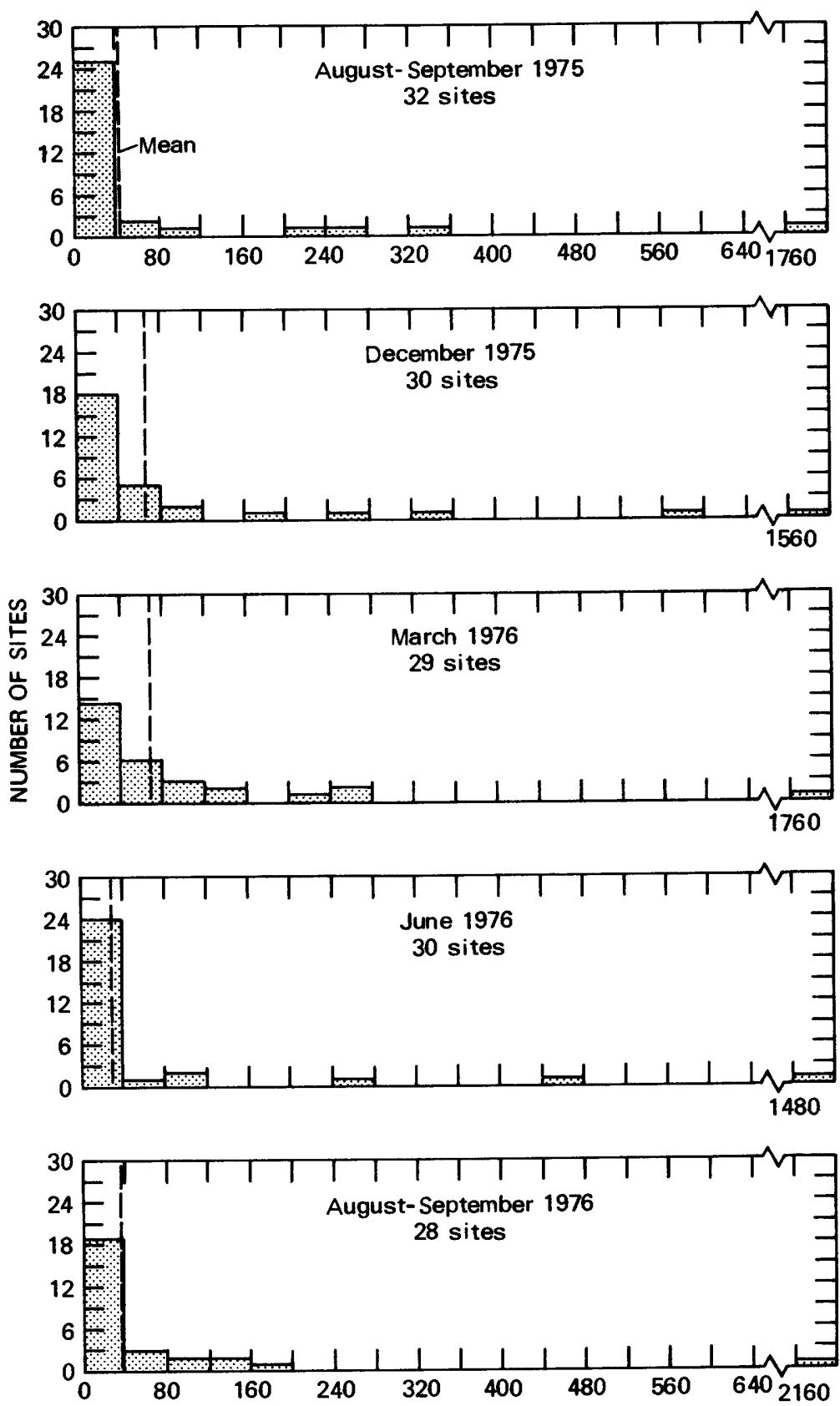

DISSOLVED MANGANESE, IN MICROGRAMS PER LITER

Figure 59.-- Frequency distributions of dis solved manganese in streams of the Yampa River basin, August-September 1975 through August-September 1976. 


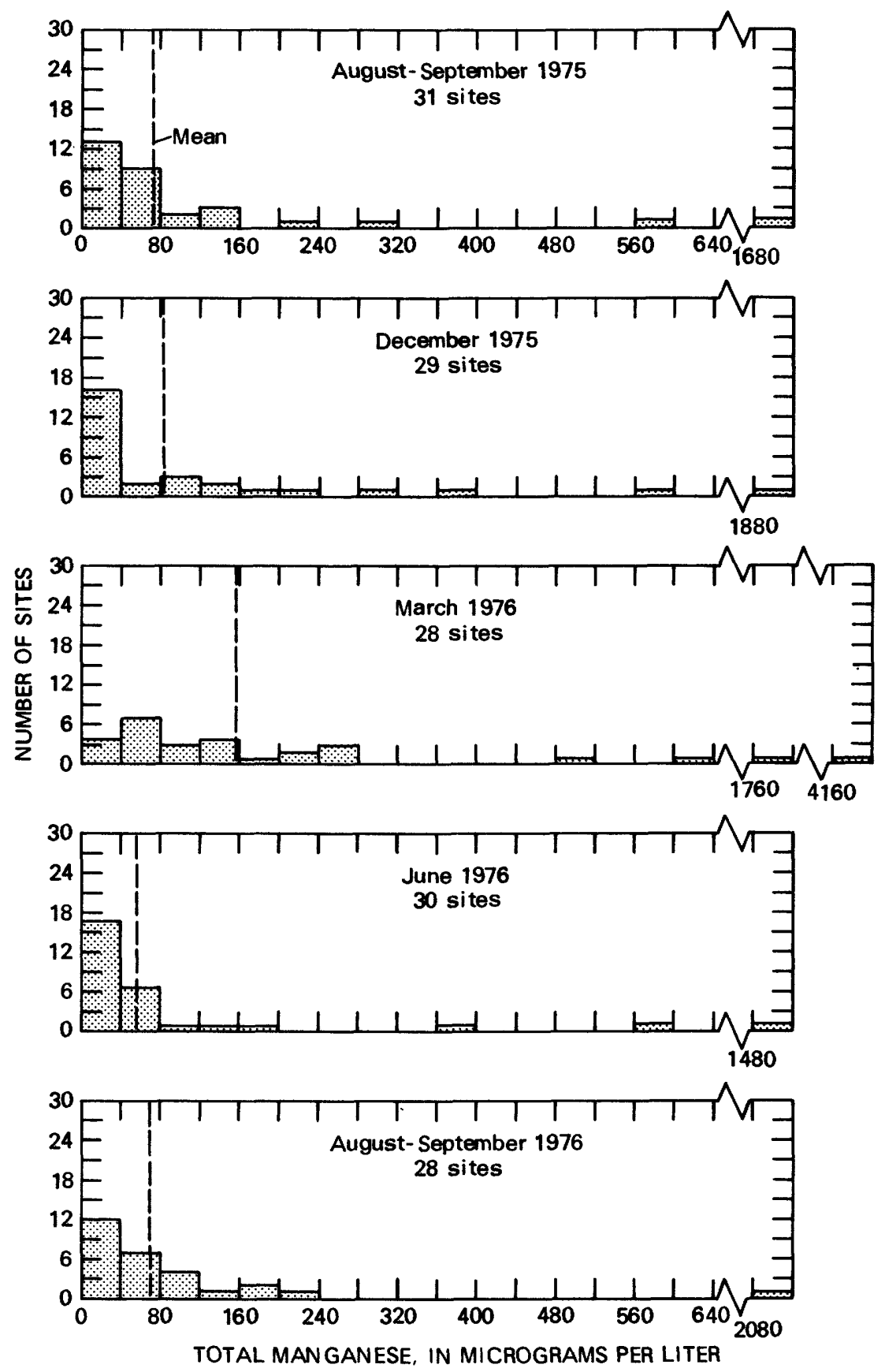

Figure 60.-- Frequency distributions of total manganese in streams of the Yampa River basin, August-September 1975 through August-September 1976. 

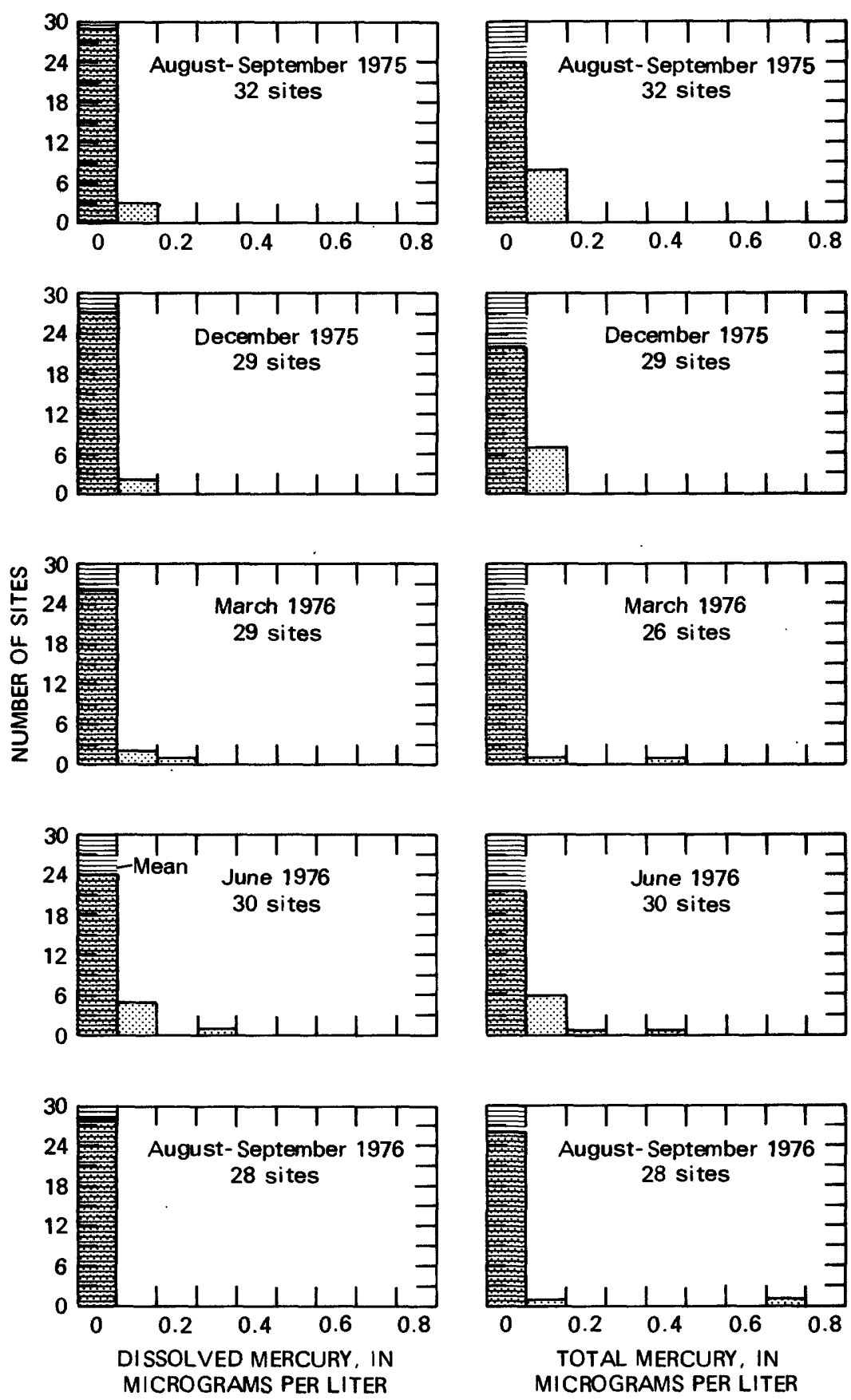

Figure 61.-- Frequency distributions of dissolved and total mercury in stream s of the Yampa River basin, August-September 1975 through August-September 1976. 

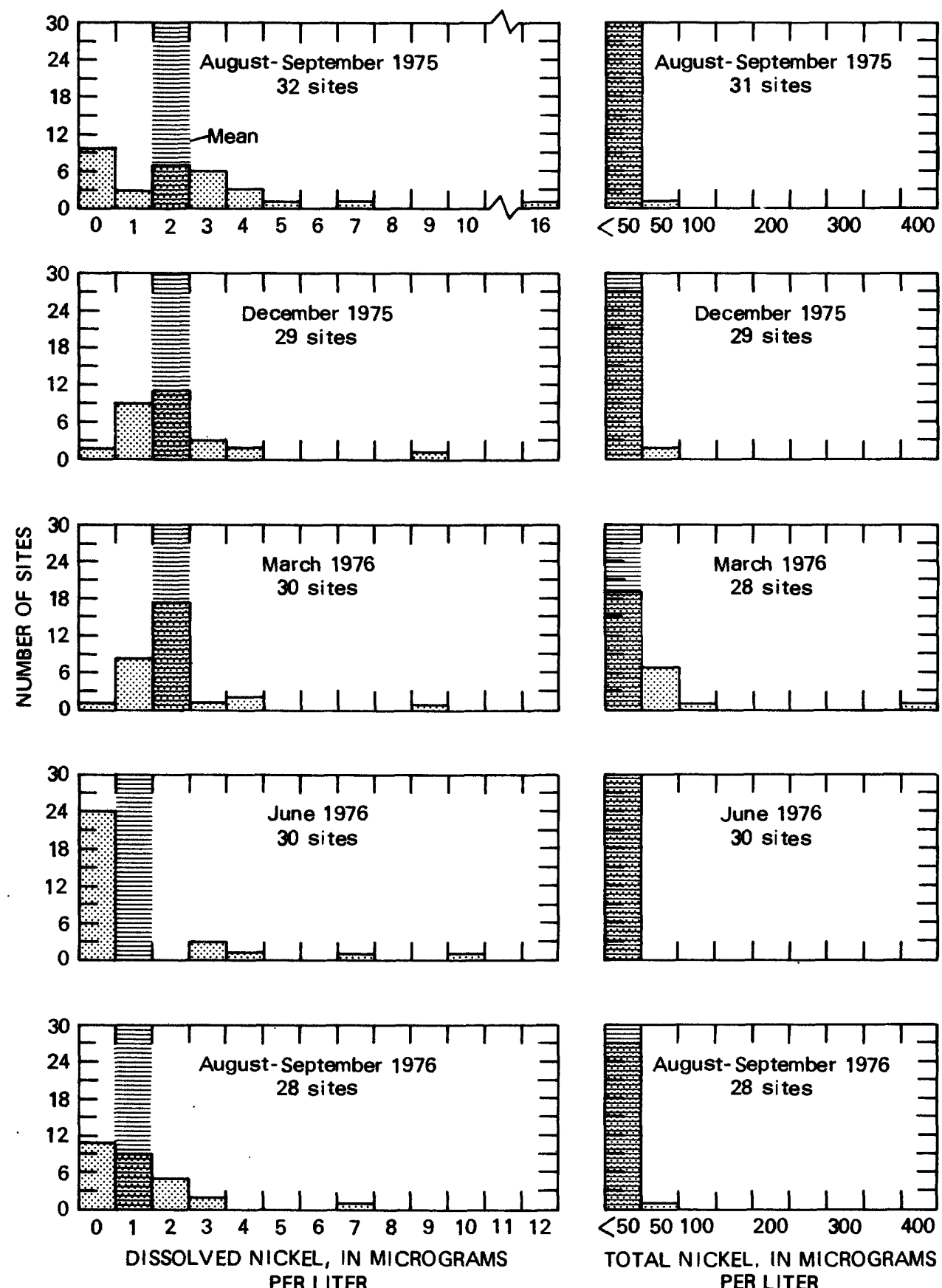

PER LITER

PER LITER

Figure 62.-- Frequency distributions of dissolved and total nickel in streams of the Yampa River basin, August-September 1975 through August-September 1976. 

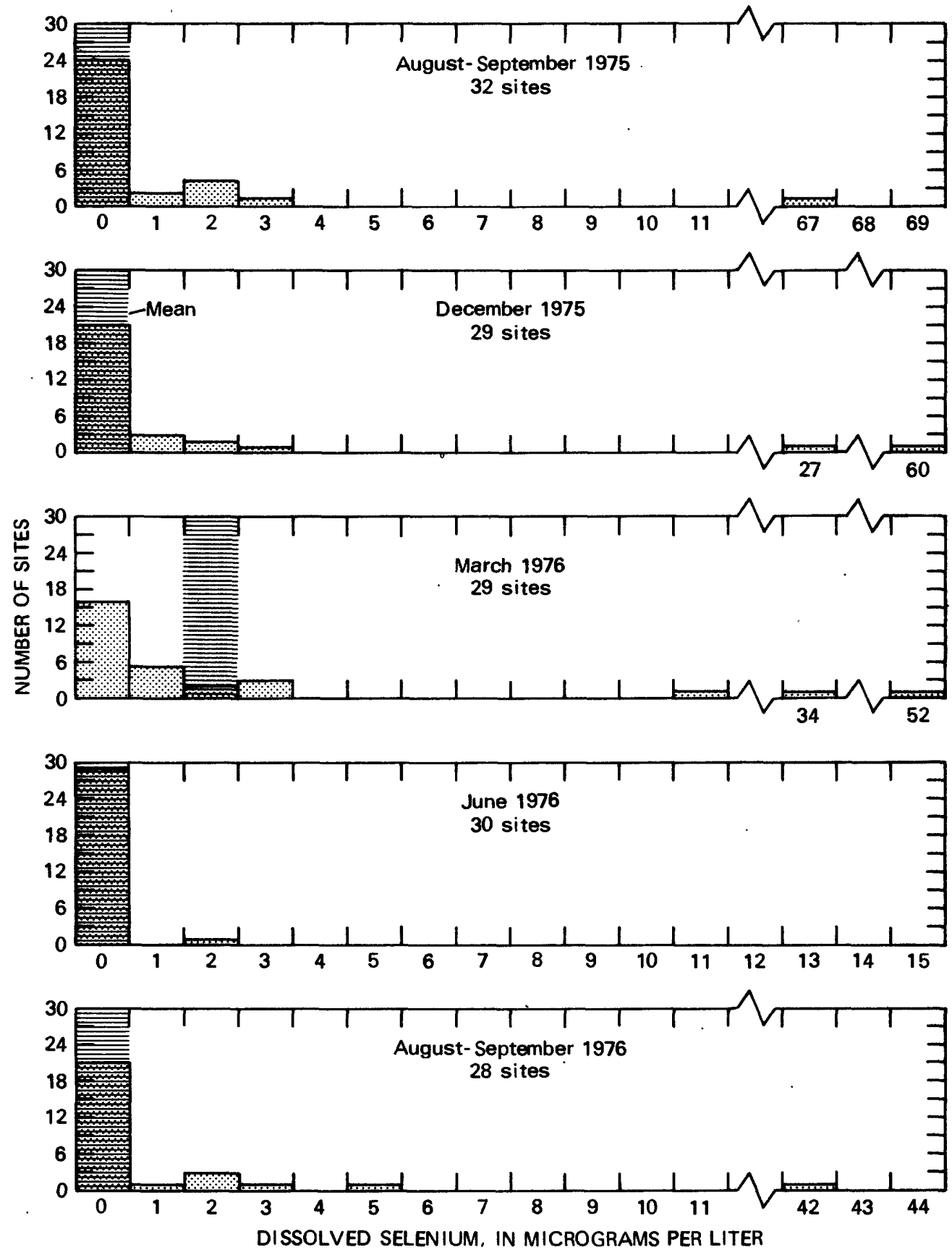

Figure 63.- Frequency distributions of dissolved selenium in stream $s$ of the Yampa River basin, August-September 1975 through AugustSeptember 1976. 

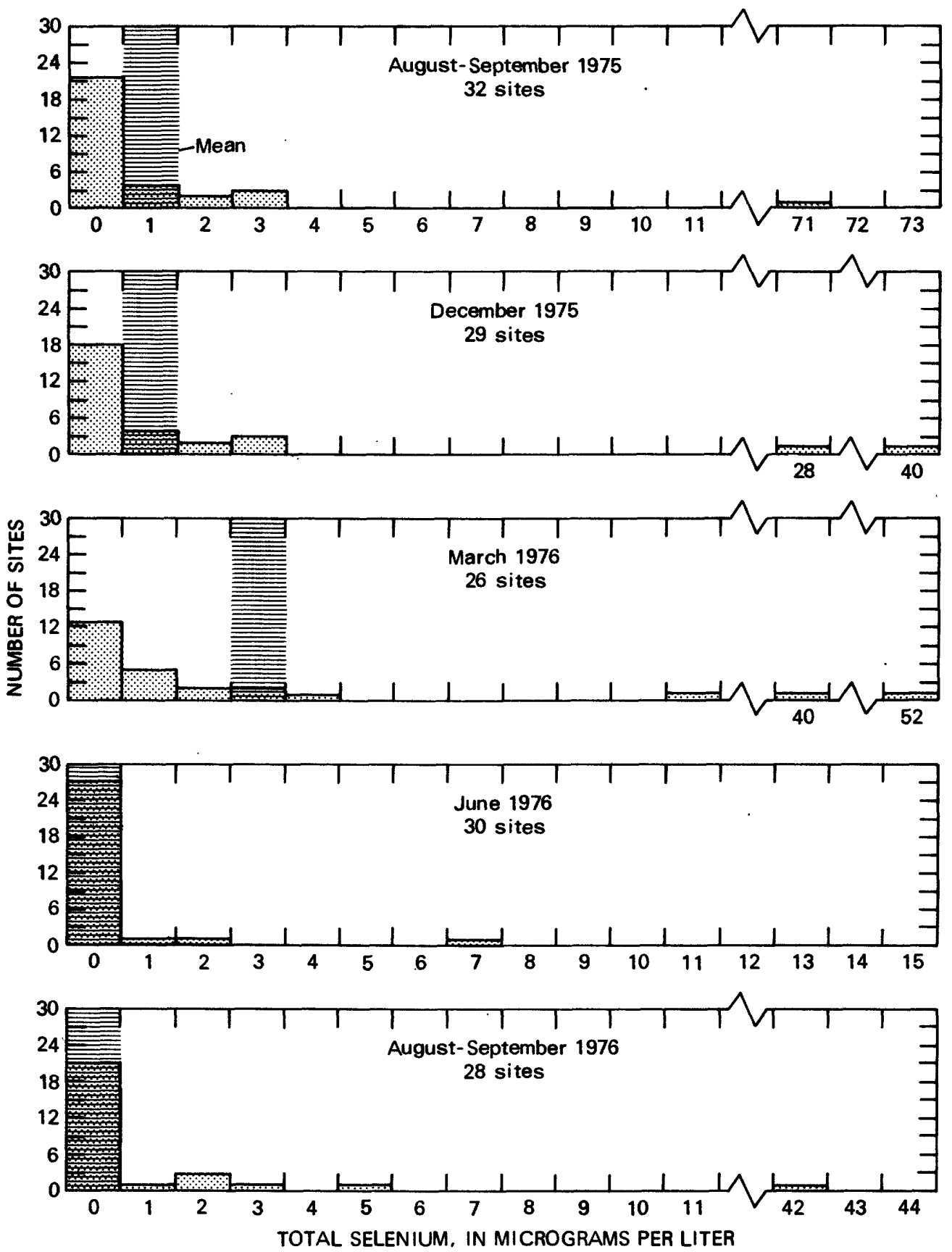

Figure 64.-- Frequency distributions of total selenium in streams of the Yampa River basin, August-September 1975 through August-September 1976. 

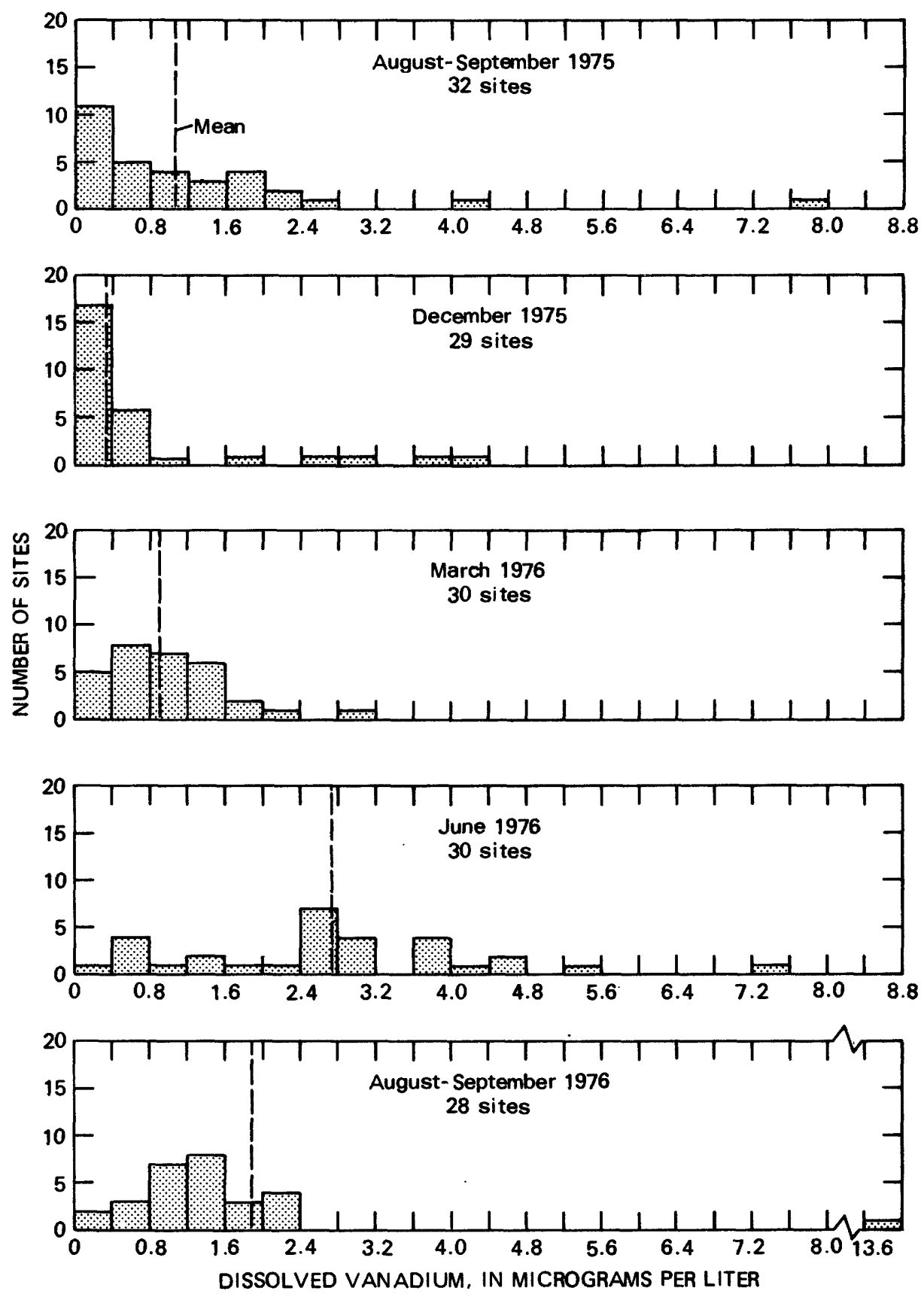

Figure 65.-- Frequency distributions of dissolved vanadium in streams of the Yampa River basin, August-September 1975 through AugustSeptember 1976. 

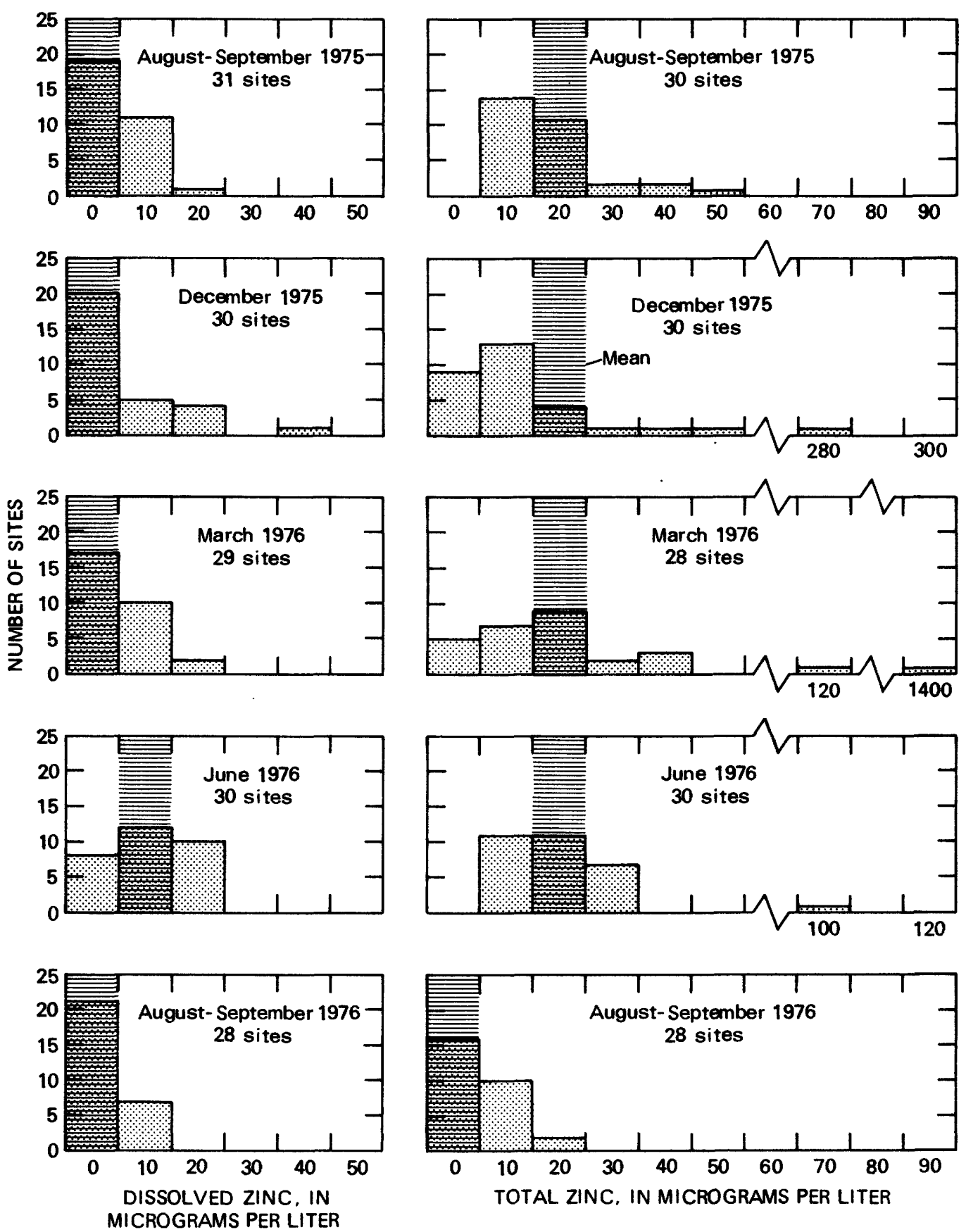

Figure 66.-- Frequency distributions of dissolved and total zinc in streams of the Yampa River basin, August-September 1975 through August-September 1976. 
Trace Elements in Stream-Bottom Sediments 

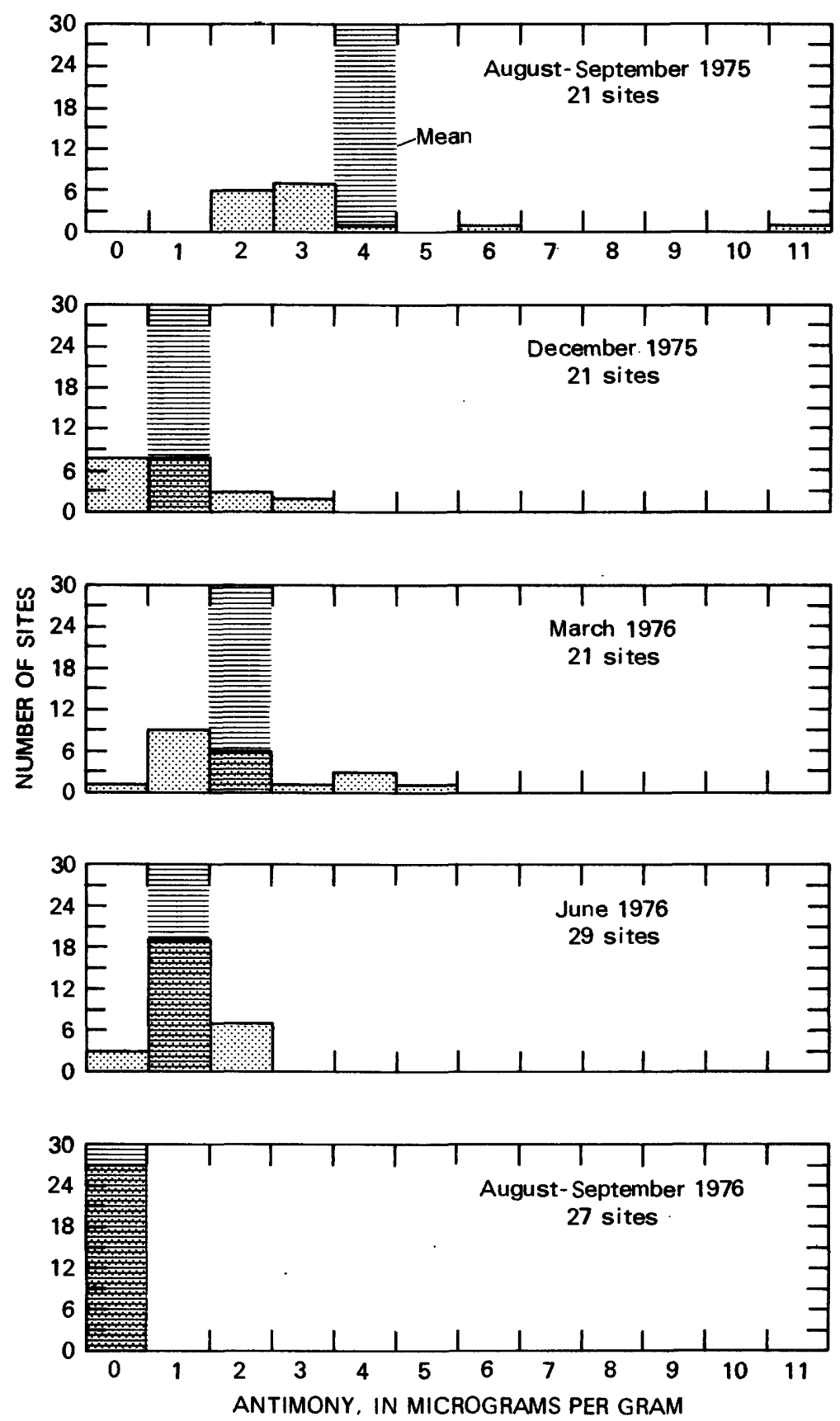

Figure 67.-- Frequency distributions of antimony in stream-bottom sediments of the Yampa River basin, August-September 1975 through August-September 1976. 

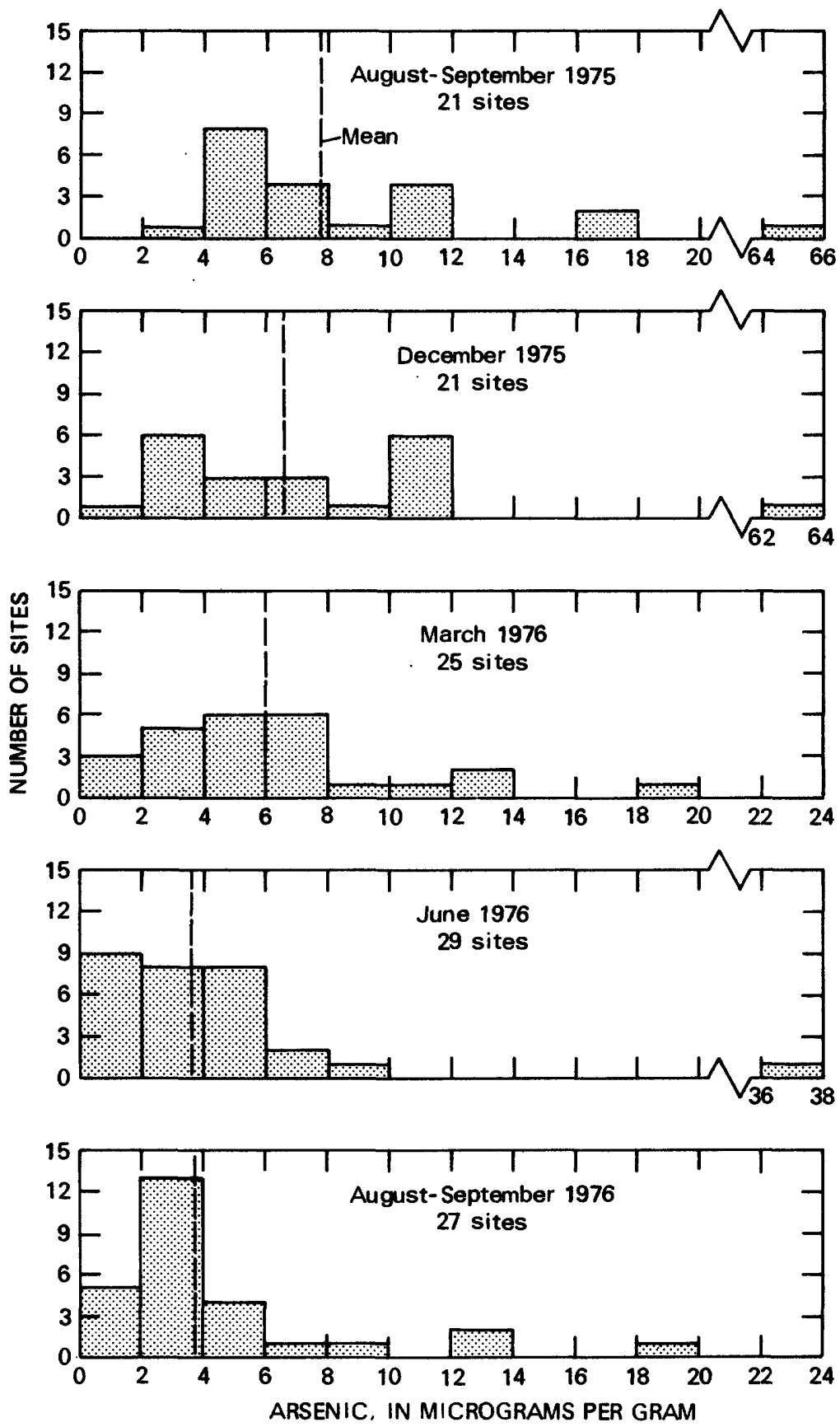

Figure 68.-- Frequency distributions of arsenic in stream-bottom sediments of the Yampa River basin, August-September 1975 through August-September 1976. 

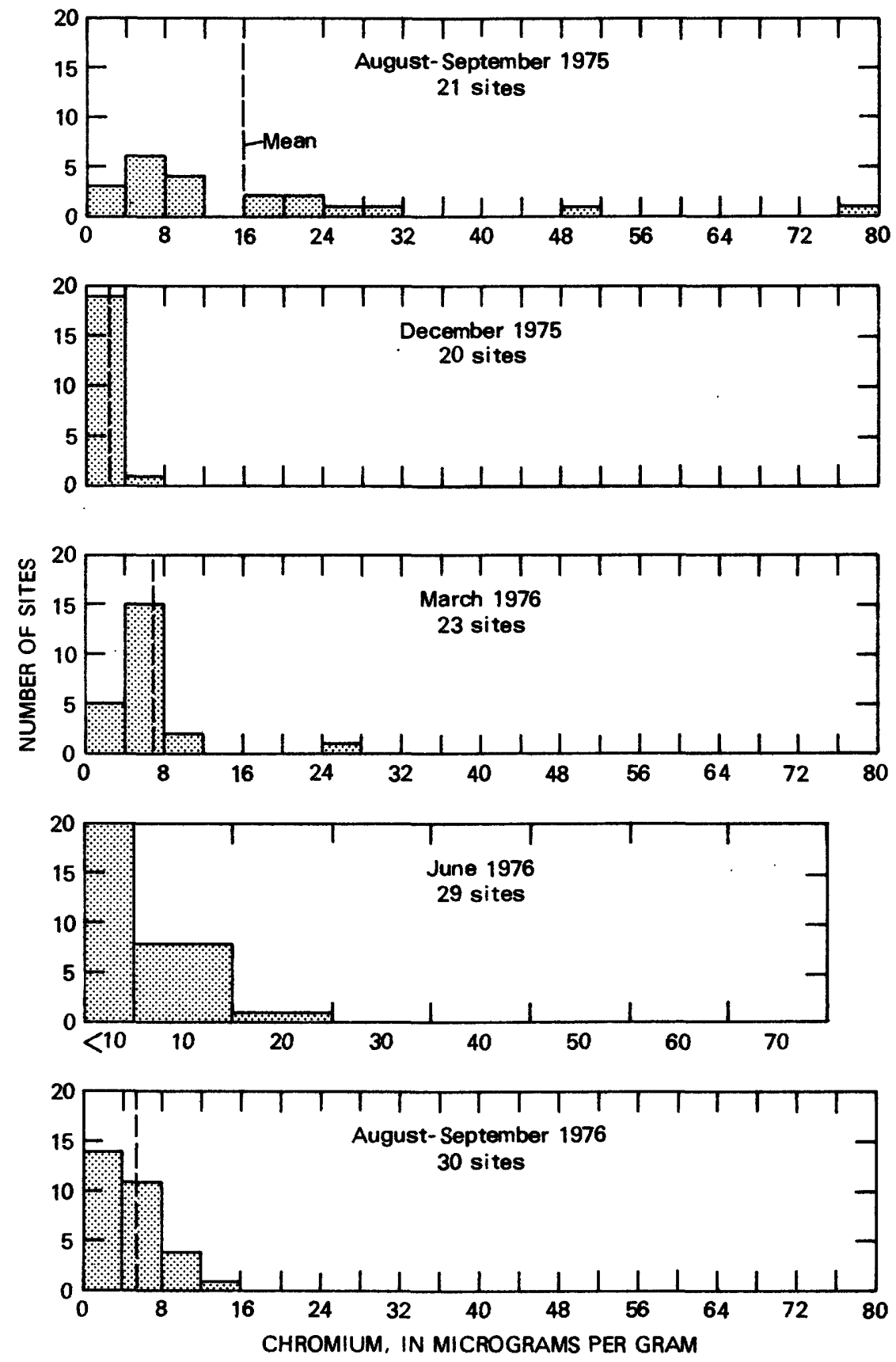

Figure 69.-- Frequency distributions of chromium in stream-bottom sediments of the Yampa River basin, August-September 1975 through August-September 1976. 

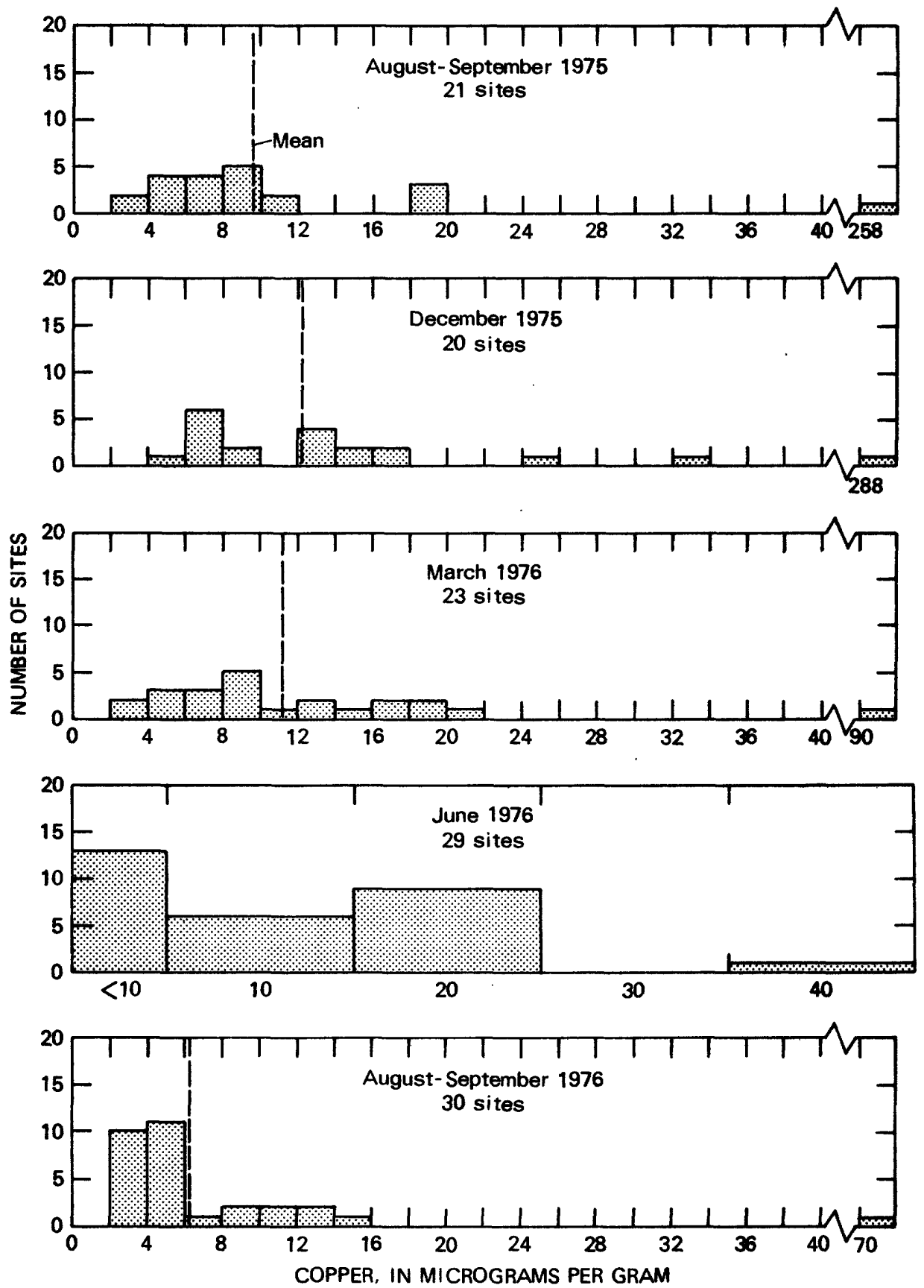

Figure 70.-- Frequency distributions of copper in stream-bottom sediments of the Yampa River basin, August-September 1975 through AugustSeptember 1976. 

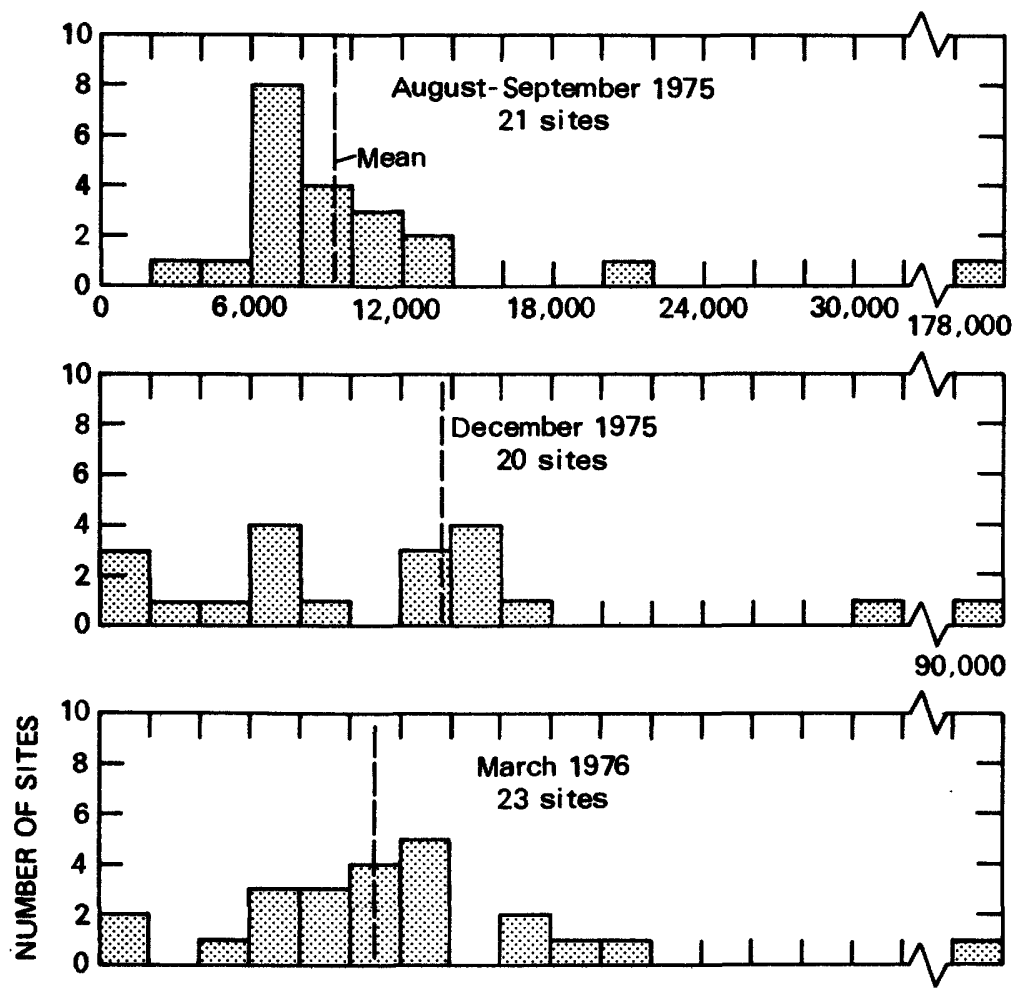

50,000
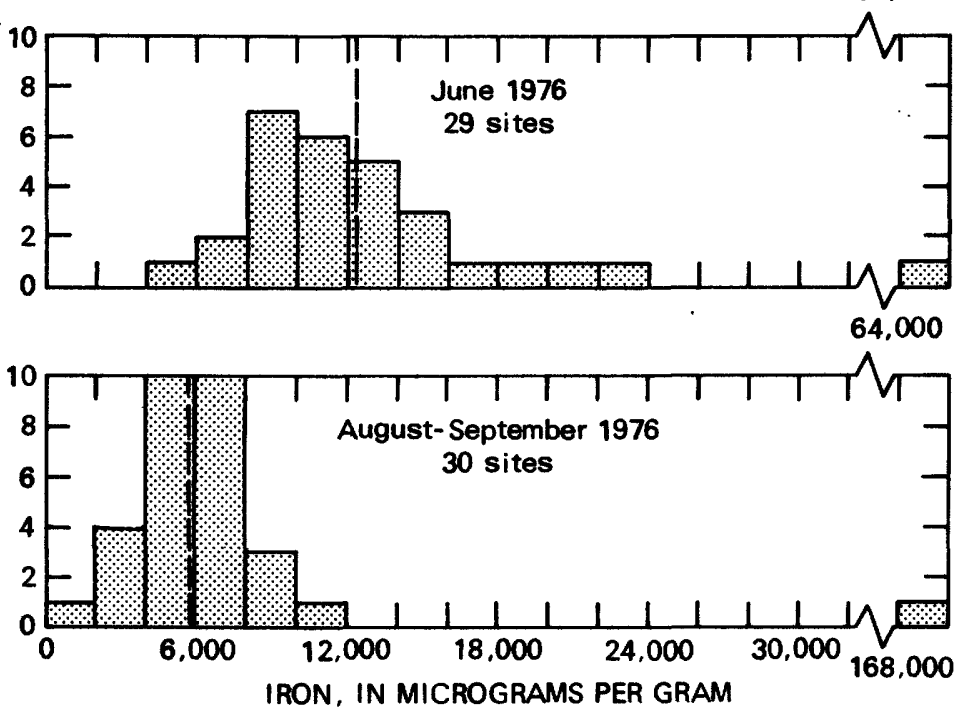

Figure 71.-- Frequency distributions of iron in stream-bottom sediments of the Yampa River basin, August-September 1975 through August-September 1976. 

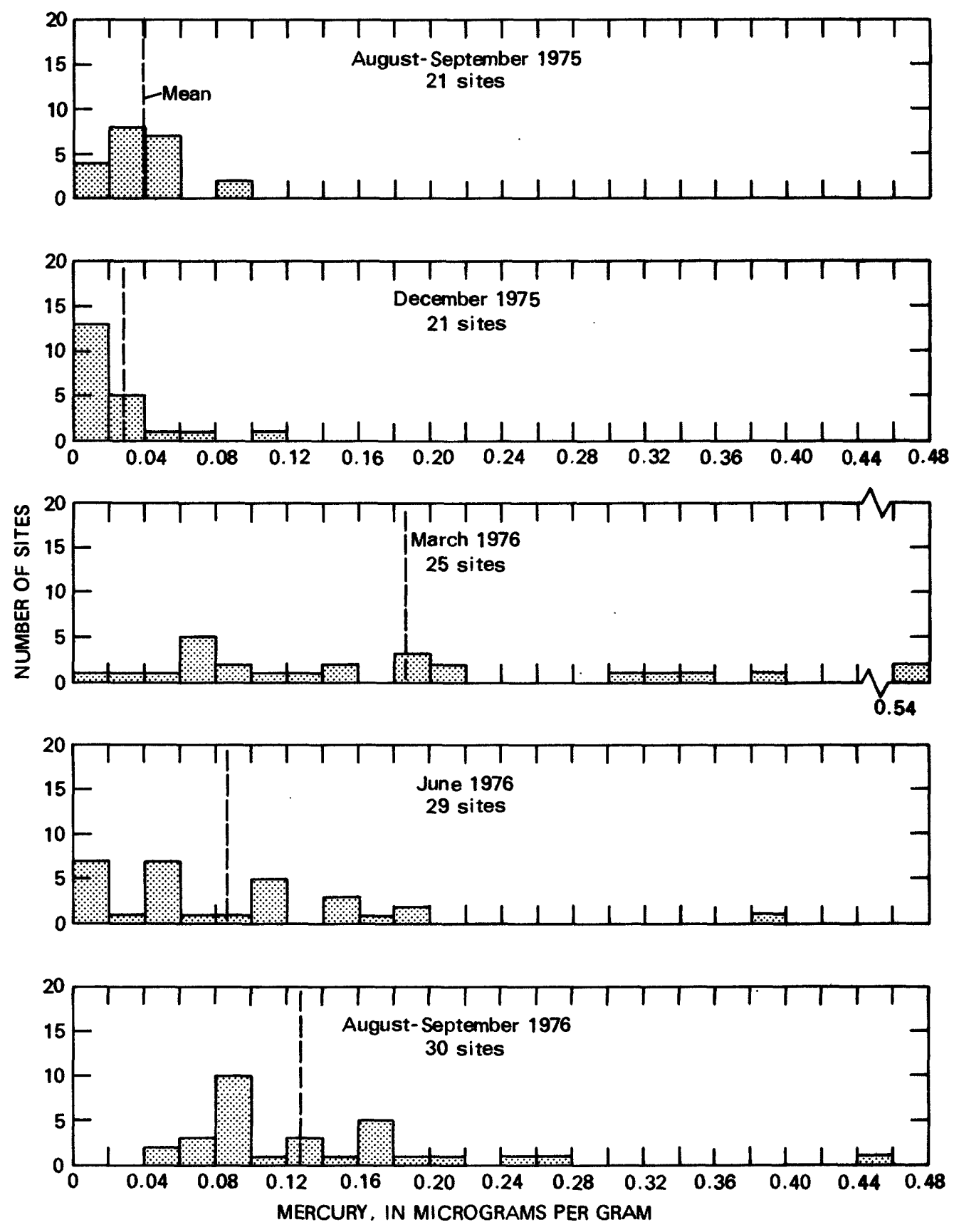

Figure 72.-- Frequency distribution s of mercury in stream-bottom sediments of the Yampa River basin, August-September 1975 through AugustSeptember 1976. 

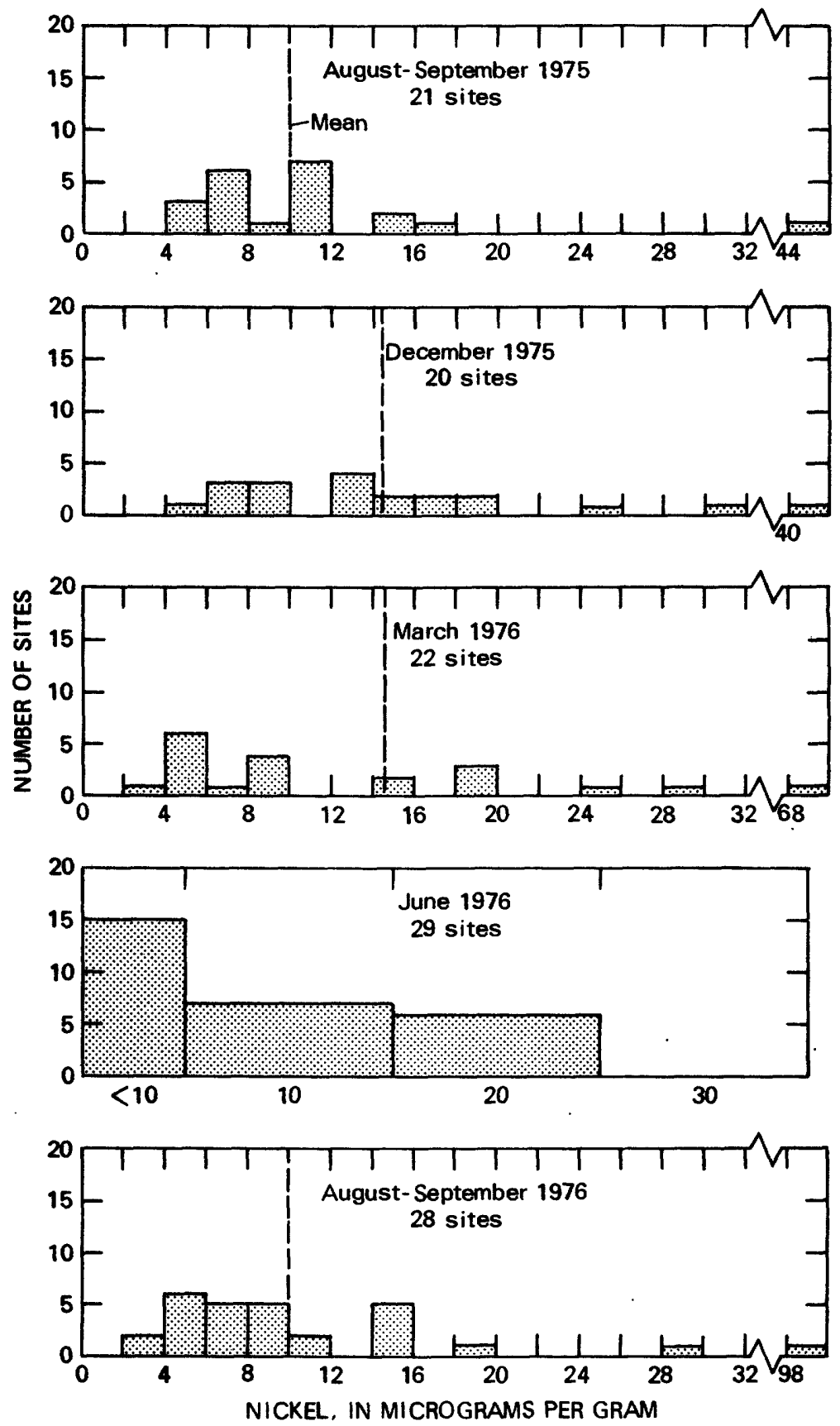

Figure 73.-- Frequency distributions of nickel in streambottom sediments of the Yampa River basin, AugustSeptember 1975 through August-September 1976. 
Nutrients 

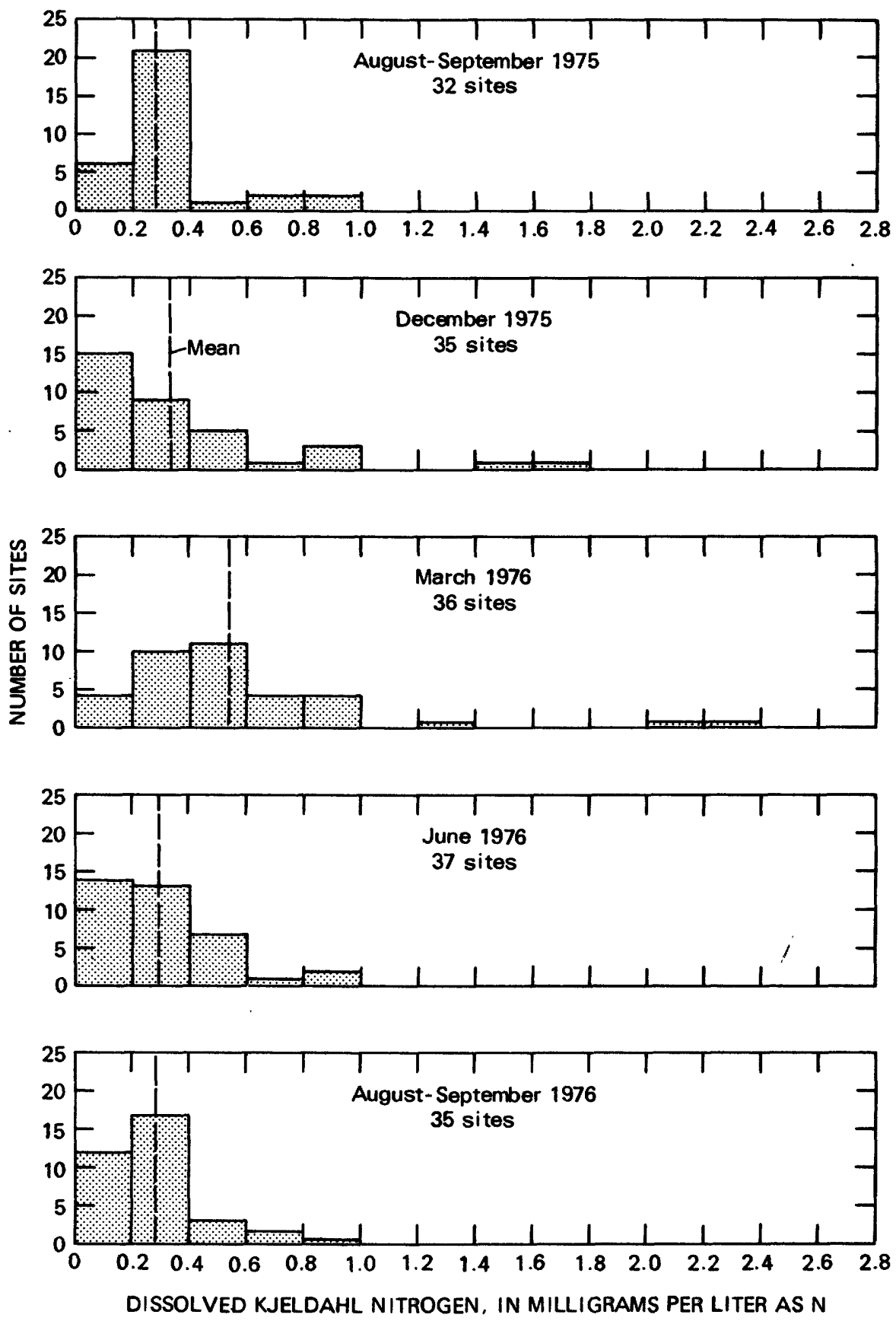

Figure 74.-- Frequency distributions of dissolved Kjeldahl nitrogen in stream s of the Yampa River basin, August-September 1975 through August- September 1976. 

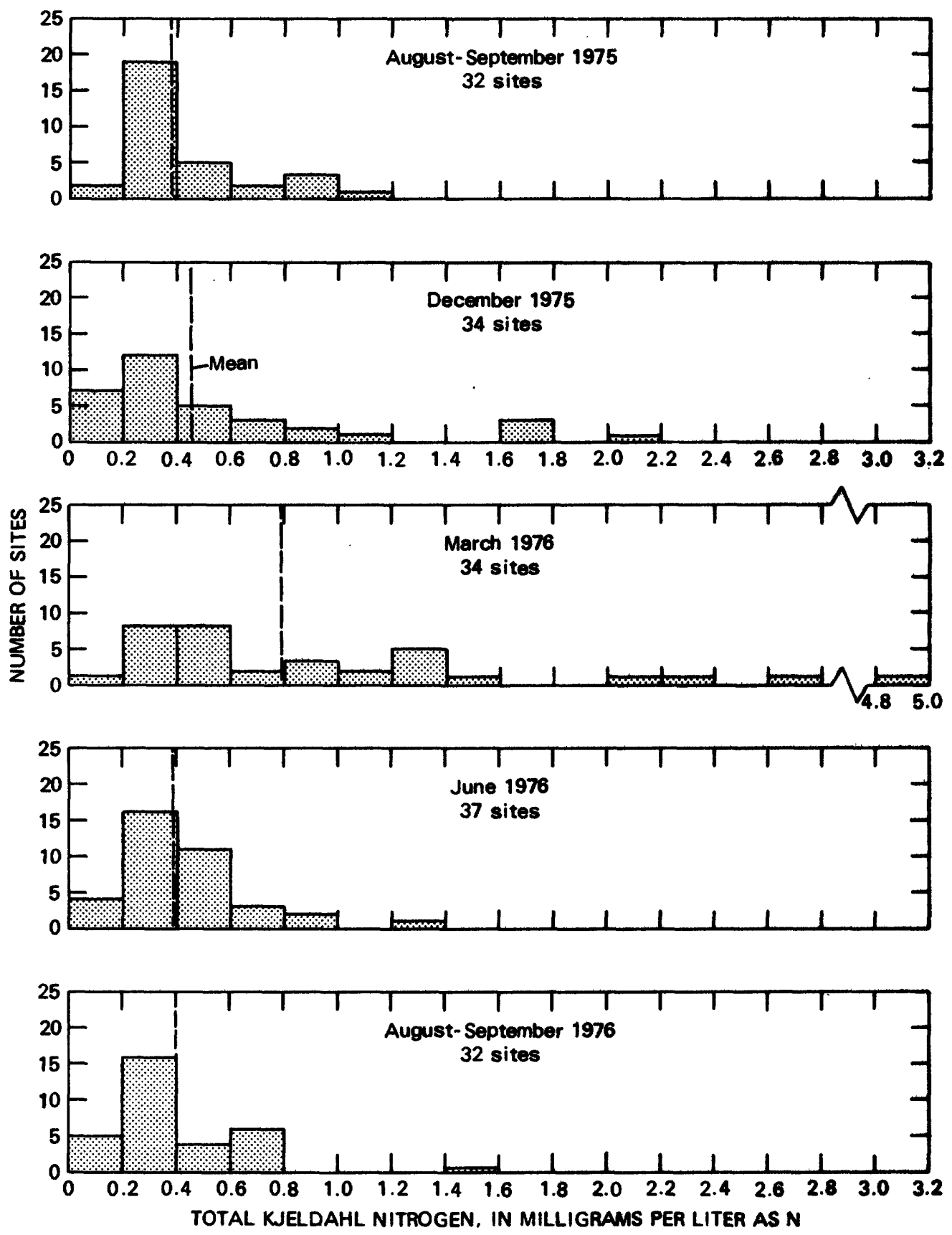

Figure 75.-- Frequency distributions of total Kjeldahl nitrogen in stream $\mathrm{s}$ of the Yampa River basin, August-September 1975 through AugustSeptember 1976. 

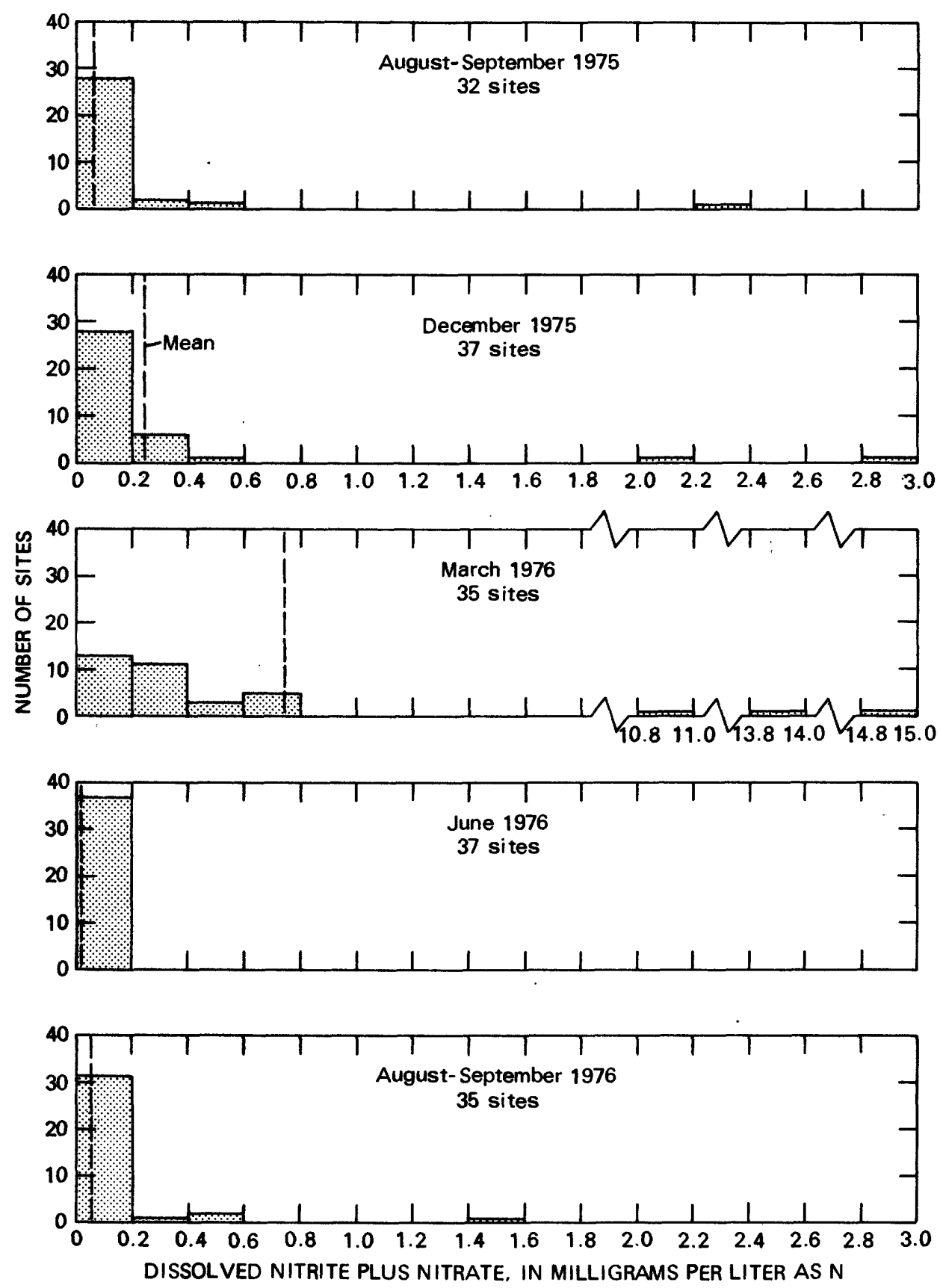

Figure 76.- Frequency distributions of dissolved nitrite plus nitrate in streams of the Yampa River basin, August-September 1975 through August-September 1976. 

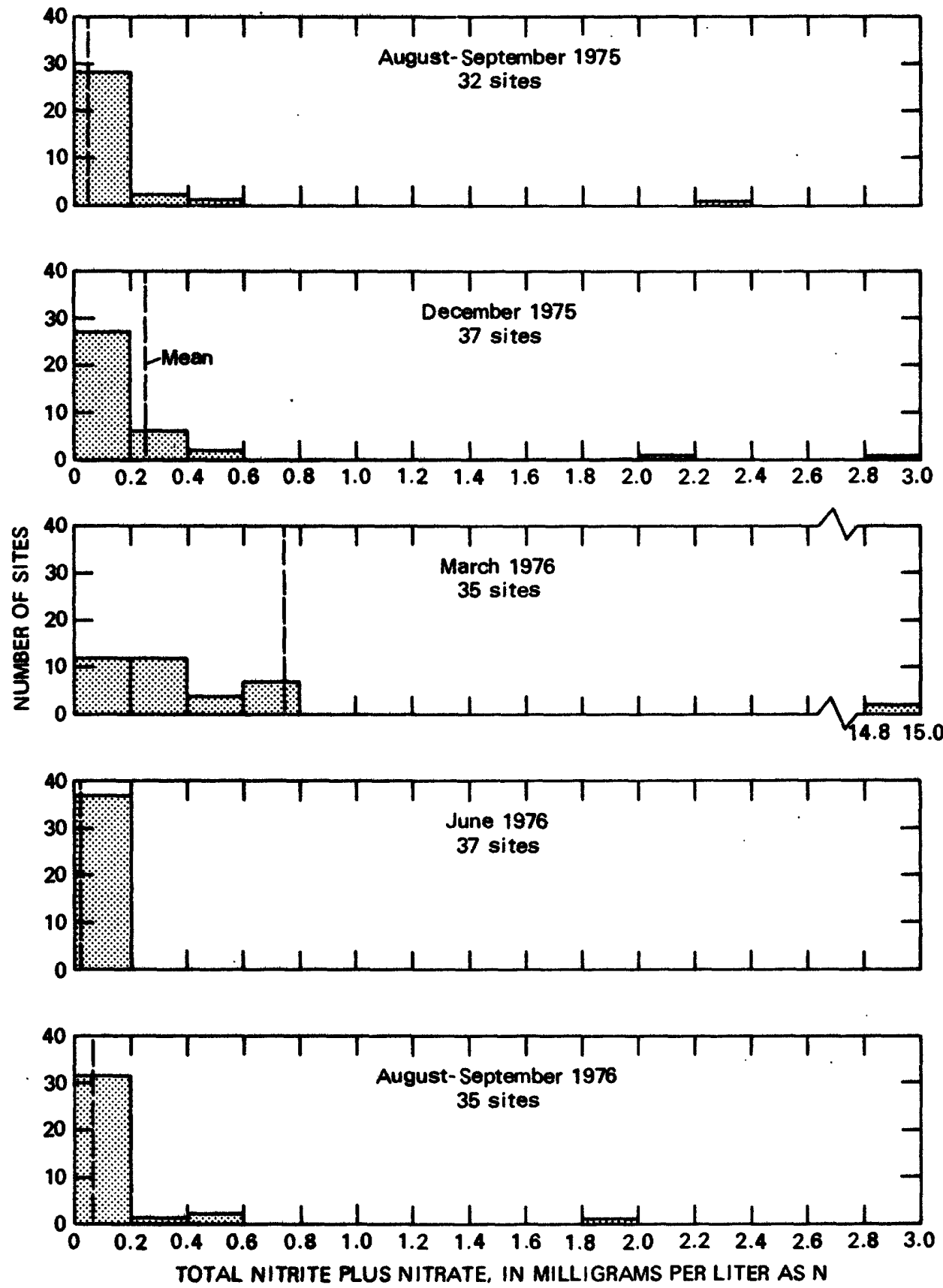

Figure 77.- Frequency distributions of total nitrite plus nitrate in streams of the Yampa River basin, August-September 1975 through Augu st-September 1976. 

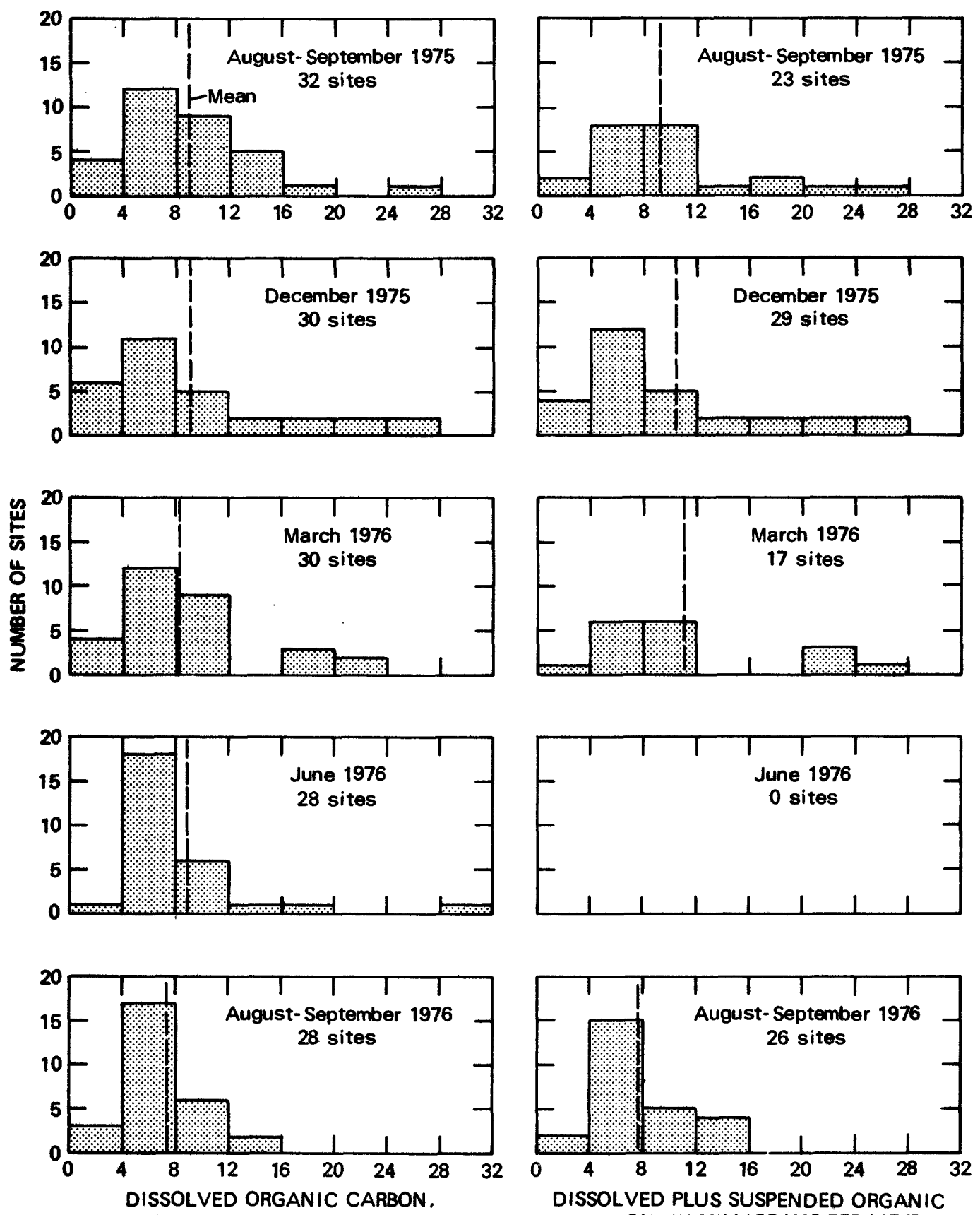

IN MILLIGRAMS PER LITER

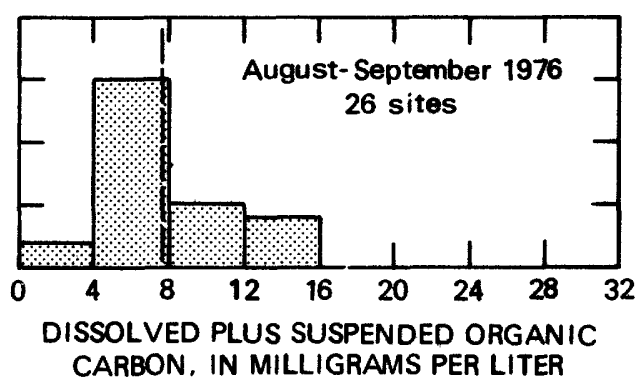

Figure 78.-- Frequency distributions of dissolved and dissolved plus suspended organic carbon in streams of the Yampa River basin, August-September 1975 through August-September 1976. 

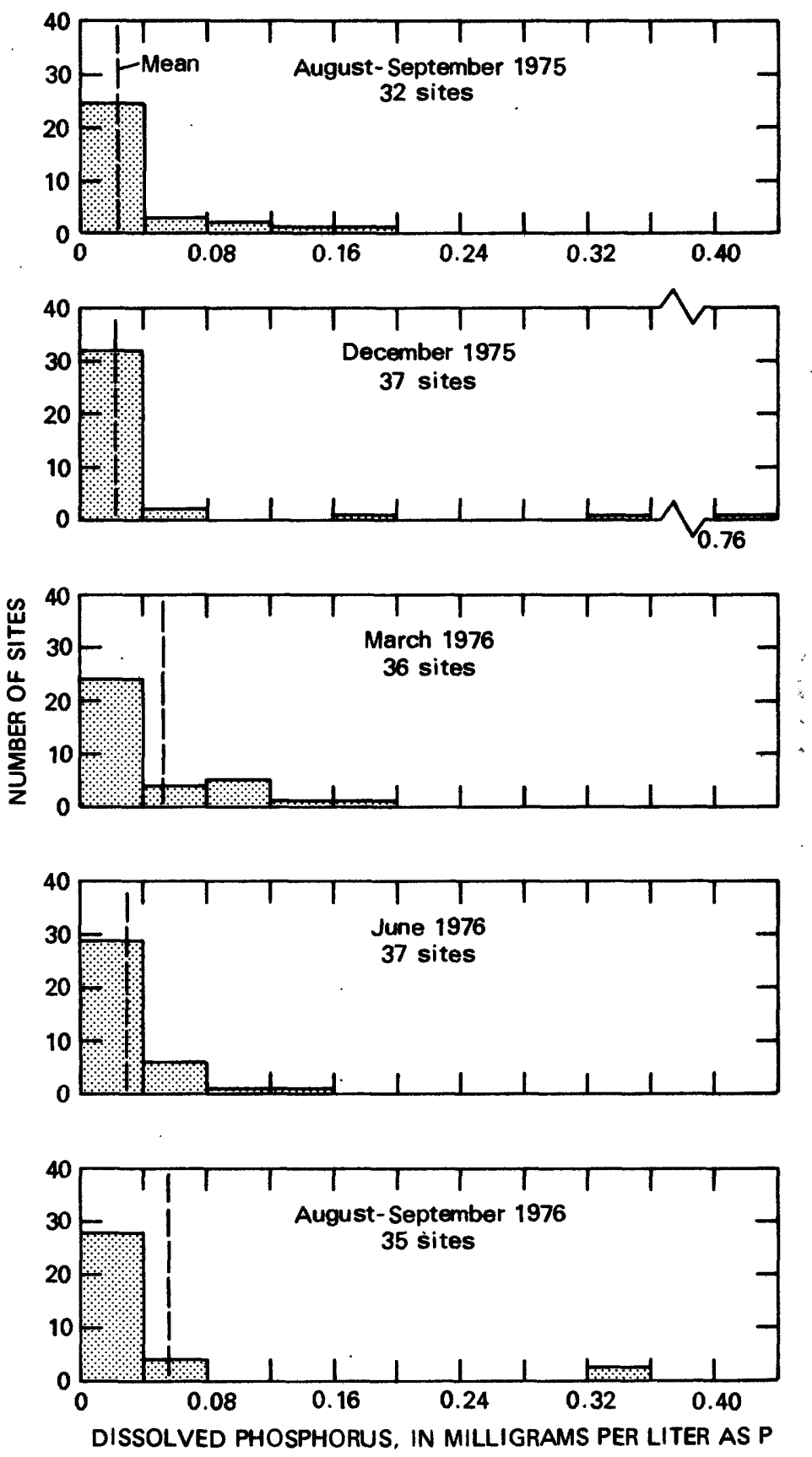

Figure 79.-- Frequency distributions of dissolved phosphorus in streams of the Yampa River basin, August-September 1975 through August-September 1976. 

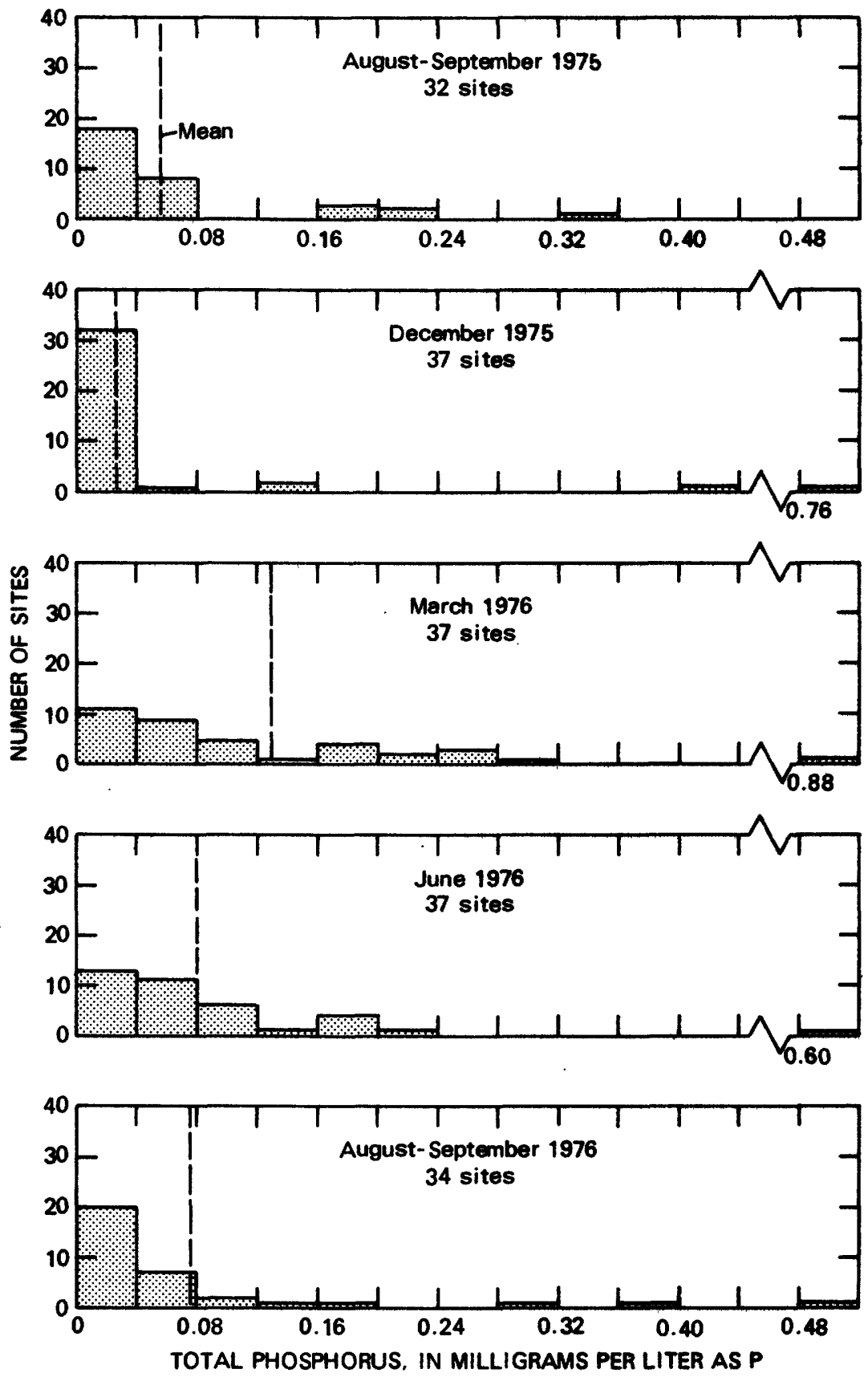

Figure 80.-- Frequency distributions of total phosphorus in stream s of the Yampa River basin, August-September 1975 through August-Septem ber 1976. 


\section{Calculation of Evaporative-Cooling Concentration Factor}

The evaporative-cooling concentration factor $(C F)$ for the Hayden Powerplant was calculated from the equation:

$$
C F=\frac{C_{\text {effluent }}}{C_{\text {intake }}},
$$

where the $C^{\prime} s$ are concentrations of the same nonreactive chemical constituent given in the same units. Calculations were based on dissolved constituents as follows:

\begin{tabular}{|c|c|}
\hline Constituent & $C F$ \\
\hline Calcium--- & 3.9 \\
\hline Magnes i um-- & 3.7 \\
\hline Nickel-1-n & 3.8 \\
\hline Potassium- & 3.8 \\
\hline
\end{tabular}

A fifth value of approximately 2.5 for $C F$ was determined using fluoride; however, because fluoride values are relatively low $(0.2$ to $0.5 \mathrm{mg} / \mathrm{L})$ and are reported to the nearest $0.1 \mathrm{mg} / \mathrm{L}$, a slight analytical error could easily produce a large error in the concentration factor.

Because the powerplant effluent was not sampled, effluent concentrations for use in equation 11 were calculated as follows:

$$
C_{\text {effluent }}=\frac{C_{46^{Q}} 46^{-C_{46 A^{Q}}} 46 A}{{ }_{46^{-Q_{46 A}}}},
$$

where $C_{46}$ and $C_{46}$ are the concentrations at sites $Y-46$ and $Y-46 \mathrm{~A}$, respectively, and $Q_{46}^{46 A}$ and $Q_{46}$ are the respective stream discharges. Concentrations of ${ }^{46}$ calcium, ${ }^{4}$ magnesium, potassium, and fluoride at site $\mathrm{Y}-46 \mathrm{~A}$ (upstream from the powerplant effluent) had to be approximated using the regression relationships given in table 8 , as analyses of these constituents were not available for this site. The dissolved nickel value and all values for $C_{46}$ (equation 12 ) and $C_{\text {intake }}$ (equation 11 ) were analytically determined. 


\section{.}

, 